\title{
JOURNAL of the MEXICAN
}
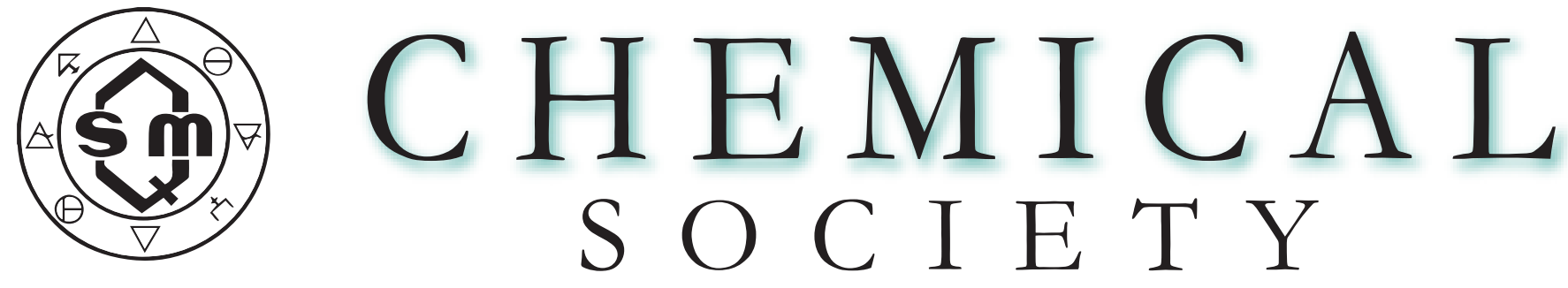

JANUARY - MARCH - 2017

(J. Mex. Chem.Soc.)

REVISTA de la SOCIEDAD QUIMICA de MÉXICO former

(Rev. Soc. Quím. Méx.)

J. Mex. Chem. Soc. 2017, 61(1)

Pages 1-73 Preprint

Quarterly publication

www.jmcs.org.mx

Mexico City 


\section{JOURNAL of the MEXICAN}
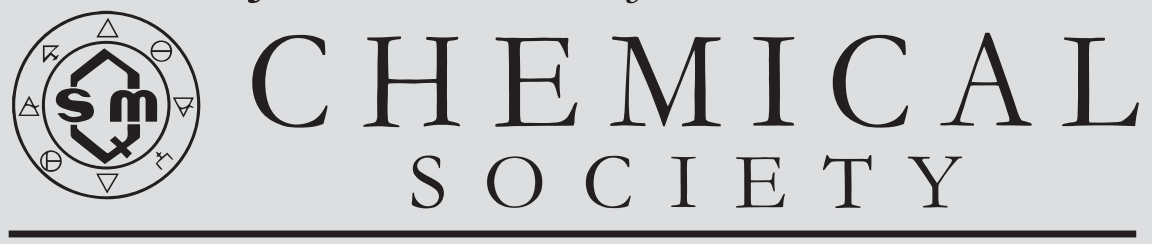

(J.Mex. Chem.Soc.)

The Journal of the Mexican Chemical Society (former Revista de la Sociedad Química de México) is a peer reviewed trimonthly journal which publishes original contributions and critical reviews in all areas of chemical sciences. It will publish fundamental work on physical, organic, inorganic, theoretical, analytical and biological chemistry, as well as aspects of supramolecular chemistry, electrochemistry, polymer chemistry, natural products chemistry, oil chemistry, organometallic chemistry, medical chemistry, biochemistry, chemical ecology, green chemistry, environmental chemistry, macromolecular chemistry, nuclear chemistry, chemistry of materials, and catalysis, among other topics. Full detailes on how to submit material to publication are given in Instructions for Authors on the printed journal, on the website: www.jmcs.org.mx or via e-mail to: editor. jmcs@gmail.com

\section{EDITORIAL BOARD 2016}

Ignacio González (Editor); igm@xanum.uam.mx

\section{Associated Editors}

Miguel Antonio Costas Basín; costasmi@unam.mx Gabriel Eduardo Cuevas González Bravo; gecgb@unam.mx Guillermo Delgado; delgado@unam.mx Bernando Frontana Uribe; bafrontu@unam.mx Annia Galano Jiménez; annia.galano@gmail.com Enrique Lima Muñoz; lima@iim.unam.mx Víctor Loyola Vargas; vmloyola@cicy.mx Antonio Martínez Richa; richa@ugto.mx Rachel Mata Essayag; rachel@unam.mx José L. Medina-Franco; jose.medina.franco@gmail.com Mercedes Teresita Oropeza-Guzmán; oropeza1@yahoo.com Gerko Oskam; oskam@cinvestav.mx Joaquín Tamaríz Mascarúa; jtamarizm@gmail.com Hugo Torrens Miquel; torrens@unam.mx Alberto Vela Amieva; avela@cinvestav.mx

Carlos Velazquez Martínez; velazque@ualberta.ca Margarita Viniegra Ramírez; mvr@xanum.uam.mx Katarzyna Wrobel; katarzyn@ugto.mx

Francisco Yuste López; yustef@unam.mx

\section{EDITORIAL ASSISTANCE}

Adriana Vázquez Aguirre; editor.jmcs@gmail.com

\section{ADVISORY EDITORIAL BOARD 2016}

Francisco Bolívar; bolivar@ibt.unam.mx Guillermina Burillo; burillo@nucleares.unam.mx Luis Echegoyen; luis@clemson.edu

Nikolaus H. Fischer; nfischer@advantexmail.net Eusebio Juaristi; juaristi@relaq.mx

Pedro Joseph Nathan; pjoseph@nathan.cinvestav.mx

Mario J. Molina; mmolina@mit.edu

Heinrich Nöth; H.Noeth@Irz.uni-muenchen.de

Keith Pannell; kpannell@utep.edu

Ratnasamy Somanathan; somanathan@sundown.sdsu.edu

\section{FORMER EDITORS}

José I. Bolívar Goyanes, Manuel Ulacia Esteve, Elvira Santos de Flores, Federico García Jiménez, Guillermo Delgado Lamas, Joaquín Tamariz Mascarúa, Juvencio Robles García

\section{TECHNICAL EDITOR}

Formas e Imágenes; formaseimagenes@gmail.com

\section{ISSN $1870-249 X$}

Journal of the Mexican Chemical Society (J. Mex. Chem. Soc.) Quarterly publication.

Editor-in-Chief: Ignacio González

Indexed Journal

Certificate of reserved rights granted by the Instituto Nacional del Derecho de Autor (INDAUTOR): 04-2005-052710530600-102

Certificate of lawful title and content: Under procedure

Postal registration of printed matter deposited by editors or agents granted by SEPOMEX: IM09-0312

Copyright (C) Sociedad Química de México, A.C. Total or partial reproduction is prohibited without written permission of the right holder.

The Figures/schemes quality and the general contents of this publication are full responsability of the authors.

Edited and distributed by Sociedad Química de México, A.C.

Barranca del Muerto 26, Col. Crédito Constructor, Del. Benito Juárez, C.P. 03940, Mexico City. Phone: +5255 56626837; +5255 56626823 Contact: soquimex@sqm.org.mx http://www.sqm.org.mx

Technical Editor: Formas e Imágenes, Av. Universidad 1953, Edif. 2 local E, Col. Copilco el Bajo, México, D.F.

Phone: +5255 55501784; +525556167117 Contact: formaseimagenes@gmail.com 


\section{JOURNAL of the MEXICAN}
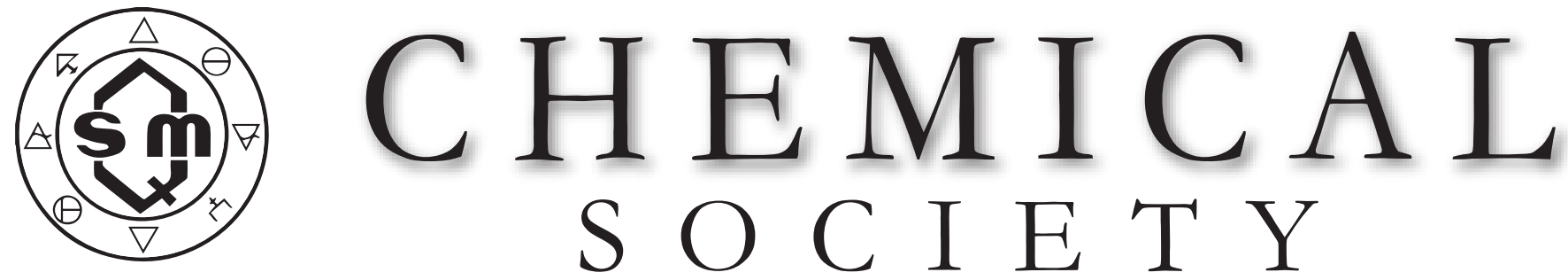

\section{$\mathrm{S} O \mathrm{C}$ I E T Y}

JANUARY - MARCH - 2017

(J.Mex. Chem.Soc.)

REVISTA de la SOCIEDAD QUÍMICA de MÉXICO 
Sociedad Química de México, A.C.

Barranca del Muerto 26,

Col. Crédito Constructor,

Del. Benito Juárez, C.P. 03940, Mexico City.

Phone: $+525556626837 ;+525556626823$

Contact: soquimex@sqm.org.mx

http://www.sqm.org.mx

The Sociedad Quimica de México was founded in 1956 as a non-profit association to promote the development of the professionals and students of chemistry in education, research, services and industry, and for the diffusion of chemical knowledge. The Sociedad Quimica de México organizes annually the Mexican Congress of Chemistry and the National Congress of Chemical Education, both congresses include activities of current interest for professionals and students of the chemical sciences. It grants annually the "Andrés Manuel del Río" National Award of Chemistry in the Academic area (field of research and field of education) and in the Technological area (field of technological development). It also grants each year the Rafael Illescas Frisbie Best Bachelor, Master and Doctoral Thesis in Chemical Sciences Awards and the biennial Award of the Sociedad Quimica de México in honor of the Doctor Mario J. Molina, directed to the professionals in Chemistry Sciences.

The Journal of the Mexican Chemical Society (J.Mex. Chem. Soc) is the official journal of the Sociedad Química de México, it was published as Revista de la Sociedad Química de México (Rev. Soc. Quím. Mex.) from 1957 to 2003, changing its name in 2004. The Journal of the Mexican Chemical Society is a quarterly publication, devoted to the advancement of the understanding of chemistry by means of publication of research papers and critical reviews; the instructions for authors appear in each issue. The Sociedad Química de México also publishes since 2007 articles of general interest in the Boletin de la Sociedad Química de México.

La Sociedad Química de México fue fundada en 1956 como una agrupación sin fines de lucro para promover el desarrollo de los profesionales y estudiantes de la química en las áreas educativa, investigación, servicios e industria, y para difundir el conocimiento de la química. La Sociedad Química de México organiza anualmente el Congreso Mexicano de Química y el Congreso Nacional de Educación Química, en los cuales se desarrollan diversas actividades de interés para los profesionales y estudiantes de las ciencias químicas. Asimismo, otorga anualmente el Premio Nacional de Química "Andrés Manuel del Río" en el área Académica (campos de docencia e investigación) y en el área Tecnológica (campo de Desarrollo Tecnológico). También otorga anualmente el Premio a las Mejores Tesis de Licenciatura, Maestría y Doctorado en Ciencias Quimicas, Rafael Illescas Frisbie. De manera bienal otorga el Premio de la Sociedad Química de México en Honor al Doctor Mario J. Molina, dirigido a los profesionistas de las Ciencias Químicas.

El Journal of the Mexican Chemical Society (J.Mex. Chem. Soc.), es la revista oficial de la Sociedad Quimica de México. Desde 1957 y hasta 2003 fue publicada como Revista de la Sociedad Química de México (Rev. Soc. Quím. Mex.), cambiando su nombre en 2004. Es una publicación trimestral que tiene como objetivo coadyuvar al avance del entendimiento de la química; las instrucciones para los autores aparecen en cada fascículo. La Sociedad Química de México también publica desde 2007 artículos de interés general en el Boletín de la Sociedad Química de México.
Journal of the Mexican Chemical Society

(J. Mex. Chem. Soc.)

ISSN $1870-249 X$

former

Revista de la Sociedad Química de México

(Rev. Soc. Quim. Mex.)

ISSN 0583-7693

Journal of the Mexican Chemical Society (J. Mex. Chem. Soc.)

Quarterly publication.

Editor-in-Chief: Ignacio González

Indexed Journal

Certificate of reserved rights granted by the Instituto Nacional del Derecho de Autor (INDAUTOR): 04-2005-052710530600-102

Certificate of lawful title and content: Under procedure

Postal registration of printed matter deposited by editors or agents granted by SEPOMEX: IM09-0312

Copyright (C) Sociedad Química de México, A.C.

Total or partial reproduction is prohibited without written permission of the right holder.

The Figures/schemes quality and the general contents of this publication are full responsability of the authors.

Edited and distributed by Sociedad Química de México, A.C.

Barranca del Muerto 26, Col. Crédito Constructor,

Del. Benito Juárez, C.P. 03940, Mexico City.

Phone: $+525556626837 ;+525556626823$

Contact: soquimex@sqm.org.mx http://www.sqm.org.mx

Technical Editor Formas e Imágenes, S.A. de C.V.

Av. Universidad 1953, 2-E, Col. Copilco el Bajo, Coyoacán, Mexico City

Phone: +5255 55501784; +5255 56167117

Contact: formaseimagenes@gmail.com 


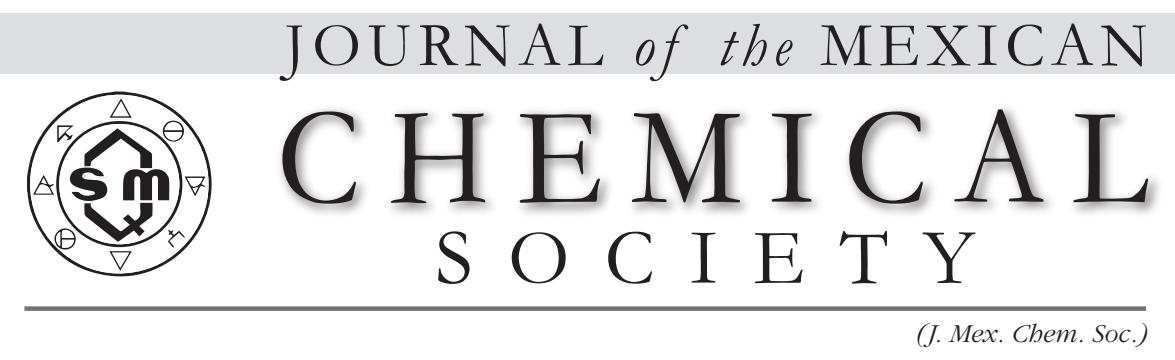

\section{Table of Contents}

\section{Articles}

1-13 Cluster modeling and coordination structures of $\mathrm{Cu}^{+}$ ions in Al-incorporated $\mathrm{Cu}$-MEL catalysts - a density functional theory study

Mehdi Ghambarian, Zahra Azizi,

and Mohammad Ghashghaee*

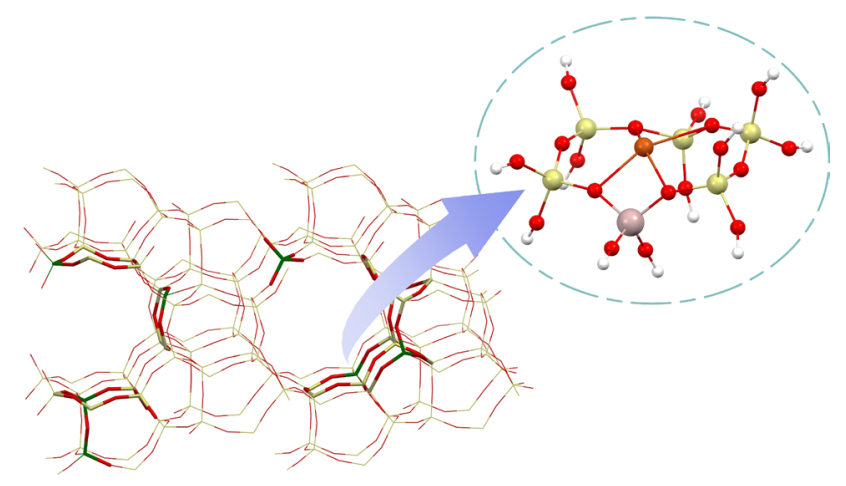

14-22 Policy Proposal for Metals Speciation in Tailings Contaminated Soils: A Case Study in Chihuahua, Mexico

Irma Cruz Gavilán García, * Georgina Fernández Villagómez, Alejandro Menchaca Pérez, Luis Adrian Barraza Torres and Arturo Gavilán García

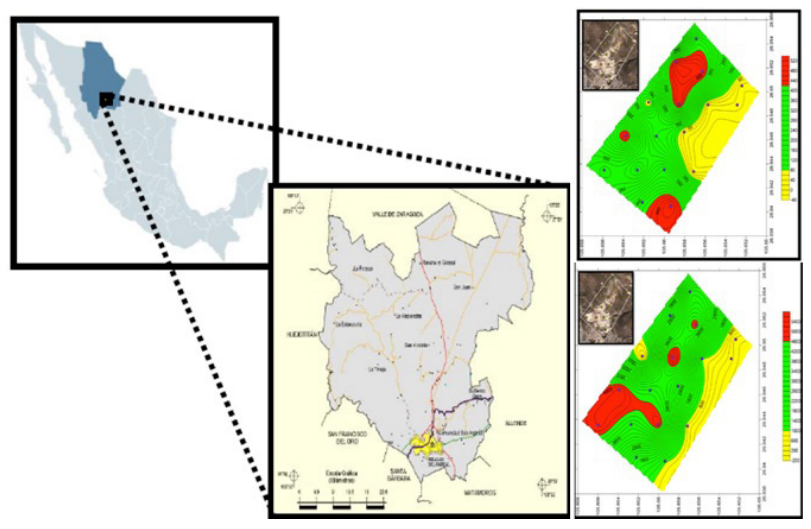

23-27 General Method for Selective Mono-Boc Protection of Diamines and Thereof

Felipe Antonio Servín, José Alfonso Romero, Gerardo Aguirre, Douglas Grotjahn, Ratnasamy Somanathan, and Daniel Chávez*

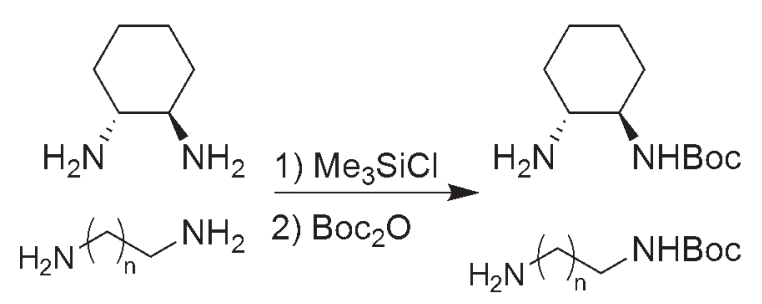

* The asterisk indicates the name of the author to whom inquiries about the paper should be addressed. 


\section{Table of Cont e n t s}

28-34 Nano $\mathrm{Fe}_{3} \mathrm{O}_{4}$ as Green Catalyst for Beckmann

Rearrangement under Ultrasound Irradiation

Mostafa KarimKoshteh* and Marziyeh Bagheri

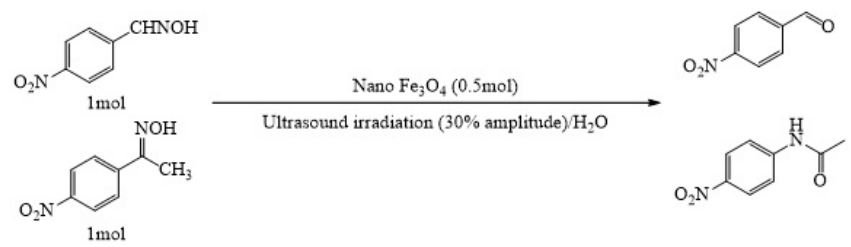

35-40 Fast and Green Method to Synthesis of Quinolone

Carboxylic Acid Derivatives Using Giant-Ball

Nanoporous Isopolyoxomolybdate as Highly Efficient

Recyclable Catalyst in Refluxing Water

Yahya Mirzaie, Jalil Lari, Hooshang Vahedi, Mohammad

Hakimi, Ahmad Nakhaei* and Abdolreza Rezaeifard

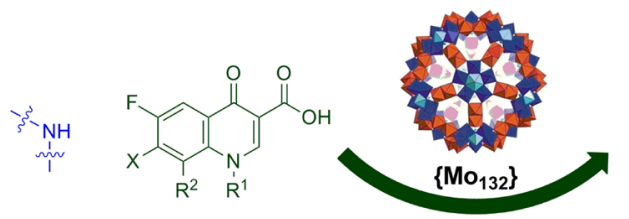

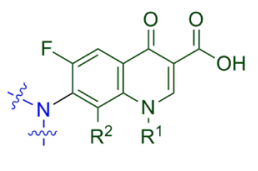

3

41-49 Synthesis and Biological Evaluation of New 3,4-diarylmaleimides as Enhancers (modulators) of Doxorubicin Cytotoxic Activity on Cultured Tumor Cells from a Real Case of Breast Cancer Jessica R. Gutierrez-Cano, Pradip D. Nahide, Velayudham Ramadoss, Yuvraj Satkar, Rafael OrtizAlvarado, Clara Alba-Betancourt, * Claudia L. MendozaMacias* and César R. Solorio-Alvarado*

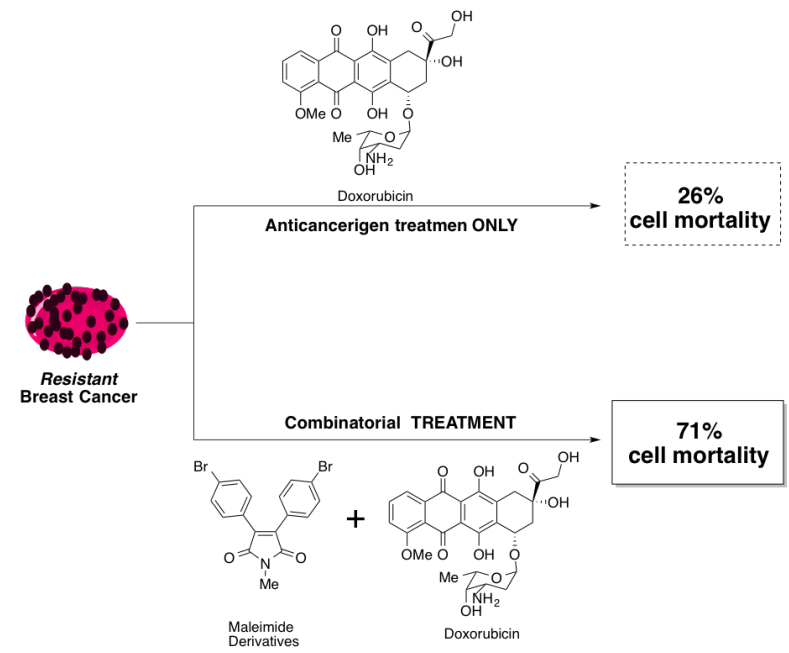

50-53 Microwave-assisted synthesis of ethyl 7-chloro-4-oxo1,4-dihydro-1,8-naphthyridine-3-carboxylate by the Grohe-Heitzer reaction

Socorro Leyva-Ramos, * Elisa Leyva, Jaime CardosoOrtiz and Hiram Hernández-López<smiles>CCOC(=O)c1c[nH]c2nc(Cl)ccc2c1=O</smiles>

54-59 Transformation of Ferulic Acid and Vanillin by Isolated Placentas of Capsicum chinense and Capsicum annuum Felipe Vázquez-Flota, * Miriam Monforte-González, Maria de Lourdes Miranda-Ham and Lizbeth A. CastroConcha

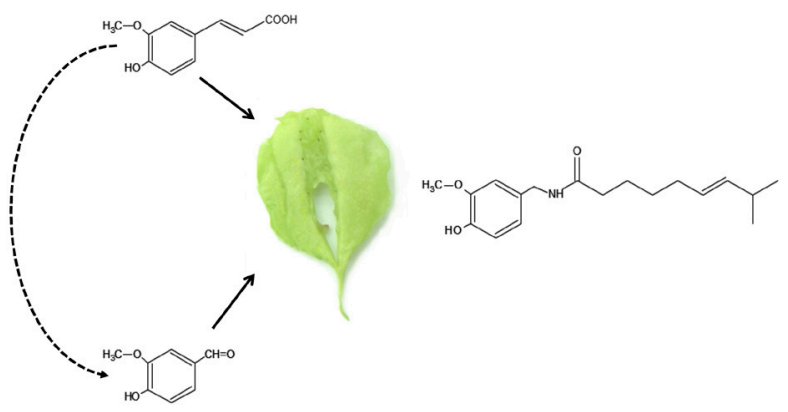




\section{Table of Contents}

60-66 GPU Algorithm for the Scaled Opposite-Spin (SOS) MP2 Energy Evaluation

Luis Ángel Martínez-Martínez and Carlos AmadorBedolla*

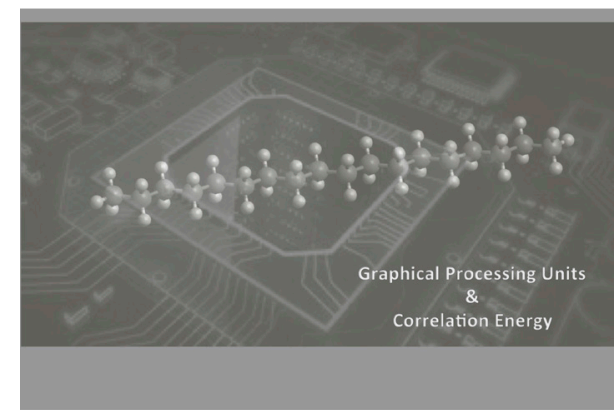

67-74 Tonantzitlolone $A$ and other cytotoxic constituents of Sapium macrocarpum (Euphorbiaceae)

Fernando Novillo, Verónica Rosero, María Isabel

Chávez, Simón Hernández-Ortega, Esteban M. Martínez and Guillermo Delgado*
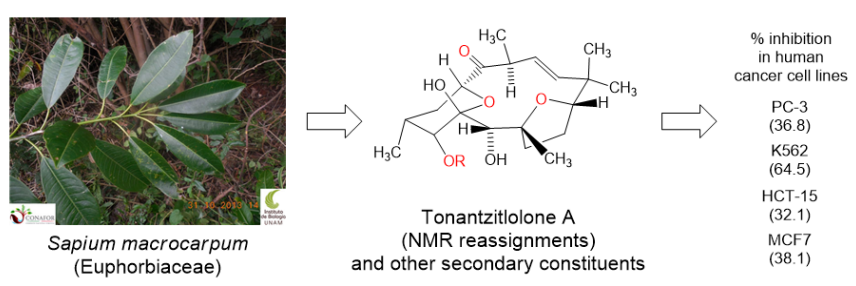



\title{
Cluster modeling and coordination structures of $\mathrm{Cu}^{+}$ions in Al-incorporated Cu-MEL catalysts - a density functional theory study
}

\author{
Mehdi Ghambarian, ${ }^{1}$ Zahra Azizi, ${ }^{2}$ and Mohammad Ghashghaee, ${ }^{3 *}$ \\ 1 Gas Conversion Department, Faculty of Petrochemicals, Iran Polymer and Petrochemical Institute, P.O. Box 14975-112, \\ Tehran, Iran. \\ 2 Department of Chemistry, Karaj Branch, Islamic Azad University, P.O. Box 31485-313, Karaj, Iran \\ 3 Faculty of Petrochemicals, Iran Polymer and Petrochemical Institute, P.O. Box 14975-112, Tehran, Iran \\ * Corresponding author. Tel.: +98 21 48662481; fax:+98 21 44787032. E-mail address: m.ghashghaee@ippi.ac.ir \\ Abbreviated running title: DFT modeling of Cu-ZSM-11 catalysts
}

Received July 8th, 2016; Accepted December 2nd, 2016.

\begin{abstract}
A density-functional-based cluster modeling was implemented on the Al-incorporated Cu-MEL zeolite catalyst (Cu-ZSM-11) to probe the electronic, energetic and structural features of the active sites of the catalyst at the B3LYP/6-311+G* and M06/Def2-TZVP levels. The HOMO-LUMO energy gap fell into the range of 3.31-5.15 $\mathrm{eV}$ at TD-BH\&HLYP/6-311+G* with the lowest magnitude for the I$\mathrm{Cu}$ and $\mathrm{M} 1-\mathrm{Cu}$ clusters. Population-averaged values for the exchange enthalpy and binding energy were also calculated, being approximately 125 and $171 \mathrm{kcal} / \mathrm{mol}$, respectively.
\end{abstract}

Keywords: Copper; MEL zeolite; DFT modeling; ZSM-11 catalysts; QTAIM.

\section{Introduction}

Transition-metal ions (TMIs) incorporated into zeolitic frameworks are known as active heterogeneous catalysts for numerous applications [1-3]. There has been fairly extensive research into copper ions impregnated over different supports [1, 4-17], which serve as efficient catalysts for a wide range of reactions, such as, methanol synthesis, oxidation of hydrocarbons, carbonylation of methanol, pollutant abatement, and hydrogenation reactions $[4-6,18]$. Among different metal exchanged zeolites, e.g., $\mathrm{Cu}-\mathrm{ZSM}-5$ proved to be the most active catalyst for direct decomposition of NO [8].

There exist several reports on the experimental identification as well as theoretical modeling of copper ions in porous materials [2, 4, 6-7, 17-38]. Meanwhile, the monovalent copper ion has received substantial interest. The adsorption of various probe molecules such as $\mathrm{NO}_{x}, \mathrm{CO}_{x}, \mathrm{~N}_{2}, \mathrm{O}_{2}$, and $\mathrm{H}_{2} \mathrm{O}$ on the $\mathrm{Cu}^{+}$ions exchanged into an MFI zeolite has been the subject of several studies [1, 7-9, 13-14, 20, 22, 37, 39-51]. The quantum chemical calculations have shown in accordance with IR measurements that the NO molecule is more freely activated on $\mathrm{Cu}^{+}$centers than on $\mathrm{Cu}^{2+}$ as evinced by the remarkably higher HOMO level of the former [20]. Unusual $\sigma$-type adsorption complexes with both hydrogen molecule and
Resumen: El modelado de closters empleando métodos derivados de la teoría de funcionales de la densidad fue aplicado al catalizador $\mathrm{Cu}$ MEL ceolita que incorpora aluminio (Cu-ZSM-11) para probar las características electrónicas, energéticas y estructurales del sitio activo del catalizador con los niveles de teoría B3LYP/6-311+G* y M06/ Def2-TZVP. La separación energética entre los orbitales HOMO y LUMO se encontró en el rango de 3.31 a 5.15 eV a nivel BH\&HLYP/6$311+\mathrm{G}$, teniendo el menor valor para los closters I-Cu y M1-Cu. También se determinaron los valores promedio de la población para la entalpía de intercambio y la energía de unión, con valores de 125 y 171 $\mathrm{kcal} / \mathrm{mol}$ respectivamente.

Palabras clave: cobre; MEL ceolita; modelado empleando DFT; catalizador ZSM-11; QTAIM.

light alkanes have been indicated for the $\mathrm{Cu}^{+}$ion, compared to other cations (e.g., $\mathrm{Li}^{+}$or $\mathrm{Mg}^{2+}$ ) [17]. The $\mathrm{Cu}^{+}$-exchanged zeolites are very promising adsorbents for the separation of olefins and desulfurization of fossil fuels [18].

Zeolite ZSM-11 is the most symmetrical pentasil observed so far [52]. The framework of ZSM-11 (MEL type) involves pentasil layers joined enantiomerically through $\sigma$-reflection, forming a two-dimensional network of straight channels with perpendicular intersections [52-54]. Experimental studies have demonstrated that both Cu-ZSM-11 (with MEL structure type with two-dimensional 10T-ring pores) and Cu-ZSM-12 (MTW structure of one-dimensional 12T-ring pores) are about twice as active as the most investigated zeolite Cu-ZSM-5 (MFI structure with straight and zig-zag/sinusoidal channels) in direct decomposition of $\mathrm{NO}[11,27]$. It was suggested that there must be a preferential formation of active sites and/or better accessibility in the straight channels compared to the sinusoidal ones, which explains the higher activity of ZSM-11 material [11]. Analogously, the Cu-ZSM-11 catalyst has been applied to direct $\mathrm{N}_{2} \mathrm{O}$ decomposition where it was obviously more active than $\mathrm{Cu}-\mathrm{ZSM}-5$ with the same $\mathrm{Si} / \mathrm{Al}$ ratio [55]. Synthesized mesoporous H-ZSM-11 catalysts have also shown extraordinary high activities in conversion of $n$-hexadecane [56]. 
It is believed that the coordination of the cation by the zeolite framework is vital for the catalytic properties of copper ions as the counterpart gas-phase ions do not confer such an activity [18]. DFT calculations have shown, e.g., that the interactions of $\mathrm{NO}$ with the gas-phase isolated $\mathrm{Cu}^{+}$ions are essentially different from those inside a zeolite structure. The former system showed interactions of the a' singly occupied orbital (SOMO) of NO with the unoccupied $4 \mathrm{~s}$ and the occupied $3 \mathrm{~d}$ orbitals of $\mathrm{Cu}^{+}$which depopulated the antibonding SOMO thus reinforcing the NO bond. In contrast, the $\mathrm{Cu}-\mathrm{zeo}-$ lite system showed increased Pauli repulsions due to electrostatic attractions which led to higher level (occupied) 3d orbitals interacting with the a" LUMO of NO molecule; these interactions populated the antibonding LUMO of NO and, hence, weakened the NO bond [7].

Despite the relative importance of the MEL-type materials, really scant attention has been directed in theoretical studies toward these catalysts [57-59]. The purpose of this paper is then to investigate the coordination, local structure and properties of $\mathrm{Cu}^{+}$ions at different positions within a ZSM-11 lattice. Knowledge of the properties of these cationic sites would be essential for a better understanding of their catalytic behaviors which facilitates their improvement and replacement with new zeolite-based catalysts.

\section{Results and discussion}

The overview of possible exchange sites in the porous network of an MEL-type zeolite is shown in Fig. 1, which illustrates an intersection site I, ring sites of M1, M2, M3, and M4 located in the main channels with an increasing number of $\mathrm{T}$ atoms from left to right, and cage-like positions $\mathrm{C} 1$ and $\mathrm{C} 2$ that resemble a curved 6T-ring site inside the walls of ZSM-11 composed of several fused 5T-rings.

As also mentioned above, the quantum-chemical studies of the deposition and binding of small metal particles on oxide surfaces are very important for obtaining an accurate description of the catalyst interface [4]. A major challenge concerning the structural characterization of metal-ion-exchanged zeolites, in general, is to find out where the cation substitution takes place and how metal ions are coordinated to the substituted sites [28]. As can be seen in Table 1 and Fig. 1, total of 7 sites were considered for $\mathrm{Cu}^{+}$exchange in ZSM-11, together with a representative A site from an MFI structure for comparison. The exchange sites of $\mathrm{C} 1$ and $\mathrm{C} 2$ have the same local environment in the solid matrix, but with $\mathrm{Al}$ incorporation at the $\mathrm{T} 6$ and $\mathrm{T} 1$ positions, respectively. The $\mathrm{C}$ sites in ZSM-11 are the most similar to the A site in ZSM-5, except that the $\mathrm{C}$ sites are not as readily accessible to guest molecules as the A site is. This subtle difference and similar differences in the accessibility and local configurations can evidently cause discrepancies in the bulk catalytic behavior of the two pentasil solids, even if the shape and population of exchange sites were identical in both cases. The other sites of the ZSM-11 catalyst are accessible to the coming molecules almost identically, provided that the pore diffusion effects in the similar cavities are the same.

At the first sight, one may think that few $\mathrm{Al}$ atoms have been considered here with respect to the framework Si atoms. Therefore, in reality, there must be some other $\mathrm{Al}$ atoms as well that influence the local environment of the $\mathrm{Cu}$ ions and

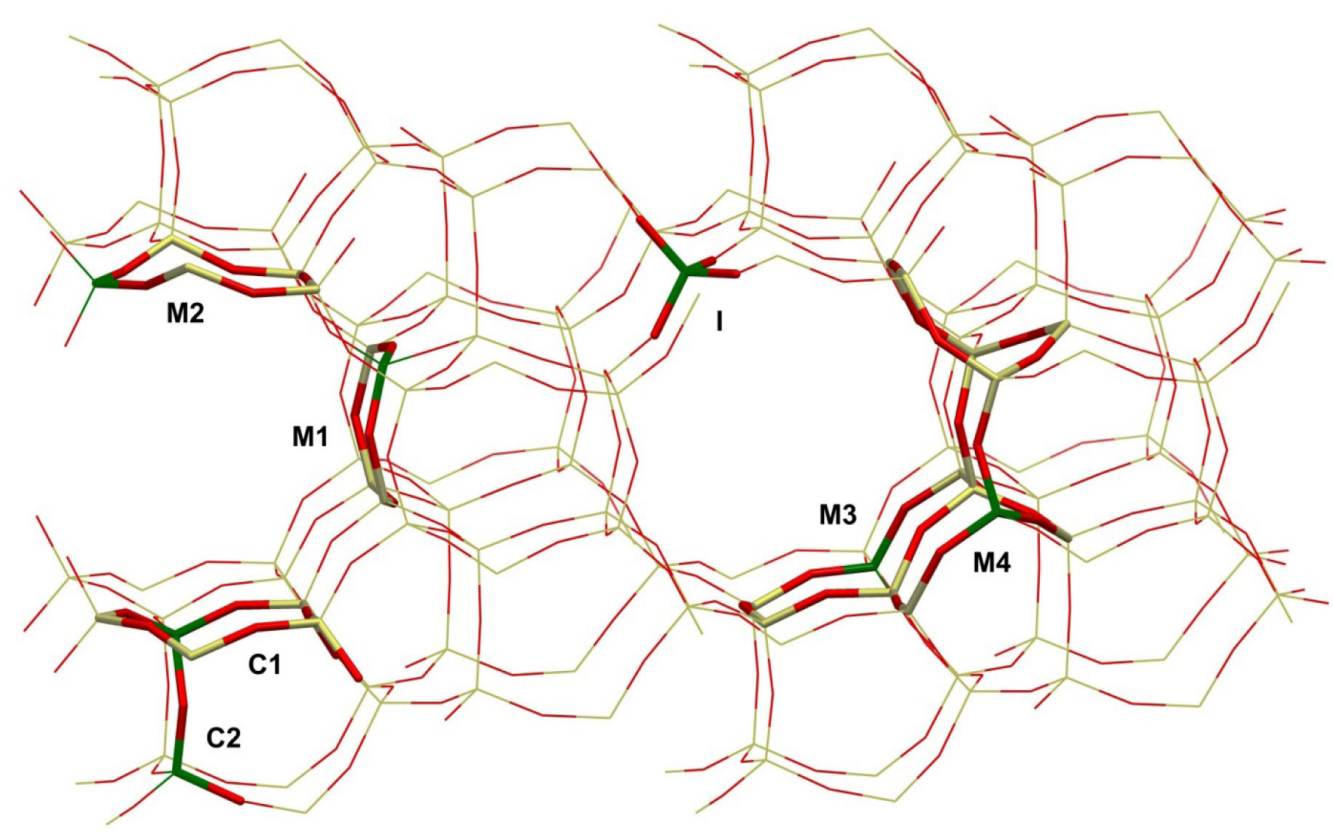

Fig. 1. Different positions for the placement of the $\mathrm{Cu}^{+}$ions in the ZSM-11 zeolite framework viewed at the (010) layer. The 10T-rings represent the main channels of the zeolite lattice. 
the considered intra-framework Al ones. However, we considered only one $\mathrm{Al}$ ion at each site. This is an assumption that is made not only for the simplicity of the calculations, but rather from a realistic point of view. In theory, the number of $\mathrm{Al}$ atoms in a zeolitic material is only limited by the Loewenstein rule (no adjacent $\mathrm{Al}$ tetrahedra) which requires $\mathrm{Si} / \mathrm{Al}$ ratios larger than 1. However, the MEL and MFI structures are normally listed as high-silica materials with a lower practical limit of 10 or 11 for the $\mathrm{Si} / \mathrm{Al}$ ratio [60-64]. Moreover, most of catalytic applications require moderate $\mathrm{Si} / \mathrm{Al}$ ratios to ascertain a balance between the number of acidic sites and the acid strength and hence for an optimum performance [60,62, 65-66]. The local $\mathrm{Si} / \mathrm{Al}$ ratios obtained from the atomic population in the isolated clusters lie in the range of 3-8, which are quite smaller than the observed lower limit above for an entire unit cell. Also worth noting is that the simulated acidic sites have a number of shared silicon atoms, making the average $\mathrm{Si} / \mathrm{Al}$ ratio further smaller. The possibilities for $\mathrm{Al}$ substitution and the subsequent models simulated here are then realistic and comprehensive enough, assuming a uniform substitution of the $\mathrm{Al}$ atoms. Zeolite samples with higher $\mathrm{Si} / \mathrm{Al}$ ratios can be modeled systematically by reducing the $\mathrm{Al}$ substitution sites according to their thermodynamic favorability. The same discussion holds for the $\mathrm{Cu}$ atoms assuming a one-by-one stoichiometric substitution of the exchangeable protons with the $\mathrm{Cu}^{+}$ions. In addition, our preliminary studies [67-68] indicated the suitability of the cutout clusters in modeling of the $\mathrm{Cu}-\mathrm{ZSM}-11$ catalyst in terms of thermodynamics, geometrical features, and HOMO-LUMO gaps and in addressing the border and confinement effects [69-74] normally contributing in microporous materials.

The optimized geometries of the $\mathrm{Cu}^{+}$active sites are shown in Fig. 2 for which Table 1 presents the highest occupied molecular orbital (HOMO) and the lowest unoccupied molecular orbital (LUMO) energy levels and their corresponding HOMO-LUMO gaps. The coordination states of copper in the cluster models shown in Fig. 2 have been determined from the electronic data reported in Table 3 (vide infra). Overall, the coordination of the copper ion is twofold in $\mathrm{I}-\mathrm{Cu}, \mathrm{M} 1-\mathrm{Cu}$, and $\mathrm{M} 4-\mathrm{Cu}$, threefold in $\mathrm{C} 1-\mathrm{Cu}$, and fourfold in $\mathrm{M} 2-\mathrm{Cu}, \mathrm{M} 3-\mathrm{Cu}, \mathrm{C} 2-\mathrm{Cu}$, and $\mathrm{A}-\mathrm{Cu}$. As it is seen, the incorporation of $\mathrm{Al}$ atom at the $\mathrm{T} 1$ position in the cage-like $\mathrm{C} 2$ site provides a higher coordination number for the $\mathrm{Cu}^{+}$ ion than that encompassing the $\mathrm{Al}$ atom at the $\mathrm{T} 6$ position (C1). Moreover, the corresponding site from ZSM-11 (C2) that resembles the alpha-site of ZSM-5 (A) has the same coordination number of four.

Table 1 may be used to draw some information about the available sites of the $\mathrm{Cu}-\mathrm{ZSM}-11$ in terms of reactivity. It has to be mentioned, however, that the exchange reactions and the catalysis events over the formed active sites are all of a transient nature where the reactants interact and their properties change continually upon approaching the active site. These aspects are normally studied using molecular dynamics simulations at the first-principles level [75-79]. For the comparisons made herein, it will be assumed that the distribution of the $\mathrm{Cu}^{+}$ions at the exchange locations and the following

Table 1. Calculated HOMO and LUMO energy levels and HOMO-LUMO energy gaps (eV) at B3LYP/6-311+G*, M06/Def2-TZVP, TD-B3LY$\mathrm{P} / 6-311+\mathrm{G}^{*}$, and TD-BH\&HLYP/6-311+G* for the $\mathrm{Cu}^{+}$active sites where the LUMO eigenvalue for the two latter was calculated by subtracting the HOMO eigenvalue from the HOMO-LUMO gap.

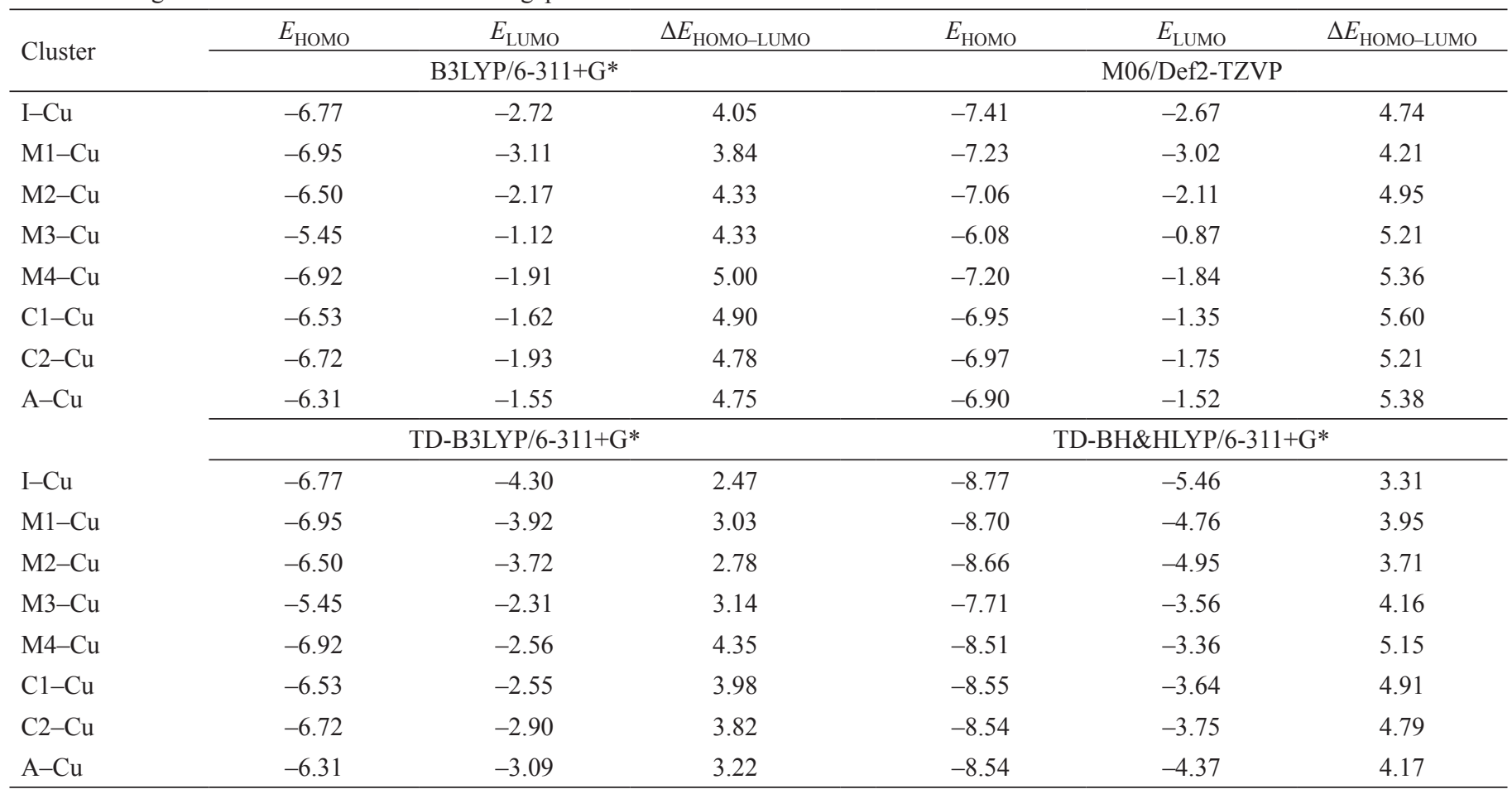



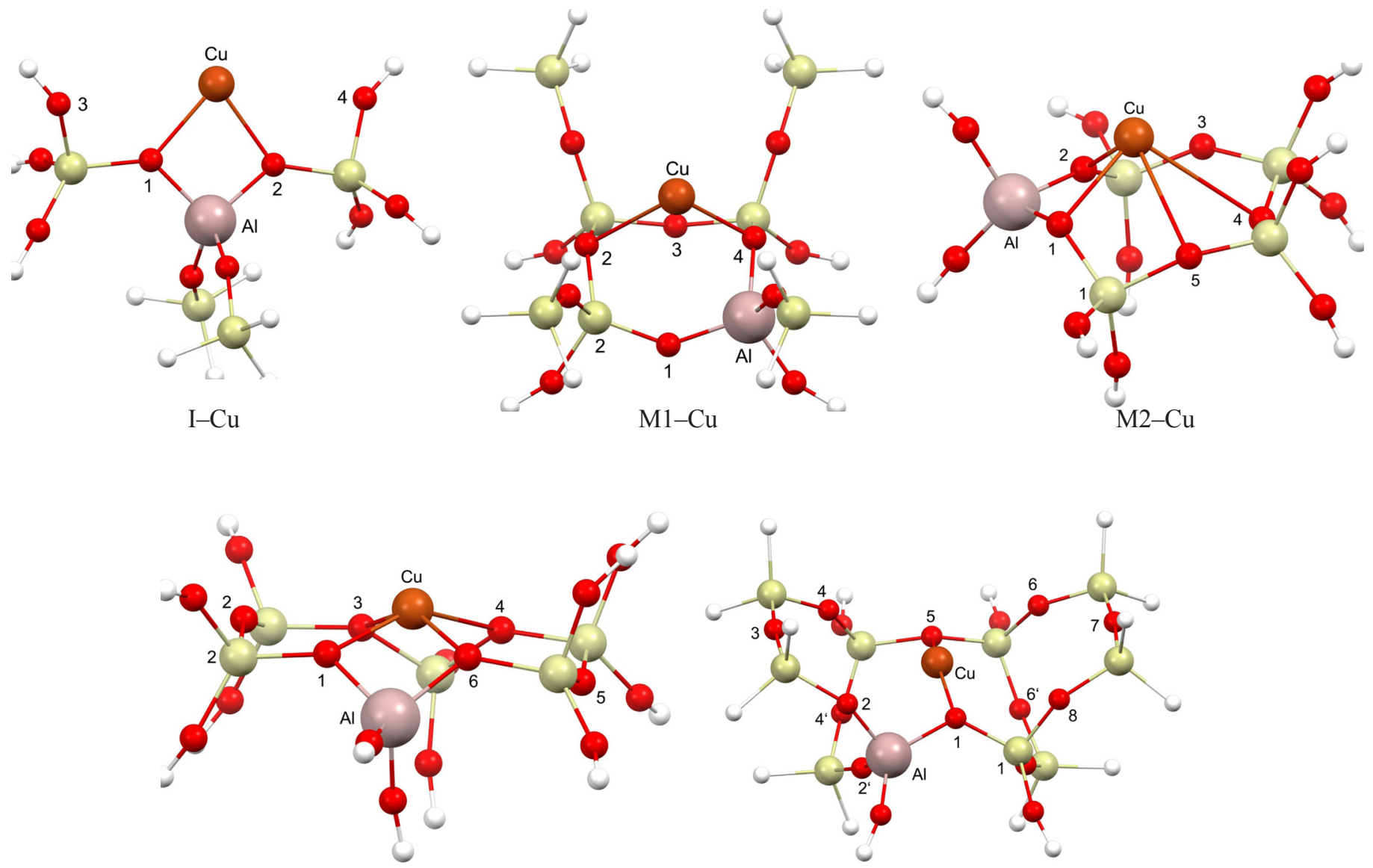

M3-Cu

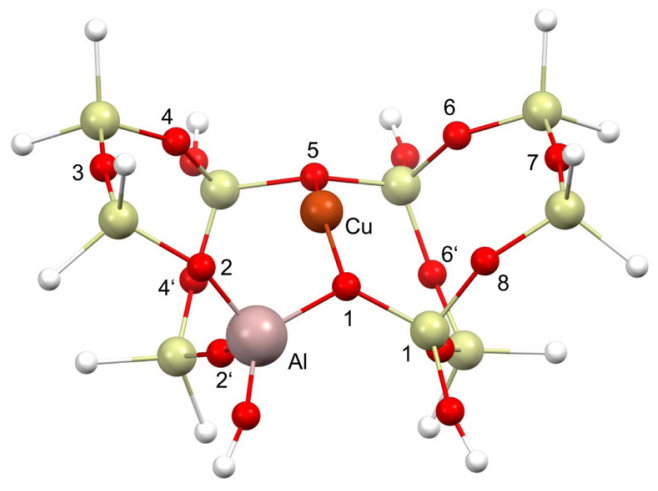

M4- $\mathrm{Cu}$

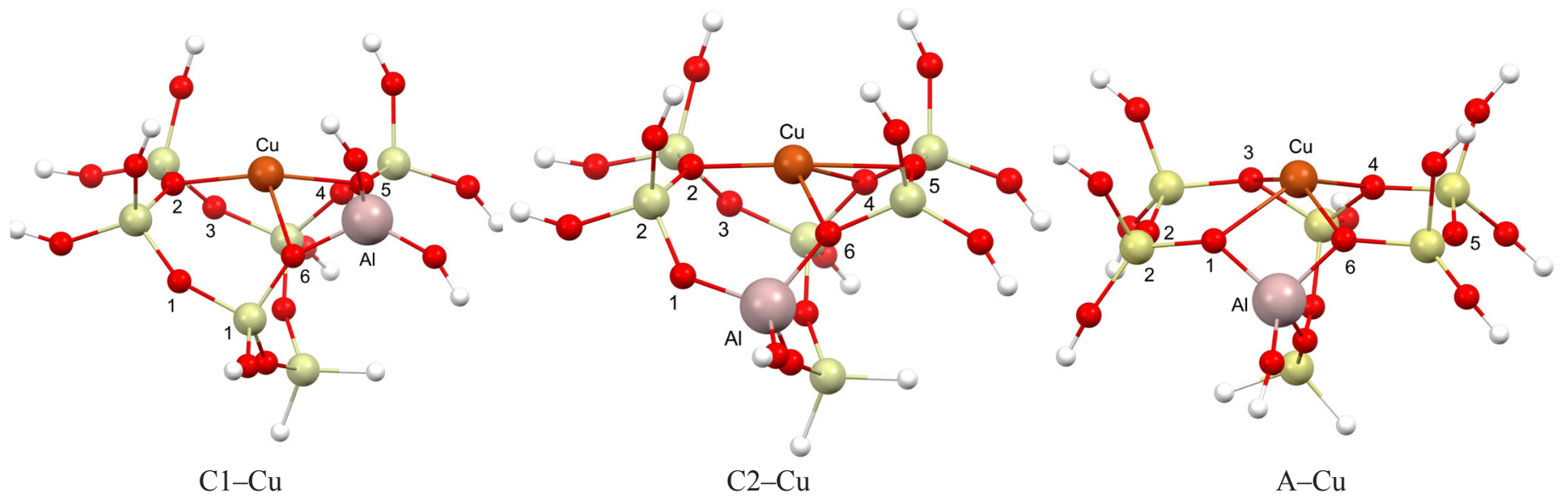

Fig. 2. Optimized geometries of the main Cu-MEL models. The darker (in red) atoms refer to lattice oxygen, the plain bigger balls of the framework (in yellow) represent silicon atoms, the copper ions are shown in brown, the aluminum substitutions are marked in violet, and the terminal white balls indicate saturating hydrogen atoms (For the color version of this figure, please refer to the electronic version of this article). The copper and aluminum atoms have also been labeled on each site for clarity.

reactivity-related consequences are determined by their thermodynamic favorability rather than by any kinetic events as also adopted earlier [57, 80-82]. Supplementary comments will be made on the accessibility of the active sites for the reactant molecules, however. Although hybrid functionals (such as
B3LYP and M06) generally predict accurate HOMO-LUMO gaps in transition-metal exchanged zeolites [83-84], Zhang and Musgrave [85] reported after careful analysis against experimental lowest excitation energies of a number of molecules that only time-dependent (TD) DFT methods accurately predict 
the HOMO-LUMO gaps. Therefore, we included also the TDB3LYP and TD-BH\&HLYP [86-87] functionals in evaluating the frontier orbital energy data. Moreover, the discussion made here on the reactivity-driven electron transfer tendency of the $\mathrm{CuZ}$ sites with respect to an adsorbate should not be confused with the standard definitions of electrodonating and electroaccepting powers [88-91].

Wherever the Cu-MEL catalyst can play the role of an electron donor with respect to an adsorbate species, a higher HOMO energy level of the CuZ means a higher propensity for electron donation to the LUMO of the guest molecule. Here, the M3-Cu structure (with the HOMO levels of -6.08 $\mathrm{eV}$ at M06/Def2-TZVP and -7.71 at TD-BH\&HLYP/6$\left.311+\mathrm{G}^{*}\right)$ presents the highest reactivity towards a stronger electron-acceptor species/ligand. In contrast, the $\mathrm{I}-\mathrm{Cu}$ and $\mathrm{M} 1-\mathrm{Cu}$ sites were presented by different methods to be the least reactive sites in terms of the HOMO level; the coordination number of copper in both of them is two while in $\mathrm{M} 3-\mathrm{Cu}$ is four (Fig. 2), however. The findings are then generally consistent with the trends reported in the literature [48-49] stating that the electron-donation power of the active site correlates well with the degree of coordination. The HOMO energy level of A-Cu differed from $-8.54 \mathrm{eV}$ to $-6.31 \mathrm{eV}$ which was slightly lower than the previously reported magnitude of $-5.17 \mathrm{eV}$ by Broclawik et al. [20] for $\mathrm{Cu}^{+}$exchanged into an alpha-site of ZSM-5. Apart from a difference in the level of the computations or the computational methods, the differences may be attributed to the fact that two $\mathrm{Al}$ atoms were present at the $\mathrm{T} 1$ and $\mathrm{T} 4$ positions in that paper.

When CuZ clusters can accept electrons from a stronger donor, such as ammonia [19], a lower LUMO energy level translates into an easier reaction with the guest molecule. As apparent from Table 1, a reverse trend compared to what explained for the HOMO level is true for the LUMO level, i.e., the $\mathrm{I}-\mathrm{Cu}$ and $\mathrm{M} 1-\mathrm{Cu}$ sites are predicted to be the best electron acceptors from the HOMO of a guest molecule within the framework of the frontier molecular orbital (FMO) theory [92]. On the contrary, the LUMO level of the M3-Cu site stands higher than any other site according to most of the methods, indicating its weakest electron-accepting property. Comparing the HOMO and LUMO levels of the A-Cu site with those of its equivalent in MEL structure $(\mathrm{C} 2-\mathrm{Cu})$, one may conclude that the resemblance of the geometries from two similar pentasil materials in terms of the ring size will not assure similarities between all of their properties. The same issue holds true for the two cage-like structures with Al replacement at $\mathrm{T} 1$ or $\mathrm{T} 6$ positions.

As it is well-known [93-97], a relatively small gap between the HOMO and LUMO energy levels reflects a high polarizability, less significant hardness, and higher reactivity. Whereas most of the methods predicted $\mathrm{M} 4-\mathrm{Cu}$ as the most stable site, the I-Cu and M1-Cu clusters were estimated as the most reactive. Despite the general trends observed, no significant correlation could be established between the HOMO-LUMO gaps by methods of different category. We note, however, that some linear correlations exist between the frontier orbital energy levels predicted by the two methods within each category (see Supporting Information, Fig. S1).

The bond critical point properties determined for the $\mathrm{CuZ}$ clusters are shown in Table 2 which indicates low electron densities with a local depletion of the internuclear densities for all of the investigated sites. This agrees with the general expectation that metal-oxygen interactions are normally characterized through positive values of $\nabla^{2} \rho$ at the $\mathrm{BCP}$ [13]. According to the quantum theory of atoms in molecules (QTAIM) [98-99], the existence of a $(3,-1)$ critical point in the electron density distribution along the path between a pair of atoms indicates that the electron density is localized in the binding region between the nuclei, thus being an indicator of the presence of a chemical bond. Moreover, the electron density at BCP may be regarded as a direct indicator of the bond order. Based on the QTAIM calculations, the nature of the chemical bonds may be described in terms of electron density $\rho(r)$ and the corresponding Laplacian $\nabla^{2} \rho(r)$ at the bond critical point (BCP). According to this theory, $\nabla^{2} \rho(r)$ provides information about the electronic charge and the degree of local depletion or concentration of the interatomic densities $[13,99]$. The positive values of $\nabla^{2} \rho(r)$ point to closed-shell electrostatic interactions, particularly because the $\left|\lambda_{1}\right| / \lambda_{3}$ ratio is much smaller than 1 . However, the intrinsic nature of the electron density distributions in the interatomic region of the interactions entail that the positive eigenvalue of the Hessian matrix at the BCP decreases with increasing the $\mathrm{Cu}-\mathrm{O}$ bond distances, thus rendering systematic reductions in $\nabla^{2} \rho(r)$ (vide infra). The QTAIM calculations led to no BCP data for the copper-silicon or copper-aluminum interactions.

Table 3 reports the $\mathrm{NBO}$ charges of $\mathrm{Cu}, \mathrm{Al}$, and $\mathrm{O}$ atoms in the $\mathrm{CuZ}$ clusters where a partial charge transfer from the zeolite substrate to the orbitals of the metal is clear. Earlier studies have also shown that the positive charge of the $\mathrm{Cu}$ ion shrinks upon adsorption on a zeolite surface owing to remarkable charge transfers from the siloxy groups of the surface to the metal ion [33, 100-101]. An opening (hybridization) of the $d$-shell on the $\mathrm{Cu}^{+}$is a requisite for this electron transfer [7]. The most positive charge on $\mathrm{Cu}^{+}$is observed for the $\mathrm{I}-\mathrm{Cu}$ cluster $(0.898 \mathrm{e})$ while the highest deviation from the formal cationic charge of +1 is found on $\mathrm{C} 1-\mathrm{Cu}$ and $\mathrm{C} 2-\mathrm{Cu}$ with interestingly similar charges $(0.672 \mathrm{e})$. As a result, the highest charge transfer from the surface to the cation occurs at the cagelike positions as comprehended from a shrinkage of the positive charge of $\mathrm{Cu}$ cation with respect to its formal charge. This charge transfer varied from $0.10 \mathrm{e}$ to $0.33 \mathrm{e}$; these values were in agreement with the lower limit $(0.33 \mathrm{e})$ reported for the $\mathrm{Cu}_{n} \mathrm{O}$ clusters [102] and very similar to the values obtained for other complexes of $\mathrm{Cu}(\mathrm{I})$ [103-104]. At the same time, no one-to-one relationship could be established between the amount of charge transfer and coordination number of $\mathrm{Cu}$ ion.

Table 4 contains the bond lengths for all of the $\mathrm{Cu}-$ ZSM-11 cluster models. The three smallest $\mathrm{Cu}-\mathrm{O}$ bond lengths $(1.925,1.939$, and $1.946 \AA)$ belong to the $\mathrm{M} 4-\mathrm{Cu}, \mathrm{C} 1-$ $\mathrm{Cu}$, and $\mathrm{C} 2-\mathrm{Cu}$ sites, respectively. The minimum $r(\mathrm{Cu}-\mathrm{Al})$ 
Table 2. Topological properties of the $\mathrm{Cu}-\mathrm{O}$ bonds at the bond critical point for the investigated $\mathrm{Cu} / \mathrm{ZSM}-11$ catalysts at the B3LY$\mathrm{P} / 6-311+\mathrm{G}^{*}$ level.

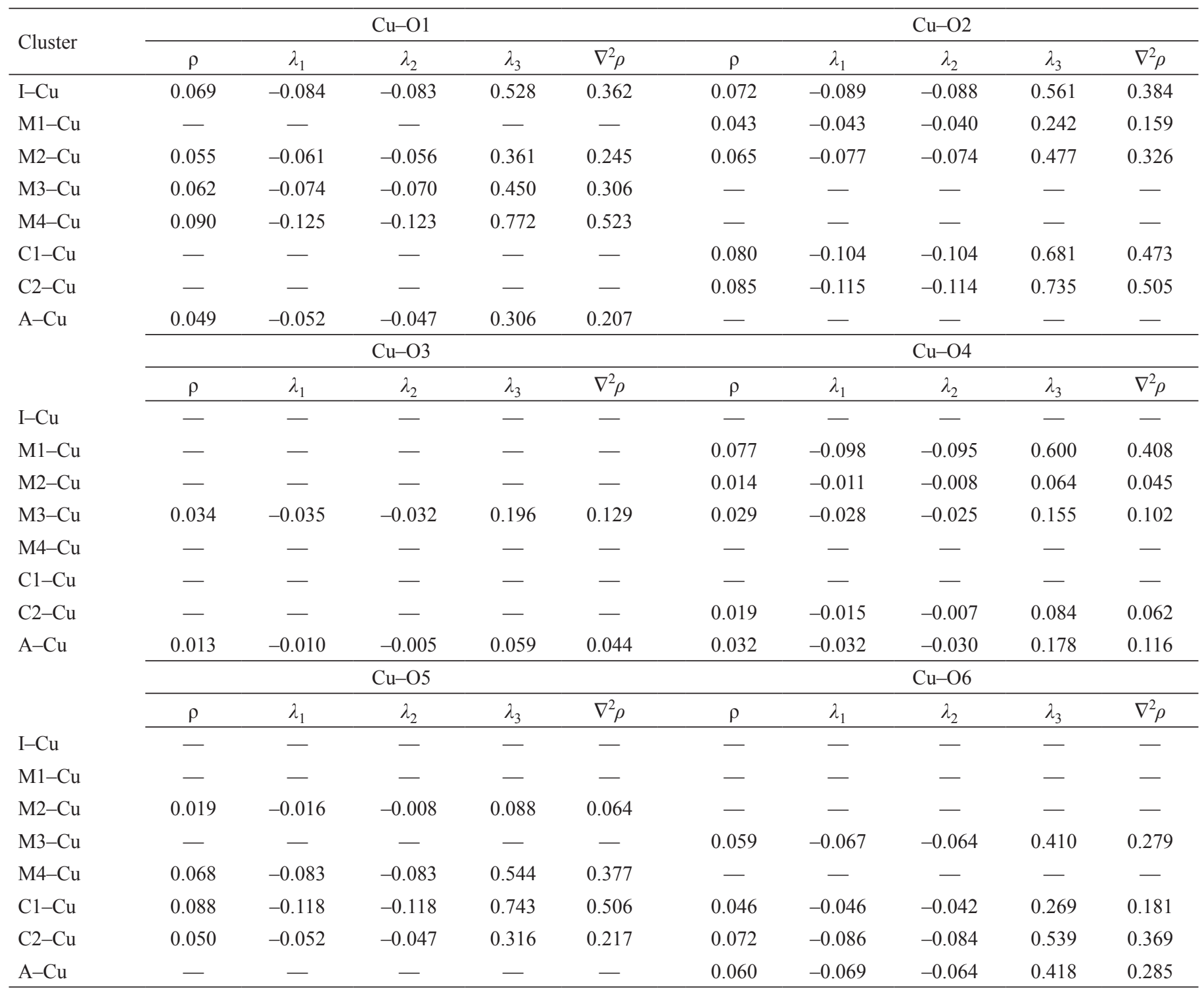

was observed for the M2-Cu site. However, the $r(\mathrm{Cu}-\mathrm{Al})$ in $\mathrm{C} 2-\mathrm{Cu}$ was the maximum $r(\mathrm{Cu}-\mathrm{Al})$ observed and the other $r(\mathrm{Cu}-\mathrm{O})$ values in $\mathrm{C} 2-\mathrm{Cu}$ were large. The results of Table 4 can also show that no perfect symmetrical configurations (with identical $\mathrm{Cu}-\mathrm{O}$ bond lengths) as observed in the case of $\mathrm{Zn}$ cation interactions with an all-silica MEL structure [57] are found here for the $\mathrm{CuZ}$ clusters because of the presence of an $\mathrm{Al}$ atom in the ring sites. Table 4 also signifies a correspondence between the values of $r(\mathrm{Cu}-\mathrm{O})$ and $r(\mathrm{Cu}-$ $\mathrm{Si}$ ), which is anticipated.

As expressed by Šponer et al. [38], the coordination of metal cations such as $\mathrm{Cu}^{+}$in zeolites involves an electronic perturbation of the charge distribution over the binding sites where the extent of charge transfer should correlate with the formal charge of the ion and the bond length parameters. Such a correlation was reported previously for the interactions of $\mathrm{Zn}^{2+}$ adsorbed on a silicalite-2 structure [57]. Comparing the data reported in Tables 3 and 4 along with an account of the coordination numbers in Fig. 2, however, no well-developed correlations could be obtained here between the bond length parameters and the NBO charge data including $q(\mathrm{Cu}-\mathrm{O})$. Instead, some excellent correlations are displayed between some of the bond critical point properties and the corresponding bond lengths (Fig. 3). All of the $\mathrm{Cu}-\mathrm{O}$ bonds recognized by the QTAIM approach were used to assert these correlations. The exchange and binding energies and the reported HOMO, LUMO, and HOMO-LUMO gap were independent of the bond length or the bond critical point data. The third (positive) eigenvalue of the Hessian matrix of the electron distribution at the BCP describes the local depletion of the electron density in the binding 
Cluster modeling and coordination structures of $\mathrm{Cu}^{+}$ions in Al-incorporated $\mathrm{Cu}-\mathrm{MEL}$ catalysts - a density functional theory study

Table 3. Partial charge of the $\mathrm{Cu}$ ion, $\mathrm{Al}$ atom and lattice $\mathrm{O}$ atoms in the investigated cluster models of $\mathrm{Cu} / \mathrm{ZSM}-11$ at the $\mathrm{B} 3 \mathrm{LYP} / 6-311+\mathrm{G} *$ level.

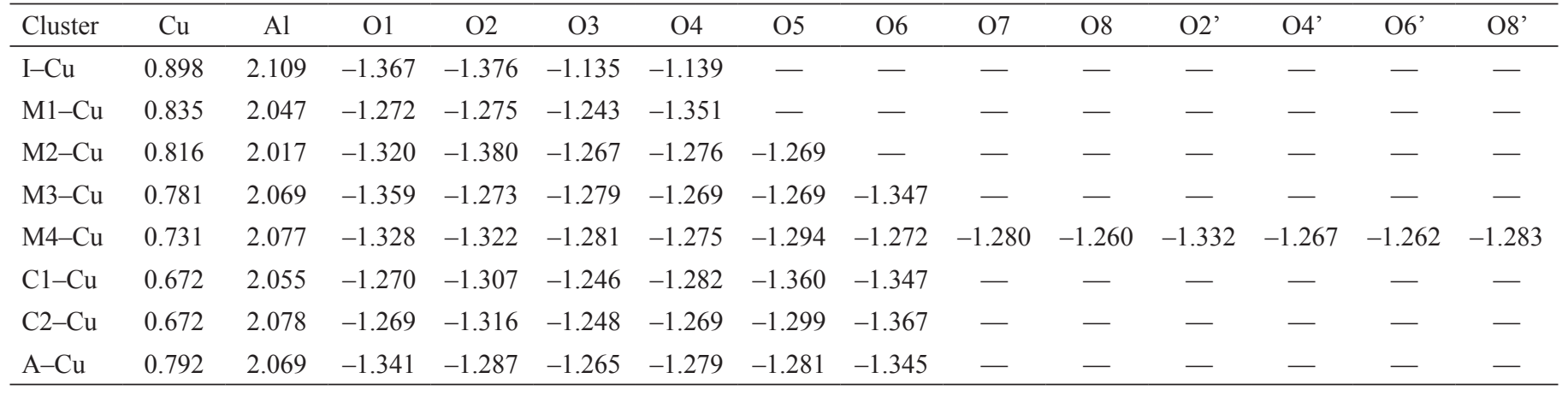

Table 4. Copper-framework atom bond lengths obtained for the optimized Cu/ZSM-11 cluster models $(\AA)$ at the B3LYP/6-31+G* level.

\begin{tabular}{|c|c|c|c|c|c|c|c|c|}
\hline Cluster & $\mathrm{I}-\mathrm{Cu}$ & $\mathrm{M} 1-\mathrm{Cu}$ & $\mathrm{M} 2-\mathrm{Cu}$ & $\mathrm{M} 3-\mathrm{Cu}$ & $\mathrm{M} 4-\mathrm{Cu}$ & $\mathrm{C} 1-\mathrm{Cu}$ & $\mathrm{C} 2-\mathrm{Cu}$ & $\mathrm{A}-\mathrm{Cu}$ \\
\hline $\mathrm{Cu}-\mathrm{O} 1$ & 2.038 & 2.956 & 2.161 & 2.091 & 1.925 & 2.975 & 3.167 & 2.207 \\
\hline $\mathrm{Cu}-\mathrm{O} 2$ & 2.022 & 2.289 & 2.072 & 3.007 & 3.150 & 1.970 & 1.946 & 3.341 \\
\hline $\mathrm{Cu}-\mathrm{O} 3$ & 3.450 & 3.163 & 3.007 & 2.365 & 3.880 & 3.264 & 3.214 & 2.888 \\
\hline $\mathrm{Cu}-\mathrm{O} 4$ & 3.191 & 2.002 & 2.877 & 2.457 & 2.973 & 2.889 & 2.744 & 2.398 \\
\hline $\mathrm{Cu}-\mathrm{O} 5$ & - & - & 2.704 & 3.202 & 2.036 & 1.939 & 2.200 & 3.168 \\
\hline $\mathrm{Cu}-\mathrm{O} 6$ & - & - & - & 2.117 & 3.152 & 2.256 & 2.039 & 2.113 \\
\hline $\mathrm{Cu}-\mathrm{O} 7$ & - & - & - & - & 4.102 & - & - & - \\
\hline $\mathrm{Cu}-\mathrm{O} 8$ & - & - & - & - & 3.321 & - & - & - \\
\hline $\mathrm{Cu}-\mathrm{O} 2$ & - & - & - & - & 2.932 & - & - & - \\
\hline $\mathrm{Cu}-\mathrm{O} 4$ & - & - & - & - & 3.289 & - & - & - \\
\hline $\mathrm{Cu}-\mathrm{O} 6$ & - & - & - & - & 3.427 & - & - & - \\
\hline $\mathrm{Cu}-\mathrm{O} 8$ & - & - & - & - & 3.074 & - & - & - \\
\hline $\mathrm{Cu}-\mathrm{Al}$ & 2.743 & 2.783 & 2.617 & 2.764 & 2.837 & 2.696 & 3.058 & 2.653 \\
\hline $\mathrm{Cu}-\mathrm{Si} 1$ & 3.396 & - & 3.049 & - & 2.959 & 3.201 & - & - \\
\hline $\mathrm{Cu}-\mathrm{Si} 2$ & 3.354 & 2.889 & - & 3.247 & - & 2.856 & 2.832 & 3.368 \\
\hline $\mathrm{Cu}-\mathrm{Si} 3$ & - & 3.090 & 3.276 & 3.338 & 4.143 & 3.005 & 3.005 & 3.632 \\
\hline $\mathrm{Cu}-\mathrm{Si} 4$ & - & 3.011 & 3.415 & 2.999 & 4.052 & 3.376 & 3.293 & 3.194 \\
\hline $\mathrm{Cu}-\mathrm{Si} 5$ & - & - & 3.138 & 3.342 & 2.933 & 2.937 & 2.926 & 3.246 \\
\hline $\mathrm{Cu}-\mathrm{Si} 6$ & - & - & - & 3.253 & 3.051 & - & 2.680 & 3.180 \\
\hline $\mathrm{Cu}-\mathrm{Si} 7$ & - & - & - & - & 4.258 & - & - & - \\
\hline $\mathrm{Cu}-\mathrm{Si} 8$ & - & - & - & - & 4.347 & - & - & - \\
\hline
\end{tabular}

region. As evident, this eigenvalue which is a measure of the curvatures parallel to the bond path has a descending power-law relationship with the corresponding $\mathrm{Cu}-\mathrm{O}$ bond length. This inverse interconnection reflects [105] an increase in the force constant of the bond that makes the shorter $\mathrm{Cu}-\mathrm{O}$ bonds more resistant to the changes due to compactions. Both of the electron density and its Laplacian show similar power-type correlations with the $\mathrm{Cu}-\mathrm{O}$ bond length in the metal-zeolite system at hand, indicating that the electronic features of the $\mathrm{Cu}-\mathrm{O}$ bonds in this system can be adequately determined from the bond distances (Fig. 3). The calculated bond lengths evidently correlate with $\left|\lambda_{1,2}\right|$ as well, which is not shown here for the sake of brevity. Similar trends have been reported for the $\mathrm{Si}-\mathrm{O}$ bonds in silica polymorph materials [105-106], hydrogen bonds in cyclic dimers [107], O-H interactions between interactions between $\mathrm{N}$-butylpyridinium nitrate and thiophenic compounds [108], and $\mathrm{Ni}-\mathrm{Ni}$ and $\mathrm{Ni}-\mathrm{S}$ bonds [109].

Table 5 lists some important bond angles for the investigated sites. As evident from this table, the $\mathrm{O}-\mathrm{Cu}-\mathrm{O}$ bond angles vary from the largest to the smallest in the following order: $\mathrm{C} 2-\mathrm{Cu}, \mathrm{C} 1-\mathrm{Cu}, \mathrm{M} 4-\mathrm{Cu}, \mathrm{M} 3-\mathrm{Cu}, \mathrm{M} 2-\mathrm{Cu}, \mathrm{M} 1-\mathrm{Cu}$, and $\mathrm{I}-\mathrm{Cu}$. As also evidenced from the $\mathrm{O}-\mathrm{O}-\mathrm{Cu}$ bond angles in $\mathrm{C} 2-\mathrm{Cu}$ through $\mathrm{M} 2-\mathrm{Cu}$, the $\mathrm{Cu}^{+}$ion prefers an arrangement as more flattened as possible in the available ring sites. 

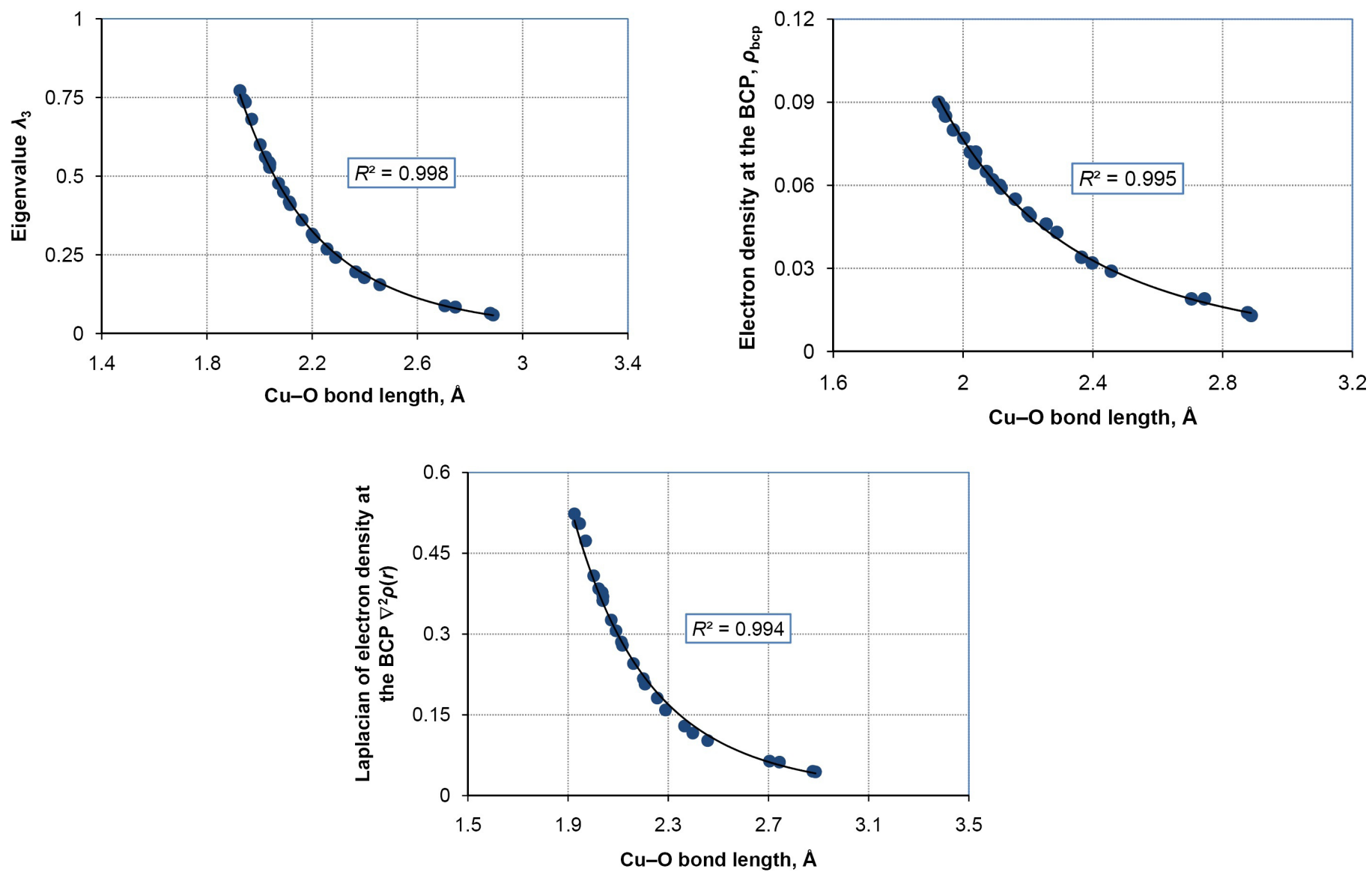

Fig. 3. Significant correlations observed between the electronic features and structural properties of the molecular models of the Cu-MEL zeolite catalyst. The fitting curves obeyed power-law functions with the exponents of $-6.3,-6.2$, and -4.6 for the correlations of $\lambda_{3}$, $\rho_{\text {bcp }}$, and $\nabla^{2} \rho_{\text {bcp }}$, respectively.

No exact connection could be established between the arrangement of the $\mathrm{Cu}$ ion and the degree of coordination or the reactivity of the $\mathrm{CuZ}$ cluster in terms of the HOMOLUMO gaps.

Table 6 reports the enthalpy and Gibbs free energy change for the exchange reaction, Eq. (2), and the energy for the metal ion binding as in Eq. (1). As evident, the enthalpy of $\mathrm{Cu}$ grafting for the investigated clusters ranged from $108.93 \mathrm{kcal} / \mathrm{mol}$ $(\mathrm{M} 3-\mathrm{Cu})$ to $141.14 \mathrm{kcal} / \mathrm{mol}(\mathrm{M} 1-\mathrm{Cu})$. This indicates that the ion exchange on all of the acidic sites of ZSM-11 would be endothermic. Overall, the sequence of the thermodynamic privilege for the ion exchange is $\mathrm{M} 3>\mathrm{C} 1>\mathrm{I}>\mathrm{A}>\mathrm{C} 2>\mathrm{M} 2>\mathrm{M} 4$ $>\mathrm{M} 1$ as found from the Gibbs free energies of the exchange reaction. The most thermodynamically favored cluster to be formed is therefore the M3-Cu site followed by $\mathrm{C} 1-\mathrm{Cu}$ and I$\mathrm{Cu}$ which cover coordination numbers of 2-4. This means that the thermodynamic favorability of the exchange reaction is not determined by the final coordination of the cation. Moreover, the data show that the ion exchange reaction is non-spontaneous at $298 \mathrm{~K}$ and $1 \mathrm{~atm}$. Comparing the alpha site with $\mathrm{C} 2$ as its counterpart from ZSM-11 in terms of geometry, one can interestingly notice their close favorability for a copper/proton
Table 5. Selected bond angles for the $\mathrm{Cu} / \mathrm{ZSM}-11$ clusters (in degrees) at the B3LYP/6-31+G* level.

\begin{tabular}{|c|c|c|c|c|}
\hline Cluster & \multicolumn{2}{|c|}{ Angle $\left(^{\circ}\right)$} & \multicolumn{2}{|c|}{ Angle $\left(^{\circ}\right)$} \\
\hline $\mathrm{I}-\mathrm{Cu}$ & $\mathrm{O} 1-\mathrm{Cu}-\mathrm{O} 2$ & 77.97 & - & - \\
\hline $\mathrm{M} 1-\mathrm{Cu}$ & $\mathrm{O} 2-\mathrm{Cu}-\mathrm{O} 4$ & 100.48 & - & - \\
\hline $\mathrm{M} 2-\mathrm{Cu}$ & $\mathrm{O} 2-\mathrm{Cu}-\mathrm{O} 5$ & 110.88 & $\mathrm{O} 2-\mathrm{O} 4-\mathrm{Cu}$ & 55.82 \\
\hline $\mathrm{M} 3-\mathrm{Cu}$ & $\mathrm{O} 1-\mathrm{Cu}-\mathrm{O} 4$ & 147.53 & $\mathrm{O} 1-\mathrm{O} 2-\mathrm{Cu}$ & 43.61 \\
\hline $\mathrm{M} 4-\mathrm{Cu}$ & $\mathrm{O} 1-\mathrm{Cu}-\mathrm{O} 5$ & 153.05 & $\mathrm{O} 1-\mathrm{O} 2-\mathrm{Cu}$ & 37.61 \\
\hline $\mathrm{C} 1-\mathrm{Cu}$ & $\mathrm{O} 2-\mathrm{Cu}-\mathrm{O} 5$ & 158.26 & $\mathrm{O} 1-\mathrm{O} 4-\mathrm{Cu}$ & 29.78 \\
\hline $\mathrm{C} 2-\mathrm{Cu}$ & $\mathrm{O} 2-\mathrm{Cu}-\mathrm{O} 5$ & 166.10 & $\mathrm{O} 1-\mathrm{O} 4-\mathrm{Cu}$ & 29.11 \\
\hline $\mathrm{A}-\mathrm{Cu}$ & $\mathrm{O} 3-\mathrm{Cu}-\mathrm{O} 6$ & 145.06 & $\mathrm{O} 3-\mathrm{O} 6-\mathrm{Cu}$ & 20.26 \\
\hline
\end{tabular}


exchange (Table 6). The results presented here also show that the cage-like locations with the $\mathrm{Al}$ atom at the $\mathrm{T} 1$ position are less prepared for a copper exchange than those with $\mathrm{Al}$ atom at the T6 position. As far as the most accessible sites for a coming molecule are concerned, however, both I and M3 positions are readily exchanged.

Table 6. The exchange and binding energies of the $\mathrm{Cu}^{+}$ions in the active sites of ZSM-11 at the B3LYP/6-311+G* level [Please see reactions (1) and (2) in the text, respectively, for the calculation of the binding and exchange energies].

\begin{tabular}{lcccc}
\hline Cluster & $\begin{array}{c}\text { Population } \\
(\%)\end{array}$ & $\begin{array}{c}\Delta E_{\mathrm{b}} \\
(\mathrm{kcal} / \mathrm{mol})\end{array}$ & $\begin{array}{c}\Delta H_{\mathrm{ex}} \\
(\mathrm{kcal} / \mathrm{mol})\end{array}$ & $\begin{array}{c}\Delta G_{\mathrm{ex}} \\
(\mathrm{kcal} / \mathrm{mol})\end{array}$ \\
\hline $\mathrm{I}-\mathrm{Cu}$ & 48.1 & 174.01 & 121.11 & 128.73 \\
$\mathrm{M} 1-\mathrm{Cu}$ & 11.1 & 146.99 & 141.14 & 149.01 \\
$\mathrm{M} 2-\mathrm{Cu}$ & 14.8 & 173.04 & 129.29 & 138.73 \\
$\mathrm{M} 3-\mathrm{Cu}$ & 7.4 & 195.45 & 108.93 & 114.47 \\
$\mathrm{M} 4-\mathrm{Cu}$ & 7.4 & 161.24 & 132.41 & 144.08 \\
$\mathrm{C} 1-\mathrm{Cu}$ & $5.6^{\mathrm{a}}$ & 174.99 & 120.47 & 127.11 \\
$\mathrm{C} 2-\mathrm{Cu}$ & $5.6^{\mathrm{a}}$ & 158.08 & 128.11 & 137.82 \\
Overall & 100 & 170.68 & 124.84 & 132.96 \\
$\mathrm{~A}-\mathrm{Cu}$ & - & 179.71 & 126.17 & 133.32 \\
\hline
\end{tabular}

a The population of the $\mathrm{C}$ positions was equally distributed between the $\mathrm{C} 1-\mathrm{Cu}$ and $\mathrm{C} 2-\mathrm{Cu}$ sites.

b The overall values were obtained assuming a uniform monolayer coverage on all sites considering the population of each site as its weight factor.

Also listed in Table 6 are the overall values of the energetic data which were obtained through averaging of the individual values of the available sites according to their population contributions in the zeolite matrix. The populations were found by counting the number of each site in a doubled unit cell. Table 6 also reports the $\mathrm{Cu}^{+}$binding energy for the studied $\mathrm{CuZ}$ clusters. As evident, the binding energy ranged from 146.99 to $195.45 \mathrm{kcal} / \mathrm{mol}$ where the highest and the lowest values were assigned to the $\mathrm{M} 3-\mathrm{Cu}$ and $\mathrm{M} 1-\mathrm{Cu}$ sites, respectively. This strongest binding is followed by the $\mathrm{A}-\mathrm{Cu}$, $\mathrm{C} 1-\mathrm{Cu}$ and $\mathrm{I}-\mathrm{Cu}$ sites, with the $\mathrm{Cu}-\mathrm{Z}$ dissociation energies of $179.71,174.79$, and $174.01 \mathrm{kcal} / \mathrm{mol}$, respectively, such that the overall sequence becomes $\mathrm{M} 1<\mathrm{C} 2<\mathrm{M} 4<\mathrm{M} 2<$ I $<\mathrm{C} 1<\mathrm{A}<\mathrm{M} 3$. Indeed, the $\mathrm{Cu}^{+}$ion is most strongly bound in the $6 \mathrm{~T}$ rings of the zeolite network. As mentioned previously, the 6T ring of the ZSM-11 structure (M3) is also the most reactive position to the $\mathrm{Cu}$ cation and a relatively small reaction heat is required for an exchange at this location. These findings partially resemble the data reported previously by Nachtigallova et al. [31] for the $\mathrm{Cu}^{2+}$ ion which was observed to bind more strongly to the 6T-rings of an Al-containing MFI structure. Similar findings have been reported by Rejmak et al. [18] for the exchanged $\mathrm{Cu}^{+}$ions in an
Al-incorporated faujasite. As far as we know, however, the relatively similar preference of the copper ion for the intersection sites of ZSM-11 is a new finding. The relatively strong bindings offered by the intersection sites to the impregnating copper ion finds more importance when taking into consideration that this site constitutes a large portion of the available positions of the zeolite structure (Table 6). The di-coordinated $\mathrm{Cu}^{+}$ions at the intersection sites have a high accessibility and are expected to be involved in the catalytic activity of the copper-exchanged zeolite [28]. However, the overall behavior of the solid matrix as estimated from a population average of the energetic data lies between the values obtained for $\mathrm{M} 3-\mathrm{Cu}$ and $\mathrm{I}-\mathrm{Cu}$ when the exchange enthalpies are compared and would be closest to the corresponding values of $\mathrm{M} 2-\mathrm{Cu}, \mathrm{I}-\mathrm{Cu}$, and $\mathrm{C} 1-\mathrm{Cu}$ in terms of the binding energy. Therefore, the mentioned sites might be chosen as a representative of the whole material in possible required simplifications depending upon which energetic property has to be assessed.

All but one of the sites available in the ZSM-11 structure (M3) provide a weaker binding for $\mathrm{Cu}^{+}$than the alpha site (A). However, both the $\mathrm{Cu}^{+} / \mathrm{H}^{+}$exchange enthalpies of the A-Cu site $(126.17 \mathrm{kcal} / \mathrm{mol})$ and that of a typical ZSM11 matrix $(124.84 \mathrm{kcal} / \mathrm{mol})$ are interestingly higher than the exchange energies of $43.0-102.2 \mathrm{kcal} / \mathrm{mol}$ calculated for $\mathrm{Cu}^{2+}$ ions exchanged to H-ZSM-5 [31] but closer to other values reported earlier such as a $96.3-124.6 \mathrm{kcal} / \mathrm{mol}$ for $\mathrm{Cu}^{+}$in ZSM- 5 by Blint [46]. The observed differences can be only partially attributed to the oxidation state of the copper in the work by Nachtigallova et al. [31] which replaces two protons with a strongly bound $\mathrm{Cu}^{2+}$ ion as a $[\mathrm{Z}-\mathrm{O}]-\mathrm{Cu}-[\mathrm{O}-$ $Z]$ complex and, therefore, reduces the exchange energy with respect to that of a $\mathrm{Cu}^{+}$ion. The aliasing effect of the computational method employed is worth attention as well which calls for further theoretical research in this respect. However, the main source of difference might be the effect of framework type assuming that the effects of method and the cluster size are negligible.

The binding energies reported in Table 6 can also be compared against similar magnitudes from the literature including $482-715 \mathrm{kcal} / \mathrm{mol}$ for the optimized $\mathrm{Cu}^{2+}$ coordination in ZSM-5 [24], about $139 \mathrm{kcal} / \mathrm{mol}$ for $\mathrm{Cu}^{+}$ions in ZSM-5 [28], 109.6-136.9 kcal/mol for $\mathrm{Cu}^{+}$ions in ZSM-5 [110], $169.5 \mathrm{kcal} / \mathrm{mol}$ for $\mathrm{Cu}-\mathrm{Y}$ [14], 106.1-146.7 kcal/mol for $\mathrm{Cu}^{+}$binding in FER [29], and a $163.9 \mathrm{kcal} / \mathrm{mol}$ binding energy for $\mathrm{Cu}^{+}$in ZSM-5 [15]. As can be seen, all of the previously reported data for the binding energy of $\mathrm{Cu}^{+}$ion particularly the last report are very close to the range obtained here for the various sites of ZSM-11. The corresponding magnitudes reported by Groothaert et al. [24] for $\mathrm{Cu}^{2+}$ ions bound to the oxide surface of ZSM-11 with two Al atoms incorporated have been significantly larger than those of $\mathrm{Cu}^{+}$ion. Rejmak et al. [18] have also found that the strength of cation binding should increase with the number of $\mathrm{Al}$ atoms present in the 6T rings of a faujasite. These 
confirm our discussion just presented above to explain the source of differences in the energetic data.

Also worth noting is that the average of the energetic data for a Cu-ZSM-11 catalyst is slightly smaller than that of the alpha site from a Cu-ZSM-5 catalyst. It might be concluded with some caution that the chemical or geometrical nature of the available sites in ZSM-11 would only partially account for the experimentally observed higher sorption power and reactivity of the MEL structure in the decomposition of $\mathrm{NO}$ and $\mathrm{N}_{2} \mathrm{O}$ molecules with respect to those of Al-containing MFI zeolites (if can be compared on a sound basis). Then, it appears up to now that the main factor which plays the role in this privilege is the better accessibility of the reactant/template molecules to the available sites. However, the superior activity of $\mathrm{Cu}-\mathrm{ZSM}-11$ relative to $\mathrm{Cu}-\mathrm{ZSM}-5$ in direct $\mathrm{N}_{2} \mathrm{O}$ decomposition has been attributed to both a higher accessibility and a better reducibility of $\mathrm{Cu}^{+}$species, implying that the framework topologies of the zeolites would influence the reducibility of $\mathrm{Cu}^{+}$species present on the copper-ion-exchanged zeolites [55]. A more precise evaluation of the two catalysts requires, at least, a similar systematic study of the MFI zeolite to be implemented with the energy of binding or the exchange energy averaged over the available sites as it was conducted for MEL, however. Further works in the same line are then required to gain a more detailed and deeper insight into the mechanistic role of the active site for the design and development of selective catalysts.

\section{Conclusion}

This paper investigated the geometrical, electronic, and energetic properties of $\mathrm{Cu}^{+}$monoatomic centers in Cu-ZSM-11 catalysts using the cluster modeling approach through density functional theory. Total of 7 sites for $\mathrm{Cu}^{+}$exchange to $\mathrm{H}-\mathrm{ZSM}$ 11 were considered and compared with an alpha-site from an MFI structure. The coordination numbers differed from two to four, with the former observed at the intersections, the 4T-rings, and the basket-like positions of ZSM-11 and the latter in the other ring sites and cage-like locations. The HOMO-LUMO energy gaps of the copper-exchanged clusters fell into the range of 3.31-5.15 eV at the TD-BH\&HLYP/6-311+G* level. Overall, the $\mathrm{I}-\mathrm{Cu}$ and $\mathrm{M} 1-\mathrm{Cu}$ clusters were the highest polarizable sites and M4-Cu was found to be the most stable site as indicated from the HOMO-LUMO gaps. In total, the QTAIM results manifested closed-shell electrostatic interactions for all of the sites. The charge transfer varied from 0.10 e to $0.33 \mathrm{e}$ with the highest value belonging to the cage-like positions which provided weakly bounded tri- and tetra-coordinated planar configurations with the nearest-neighbor oxygen atoms of the surface. Excellent power-type correlations were observed between the electronic properties and the bond distances. The exchange enthalpy ranged from 108.93 to $141.14 \mathrm{kcal} / \mathrm{mol}$. The 6 T-ring was the most readily exchangeable site while the 4T-ring site was the least favorable thermodynamically. As far as the most accessible sites for a coming molecule are concerned, both $\mathrm{M} 3$ and I positions are adequately readily exchanged, however. The binding energy was found to alter in the range of $146.99-195.45 \mathrm{kcal} / \mathrm{mol}$. As revealed from the energetic data, the $\mathrm{Cu}^{+}$ion most strongly bound in the $6 \mathrm{~T}$ rings followed by the cages and the intersections of the zeolite matrix.

\section{Computational method}

The cluster modeling method was employed for the molecular simulations. As a common approach to mimic the influence and rigidity of the surrounding framework $[4,15,20,24,31,33$, 110-120], all of the dangling bonds at the boundaries of every cluster were terminated by link hydrogen atoms placed in the same bond direction as would be found in a perfect crystal for the next oxygen or silicon atom removed from the cluster. The boundary $\mathrm{H}$ atoms were placed at 0.960 and $1.550 \AA$ from the oxygen and silicon atoms, respectively, with the values determined from preliminary optimizations. In total, the size of the clusters ranged from a T5 to a T10 unit. Here, every cluster model incorporates an aluminum atom that requires a compensating ion on one of the adjacent oxygen atoms. The crystallographic data for the frameworks of ZSM-11 and ZSM-5 can be found elsewhere [121-122]. In addition to the exchange positions introduced in Fig. 1, a separate fragment from an MFI structure was also modeled for comparison. This cluster was taken from an alpha position - an effective 6T-ring on the wall of straight channel, formed by two interconnecting 5T-rings, and readily available to reagents - which appears to be of special interest with respect to catalytic actions $[17,20,24,119$ 120, 123-125]. The exchanged/compensating ion was taken here to be $\mathrm{a} \mathrm{Cu}^{+}$or an $\mathrm{H}^{+}$ion as the key element of the active site. These cluster models are adequate to explain the interactions of the metal ion with the oxide surface within a precise local picture of the active site [33, 126-127]. A two-step optimization procedure was used. At the first stage, all of the atoms in the cluster except the $\mathrm{Cu}$ ion, proton, and $\mathrm{Al}$ atom were fixed during the geometrical optimizations to simply represent the mechanical embedding of the solid matrix. At the second step, the nearest interacting oxygen atoms were also relaxed to include possible alterations in the skeletal vibrations due to the $\mathrm{Al}$ substitution or the $\mathrm{Cu}$ exchange.

The molecular geometries of the structures were optimized using the functional B3LYP method [86-87, 128] which has been reported to yield reliable data on both oxides and metal clusters $[4,23,129]$. The Pople's standard 6-31+G* basis set [130-133] was employed for all of the atoms. The single-point calculations were implemented with a larger basis set at B3LYP/6-311+G* [134] for improved energetic data. Calculations were also made with the M06/Def2TZVP method. The atomic charges for the optimized structures were obtained through the natural bond orbital (NBO) calculations. The energetic calculations were performed on the zeolite surface $\left(\mathrm{Z}^{-}\right)$excluding the metal ion $\left(\mathrm{Cu}^{+}\right)$to allow for an estimation of the binding energy $\left(\Delta E_{\mathrm{b}}\right)$ of $\mathrm{Cu}^{+}$at 
every site [24], which was defined as the energy of the following reaction with a negative sign $[18,29,110]$ :

$$
\mathrm{Cu}-\mathrm{Z} \rightarrow \mathrm{Cu}^{+}+\mathrm{Z}^{-}
$$

The $\mathrm{Cu}^{+} / \mathrm{H}^{+}$exchange enthalpy $\left(\Delta H_{\mathrm{ex}}\right)$ was defined as the enthalpy change of the reaction [31]:

$$
\mathrm{H}-\mathrm{Z}+\mathrm{Cu}^{+} \rightarrow \mathrm{Cu}-\mathrm{Z}+\mathrm{H}^{+}
$$

where symbols $\mathrm{Cu}-\mathrm{Z}$ and $\mathrm{H}-\mathrm{Z}$ refer to the copper-exchanged cluster and the acidic surface of the zeolite, respectively.

The NBO population [135] and the QTAIM [98-99, 136-139] assessments were done at the B3LYP/6-311+G* level of theory. The calculations were implemented using NWChem 6.5 [140] and Multiwfn 3.3.8 [141]. The graphical outputs were drawn by the molecular visualization program Mercury 3.3 [142-145].

\section{References}

1. Smeets, P. J., et al. Inorganic Chemistry. 2010, 49, 3573-3583.

2. Delabie, A., et al. European Journal of Inorganic Chemistry. 2002, 2002, 515-530.

3. Pidko, E. A.; Hensen, E. J. M.; van Santen, R. A. Proceedings of the Royal Society A: Mathematical, Physical and Engineering Science. 2012, 468, 2070-2086.

4. Ferullo, R. M., et al. Journal of Molecular Structure: THEOCHEM. 2006, 769, 217-223.

5. Woertink, J. S., et al. Proc Natl Acad Sci USA. 2009, 106, 1890818913.

6. Gao, Y.; Kispert, L. D. Dalton Transactions. 2014, 43, 6221-6228.

7. Davidová, M., et al. The Journal of Physical Chemistry B. 2004, 108, 13674-13682.

8. Solans-Monfort, X., PhD Dissertation, in: Departament de Quimica, Universitat Autònoma de Barcelona, Bellaterra, 2003.

9. Sengupta, D., et al. Catal Lett. 2001, 74, 193-199.

10. Kim, S. J., et al. Journal of Nanoscience and Nanotechnology. 2010, 10, 147-157.

11. Kustova, M. Y., et al. Applied Catalysis B: Environmental. 2006, 67, 60-67.

12. Mitra, S., MSc Thesis, in: Department of Chemical Engineering, National Institute of Technology, Rourkela, 2014.

13. Sierraalta, A.; Añez, R.; Brussin, M.-R. Journal of Catalysis. 2002, 205, 107-114.

14. Sung, C.-Y., et al. The Journal of Physical Chemistry C. 2011, 116, 3561-3575.

15. Treesukol, P.; Limtrakul, J.; Truong, T. N. The Journal of Physical Chemistry B. 2001, 105, 2421-2428.

16. Ahmed, A. H. Journal of Applied Sciences Research. 2007, 3, 1663-1670.

17. Pidko, E.; Kazansky, V. Physical Chemistry Chemical Physics. 2005, 7, 1939-1944.

18. Rejmak, P.; Sierka, M.; Sauer, J. Physical Chemistry Chemical Physics. 2007, 9, 5446-5456.

19. Berthomieu, D., et al. The Journal of Physical Chemistry B. 2001, 105, 1149-1156.
20. Broclawik, E., et al. Catalysis Today. 2002, 75, 353-357.

21. Bulanek, R., et al. Physical Chemistry Chemical Physics. 2004, 6 , 2003-2007.

22. Davidová, M., et al. The Journal of Physical Chemistry B. 2003, 107, 2327-2332.

23. Ferullo, R. M.; Castellani, N. J. Journal of Molecular Catalysis A: Chemical. 2004, 221, 155-162.

24. Groothaert, M. H., et al. Physical Chemistry Chemical Physics. 2003, 5, 2135-2144.

25. Hagelberg, F.; Xiao, C.; Lester, W. A. Physical Review B. 2003, 67, 035426-1-035426-9.

26. Kamarudin, K. S. N., PhD Dissertation, Universiti Teknologi Malaysia, 2009.

27. Kustova, M. Y., et al. Catalysis Communications. 2006, 7, 705-708.

28. Morpurgo, S.; Moretti, G.; Bossa, M. Theor Chem Account. 2012, 131, 1-12.

29. Nachtigall, P.; Davidová, M.; Nachtigallová, D. The Journal of Physical Chemistry B. 2001, 105, 3510-3517.

30. Nachtigall, P.; Nachtigallová, D.; Sauer, J. The Journal of Physical Chemistry B. 2000, 104, 1738-1745.

31. Nachtigallova, D.; Nachtigall, P.; Sauer, J. Physical Chemistry Chemical Physics. 2001, 3, 1552-1559.

32. Pierloot, K., et al. Physical Chemistry Chemical Physics. 2001, 3, 2174-2183.

33. Pietrzyk, P. The Journal of Physical Chemistry B. 2005, 109, 10291-10303.

34. Ramstad, A. L.; Mikkelsen, Ø. Journal of Molecular Structure. 2004, 697, 109-117.

35. Rice, M. J.; Chakraborty, A. K.; Bell, A. T. The Journal of Physical Chemistry B. 2000, 104, 9987-9992.

36. Rice, M. J.; Chakraborty, A. K.; Bell, A. T. Journal of Catalysis. 2000, 194, 278-285.

37. Sierraalta, A.; Bermudez, A.; Rosa-Brussin, M. Journal of Molecular Catalysis A: Chemical. 2005, 228, 203-210.

38. Šponer, J. E., et al. The Journal of Physical Chemistry B. 2001, $105,8285-8290$.

39. Rodriguez-Santiago, L., et al. Journal of the American Chemical Society. 1998, 120, 1545-1551.

40. Sengupta, D., et al. Catal Lett. 1999, 61, 179-186.

41. Schneider, W. F., et al. The Journal of Physical Chemistry B. 1998, 102, 3692-3705.

42. Tajima, N., et al. Physical Chemistry Chemical Physics. 1999, 1, 3823-3830.

43. Hass, K. C.; Schneider, F. W. Physical Chemistry Chemical Physics. 1999, 1, 639-648.

44. Schneider, W. F., et al. The Journal of Physical Chemistry B. 1997, 101, 4353-4357.

45. Goodman, B. R., et al. The Journal of Physical Chemistry B. 1999, 103, 10452-10460.

46. Blint, R. J. The Journal of Physical Chemistry. 1996, 100, 1951819524.

47. Yokomichi, Y., et al. The Journal of Physical Chemistry. 1996, 100, 14424-14429.

48. Ramprasad, R., et al. The Journal of Physical Chemistry B. 1997, 101, 1940-1949.

49. Schneider, W. F., et al. The Journal of Physical Chemistry. 1996, 100, 6032-6046.

50. Hass, K. C.; Schneider, W. F. The Journal of Physical Chemistry. 1996, 100, 9292-9301. 
51. Rice, M. J.; Chakraborty, A. K.; Bell, A. T. The Journal of Physical Chemistry A. 1998, 102, 7498-7504.

52. Jacobs, P. A.; Martens, J. A. Synthesis of High-Silica Aluminosilicate Zeolites. Amsterdam: Elsevier, 1987.

53. Fyfe, C. A., et al. Journal of the American Chemical Society. 1989, $111,2470-2474$.

54. Čejka, J.; Corma, A.; Zones, S. Zeolites and Catalysis: Synthesis, Reactions and Applications. Weinheim: Wiley, 2010.

55. Xie, P., et al. Microporous and Mesoporous Materials. 2014, 191, 112-117.

56. Kustova, M. Y.; Hasselriis, P.; Christensen, C. H. Catal Lett. 2004, 96, 205-211.

57. Ghashghaee, M.; Ghambarian, M.; Azizi, Z. Struct Chem. 2016, 27, 467-475.

58. Sánchez, M., et al. Microporous and Mesoporous Materials. 2015, 203, 91-99.

59. Gonzalez, G., et al. Microporous and Mesoporous Materials. 2009, 121, 26-33.

60. Auerbach, S. M.; Carrado, K. A.; Dutta, P. K. Handbook of Zeolite Science and Technology. New York: Marcel Dekker, 2003.

61. van der Gaag, F. J., 1987.

62. Flanigen, E. M. Pure \& Appl. Chem. 1980, 52, 2191-2211.

63. Čejka, J.; Kubička, D., in: Kirk-Othmer Encyclopedia of Chemical Technology, John Wiley \& Sons, Hoboken, New Jersey, 2010, 1-30.

64. Xu, R., et al. Chemistry of Zeolites and Related Porous Materials: Synthesis and Structure. Singapore: John Wiley \& Sons, 2007.

65. Weitkamp, J.; Hunger, M. Stud. Surf. Sci. Catal. 2007, 168, 787-835.

66. Guisnet, M.; Gilson, J.-P. Zeolites for Cleaner Technologies. London: Imperial College Press, 2002.

67. Ghambarian, M., et al., in: 3rd International Congress of Chemistry and Chemical Engineering, Tehran, Iran, 2016, 292-299.

68. Ghashghaee, M., et al., in: 3rd International Congress of Chemistry and Chemical Engineering, Tehran, Iran, 2016, 188-195.

69. Sastre, G.; Corma, A. Journal of Molecular Catalysis A: Chemical. 2009, 305, 3-7.

70. Derouane, E. G. Chemical Physics Letters. 1987, 142, 200-204.

71. Boekfa, B., et al. The Journal of Physical Chemistry C. 2010, 114, 15061-15067.

72. Derouane, E. G.; Chang, C. D. Microporous and Mesoporous Materials. 2000, 35-36, 425-433.

73. Zicovich-Wilson, C. M.; Corma, A.; Viruela, P. The Journal of Physical Chemistry. 1994, 98, 10863-10870.

74. Corma, A. Journal of Catalysis. 2003, 216, 298-312.

75. Wongthong, P., Vol. MSc, Kasetsart University, 2005.

76. Arifin, R., et al. The Journal of Physical Chemistry C. 2015, 119, 3210-3216.

77. Eun Jee, S.; McGaughey, A. J. H.; Sholl, D. S. Molecular Simulation. 2009, 35, 70-78.

78. García-Sánchez, A.; Dubbeldam, D.; Calero, S. The Journal of Physical Chemistry C. 2010, 114, 15068-15074.

79. Krishna, R.; van Baten, J. M. The Journal of Physical Chemistry C. 2010, 114, 18017-18021.

80. Handzlik, J.; Grybos, R.; Tielens, F. The Journal of Physical Chemistry C. 2013, 117, 8138-8149.

81. Ghambarian, M.; Azizi, Z.; Ghashghaee, M. Computational Materials Science. 2016, 118, 147-154.

82. Balar, M.; Azizi, Z.; Ghashghaee, M. Journal of Nanostructure in Chemistry. 2016, 6, 365-372.

83. Göltl, F.; Hafner, J. The Journal of Chemical Physics. 2012, 136, 064501-1-064501-17.
84. Göltl, F.; Hafner, J. The Journal of Chemical Physics. 2012, 136, 064503.

85. Zhang, G.; Musgrave, C. B. The Journal of Physical Chemistry A. 2007, 111, 1554-1561.

86. Lee, C.; Yang, W.; Parr, R. G. Physical Review B. 1988, 37, 785-789.

87. Becke, A. D. The Journal of Chemical Physics. 1993, 98, 5648-5652.

88. Gázquez, J. L.; Cedillo, A.; Vela, A. The Journal of Physical Chemistry A. 2007, 111, 1966-1970.

89. Orozco-Valencia, Á. U.; Vela, A. Journal of the Mexican Chemical Society. 2012, 56, 294-301.

90. Li, K.; Li, M.; Xue, D. Nanoscale Research Letters. 2012, 7, 6.

91. Morell, C., et al. Physical Chemistry Chemical Physics. 2014, 16, 26832-26842.

92. Fukui, K.; Yonezawa, T.; Shingu, H. The Journal of Chemical Physics. 1952, 20, 722-725.

93. Pearson, R. G. Journal of Chemical Education. 1987, 64, 561-567.

94. Parr, R. G.; Weitao, Y. Density-Functional Theory of Atoms and Molecules. New York: Oxford University Press, 1989.

95. Vektariene, A.; Vektaris, G.; Svoboda, J. ARKIVOC. 2009, 7, 311-329.

96. Gopalakrishnan, S. B.; Kalaiarasi, T.; Subramanian, R. Journal of Computational Methods in Physics. 2014, 2014, 623235-1623235-6.

97. Aihara, J.-i. The Journal of Physical Chemistry A. 1999, 103, 7487-7495

98. Bader, R. F. W. Atoms in Molecules: A Quantum Theory. USA: Oxford University Press, 1994.

99. Matta, C. F.; Boyd, R. J. The Quantum Theory of Atoms in Molecules: From Solid State to DNA and Drug Design. Weinheim: Wiley-VCH Verlag GmbH \& Co. KGaA, 2007.

100. Lopez, N., et al. Chemical Physics Letters. 1998, 294, 611-618.

101. Lopez, N.; Illas, F.; Pacchioni, G. The Journal of Physical Chemistry B. 1999, 103, 1712-1718.

102. Padilla-Campos, L. Journal of the Chilean Chemical Society. 2005, 50, 745-752.

103. Burda, J. V.; Shukla, M. K.; Leszczynski, J. J Mol Model. 2005, 11, 362-369.

104. Halbert, S.; Gerard, H. New Journal of Chemistry. 2015, 39, 5410-5419.

105. Gibbs, G. V., et al. The Journal of Physical Chemistry B. 2003, 107, 12996-13006.

106. Gibbs, G. V., et al. zkri. 2008, 223, 1-40.

107. Gálvez, O.; Gómez, P. C.; Pacios, L. F. The Journal of Chemical Physics. 2003, 118, 4878-4895.

108. Lü, R., et al. Bulletin of the Korean Chemical Society. 2013, 34, 1814-1822.

109. Gibbs, G. V., et al. The Journal of Physical Chemistry B. 2005, 109, 21788-21795.

110. Nachtigallova, D., et al. Physical Chemistry Chemical Physics. 1999, 1, 2019-2026.

111. Aleksandrov, H. A.; Vayssilov, G. N.; Rösch, N. Journal of Molecular Catalysis A: Chemical. 2006, 256, 149-155.

112. Pidko, E. A.; van Santen, R. A. The Journal of Physical Chemistry C. 2007, 111, 2643-2655.

113. Yakovlev, A., et al. Catal Lett. 2000, 70, 175-181.

114. Yang, G., et al. Journal of Molecular Catalysis A: Chemical. 2005, 237, 36-44.

115. Dědeček, J., et al. The Journal of Physical Chemistry C. 2009, 113, 1447-1458.

116. Lesthaeghe, D., et al. Chem CatChem. 2011, 3, 208-212. 
117. Wesolowski, T. A.; Goursot, A.; Weber, J. Journal of Chemical Physics. 2001, 115, 4791-4797.

118. Zhang, B., et al. Journal of Environmental Sciences. 2011, 23, 681-686.

119. Zhidomirov, G. M., et al. International Journal of Quantum Chemistry. 2004, 100, 489-494.

120. Shubin, A. A., et al. Catal Lett. 2003, 90, 137-142.

121. Terasaki, O., et al. Chemistry of Materials. 1996, 8, 463-468.

122. van Koningsveld, H.; Jansen, J. C.; van Bekkum, H. Zeolites. 1990, 10, 235-242.

123. Zhidomirov, G. M.; Shubin, A. A.; van Santen, R. A., in: Computer Modelling of Microporous Materials, Catlow, C. R. A., van Santen, R. A., and Smit, B. Eds., WILEY-VCH Verlag, 2005, 201-241.

124. Heyden, A., PhD Dissertation, in: Department of Chemical Reaction Engineering, Hamburg University of Technology, Hamburg, 2005.

125. Mikhailov, M. N., et al. Microporous and Mesoporous Materials. 2007, 104, 145-150.

126. Pietrzyk, P., et al. The Journal of Physical Chemistry B. 2003, 107, 6105-6113.

127. Chester, A. W.; Derouane, E. G. Zeolite Characterization and Catalysis: A Tutorial. Dordrecht: Springer, 2009.

128. Becke, A. D. Physical Review A. 1988, 38, 3098-3100.

129. Yumura, T., et al. Physical Chemistry Chemical Physics. 2010, 12, 2392-2400.

130. Hariharan, P. C.; Pople, J. A. Molecular Physics. 1974, 27, $209-214$.
131. Francl, M. M., et al. The Journal of Chemical Physics. 1982, 77, 3654-3665.

132. Clark, T., et al. Journal of Computational Chemistry. 1983, 4, 294-301.

133. Frisch, M. J.; Pople, J. A.; Binkley, J. S. The Journal of Chemical Physics. 1984, 80, 3265-3269.

134. Kendall, R. A.; Dunning, T. H.; Harrison, R. J. The Journal of Chemical Physics. 1992, 96, 6796-6806.

135. Glendening, E., et al. Theoretical Chemistry Institute, University of Wisconsin, Madison, WI. 1996,

136. Rodríguez, J. I., et al. Chemical Physics Letters. 2009, 472, 149-152.

137. Bader, R. F. W. Chemical Reviews. 1991, 91, 893-928.

138. Bader, R. F. W. Monatshefte für Chemie. 2005, 136, 819-854.

139. Bader, R. F. W. Accounts of Chemical Research. 1975, 8, 34-40.

140. Valiev, M., et al. Computer Physics Communications. 2010, 181, 1477-1489.

141. Lu, T.; Chen, F. Journal of Computational Chemistry. 2012, 33, 580-592.

142. Bruno, I. J., et al. Acta Crystallographica Section B. 2002, 58, 389-397.

143. Macrae, C. F., et al. Journal of Applied Crystallography. 2008, 41, 466-470.

144. Macrae, C. F., et al. Journal of Applied Crystallography. 2006, 39, 453-457.

145. Taylor, R.; Macrae, C. F. Acta Crystallographica Section B. 2001, 57, 815-827. 


\title{
Policy Proposal for Metals Speciation in Tailings Contaminated Soils: A Case Study in Chihuahua, Mexico
}

\author{
Irma Cruz Gavilán García, ${ }^{1 *}$ Georgina Fernández Villagómez, ${ }^{2}$ Alejandro Menchaca Pérez, ${ }^{1}$ \\ Luis Adrian Barraza Torres ${ }^{2}$ and Arturo Gavilán García ${ }^{3}$
}

1 Environmental Management Unit, Faculty of Chemistry, National Autonomous University of Mexico, Av. Universidad 3000, C.P. 04510, Del. Coyoacán, Ciudad de México, México.

2 Faculty of Engineering, National Autonomous University of Mexico, Av. Universidad 3000, C.P. 04510, Del. Coyoacán, Ciudad de México, México.

3 National Institute of Ecology and Climate Change, Ministry of Environment and Natural Resources, Periférico 5000, Col. Insurgentes-Cuicuilco, C.P. 04530, Ciudad de México, México.

* Corresponding author: irmac@unam.mx

Received August 31 $1^{\text {st }}, 2016$; Accepted December 2 ${ }^{\text {nd }}, 2016$.

\begin{abstract}
This work is focused in studying the inclusion of chemical speciation in the characterization of mining tailings in Mexican regulation with a case study in Parral, Chihuahua, Mexico. In this site, high concentration of lead and arsenic in tailings located in the surroundings represent a high concern to the local population. The total concentration of $\mathrm{Pb}$ in the samples ranged from $78.03 \pm 2.67$ to $5748 \pm 263.63$ $\left[\mathrm{mg} \mathrm{kg}^{-1}\right]$ and from $5.49 \pm 0.43$ to $509.84 \pm 40.18\left[\mathrm{mg} \mathrm{kg}^{-1}\right]$ for As. Chemical speciation was tested for samples that exceeded the limits of the Mexican Regulation using sequential extractions proposed by the Bureau Community of Reference (BCR) to obtain the distribution of lead and arsenic in four different fractions. The set of extractions consisted in the extractable/exchangeable fraction $(\mathrm{F} 1)$, the reducible fraction (F2), the metals bound to organic matter and sulfides (F3) those under oxidizing conditions, and the residual fraction (RF). The results show that $70 \%$ of lead is found in F1 and F2 fractions while $20 \%$ is found in F3 fraction. In case of arsenic, $60 \%$ is found in residual fraction, $25 \%$ in fraction F3 and less than 15\% in fractions F1 and F2.

Keywords: Arsenic; lead; atomic absorption spectrometry; speciation; mining waste.
\end{abstract}

\section{Introduction}

Mining is one of the economic activities that have greatly contributed to the economic development of Mexico. The mining industry is mostly related to metal extraction and is mainly engaged in the production of copper, zinc, silver and lead. In Mexico, there have been various regions with huge mining industry such as Southern Part of the State of Chihuahua where mining activities date from 1567 [1].

In the city of Parral, in the State of Chihuahua, mining brought not only prosperity, economic growth and urban development, but also an environmental latent problem since the beginning of the operation of La Prieta mine. With an estimated production of 1,500 ton a day of pure mineral, soil wastes
Resumen. Este trabajo se enfoca en el estudio de la inclusión de la especiación química en la caracterización de los residuos mineros en la regulación mexicana con un estudio de caso en Parral, Chihuahua, México. En este sitio, alta concentración de plomo y arsénico en los jales ubicados en los alrededores representan una gran preocupación para la población local. La concentración total de $\mathrm{Pb}$ en las muestras osciló entre 78,03 $\pm 2,67$ a $5748 \pm 263,63\left[\mathrm{mg} \mathrm{kg}^{-1}\right]$ y de $5,49 \pm 0,43$ a $509,84 \pm 40,18\left[\mathrm{mg} \mathrm{kg}^{-1}\right]$ para As. Se aplicó la especiación química en las muestras que excedieron los límites de la regulación mexicana mediante extracciones secuenciales propuestos por la Oficina Boureaus de Referencia (BCR) para obtener la distribución de plomo y arsénico en cuatro fracciones diferentes. El conjunto de extracciones consistió en la fracción extraíble/intercambiable (F1), la fracción reducible (F2), los metales unidos a materia orgánica y sulfuros (F3) aquellos en condiciones oxidantes, y la fracción residual (RF). Los resultados muestran que $70 \%$ de plomo se encuentra en las fracciones F1 y F2, mientras que $20 \%$ se encuentra en la fracción F3. Para el caso de arsénico, $60 \%$ se encuentra en la fracción residual, $25 \%$ en la fracción F3 y menos del 15\% se distribuye en las fracciones F1 y F2.

Palabras clave: Arsénico; plomo; espectrometría de absorción atómica, especiación, residuos mineros.

have been generated to date covering an area of 80 hectares approximately [2].

The town of Hidalgo del Parral is located in the south of the State of Chihuahua, between parallels $26^{\circ} 51^{\prime}$ and $27^{\circ} 23^{\prime}$ North Latitude; the meridian $105^{\circ} 23^{\prime}$ and $105^{\circ} 59^{\prime}$ 'West Longitude, and an altitude between 1,300-2,400 m. Its limits are to the north with the Municipalities of Valle de Zaragoza and Allende, to the east with the municipality of Allende, to the south with the municipalities of Allende, Matamoros, Santa Barbara and San Francisco del Oro and to the west with the municipalities of San Francisco del Oro, Huejotitán and Valle de Zaragoza. It covers $0.8 \%$ of the state's area; it covers an area of $1,751 \mathrm{~km}^{2}$, which represents $0.71 \%$ of the state area. 
Its climate is classified as semi- humid and warm, with a maximum temperature of $36{ }^{\circ} \mathrm{C}$ and a minimum of $12{ }^{\circ} \mathrm{C}$. The annual average precipitation is $489 \mathrm{~mm}$ with an average of 72 rainy days and a relative humidity of $48 \%$. The prevailing winds come from the southwest [3].

The deficiency of the mineral extraction processes used in the mid-seventeenth century [4] caused the change of methodology to selective flotation resulting in the generation of large volumes of tailings, which is estimated to have been accumulated to date up to $19,527,678 \mathrm{~m}^{3}$ [5].

Previous studies in the area of Parral show the presence of lead and arsenic in soil (Fig. 1), exceeding the limits set by national and international organizations, which suggests that the tailings from the La Prieta mine is one of the major emission sources the metals $[6,7]$. Other studies have found heavy metal contamination in water bodies in the region from mining contamination $[8,9]$.

In order to determine the bioavailability of the $\mathrm{Pb}$ and $\mathrm{As}$ in tailing contaminated soil, it is important to determine the chemical species of them in order to establish its mobility.

The BCR method (Community Bureau of Reference) [10] is useful to determine the bioavailability of a metal at risk of being toxic to the environment based on sequential extractions, from which each sample represents the distribution of the metal and consist in: interchangeable/soluble fraction (F1), reducible fraction (F2), oxidizable fraction (F3) and residual fraction (FR).

The aim of this study is to determine the $\mathrm{Pb}$ and $\mathrm{As}$ chemical species in soil samples in order to provide elements for policy making based on the concentration levels in Parral, Chihuahua respect to the official national stndard [11].

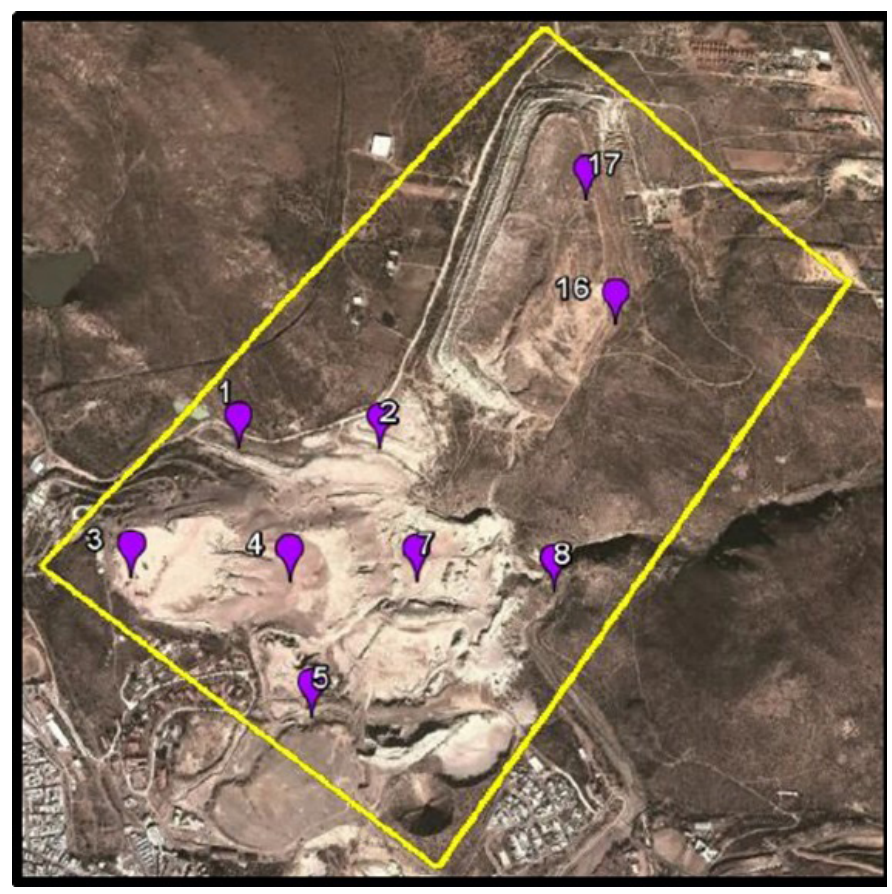

Figure 1. Geographic location of tailing contaminated soil in Hidalgo del Parral, Chihuahua [4]

\section{Materials and methods}

\subsection{Soil sampling and preparation}

Sampling points were selected according to the Mexican Technical Standard Guideline [12], which establishes the specifications for the collection and handling of samples, to allow the characterization of tailings contaminated soils in the study site, through the identification and quantification of metals and metalloids, the exploratory surface sampling was designed considering a confidence interval of $95 \%$ for a total of 19 georeferenced samples (Fig. 2). Sampling considered field measurements of parameters such as electrical conductivity, $\mathrm{pH}$, temperature at $30 \mathrm{~cm}$ depth, relative humidity and wind speed. Transportation of tailings contaminated soil samples to the laboratory was done in low-density polyethylene bags.

Lead and arsenic total content was determined by digestion with aqua regia. One gram of sample was weighted into the reaction vessel, and then $7.5 \mathrm{~mL}$ of $12.0 \mathrm{~mol} \mathrm{~L}^{-1} \mathrm{HCl}$ followed by $2.5 \mathrm{~mL}$ of $15.8 \mathrm{~mol} \mathrm{~L}^{-1} \mathrm{HNO}_{3}$, drop by drop, to reduce foaming, was added. The temperature of the reaction mixture was slowly raised until $85^{\circ} \mathrm{C}$ until reflux conditions were reached and maintained for $1 \mathrm{~h}$. After cooling the reaction vessel to room temperature the digests were filtered through Whatman No. 541 filter paper into $50 \mathrm{~mL}$ volumetric flasks, the insoluble residue onto the filter paper was washed with a $0.5 \mathrm{~mol} \mathrm{~L}^{-1} \mathrm{HNO}_{3}$ and the volumetric flask was filled with $0.5 \mathrm{~mol} \mathrm{~L}^{-1} \mathrm{HNO}_{3}$.

\subsection{Granulometric study of samples from the site under study}

A fraction of the samples, about $200 \mathrm{~g}$ each, were sieved for a granulometric study (Beckman Coulter LS Particle Size

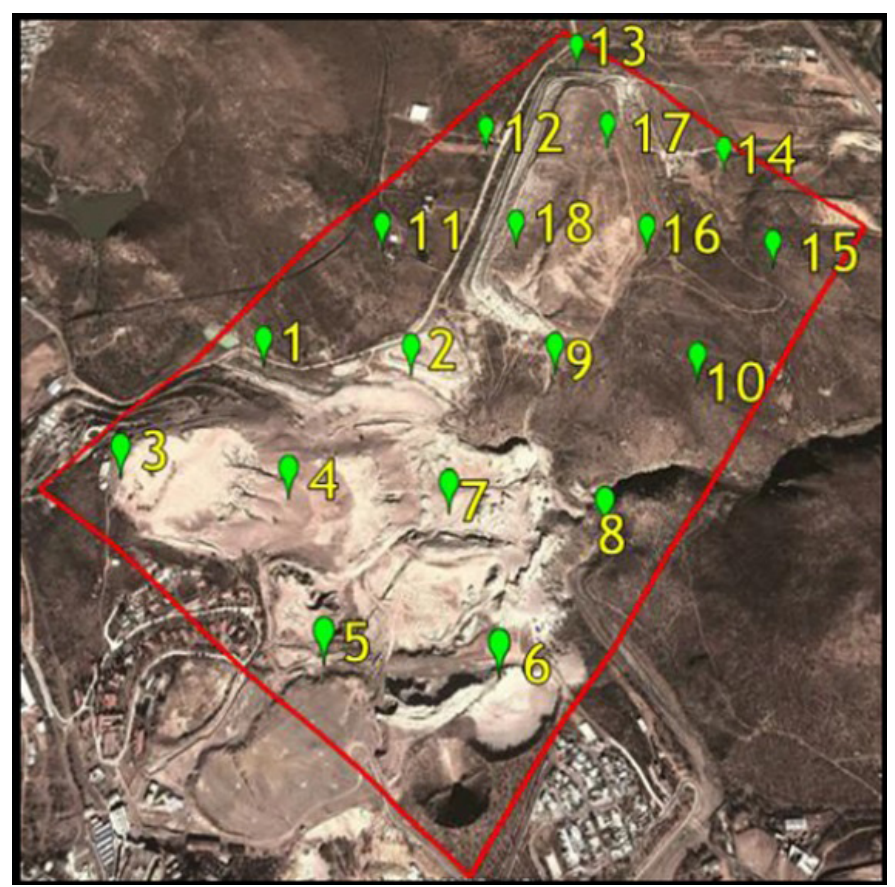

Figure 2. Space distribution of sampling points in the study area. 
Analyzer). This study provides a value of the particle size which are essential because it influences in the rate of oxidation of the mineral, such that it is favored when this is finely divided, that is, the greater the surface exposed to the reaction medium if recording has fine particles that exist, it is more likely that minerals or potentially toxic elements can be released more easily to the environment, however if the particles are of larger diameter, this probability decreases slightly [13]. Some samples were selected to determine the grain diameter of mining waste present in the study area. This selection was based in points that had a higher concentration of lead and arsenic, as well as a low value (Fig. 3).

\subsection{Apparatus}

A Thermo Scientific (Super-Nuova Multi-Place) heating plate equipped with a thermocouple thermometer was used for aqua regia open digestion method (USEPA 3050B). Lead and arsenic were determined in digests and extracts using a Perkin Elmer 3100A spectrometer and a Perkin Elmer Analyst 100 spectrometer equipped with a MHS-10 hydride system.

\subsection{Standards and Reagents}

All the solutions were prepared with de-ionized water 18 $\mathrm{M} \Omega \cdot \mathrm{cm}$, Millipore Milli-Q system. Arsenic and lead stock solution contains $1000 \mu \mathrm{g} / \mathrm{mL}$ (High-Purity Standards). These stock solutions were kept at $4{ }^{\circ} \mathrm{C}$ in darkness. More dilute solutions for the analysis were prepared daily for each analysis.

Nitric acid $\left(\mathrm{HNO}_{3}\right.$, Baker, Instra-analysed, $\left.70 \%\right)$ and hydrochloric acid ( $\mathrm{HCl}$, Baker, Instra-analysed, 36.5-38\%) were used for the aqua regia digestion.

\subsection{Storage and preparation of soils samples for total concentration analysis}

Sample preparation involves the following steps: (1) drying, (2) homogenizing and sieving, and (3) storage. The samples were digested with a mixture of aqua regia (nitric acid: hydrochloric acid in 1:3) [14].

\subsection{Analytical methods}

Lead and Arsenic concentrations in digests and extracts were determined using Flame Atomic Absorption Spectroscopy and Hydride Generation-Atomic Absorption Spectroscopy respectively $[15,16]$. For the measurement of $\mathrm{Pb}$ and As, hollow cathode lamps operated at $10 \mathrm{~mA}$ and a $283 \mathrm{~nm}$ wavelength, and $19 \mathrm{~mA}$ and a $193.7 \mathrm{~nm}$ wavelength were used respectively; the spectral band was $0.7 \mathrm{~nm}$ for $\mathrm{Pb}$ and $2.0 \mathrm{~nm}$ for As. Concentration of metals was obtained by the standard calibration technique.

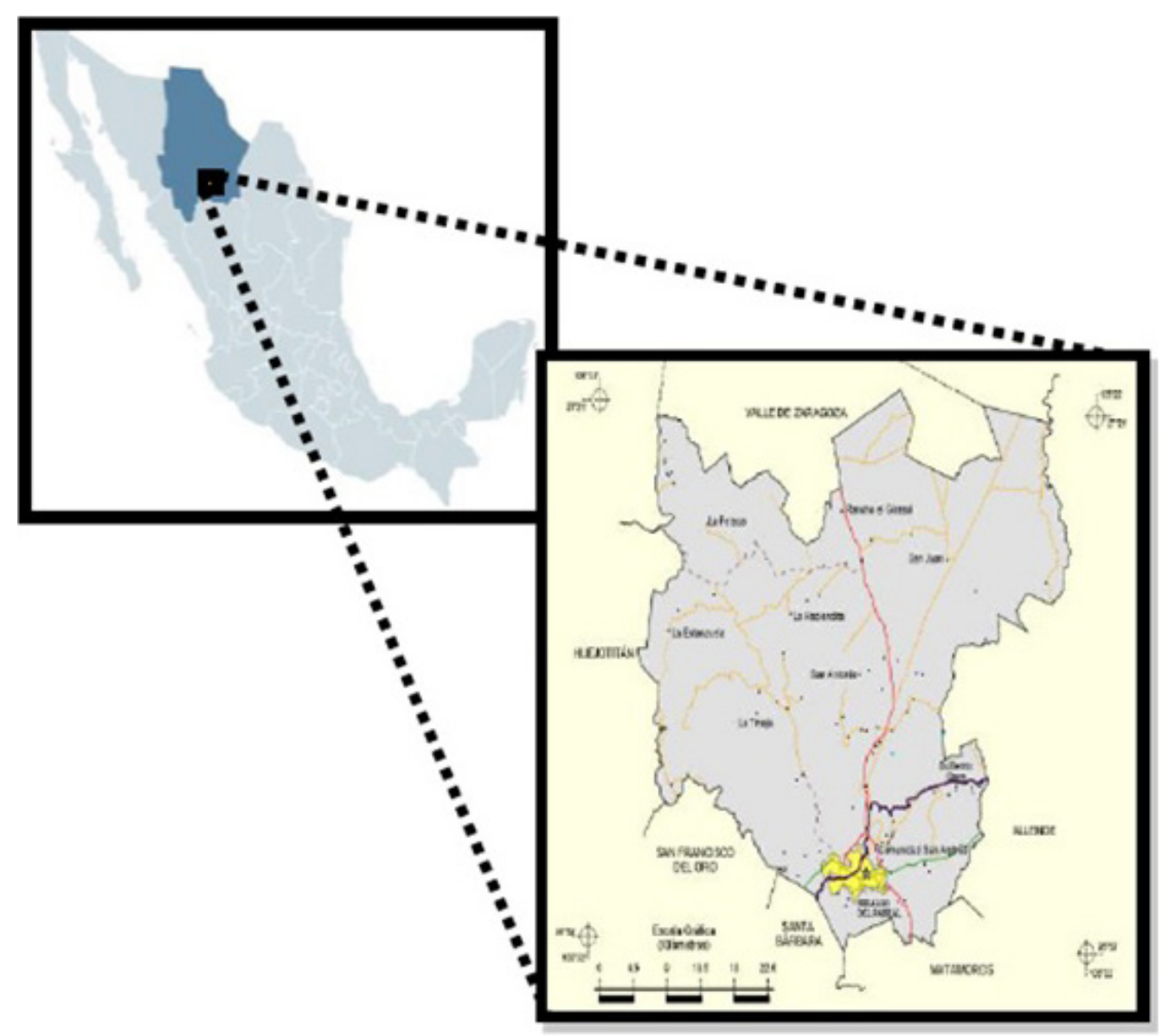

Figure 3. Sampling points for the granulometric study. 
To calculate the limit of detection (LOD) and the limit of quantification (LOQ), three curves were prepared, obtaining the standard deviation of the intercept $(\mathrm{Sb})$ and average of the slope. To evaluate the linear range, a calibration curve was prepared in the concentration range of 5 to $50 \mathrm{ng} / \mathrm{L}$ for arsenic and 5 to $30 \mathrm{mg} / \mathrm{L}$ for lead. Calibration sensitivity was determined by using the slope of the calibration curve. The accuracy of the method was evaluated as percentage of recovery by adding known amounts of arsenic and lead standard before the process of digestion and extraction to a blank sample. All samples were analyzed in triplicate. The results are expressed as mean values with standard deviations (SD) as a measure of dispersion (average $\pm \mathrm{SD}$ ).

\subsection{Sequential Extraction Procedure}

The sequential extraction was carried out according to the BCR (Community Bureau of Reference of the European Community) three-step procedure [10]. The method determines four well defined geochemical fractions of metals in soils and sediments: acid-soluble/exchangeable fraction (F1), reducible fraction (F2), oxidizable fraction (F3), and residual fraction (RF) [17]. Extractions were performed using the reagents given in section 2.4.

Extracting reagents were: acetic acid $\left(\mathrm{CH}_{3} \mathrm{CO}_{2} \mathrm{H}\right.$ Sigma-Aldrich 99.7\%), hydroxylamine hydrochloride $\left(\mathrm{NH}_{2}-\mathrm{OH}\right.$ $\mathrm{HCl}$ J. T. Baker), hydrogen peroxide $\left(\mathrm{H}_{2} \mathrm{O}_{2}\right.$ J.T. Baker $\left.30 \%\right)$ and ammonium acetate $\left(\mathrm{CH}_{3} \mathrm{CO}_{2} \mathrm{NH}_{4}\right.$ J.T. Baker). Hydride-generating reagents were: sodium borohydride $\left(\mathrm{NaBH}_{4}\right.$ tablets, Fluka, purity $>97 \%$ at $3 \%$ in $1 \% \mathrm{NaOH}$ ); $\mathrm{HCl} 15 \%$ were used for pre-reduction in the determination of arsenic after aqua regia leaching.

Step 1 (acid extractable/exchange fraction-bound to carbonates):

A total of $40 \mathrm{~mL}$ of acetic acid $0.11 \mathrm{~mol} \mathrm{~L}^{-1}$ was added to $0.5 \mathrm{~g}$ air-dried sample and shaken for $16 \mathrm{~h}$. The mixture was centrifuged to separate the extract from the residue using a centrifuge (Labnet Hermle) at $3000 \mathrm{rpm}$ for $15 \mathrm{~min}$ and the supernatant solution filtered through Whatman No. 40 filter paper, rinsed with deionized water, hand shaken and stored in acid rinsed polypropylene tubes for further analysis. The residue was washed with $20 \mathrm{~mL}$ of distilled water by shaking for $20 \mathrm{~min}$, centrifuged and the washings discarded.
Step 2 (reducible fraction-bound to Fe/Mn oxides):

A total of $40 \mathrm{~mL}$ of hydroxylammonium chloride $0.5 \mathrm{~mol}$ $\mathrm{L}^{-1}$, adjusted with nitric acid to $\mathrm{pH} 2$, was added to the residue from step 1 and the extraction performed as above.

Step 3 (oxidizable fraction-bound to organic matters and sulfides):

The residue from step 2 was treated twice with $8.8 \mathrm{~mol} \mathrm{~L}^{-1}$ hydrogen peroxide, first digestion at room temperature (approx. $23 \pm 2{ }^{\circ} \mathrm{C}$ ) for $1 \mathrm{~h}$ and a second digestion for additional $1 \mathrm{~h}$ at $85 \pm 2{ }^{\circ} \mathrm{C}$ in a water bath, then $50 \mathrm{~mL}$ of ammonium acetate $1 \mathrm{~mol} \mathrm{~L}^{-1}$, was added and the extraction performed as step 1 , the solid residue was retained for aqua regia digestion.

Step 4 (residual fraction):

Residual material remaining after step 3 of the sequential extraction was digested in the same manner after quantitative transferring of the residual from PTFE vessel to the glass flask. The residue from the last step was digested with a mixture of $20 \mathrm{~mL}$ aqua regia as described above.

Using the computer program SURFER, the data were introduced to develop a map of iso-concentration for observe in general the situation of the sampling points with higher concentration of arsenic and lead in the study area.

\section{Results and discussion}

During the fieldwork, statistical data of environmental parameters were listed in Table 1, the observed.

\subsection{Granulometric study}

The results of the sieve study for the selected samples is summarized in Table 2, as seen the averages ranging between 154 microns and 379 microns, with an overall median of 266.94 microns and a standard deviation of 81.32 microns.

\subsection{Total concentration of arsenic and lead in soil samples}

For the determination of the total lead and arsenic concentrations in the digested samples the calibration curve was in the

Table 1. Statistical data of environmental parameters during the fieldwork

\begin{tabular}{lccccccc}
\hline & $\begin{array}{c}\text { Relative } \\
\text { humidity } \\
(\%)\end{array}$ & $\begin{array}{c}\text { Wind } \\
\text { speed } \\
(\mathrm{mph})\end{array}$ & $\begin{array}{c}\text { Electric } \\
\text { Conductivity } \\
(\mathrm{S} / \mathrm{cm})\end{array}$ & $\mathrm{pH}$ & $\begin{array}{c}\text { Environmental } \\
\text { temperature } \\
\left({ }^{\circ} \mathrm{C}\right)\end{array}$ & $\begin{array}{c}\text { Surface } \\
\text { temperature } \\
\left({ }^{\circ} \mathrm{C}\right)\end{array}$ & $\begin{array}{c}\text { Temperature at } \\
30 \mathrm{~cm} \text { depth } \\
\left({ }^{\circ} \mathrm{C}\right)\end{array}$ \\
\hline Minimum & 28.8 & 0.0 & 0.12 & 6.2 & 14.4 & 15 & 20.0 \\
Maximum & 66.2 & 9.4 & 0.81 & 7.9 & 38.1 & 54 & 34.0 \\
Median & 48.9 & 4.8 & 0.26 & 7.4 & 25.6 & 28.5 & 26.5 \\
SD & 11.4 & 2.6 & 0.16 & 0.6 & 5.4 & 13.1 & 4.1 \\
\hline
\end{tabular}

$\mathrm{SD}=$ Standard Deviation 
Table 2. Media and mode of the samples analyzed

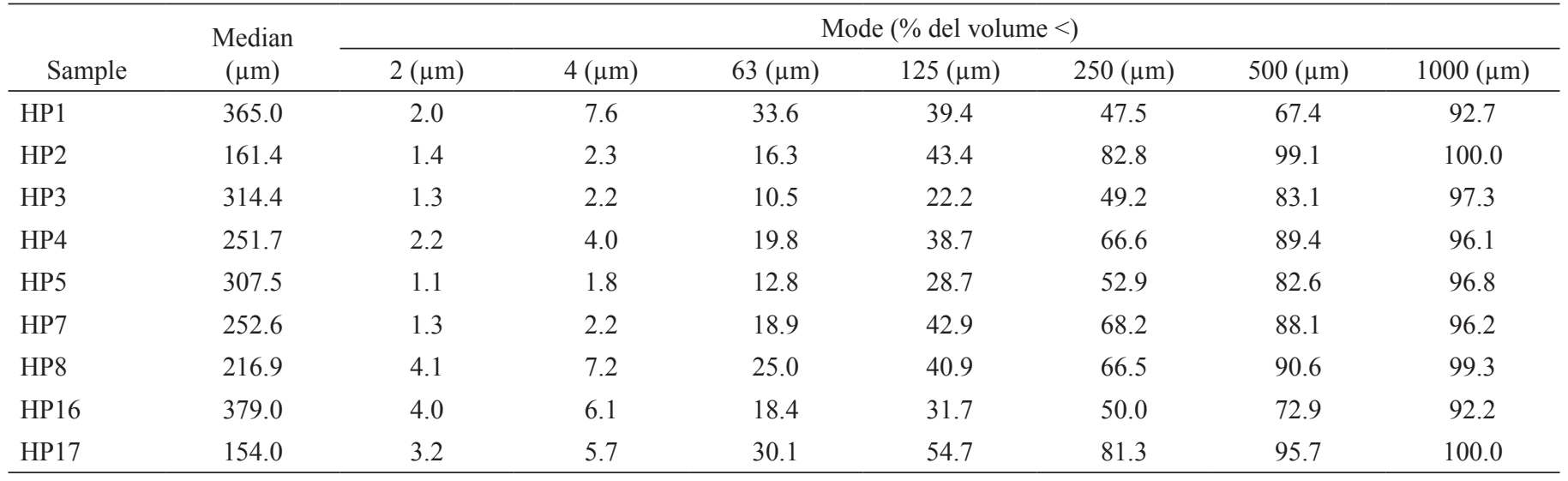

range aforementioned $(\mathrm{r}=0.997, \mathrm{n}=6$ for arsenic and $\mathrm{r}=0.998$, $\mathrm{n}=6$ for lead). The LOD was $0.01 \mathrm{mg} \mathrm{kg}^{-1}$ and $0.13 \mathrm{mg} \mathrm{kg}^{-1}$ and the LOQ was $0.03 \mathrm{mg} \mathrm{kg}^{-1}$ and $1.13 \mathrm{mg} \mathrm{kg}^{-1}$ respectively. The percentage of recovery showed no significant differences between the measured values for the total arsenic and lead content in the blank sample.

Total concentration of arsenic and lead $(\mathrm{mg} / \mathrm{kg}$ dry material) from the total digestion analysis is presented in Table 3.

In the case of arsenic concentrations ranged from $7.42 \pm$ 0.65 to $509.84 \pm 40.18 \mathrm{mg} \mathrm{kg}^{-1}, 8$ soil samples presented total

Table 3. Total concentration of $\mathrm{As}$ and $\mathrm{Pb}(\mathrm{mg} / \mathrm{kg}$ dry weight) in soil samples from Hidalgo del Parral, Chihuahua

\begin{tabular}{lll}
\hline $\begin{array}{l}\text { Sample } \\
(\boldsymbol{n}=\mathbf{3})\end{array}$ & \multicolumn{1}{c}{ As } & \multicolumn{1}{c}{$\mathrm{Pb}$} \\
\hline HP1 & $476.00 \pm 38.01$ & $5206.77 \pm 184.27$ \\
HP2 & $159.35 \pm 11.15$ & $4288.40 \pm 113.89$ \\
HP3 & $206.56 \pm 14.46$ & $5089.64 \pm 186.16$ \\
HP4 & $154.89 \pm 10.84$ & $3906.6 \pm 228.91$ \\
HP5 & $377.15 \pm 30.17$ & $4429.93 \pm 109.39$ \\
HP6 & $509.84 \pm 40.18$ & $4682.32 \pm 440.81$ \\
HP7 & $299.70 \pm 23.98$ & $5040.03 \pm 340.16$ \\
HP8 & $7.42 \pm 0.65$ & $711.94 \pm 11.54$ \\
HP9 & $36.76 \pm 2.94$ & $3852.79 \pm 213.66$ \\
HP10 & NA & NA \\
HP11 & $47.11 \pm 3.77$ & $263.58 \pm 19.99$ \\
HP12 & $506.89 \pm 35.48$ & $2725.89 \pm 153.90$ \\
HP13 & $389.38 \pm 27.26$ & $3501.32 \pm 223.57$ \\
HP14 & $5.49 \pm 0.43$ & 109.919 .16 \\
HP15 & $14.93 \pm 1.19$ & $307.78 \pm 27.56$ \\
HP16 & $15.87 \pm 1.26$ & $1194.13 \pm 59.70$ \\
HP17 & $485.64 \pm 33.99$ & $4774.30 \pm 94.75$ \\
HP18 & $490.10 \pm 34.3$ & $5748.24 \pm 263.63$ \\
HPB ${ }^{\mathrm{a}}$ & $10.44 \pm 0.83$ & $78.03 \pm 2.67$ \\
\hline
\end{tabular}

a The sampling point was removed due to difficult access to the study site.

b Background soil.
As concentrations higher than $260 \mathrm{mg} \mathrm{kg}^{-1}$, which has been used by Mexican guidelines as trigger level for industrial soil remediation [11]. In detail, $47 \%$ of soil samples presented arsenic concentrations between 299-510 $\mathrm{mg} \mathrm{kg}^{-1}$ (HP1, HP5- HP7, HP12, HP13, HP17, HP18) and the other 53\% of samples are below $207 \mathrm{mg} \mathrm{kg}^{-1}$ (HP2-HP4, HP8-HP11, HP14-16). The reported arsenic is originated by the mining activities, this is reflected because the concentration of the background soil which contains $10.44 \pm 0.83 \mathrm{mg} \mathrm{kg}^{-1}$ of arsenic. Figure 4 shows that the concentrations of As correspond to the samples taken in the northern part and the south part of the study area, this areas correspond to the mining tailings that are near to the residential zone.

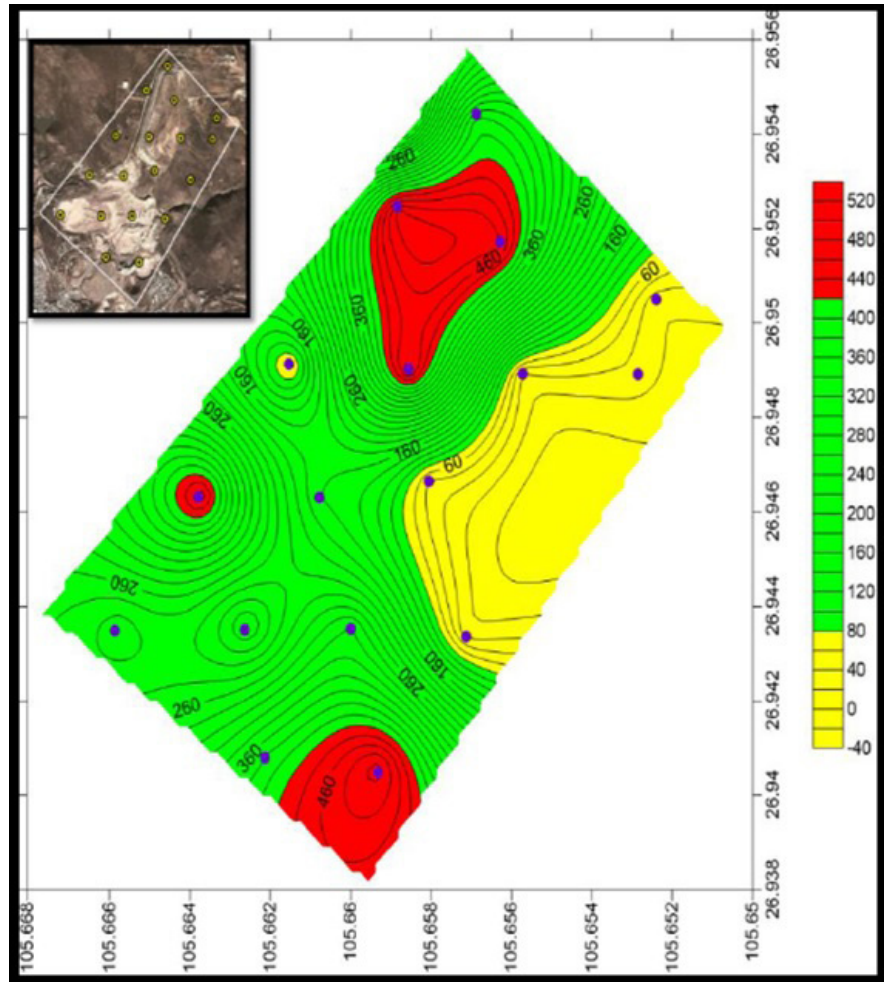

Figure 4. Overview of total arsenic concentrations of sampling points in the study area in $\mathrm{mg} / \mathrm{kg}$ (SURFER). 


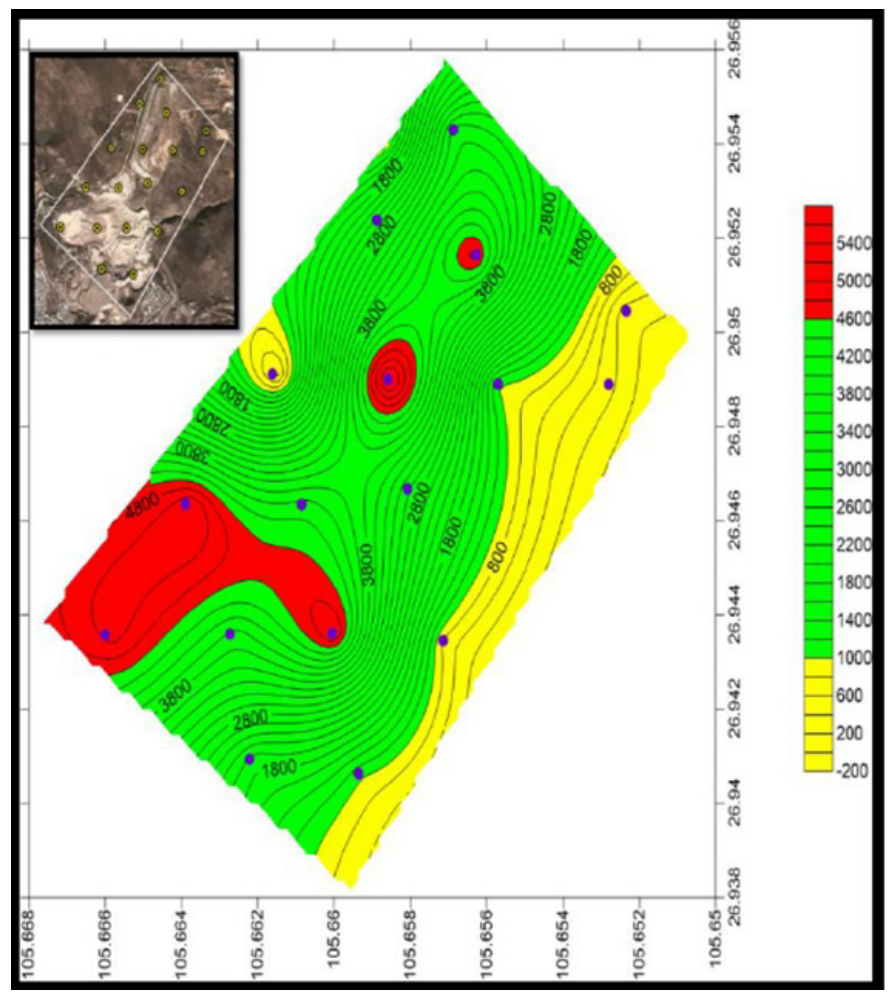

Figure 5. Overview of total lead concentrations of sampling points in the study area in $\mathrm{mg} / \mathrm{kg}$ (SURFER).

In the case of lead concentrations ranged from $78.03 \pm 2.67$ to $5748.24 \pm 263.63 \mathrm{mg} \mathrm{kg}^{-1}, 13$ soil samples presented total $\mathrm{Pb}$ concentrations higher than $800 \mathrm{mg} \mathrm{kg}^{-1}$, which has been used by Mexican guidelines as trigger level for industrial soil remediation [11]. In detail, $68 \%$ of soil samples presented lead concentrations between 1194-5748 $\mathrm{mg} \mathrm{kg}^{-1}$ (HP1, HP2, HP3, HP4, HP5, HP6, HP7, HP9, HP12, HP13, HP16, HP17, HP18) and the other $32 \%$ of samples are below $711 \mathrm{mg} \mathrm{kg}^{-1}$ (HP8, HP10, HP11, HP14, HP15). The reported lead is originated by the mining activities, this is reflected because the concentration of the background soil which contains $78.03 \pm 2.67 \mathrm{mg} \mathrm{kg}^{-1}$ of lead. Figure 5 shows that the concentrations of $\mathrm{Pb}$ correspond to the samples taken in all the study area, which is near to the residential zone.

It should be noted that the prevailing winds direction (from SO to NE) [18] in the area also pose a risk to the population, growing areas near the mine.

\subsection{Geochemical fraction of $\mathrm{As}$ and $\mathrm{Pb}$}

Heavy metal mobility and bioavailability in soils depend strongly on the mineralogical and chemical forms in which they occur. The results (Table 4) of this investigation have shown that for arsenic were highly associated with the oxidizable (F3) and residual fraction (FR), for arsenic. Almost $90 \%$ of the samples have most of the arsenic in the residual fraction (RF), these fraction is characterized by low mobility and low probabilities of posing adverse effects to the environment. It's observed that the content of arsenic in fraction 2 (F2) have less than $50 \mathrm{mg} \mathrm{kg}^{-1}$ of arsenic, although these values are minimal in a matter of accessibility, the content of arsenic in this zones is higher than the values established at international $(0.39 \mathrm{mg} / \mathrm{kg}$ for US residential areas, $12 \mathrm{mg} / \mathrm{kg}$ for Canada, $32 \mathrm{mg} / \mathrm{kg}$ for United Kingdom) and national guidelines $(22 \mathrm{mg} / \mathrm{kg}$ for residential/agricultural soil) $[11,19,20]$. That exposure to arsenic poses a carcinogenic hazard to the lung via both the oral and inhalation routes of exposure. The sites require more attention due to the possible risk to potentially exposed residents. As it can be observed in the Table 4, the samples have shown insignificant amounts associated with the extractable/exchangeable fraction (F1).

For lead (Table 5), distribution varies depending on the sample; it has no standard behavior as the case of arsenic. In detail 8 samples (HP1, HP2, HP5, HP6, HP9, HP13, HP17, HP18) contain more than $70 \%$ of lead in fraction $1(\mathrm{~F} 1)$ and fraction 2 (F2). The F1 involves weakly adsorbed metals retained on the solid surface by relatively weak electrostatic interaction; metals that can be released by ion-exchangeable processes. Metals on this fraction also can be replaced by neutral salts. The second fraction, bound to iron and manganese oxyhydroxides that are present in the soils can change their adsorption capacities drastically according to the redox conditions (presence/absence of $\mathrm{O}_{2}$ ), producing either $\mathrm{FeS}$ or $\mathrm{FeO}(\mathrm{OH})$

Table 4. Distribution of element fractionation for arsenic ( $\mathrm{mg} / \mathrm{kg}$ weight dry) in the study area of Hidalgo del Parral

\begin{tabular}{|c|c|c|c|c|c|c|c|}
\hline $\begin{array}{l}\text { Sample } \\
(n=2)\end{array}$ & $\begin{array}{l}\text { Step } 1 \\
\text { (F1) }\end{array}$ & $\begin{array}{c}\text { Step } 2 \\
\text { (F2) }\end{array}$ & $\begin{array}{c}\text { Step } 3 \\
\text { (F3) }\end{array}$ & $\begin{array}{c}\text { Residual } \\
\text { (RF) }\end{array}$ & $\begin{array}{l}\text { Total } \\
\text { SEP }\end{array}$ & $\begin{array}{c}\text { Total } \\
\text { Digestion }\end{array}$ & $\begin{array}{c}\text { Recovery } \\
(\%)^{\mathrm{a}}\end{array}$ \\
\hline HP1 & $11.63 \pm 0.58$ & $33.83 \pm 1.69$ & $100.45 \pm 5.02$ & $154.70 \pm 7.73$ & 300 & 476 & 63 \\
\hline HP6 & $6.26 \pm 0.31$ & $32.54 \pm 1.63$ & $26.22 \pm 1.31$ & $241.11 \pm 12.06$ & 306 & 509 & 60 \\
\hline HP7 & $4.16 \pm 0.21$ & $32.59 \pm 1.63$ & $114.17 \pm 5.71$ & $77.92 \pm 3.90$ & 228 & 299 & 76 \\
\hline HP17 & $1.84 \pm 0.09$ & $34.51 \pm 1.73$ & $36.14 \pm 1.81$ & $231.16 \pm 11.56$ & 303 & 485 & 63 \\
\hline HP18 & $3.15 \pm 0.10$ & $48.99 \pm 2.45$ & $78.13 \pm 3.91$ & $212.76 \pm 10.62$ & 343 & 490 & 70 \\
\hline
\end{tabular}

$\mathrm{a}=[(\mathrm{F} 1+\mathrm{F} 2+\mathrm{F} 3+\mathrm{TR}) /($ Total digestion $)] \times 100$ 
Table 5. Distribution of element fractionation for lead ( $\mathrm{mg} / \mathrm{kg}$ weight dry) in the study area of Hidalgo del Parral

\begin{tabular}{|c|c|c|c|c|c|c|c|}
\hline $\begin{array}{l}\text { Sample } \\
(n=2)\end{array}$ & $\begin{array}{l}\text { Step 1 } \\
\text { (F1) }\end{array}$ & $\begin{array}{c}\text { Step } 2 \\
\text { (F2) }\end{array}$ & $\begin{array}{c}\text { Step } 3 \\
\text { (F3) }\end{array}$ & $\begin{array}{c}\text { Residual } \\
\text { (RF) }\end{array}$ & $\begin{array}{l}\text { Total } \\
\text { SEP }\end{array}$ & $\begin{array}{c}\text { Total } \\
\text { Digestion }\end{array}$ & $\begin{array}{c}\text { Recovery } \\
(\%)^{\mathrm{a}}\end{array}$ \\
\hline HP1 & $1,840 \pm 92$ & $2,219 \pm 110$ & $647 \pm 32$ & $230 \pm 11$ & 4,937 & 5,206 & 95 \\
\hline HP3 & $529 \pm 26$ & $688 \pm 34$ & $2,507 \pm 125$ & $1,015 \pm 50$ & 4,741 & 5,089 & 93 \\
\hline HP4 & $492 \pm 24$ & $1,257 \pm 63$ & $1,589 \pm 79$ & $567 \pm 28$ & 3,905 & 3,906 & 99 \\
\hline HP7 & $1,064 \pm 53$ & $1,854 \pm 93$ & $647 \pm 32$ & $1,061 \pm 53$ & 4,627 & 5,040 & 92 \\
\hline HP9 & $1,425 \pm 71$ & $1,354 \pm 68$ & $270 \pm 13$ & $225 \pm 11$ & 3,275 & 3,852 & 85 \\
\hline HP12 & $1,130 \pm 56$ & $820 \pm 41$ & $723 \pm 36$ & $109 \pm 5$ & 2,783 & 2,725 & 102 \\
\hline HP13 & $1,547 \pm 77$ & $1,127 \pm 56$ & $280 \pm 14$ & $267 \pm 13$ & 3,223 & 3,501 & 92 \\
\hline
\end{tabular}

$\mathrm{a}=[(\mathrm{F} 1+\mathrm{F} 2+\mathrm{F} 3+\mathrm{TR}) /($ Total digestion $)] \times 100$

liberating co-precipitated or adsorbed metals at every change [21]. For the rest of the samples, lead is distributed in the second and third fraction (F2 and F3). Given the absence of organic matter in the case of F3, the extracts obtained during this step are metals bound to sulphides, being unstable only under severe oxidizing conditions [22], making it one of the most stable fractions. As it is observed, lead concentrations in the F1 are above the values established at international $(840 \mathrm{mg} / \mathrm{kg}$ for US residential areas, $750 \mathrm{mg} / \mathrm{kg}$ for European Union) and national guidelines (400 mg/kg for residential/agricultural soil) [11, 22].

For both elements the sum of concentrations for each fraction was compared with the total concentration from the values in Table 3. Reasonable percentages of recovery of all samples for arsenic were from 51 to $76 \%$. It is considered that solubility and equilibration limitations in extraction procedure are probably responsible for the lower extractability of arsenic [23]. In the case of lead [24] good recovery percentages are observed ranged from $85-112 \%$. Less stable forms of arsenic and lead compounds ranged between 1.84-48.99 and 3.29$2,538 \mathrm{mg} \mathrm{kg}^{-1}$ respectively, which indicated a potential risk.

\subsection{Risk estimation from exposure to bioaccessible fractions}

Regarding the doses of reference published in the Integrated Risk Information System [25] of the United States for As (3 x $10^{-4} \mathrm{mg} / \mathrm{kg}$-d for oral exposure), and considering an ingestion of $32 \mathrm{mg}$ soil/d [26], through a hand to mouth mechanism and considering a mean weight in Mexican male population of 77.7 $\mathrm{kg}$ [27], there is low potential risk to the population of Parral since the exposure is from 15 to 396 times smaller than the dose of reference. However, there is risk cancer through inhalation. Risk calculation could not be done for $\mathrm{Pb}$ since there is no dose of reference available. On the other hand, a mixed effect of As and $\mathrm{Pb}$ exposure might be assessed.

\subsection{Policy Making Proposal}

According to the Mexican Ministry of Environment [28], there are more than 635 potentially contaminated sites in Mexico. From those, just a little fraction has been remediated because of limited funding and limited capacity for characterizing and lack of a methodology to prioritize them. Even though there is a standard for contaminated soil since 2007 [11], there was not considered a clear assessment for stability of chemical species in soil matrixes. This situation is similar in other Latin American Countries and other regions where the lack of regulation has turned into large impacts of mining activities.

Chemical speciation methods can provide a set of criteria that might be used by local authorities to prioritize contaminated sites and focus efforts in those with higher risk to health or the environment. Fractions F1 and F2 are the ones that might be of concern while combined with high exposition through ingestion or respiration.

\section{Conclusions and recommendations}

An exploratory and systematic surface sampling was done in order to establish the presence of arsenic and lead in the mining area of Hidalgo del Parral, Chihuahua.

The arsenic and lead quantification method was validated using Atomic Absorption Flame \& Hydride-Generation Spectrometry with appropriate performance and finding concentration ranges of $7.42 \pm 0.65$ to $509.84 \pm 40.18\left[\mathrm{mg} \mathrm{kg}^{-1}\right]$ for arsenic \& $83.34 \pm 2.67$ to $5579 \pm\left[\mathrm{mg} \mathrm{kg}^{-1}\right]$ for lead. 
From a total of 18 samples taken at the site, eight samples $(47 \%)$ had higher concentration of arsenic them the limit established in NOM-147-SEMARNAT/SSA1-2004, which corresponds to $260 \mathrm{mg} \mathrm{kg}^{-1}$; on the other hand, 13 samples $(76 \%)$ had higher concentration of lead than the limit of $800 \mathrm{mg} \mathrm{kg}^{-1}$ established in the same regulation. The samples out of range for both metals were taken to a speciation test consisting in sequential extractions using the method BCR (Community Bureau of Reference) to determine their bioavailability.

In case of arsenic, the speciation shows that the higher fraction is in the oxidized fraction (F3) and in the residual fraction (FR), which suggest that the mobility \& bioavailability of this element is very low as well as the migration to other compartments; therefore, environmental \& health effects are not evident. However, even though the arsenic concentration in the reducible fraction (F2) is lower than $50 \mathrm{mg} \mathrm{kg}^{-1}$, the proximity to populated areas increases the chronic exposition risk from ingestion/respiration of dusts in these sites.

In case of lead, eight samples had the higher concentration in the fraction F1 and fraction F2, suggesting that the little stability of the metal is high since the chemical species have weak adherence to the soil matrix and can be released by ionic exchange processes; these samples had concentration values higher than the limit of the soil standard and represent a risk to health and the environment.

For both elements, recovery percentage of the speciation method was evaluated comparing the results with the total concentration of the samples, showing values of $85 \%$ to $112 \%$.

Regarding the risk quantification for arsenic exposure, dose of reference was not reached by two orders of magnitude. However, there is risk of a mixed effect of $\mathrm{Pb}$ and As chronic exposure.

A bioaccesibility study for both metals as well as a fine particle $\left(\mathrm{PM}_{2.5}\right)$ in air are recommended in order to assess urban contamination and the risk to health by accidental ingestion of metal-polluted soils.

As Policy Making action, risk assessment should be included in environmental regulation using the estimation of chemical speciation of species of concern (those that are more easy to move in the environment and that can be absorbed by the organism).

\section{Acknowledgements}

We wish to thank Dra. Pura Alonso Abella, from Escuela Politécnica Superior de Ingeniería de Manresa, España. We also thank to the authorities of Mina La Prieta of Parral Chihuahua for allowing the access to the studied sites, as well as to Dr. Rene Rosiles Martínez from Facultad de Medicina Veterinaria y Zootecnia, UNAM.

\section{References}

1. INE. http://www2.ine.gob.mx/publicaciones/libros/16/parte3_12. html, 2007, Accesed in June, 2016.
2. West, R. C. La Comunidad Minera en el Norte de la Nueva España: El Distrito Minero de Parral. Introducción y Notas: Zacarías Márquez, Z. T.; Traductor: Cabrera, F. R. Chihuahua, Gobierno del Estado. Secretaria de Educación y Cultura. Biblioteca Chihuahuense, 2002, 195.

3. Rodríguez, V.L.; Ferman, Á.H.; Torres, C.E.; Sáenz, M.L.; Luna, C.J.; Herrera, E.; González, G.; Aranda, C.D.; Carrillo, J.; Lozoya, L. J. Environ. Sci. Eng. 2010, 4, 12-17.

4. INEGI. Municipal Geographic Information of the United States of Mexico, Hidalgo del Parral, Chihuahua, Geostatistics. 2009 key 08032.

5. LAFQA. Diagnóstico ambiental de las presas inactivas de jales y zonas de influencia, Santa Bárbara, Chihuahua: México D.F., Reporte elaborado para Minerales Metálicos del Norte S.A. 2005, 180.

6. Reyes, A.; Ramos, S.; Avelar, F.; Godínez, L.; Rodríguez, F. Conciencia Tecnológica. 2008, 35, 32-35.

7. Aditi, R.; Katarzyna, K.; López, P.; Rosado, L. J.; Cebrian, E.M.; García, V. G.; Ronquillo, D.; Stoltzfus, J. J. Environ. Res. 2011, 111, 670-676.

8. Rodríguez, L. M.; Torres E.; Sáenz, L.; Avitia, M.; Rodríguez, G.; Herrera, E.; Navarro, C. J.; González, G.; Lozoya, L.; Acosta, D. Journal of Environmental Science and Engineering. 2012, A1, 286-294.

9. Quintana, M.E.C.; Sosa, C.M.; Rubio, A.H.; Puga, T.S.; Quintana, M.G.; Moreno, M.; Alcalá, J.J. Revista Latinoamericana de Recursos Naturales. 2008, 4, 68-76.

10. Rauret, G.; López-Sánchez, J. F.; Sahuquillo, A.; Rubio, R.; Davidson, C.; Quevauviller, P. J. Environ. Monit. 1999, 1, 57-61.

11. SEMARNAT. NOM-147-SEMARNAT/SSA1-2004, Diario Oficial de la Federación. 2007.

12. Secretaría de Economía, NMX-AA-132-SCFI-2006, Diario Oficial de la Federación. 2006.

13. García, C. Estudio del mecanismo de generación de drenajes ácidos en una presa de estériles piríticos. Tesis de Doctorado, Universidad Complutense de Madrid, Facultad de Ciencias Químicas, Departamento de Ciencia de los Materiales e Ingeniería Metalúrgica, ISBN: 84-669-2400-0, 1998, 114-116.

14. USEPA. https://www.epa.gov/sites/production/files/2015-06/documents/epa-3050b.pdf. 1996. Accessed in June, 2015.

15. USEPA. https://www.epa.gov/sites/production/files/2015-12/documents/7062.pdf. 1994. Accessed in June, 2015.

16. USEPA. https://www.epa.gov/sites/production/files/2015-12/documents/7000b.pdf. 1996. Accessed in June, 2015.

17. Fathollahzadeh, H.; Kaczala, F.; Bhatnagar, A.; Hogland, W. Environ Sci. Pollut. Res. 2014, 21, 2455-2464.

18. INAFED. http://www.inafed.gob.mx/work/enciclopedia/EMM08 chihuahua/municipios/08032a.html. 1999. Accessed in June, 2016.

19. Teaf, C. M.; Covert, D. J.; Teaf, P. A.; Page, E.; Starks, M. J. http:// scholarworks.umass.edu/soilsproceedings/vol15/iss1/10. 2010. Accessed in June, 2015.

20. UKEPA. https://www.gov.uk/government/uploads/system/uploads/attachment_data/file/313869/scho0409bpvy-e-e.pdf. 2009. Accessed in June, 2016.

21. Cornelis, R.; Crews, H.; Caruso, J.; Heumann, K. Handbook of Elemental Speciation: Techniques and Methodology, John Wiley \& Sons, Ltd. 2003. ISBN: 0-471-49214-0.

22. González, F.; Tornero, C. M.; Ángeles, C.; Bonilla, N. Rev. Int. Contam. Ambient. 2009, 25, 15-22.

23. Shiowatana, J.; McLaren, R. G.; Chanmekha, N. J. Environ. Qual. 2001, 30, 1940-1949. 
24. Hlavay, J.; Prohaska, T.; Weisz, M.; Wenzel, W. W.; \& Stingeder, G. J. Pure and Applied chemistry 2004. 76, 415-442.

25. IRIS. https://www.epa.gov/iris. 2015. Accessed in June, 2016.

26. Irvine, G.; Doyle, J. R.; White, P. A.; Blais, J. M. Science of the Total Environment, 2014, 470, 138-146.
27. Osuna-Ramírez, I.; Hernández-Prado, B.; Campuzano, J. C.; Salmerón, J. Salud pública de México, 2006, 48, 94-103.

28. SEMARNAT. Http://apps1.semarnat.gob.mx/dgeia/informe_2008 /07_residuos/cap7_6.html. 2016. Accessed in June, 2016. 


\title{
General Method for Selective Mono-Boc Protection of Diamines and Thereof
}

\author{
Felipe Antonio Servín, ${ }^{1}$ José Alfonso Romero, ${ }_{1}^{1}$ Gerardo Aguirre, ${ }^{1}$ Douglas Grotjahn, ${ }^{2}$ \\ Ratnasamy Somanathan, ${ }^{1}$ and Daniel Chávez*1 \\ 1 Centro de Graduados e Investigación en Química del Instituto Tecnológico de Tijuana, Apartado Postal 1166, \\ Tijuana, B.C. 22510 México. \\ 2 Department of Chemistry and Biochemistry, San Diego State University, San Diego, CA 92182-1030, United States. \\ * Author to whom correspondence should be addressed.E-mail: dchavez@tectijuana.mx \\ Phone and fax: 52 (664) 623-3772 and 52 (664) 623-4043.
}

Received October 10 ${ }^{\text {th }}, 2016$; Accepted December 15 ${ }^{\text {th }}, 2016$.

\begin{abstract}
Here we report a simple and efficient protocol for selectively diamine protection with Boc using $\mathrm{Me}_{3} \mathrm{SiCl}$ or $\mathrm{SOCl}_{2}$ as $\mathrm{HCl}$ source in "one-pot" procedure. This methodology is extended to 1,2- to 1,8-diamines to obtain the corresponding mono-Boc protected diamines.

Keywords: Chiral, cyclohexane-1,2-diamine, 1,2-diphenylethane1,2-diamine, Boc monoprotection, diamines
\end{abstract}

\section{Introduction}

Monoprotection of symmetrical or unsymmetrical diamines is an ongoing challenge to organic chemists. Many of these monoprotected chiral 1,2-diamines have been used in organocatalysts and ligand-metal catalysts for many asymmetric transformations, such as asymmetric transfer hydrogenation. Aldol reaction, Michael, reaction silylcyanation, and Strecker reaction [1-7]. From these diamines, non-racemic trans-cyclohexane-1,2-diamine (1) is readily available in both enantiomeric forms, by simple resolution of the commercial crude racemate with tartaric acid [8]. Several methods for monoprotection of diamine (1) have been reported in the literature (Fig. 1) [9]. Some of these methods report excellent yields of the monoprotected diamine; yet, others in our hands led to mono- and di-protected product formation needing extensive chromatographic separation.
Resumen. Se describe un método simple y eficiente usando $\mathrm{Me}_{3} \mathrm{SiCl}$ o $\mathrm{SOCl}_{2}$ como fuente de $\mathrm{HCl}$ para la monoprotección con Boc de diaminas, esta monoprotección se realiza mediante una reacción directa en un solo reactor. El método desarrollado se utilizó también en la monoprotección con Boc de aminas alifáticas (1,2- a 1,8-diaminas). Palabras clave: Quiral, 1,2-ciclohexandiamina, 1,2-difenil-1,2-etandiamina, monoprotección con Boc, diaminas.

\section{Results and discussion}

A recent report highlighted the use of acetyl chloride to monoprotect cyclohexane-1,2-diamine at $0{ }^{\circ} \mathrm{C}$, whereas in our hands the main product obtained was the diprotected cyclohexane-1,2-diamine [9b]. However, the reaction of the diamine with various arylsulfonyl chlorides give mainly to the monoprotected sulfonylamide. Recently we employed a wide variety of these enantioenriched monosulfonamides in the asymmetric transfer hydrogenation (ATH) of aromatic ketones (1a) [10].

All of these ligands were readily synthesized by reacting $(1 R, 2 R)$-cyclohexane-1,2-diamine tartrate salt with arylsulfonyl chloride in $\mathrm{DCM} / \mathrm{NEt}_{3}$ at $0{ }^{\circ} \mathrm{C}$. The monosulfonamides were obtained in $\sim 40 \%$ yields using 5 fold excess of the diamine, with little diprotected amine formation, which can be purified by acid workup [11]. Literature also reveal that sulfonamides with electron withdrawing groups, such as nitro can be

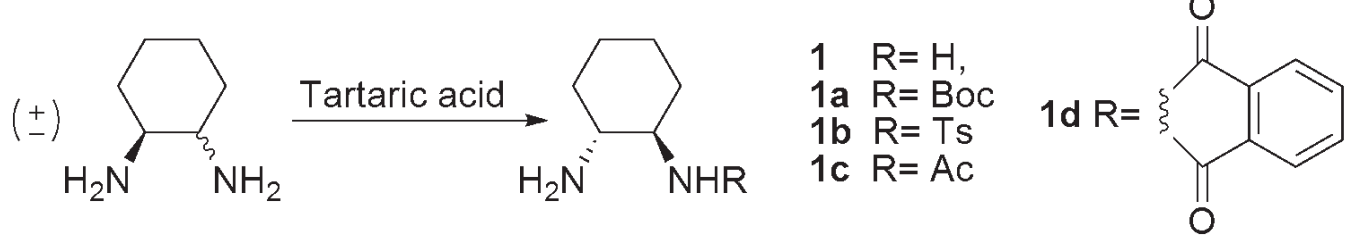

Figure 1. Monoprotected trans-cyclohexane-1,2-diamine. 
Felipe Antonio Servín et al.

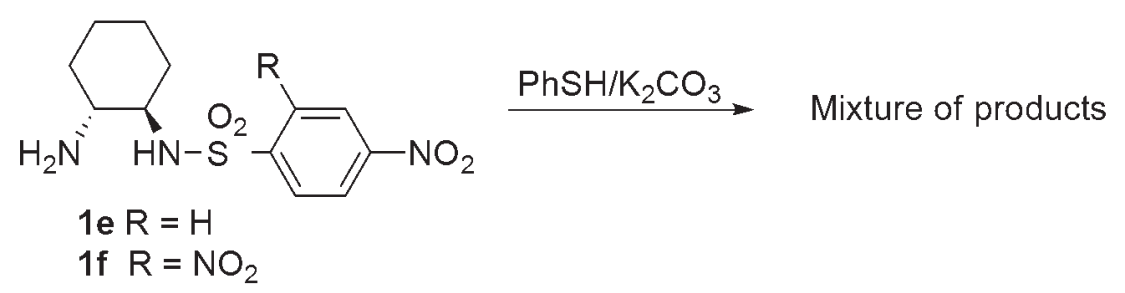

Figure 2. Deprotection of nitrosulfonamides $\mathbf{1 e}$ and $\mathbf{1 f}$.

deprotected using PhSH $/ \mathrm{K}_{2} \mathrm{CO}_{3}$ in DMF. Since these monosulfonamides can be prepared easily, we explored the deprotection of $p-\mathrm{NO}_{2}(\mathbf{1 e})$ and 2,4-dinitro (1f) arylsulfonamides using the above mentioned methods. Unfortunately, all attempts led to a mixture of products (Fig. 2).

Looking for an efficient and simple method for diamine monoprotection, we found the procedure developed by $\mathrm{Ha}$ and co-workers, involving the monoprotonation of the diamine $\mathbf{1}$ using 1 equivalent of $\mathrm{HCl}$, followed by treatment with Boc all in one pot, led to $80 \%$ of mono-Boc protection of diamine (1a) [12]. Similary mono hydrochlorination was also reported by Nguyen in the synthesis of mono-diamine Schiff bases [13]. Li and coworkers reported preparation of mono-Boc protected mixed primary-secondary amines starting with a bromoalkylamine hydrobromide and $\mathrm{Boc}_{2} \mathrm{O} / \mathrm{Et}_{3} \mathrm{~N}$ in $\mathrm{MeOH}$ with good yields [14]. There are many literature citations to make mono-Boc protected cyclohexane-1,2-diamine using the mono-hydrochlorination method [13], the only drawback of this reaction is the use of compressed anhydrous $\mathrm{HCl}$ gas. An alternative $\mathrm{HCl}$ source is the in situ generation of $\mathrm{HCl}$ from chlorotrimethylsilane $\left((\mathrm{Me})_{3} \mathrm{SiCl}\right)$ or thionyl chloride $\left(\mathrm{SOCl}_{2}\right)$ with anhydrous methanol. Chlorotrimethylsilane, a liquid with a boiling point of $57{ }^{\circ} \mathrm{C}$ can be purchased in $>99 \%$ purity and redistilled before use [15], and can be weighed accurately to generate the required amount of $\mathrm{HCl}$ gas with anhydrous methanol.

The methodology proposed (Fig. 3) consisted in treating $(1 R, 2 R)$-cyclohexane-1,2-diamine tartrate salt with $4 \mathrm{~N} \mathrm{NaOH}$, to give the diamine (1) as a free base. Then methanol anhydrous at $0{ }^{\circ} \mathrm{C}$ is added, followed by dropwise addition of 1 eq of $\mathrm{Me}_{3} \mathrm{SiCl}$. The mixture is allowed to come to RT and $1 \mathrm{~mL}$ of water is added, followed by $\mathrm{Boc}_{2} \mathrm{O}$ in $\mathrm{MeOH}$. The mixture is stirred at RT for $1 \mathrm{hr}$, diluted with water, washed with ethylic ether, $\mathrm{pH}$ adjusted to $>12$ with $\mathrm{NaOH}$ and then extracted into dichloromethane to give a pure monoprotected cyclohexane-1,2-diamine (1a) in $66 \%$ yield (Table 1). We were able to scale up the methodology to $\sim 4.0 \mathrm{~g}$.

The monoprotection was also carried out with $\mathrm{SOCl}_{2}$ as the $\mathrm{HCl}$ source using the same work-up procedure as above, but the final product was obtained in lower yield (41\%).

This methodology was also used with $1 R, 2 R$-1,2-diphenylethyl-1,2-diamine (2) and seven aliphatic diamines (3-9). Following the same procedure as obtaining $\mathbf{1 a}$, we were able to obtain the mono-Boc protected diamines 2a-9a (Fig. 4) in moderate yields (Table 1). For the racemic tert-butyl (2-aminopropyl) carbamate (3a), the monoprotection goes to the amine at C-1, suggesting that 1 eq of $\mathrm{Me}_{3} \mathrm{SiCl}$ as $\mathrm{HCl}$ source, prefers to protonate amine $\mathrm{C}-2$, that is more basic than the amine at $\mathrm{C}-1$, leaving the monoprotection at $\mathrm{C}-1$. This was established by analysis of NMR HMBC experiment were the protons of the methylene $\left(\delta_{\mathrm{H}} 3.15\right.$ and $\left.2.90 \mathrm{ppm}\right)$ correlate with the carbamate carbonyl $\left(\delta_{\mathrm{C}} 156.3 \mathrm{ppm}\right)$, confirming the monoprotection on the $\mathrm{C}-1$ amine. Purity was determined by GC-MS and all monoprotected diamines 1a-9a were obtained from 93 up to $>99 \%$ pure (Table 1). Spectroscopic data were in good agreement with those reported in the literature [9d, 13c, 16-20].

In conclusion, we have reported an efficient and a simple "one-pot" reaction for obtaining mono-Boc protected diamines (1a-9a) using $\mathrm{Me}_{3} \mathrm{SiCl}$ to generate the mono $\mathrm{HCl}$ salt of the diamines. This method can be extended to other diamines.

\section{General Experimental Procedures}

Melting points were obtained on an Electrothermal 88629 apparatus and are uncorrected. Infrared spectra (IR) were recorded
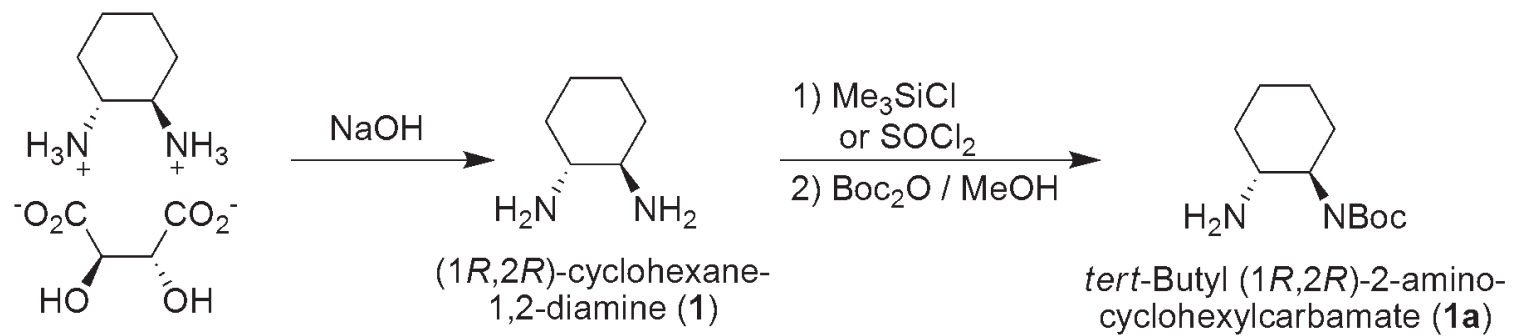

Figure 3. Methodology for mono-Boc protection of chiral cyclohexane-1,2-diamine (1a). 


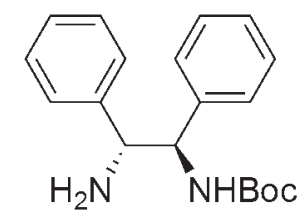

$2 \mathbf{a}$

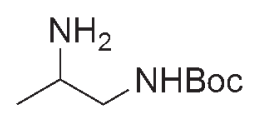

$3 a$
$\mathrm{H}_{2} \mathrm{~N} \overbrace{4 a}^{\mathrm{NHBOC}}$<smiles>CC(C)(C)OC(=O)NCCCCCCNCCCCN</smiles><smiles>NCCCCCCCNC(=O)O</smiles><smiles>NCCCCCCCCNC(=O)O</smiles>

Figure 4. Mono-Boc protected diamines 2a-9a.

Table 1. Yields and purities on mono-Boc protection of diamines (1a-9a).

\begin{tabular}{ccc}
\hline $\begin{array}{c}\text { Monoprotected } \\
\text { diamine }\end{array}$ & Yield (\%) & \% Purity \\
\hline $1 \mathrm{a}$ & 66 & $>99$ \\
$2 \mathrm{a}$ & 45 & 93 \\
$3 \mathrm{a}$ & 72 & 98 \\
$4 \mathrm{a}$ & 22 & 96 \\
$5 \mathrm{a}$ & 24 & $>99$ \\
$6 \mathrm{a}$ & 19 & 99 \\
$7 \mathrm{a}$ & 42 & 99 \\
$8 \mathrm{a}$ & 46 & $>99$ \\
$9 \mathrm{a}$ & 42 & $>99$ \\
\hline
\end{tabular}

${ }^{\text {a }}$ Determined by MS-GC

on a Perkin Elmer FT-IR 1600 spectrophotometer. NMR spectra were recorded on a Bruker Avance III spectrometer $400 \mathrm{MHz}$, in $\mathrm{CDCl}_{3}$ with TMS as internal standard. Mass spectra were obtained on an Agilent Technologies 5975C MS Spectrometer at $70 \mathrm{eV}$ by direct insertion.

\section{General procedure of mono-Boc protected of diamines 1a-9a}

Each diamine 1-9 ( 1 eq $\approx 1$ gr) was added anhydrous methanol at $0{ }^{\circ} \mathrm{C}$ under stirring, followed by the dropwise addition of freshly distilled $\mathrm{Me}_{3} \mathrm{SiCl}$ (1 eq). A white precipitate appeared at the bottom of the flask, the mixture was allowed to come to RT and water $(1 \mathrm{~mL})$ followed by $\mathrm{Boc}_{2} \mathrm{O}(1 \mathrm{eq})$ in $\mathrm{MeOH}$ (3 mL) was added. The mixture was stirred at RT for $1 \mathrm{hr}$, diluted with water $(50 \mathrm{~mL})$ and the aqueous layer washed with ether $(2 \times 75 \mathrm{~mL})$. The aqueous layer was adjusted to $\mathrm{pH}>12$ with $2 \mathrm{~N} \mathrm{NaOH}$ and extracted into dichloromethane $(3 \times 50 \mathrm{~mL})$. The combined organic layers were dried over anhydrous $\mathrm{Na}-$ ${ }_{2} \mathrm{SO}_{4}$ and solvent removal gave the corresponding monoprotected diamines 1a-9a.

tert-Butyl $(1 R, 2 R)$-2-aminocyclohexylcarbamate (1a) as a white solid $1.97 \mathrm{~g}, 66 \%$ yield. $[\alpha]^{20}{ }_{\mathrm{D}}=-44^{\circ}$ (c $3.0 \mathrm{mg} / \mathrm{mL}$, $\mathrm{MeOH})$. M.p. $105-107^{\circ} \mathrm{C}$; IR: 3351, 2909, 2888, 1882, 1518 , 1239, 1166, 1015, $983 \mathrm{~cm}^{-1} .{ }^{1} \mathrm{H} \mathrm{NMR}\left(400 \mathrm{MHz}, \mathrm{CDCl}_{3}\right): \delta$ 4.49 (brs, NH), 3.13 (brd, $J=6.2 \mathrm{~Hz}, 1 \mathrm{H}), 2.33$ (ddd, $J=10.4$, 3.8, $3.8 \mathrm{~Hz}, 1 \mathrm{H}), 1.98(\mathrm{~m}, 2 \mathrm{H}), 1.70(\mathrm{~m}, 2 \mathrm{H}), 1.45(\mathrm{~s}, 9 \mathrm{H}), 1.28$ $(\mathrm{m}, 2 \mathrm{H}), 1.12(\mathrm{~m}, 2 \mathrm{H}) .{ }^{13} \mathrm{C} \mathrm{NMR}\left(100 \mathrm{MHz}, \mathrm{CDCl}_{3}\right): \delta 156.1$, 79.4, 57.6, 55.7, 35.2, 32.9, 28.4, 25.2, 25.1. EIMS $m / z$ : $[\mathrm{M}]^{+}$ 214 N.D., 157 (1), 141 (13), 114 (8), 97 (100), 70 (15), 56 (47). Spectroscopic data were in good agreement with those reported in the literature [9d, 13c, 16].

The monoprotection for 1 , was also carried out with $\mathrm{SOCl}_{2}$ $(6.7 \mathrm{mmol})$ as the $\mathrm{HCl}$ source (caution! reacts vigorously with methanol). The addition was carried out at $-20^{\circ} \mathrm{C}$. Using the same work-up procedure as above, the final product tert-Butyl $(1 R, 2 R)$-2-aminocyclohexylcarbomate (1a) was obtained in $1.24 \mathrm{~g}, 41 \%$.

tert-Butyl ((1R,2R)-2-amino-1,2-diphenylethyl)carbamate (2a) White solid (665 mg, 45\%); ${ }^{1} \mathrm{H}$ NMR (400 $\mathrm{MHz}, \mathrm{CDCl}_{3}$ ): $\delta$ 7.32-7.24 (m, 10H), 5.78 (brs, NH), 4.85 (brs, $\mathrm{NH}_{2}$ ), 4.33 (d, $J$ $=4.2 \mathrm{~Hz}, 1 \mathrm{H}), 4.09(\mathrm{~s}, 1 \mathrm{H}), 1.32(\mathrm{~s}, 9 \mathrm{H}) .{ }^{13} \mathrm{C} \mathrm{RMN}(100 \mathrm{MHz}$, $\left.\mathrm{CDCl}_{3}\right): \delta 155.7,143.4,142.3,128.5,128.3,128.2,127.4$, 127.2, 127.0, 126.9, 126.8, 126.5, 79.3, 61.9, 60.0, 28.3. EIMS m/z: [M] 312 N.D., 238 (2), 222 (3), 196 (2), 150 (7), 106 (100). Spectroscopic data were in good agreement with those reported in the literature [17]. 
tert-Butyl (2-aminopropyl)carbamate (3a) White solid (1.7 g, $72 \%$ ), M.p. $68-70{ }^{\circ} \mathrm{C} ;{ }^{1} \mathrm{H}$ NMR $\left(400 \mathrm{MHz}, \mathrm{CDCl}_{3}\right): \delta 7.69$ (brs, $\mathrm{NH}), 5.07$ (brs, $\left.\mathrm{NH}_{2}\right), 3.14$ (brs, $\left.1 \mathrm{H}\right), 3.02(\mathrm{~m}, 1 \mathrm{H}), 2.90(\mathrm{~m}$, 1H), 1.45 (s, 9H), 1.08 (d, $J=6.4 \mathrm{~Hz}, 3 \mathrm{H}) .{ }^{13} \mathrm{C}$ NMR (100 $\mathrm{MHz}, \mathrm{CDCl}_{3}$ ): $\delta 156.4,79.2,47.8,47.1,28.4$, 20.1. EIMS $\mathrm{m} / \mathrm{z}$ : $[\mathrm{M}]^{+} 174$ N.D., 101 (24), 75 (11), 57 (100), 44 (100). Spectroscopic data were in good agreement with those reported in the literature [18].

tert-Butyl (2-aminoethyl)carbamate (4a) White solid (587 mg, $22 \%$ ), M.p. $64-66{ }^{\circ} \mathrm{C} ;{ }^{1} \mathrm{H}$ NMR (400 MHz, $\mathrm{CDCl}_{3}$ ): $\delta 5.55$ (brs, $\mathrm{NH}), 4.54$ (brs, $\left.\mathrm{NH}_{2}\right), 3.24(\mathrm{~d}, J=5.2,2 \mathrm{H}), 3.15$ (brs, $\left.1 \mathrm{H}\right), 2.86$ (brs, $1 \mathrm{H}), 1.44(\mathrm{~s}, 9 \mathrm{H}) \cdot{ }^{13} \mathrm{C}$ NMR $\left(100 \mathrm{MHz}, \mathrm{CDCl}_{3}\right): \delta 156.3$, 79.3, 41.8, 41.1, 28.4. EIMS m/z: [M] ${ }^{+} 160$ N.D., 118 (7), 103 (5), 87 (52), 75 (44), 57 (100), 43 (49). Spectroscopic data were in good agreement with those reported in the literature [18].

tert-Butyl (3-aminopropyl)carbamate (5a) White solid (565 mg, 24\%), M.p. $64-66{ }^{\circ} \mathrm{C} ;{ }^{1} \mathrm{H}$ NMR (400 MHz, $\mathrm{CDCl}_{3}$ ): $\delta 5.33$ (brs, NH), 4.95 (brs, $\mathrm{NH}_{2}$ ), 3.21 (d, $\left.J=5.6 \mathrm{~Hz}, 1 \mathrm{H}\right), 3.11$ (brs, $1 \mathrm{H}$ ), 2.82 (t, $J=6.4 \mathrm{~Hz}, 2 \mathrm{H}$ ), 1.70 (quint, $J=6.6, \mathrm{~Hz}, 2 \mathrm{H}$ ), 1.43 (s, 9H). ${ }^{13} \mathrm{C}$ NMR $\left(100 \mathrm{MHz}, \mathrm{CDCl}_{3}\right): \delta 156.3,79.1,38.4,37.9$, 31.3, 28.5. EIMS $m / z$ : [M] 174 (1), 118 (51), 101 (64), 74 (20), 57 (100). Spectroscopic data were in good agreement with those reported in the literature [18].

tert-Butyl (4-aminobutyl)carbamate (6a) White solid (406 mg, $19 \%$ ), M.p. $64-66{ }^{\circ} \mathrm{C} ;{ }^{1} \mathrm{H}$ NMR ( $400 \mathrm{MHz}, \mathrm{CDCl}_{3}$ ): $\delta 4.89$ (brs, $\mathrm{NH}), 3.11$ (brs, 4H, $\mathrm{CH}_{2}, \mathrm{NH}_{2}$ ), $2.75(\mathrm{t}, J=6.4 \mathrm{~Hz}, 2 \mathrm{H}), 1.52$ (m, 4H), 1.44 (s, 9H). ${ }^{13} \mathrm{C}$ NMR (100 MHz, $\left.\mathrm{CDCl}_{3}\right): \delta 156.1$, 79.1, 41.3, 40.3, 29.8, 28.5, 27.4. EIMS m/z: [M]+ 188 (1), 132 (52), 115 (47), 103 (30), 80 (9), 70 (84), 57 (100). Spectroscopic data were in good agreement with those reported in the literature $[18,19]$.

tert-Butyl (6-aminohexyl)carbamate (7a) White solid (781 mg, $42 \%$ ), M.p. $67-69^{\circ} \mathrm{C} ;{ }^{1} \mathrm{H}$ NMR (400 MHz, $\mathrm{CDCl}_{3}$ ): $\delta 4.60$ (brs, $\mathrm{NH}), 3.03$ (q, $J=6.0 \mathrm{~Hz}, 4 \mathrm{H}), 2.62(\mathrm{t}, J=7.2,6.4 \mathrm{~Hz}, 2 \mathrm{H}), 2.47$ (brs, $\mathrm{NH}_{2}$ ), 1.37 (brs, $\left.4 \mathrm{H}\right), 1.36$ (brs, $\left.13 \mathrm{H}\right), 1.26(\mathrm{~m}, 4 \mathrm{H}) .{ }^{13} \mathrm{C}$ NMR $\left(100 \mathrm{MHz}, \mathrm{CDCl}_{3}\right): \delta 156.0,79.0,41.7,40.5,32.9,30.0$, 28.5, 26.6, 26.5. EIMS $m / z$ : [M] 216 (2), 159 (19), 143 (59), 131 (37), 98 (46), 86 (71), 57 (100). Spectroscopic data were in good agreement with those reported in the literature [18].

tert-Butyl (7-aminoheptyl)carbamate (8a) White solid (814 mg, $46 \%$ ), M.p. $39-41{ }^{\circ} \mathrm{C} ;{ }^{1} \mathrm{H}$ NMR ( $400 \mathrm{MHz}, \mathrm{CDCl}_{3}$ ): $\delta 4.50$ (brs, $\mathrm{NH}), 3.02(\mathrm{q}, J=6.4 \mathrm{~Hz}, 2 \mathrm{H}), 2.61(\mathrm{t}, J=7.0 \mathrm{~Hz}, 2 \mathrm{H}), 1.56$ (brs, $\mathrm{NH}_{2}$ ), 1.37 (brs, $\left.13 \mathrm{H}\right), 1.24$ (brs, $\left.6 \mathrm{H}\right) .{ }^{13} \mathrm{C}$ NMR (100 $\mathrm{MHz}, \mathrm{CDCl}_{3}$ ): $\delta 155.0,78.0,41.1,39.6,32.5,29.0,28.1,27.4$, 25.8, 25.7. EIMS $m / z$ : [M] 230 (2), 173 (23), 157 (51), 145 (31), 112 (28), 100 (54), 57 (100). Spectroscopic data were in good agreement with those reported in the literature [19, 20].

tert-Butyl (8-aminooctyl)carbamate (9a) White solid (711 mg, 42\%). ${ }^{1} \mathrm{H}$ NMR (400 MHz, $\mathrm{CDCl}_{3}$ ): $\delta 4.51$ (brs, $\left.\mathrm{NH}\right), 3.03$ (q, $J=6.3,6.0 \mathrm{~Hz}, 2 \mathrm{H}), 2.62$ (t, $J=7.0 \mathrm{~Hz}, 2 \mathrm{H}), 2.22$ (brs, $\mathrm{NH}_{2}$ ),
1.37 (brs, $13 \mathrm{H}), 1.23$ (brs, $8 \mathrm{H}) .{ }^{13} \mathrm{C} \mathrm{NMR}\left(100 \mathrm{MHz}, \mathrm{CDCl}_{3}\right.$ ): $\delta 155.0,78.0,40.9,39.6,32.2,29.0,28.3,28.2,27.4,25.8$, 25.7. EIMS m/z: [M] $]^{+} 249$ (4), 187 (25), 171 (58), 143 (19), 114 (35), 57 (100). Spectroscopic data were in good agreement with those reported in the literature $[19,20]$.

\section{General protocol for monitoring Mono-Boc Protection of diamines by gas chromatography-mass spectrometry (GC-MS)}

The analytical GC/MS system used was an Agilent 7890A GC coupled to 5975C Mass detector Agilent Technologies, equipped with a HP-5MS capillary column (30 m x $0.25 \mathrm{~mm}$ x $0.25 \mu \mathrm{m})$ Agilent Technologies, Inc. An Agilent Technologies 7693 auto sampler was used to inject $1 \mu \mathrm{L}$ of a solution sample. The ionization energy was $70 \mathrm{eV}$ with a mass range of 30 to 800 $\mathrm{m} / \mathrm{z}$. The initial temperature of the column was set at $70{ }^{\circ} \mathrm{C}$, held for $2 \mathrm{~min}$, and then a ramp of $40^{\circ} \mathrm{C} / \mathrm{min}$ to $250^{\circ} \mathrm{C}$. The temperature of the injector was set at $250{ }^{\circ} \mathrm{C}$, and the detector at $230^{\circ} \mathrm{C}$. The flow rate of the carrier gas (Helium) was $1.0 \mathrm{~mL} /$ min injected with a gas dilution of 1:50. Identification of the individual components was based on comparison with the mass spectra library (NIST98).

\section{Acnowledgments}

Our work in this area is supported by Consejo Nacional de Ciencia y Tecnología (CONACyT Grant 128943), Dirección General de Educación Superior Tecnológica (DGEST Grant 5152.13-P) and PROMEP CA ITTIJ-CA-5. We thank CONACyT for ITT NMR facilities (Grant INFR-2011-3-173395). F. A. Servín and J. A. Romero acknowledges support from CONACyT in the form of graduate scholarships.

\section{References}

1. Bennani, Y. L.; Hanessian, S. Chem. Rev. 1997, 97, 3167-3195.

2. Noyori, R.; Hashiguchi, S. Acc. Chem. Res. 1997, 30, 97-102;

3. Doyle, A. G.; Jacobsen, E. N. Chem. Rev. 2007, 107, 5713-5743.

4. Bhadury, P. S.; Song, B-A.; Yang, S.; Hu, D-Y.; Xue, W. Curr. Org. Synth. 2009, 6, 380-399.

5. Connon, S. J. Chem. Eur. J. 2006, 12, 5418-5427.

6. Tsogoeva, S. B. Eur. J. Org. Chem. 2007, 1701-1716.

7. Somanathan, R.; Chávez, D.; Servin, F. A.; Romero, J. A.; Navarrete, A.; Parra-Hake, M.; Aguirre, G.; Anaya de Parrodi, C.; González, J. Curr. Org. Chem. 2012, 16, 2440-2461.

8. a) Schanz, H.-J.; Linseis, M. A.; Gilheany, D. G. Tetrahedron: Asymmetry, 2003, 14, 2763-2769; b) Ng, K.; Somanathan, R.; Walsh, P. J. Tetrahedron: Asymmetry 2001, 12, 1719-1722.

9. a) Kaik, M.; J. Gawroński, J. Tetrahedron: Asymmetry 2003, 14, 1559-1563; b) Chen, J.-R.; Lu, H.-H.; Li, X.-Y.; Cheng, L.; Wan, J.; Xiao, W.-J. Org. Lett. 2005, 7, 4543-4545; c) Fuentes de Arriba, A. L.; Seisdedos, D. G.; Simón, L.; Alcázar, V.; Raposo, C.; Morán, J. R. J. Org. Chem. 2010, 75, 8303-8306; d) Wu, C.; 
Kobayashi, H.; Sun, B.; Yoo, T. M.; Paik, C. H.; Gansow, O. A.; Carrasquillo, J. A.; Pastan, I.; Brechbiel, M. W. Bioorg. Med. Chem. 1997, 5, 1925-1934; e) Piielkow, M.; Lewinsky, R.; Christensen, J. B. Org. Synth. 2007, 84, 209-214; d) Kim, Y. K. K.; Lee, S. J.; Ahn, K. H. J. Org. Chem. 2000, 65, 7807-7813; f) Campbell, E. J.; Nguyen, S. T. Tetrahedron Lett. 2001, 42, 1221-1225; g) Zhang, Z.; Yin, Z.; Meanwell, N. A.; Kadow, J. F.; Wang, T. Org. Lett. 2003, 5, 3399-3402; h) Mitchell, J. M.; Finney, N. S. Tetrahedron Lett. 2000, 41, 8431-8434.

10. a) Cortez, N. A.; Aguirre, A.; Parra-Hake, M.; Somanathan, R. Tetrahedron: Asymmetry, 2013, 24, 1297-1302; b) Cortez, N. A.; Aguirre, G.; Parra-Hake, M.; Somanathan, R. Tetrahedron Lett. 2007, 48, 4335-4338; c) Cortez, N. A.; Aguirre, G.; Parra-Hake, M.; Somanathan, R. Tetrahedron: Asymmetry 2008, 19, 13041309; d) Cortez, N. A.; Aguirre,G.; Parra-Hake, M.; Somanathan, R. Tetrahedron Lett. 2009, 50, 2228-2231.

11. a) Kan, T.; Fukuyama, T. Chem. Commun. 2004, 353-359; b) Fukuyama, T.; Jow, C-K.; Cheung, M. Tetrahedron Lett. 1995, 36, 6373-6374; c) Fukuyama, T.; Cheung, M.; Jow, C-K.; Hidai, C. K.; Kan, T. Tetrahedron Lett. 1997, 38, 5831-5834; d) Christensen, C.; Clausen, R. P.; Begtrup, M.; Kristensen, J. L. Tetrahedron Lett. 2004, 45, 7991-7993.
12. Lee, D. W.; Ha, H-J.; Lee, W. K. Synth. Commun. 2007, 37, 737-742.

13. a) Darwish, M. O.; Wallace, A.; Clarkson, G. J.; Wills, M. Tetrahedron Lett. 2013, 54, 4250-4253; b) Sun, Y.; Liu, F.; Gou, S.; Cheng, L.; Fang, L.; Yin, R. Eur. J. Med. Chem. 2012, 55, 297306; c) Uppadine, L. H.; Keene, F. R.; Beer, P. D. J. Chem. Soc., Dalton Trans. 2001, 2188-2198.

14. Li, H.; Hao, M.-A.; Wang, L.; Liang, W.; Chen, K. Org. Prep. Proced. Int. 2009, 41, 301-307.

15. Sigma-Aldrich, Milwaukee, USA. [146504-07-6].

16. a) Xu, Y.-Q.; Yu, S.-L.; Li, Y.-Y.; Dong, Z.-R.; Gao, J.-X. Chin. Chem. Lett. 2013, 24, 527-530.

17. Takeda, T.; Terada, M. J. Am. Chem. Soc. 2013, 135, 15306-15309.

18. Pittelkow, M.; Lewinsky, R.; Christensen, J. B. Synthesis 2002, 15, 2192-2202.

19. Jobin, S.; Vézina-Dawod, S.; Herby, C.; Derson, A.; Biron, E. Org. Lett. 2015, 17, 5626-5629.

20. a) Bolognesi, M. L.; Calonghi, N.; Mangano, C.; Massoti, L.; Melchiorre, C. J. Med. Chem. 2008, 51, 5463-5467. b) Morrell, A.; Placzek, M. S.; Steffen, J. D.; Antony, S.; Agama, K.; Pommier, Y.; Cushman, M. J. Med. Chem. 2007, 50, 2040-2048. 


\title{
Nano $\mathrm{Fe}_{3} \mathrm{O}_{4}$ as Green Catalyst for Beckmann Rearrangement under Ultrasound Irradiation
}

\author{
Mostafa KarimKoshteh* and Marziyeh Bagheri \\ Department of chemistry, Faculty of Science, Urmia University, Urmia 57159-165, Iran \\ * E-mail: Mostafakarimkoshteh@gmail.com
}

Received April 5th, 2016; January 11th, 2017.

\begin{abstract}
Nano- $\mathrm{Fe}_{3} \mathrm{O}_{4}$ particles were used as a green and heterogeneous catalyst for Beckmann rearrangement under ultrasound irradiation and protic solvent condition in excellent yields. The advantage of this method was simple, inexpensive, easy work-up procedure, suppression of any side product.
\end{abstract}

Keywords: Beckmann rearrangement; Nano- $\mathrm{Fe}_{3} \mathrm{O}_{4}$ particles; Ultrasound irradiation; Ketoximes; Heterogeneous catalyst.

\section{Introduction}

Although nanocatalysts encompass several advantages over conventional catalyst systems [1], however, isolation and recovery of these tiny nanocatalysts from the reaction mixture is not easy [2]. To overcome this issue, the use of magnetic nanoparticles has emerged as a viable solution; their insoluble and paramagnetic nature enables easy and efficient separation of the catalysts from the reaction mixture with an external magnet [3]. Moreover, better control and understanding of the magnetic properties is now an essential tool [4, 5]. Nano- $\mathrm{Fe}_{3} \mathrm{O}_{4}$ particles offer potential for creation of novelty in a chemical reaction, such as a Sonogashira coupling reaction, oxidation of alcohols, Munich-type reaction, and cross-coupling Suzuki-Miyaura reaction [6]. On the other hands, shorter reaction times and solvent-free condition provided by ultrasound synthesis make it ideal for rapid reaction scouting and optimization of reaction conditions [7]. Therefore, applications for sonochemistry can be found in many areas, but sonochemical processes are most widely developed for heterogeneous reactions [8].
Resumen: Se emplearon nanopartículoas de $\mathrm{Fe}_{3} \mathrm{O}_{4}$ como catalizadores sustentables y heterogéneos para efectuar transposiciones de Beckmann en condiciones de irradiación con ultrasonido y solventes próticos con excelentes rendimientos. Las ventajas de este método es que es simple, barato, fácil de procesar y sin subproductos.

Palabras Clave: Transpocición de Beckmann; nanopartículas de $\mathrm{Fe}_{3} \mathrm{O}_{4}$; irradiación con ultrasonido; cetooxima; catálisis heterogenea.

So, combination of nano-size magnetic $\left(\mathrm{Fe}_{3} \mathrm{O}_{4}\right)$ particles as green nanocatalyst and ultrasound irradiation provided a realistic way for synthetic organic compounds [9].

The Beckmann rearrangement of ketoximes to secondary amides is an important process step in production of organic compounds [10]. For example, Beckmann rearrangement of cyclohexanone oxime produces $\varepsilon$-caprolactam. $\varepsilon$-caprolactam is a colorless solid cyclic amide. (a lactam) with the formula $\left(\mathrm{CH}_{2}\right)_{5} \mathrm{C}(\mathrm{O}) \mathrm{NH}$. Mainly all caprolactam production goes has produced nylon 6 polymer. Nylon-6 is widely used in fibers and plastics [11, 12]. Many methods have been developed for the Beckmann rearrangement, such as Ti/montmorillanite [13], $\mathrm{SOCl}_{2} / \beta$-cyclodextrin [14], pivaloylchloride [15], $\mathrm{H}_{2} \mathrm{SO}_{4} / \mathrm{Nano}$ $\mathrm{SiO}_{2}[16]$. However, some of these methods suffer from different disadvantages such as tedious work-up procedure, drastic reaction conditions, long reaction times, undesired chemical yields and use of expensive and toxic reagents. Therefore, a milder, more selective, non-hazardous and inexpensive reagent is still required for such transformation [17].

In this article, we have arrived at a method that produces secondary amides in an ecologically responsible method, in which no aggressive reagents and non-hazardous solvents are used (Scheme 1).

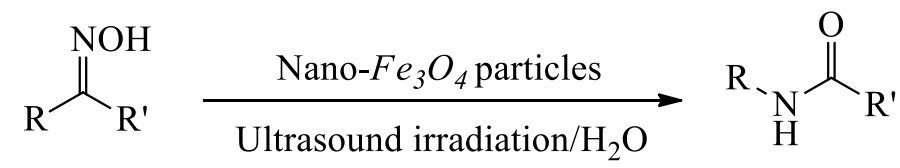

$$
\begin{aligned}
& \mathrm{R}, \mathrm{R}^{\prime}=\mathrm{CH}_{3}, \mathrm{Aryl}
\end{aligned}
$$

Scheme1. Process for synthesis secondary amides. 


\section{Experimental procedure:}

\subsection{Chemicals and apparatus}

Sonication was performed by using a Cole Palmer high intensity ultrasonic processor $(600 \mathrm{~W}, 20 \mathrm{KHz})$ via a micro-tip probe and $30 \%$ amplitude. Nano- $\mathrm{Fe}_{3} \mathrm{O}_{4}$ particles and Oximes are prepared with high purity according to the reported procedures in the literature [18, 19]. Melting points were determined by Philip-Harris is melting point apparatus and are uncorrected. IR spectra were recorded on a Thermo Nicolet Nexus 670 FT-IR spectrophotometer. ${ }^{1} \mathrm{H}$ and ${ }^{13} \mathrm{C}$ NMR spectra were recorded on a $300 \mathrm{MHz}$ Bruker Avance spectrometer in 300.13 and 75.46 $\mathrm{MHz}$ as $\mathrm{CDCl}_{3}$ solution. The $J$ values are in Hertz and the chemical shifts are expressed in ppm downfield from internal TMS. XRD and SEM spectra were recorded on Philips X'pert PW3040/60 and MIRA3 TESCAN, respectively. All yields refer to isolated pure products. TLC using silica gel $60 \mathrm{GF}_{254}$ aluminum sheet was applied for determination of the purity of substrates and products as well as monitoring the reaction.

\section{Method, General procedure for synthesis \&-caprolactam of cyclohexanone oxime with nano $\mathrm{Fe}_{3} \mathrm{O}_{4}$ under ultrasound irradiation:}

Nano $\mathrm{Fe}_{3} \mathrm{O}_{4}$ (106.7gr, 0.5mol) and cyclohexanone oxime (113.2gr, 1mol) was ground in a mortar for 10 minutes, completely mixture together, then add to $10 \mathrm{ml} \mathrm{H}_{2} \mathrm{O}$ in a round bottom flask equipped with a magnetic stirrer. The stirred reaction mixture was irradiated with ultrasound waves at $60{ }^{\circ} \mathrm{C}$. Sonication was continued for $45 \mathrm{~min}$, and the progress of the reaction was monitored by TLC (eluent: $\mathrm{CCl}_{4} / \mathrm{Et}_{2} \mathrm{O}(5 / 2)$ ). At the end of the reaction, the mixture was filtered in the presence of an efficient magnetic bar and separate nanocatalyst then extracted with diethyl ether $(3 \times 5 \mathrm{~mL})$. The extracts were combined and dried over $\mathrm{Na}_{2} \mathrm{SO}_{4}$. After evaporation of the solvent the $\varepsilon$-caprolactam was obtained, in 98\% yield (110.9gr, Table 2: entry 1).

\subsection{Spectral data of selected products:}

\&-caprolactam (Table2,entry1). White solid, m.p. $68-70^{\circ} \mathrm{C}$. IR $\left(\mathrm{KBr}, v_{\max }\right): 3294,3196,3083,3045,1665,1599,1538,1489$, 1393, 1324, 1265, 1042, 999.9, 908, 761, 694, 534, $506 \mathrm{~cm}^{-1}$.; ${ }^{1} \mathrm{HNMR}\left(300 \mathrm{MHz}, \mathrm{CDCl}_{3}, \delta \mathrm{ppm}\right): 1.64-1.85$ (m, 6H), 2.33$2.47(\mathrm{~m}, 2 \mathrm{H}), 3.02(\mathrm{~d}, 2 \mathrm{H}, J=3.9), 6.59(\mathrm{~S}, 1 \mathrm{H})$; ${ }^{13} \mathrm{C}$ NMR $(75$ $\left.\mathrm{MHz}, \mathrm{CDCl}_{3}, \delta \mathrm{ppm}\right): 23.16,29.63,30.56,36.56,42.91,77.45$, 179.34.

N-(4-Aminophenyl) acetamide (Table 2, entry3). White solid, m.p. $165^{\circ} \mathrm{C}$. IR (KBr, $\left.v_{\max }\right): 3358,3231,3038,1654,1549$, 1513, 1321, 1257, 1015, 834, $522 \mathrm{~cm}^{-1}$.; ${ }^{1} \mathrm{HNMR}(300 \mathrm{MHz}$, $\mathrm{CDCl}_{3}, \delta \mathrm{ppm}$ ): 2.14 (s, 3H, $\left.\mathrm{CH}_{3}\right), 3.49$ (bs, 2H, $\mathrm{NH}_{2}$ ), 6.64 (d, $J=8.1 \mathrm{~Hz}, 2 \mathrm{H}, \mathrm{Ar}), 6.66(\mathrm{~s}, 1 \mathrm{H}, \mathrm{NH}), 7.26$ (d, $J=12,2 \mathrm{H}, \mathrm{Ar})$.; ${ }^{13} \mathrm{C}$ NMR (75 MHz, $\left.\mathrm{CDCl}_{3}, \delta \mathrm{ppm}\right): 24.27,115.40,116.74$, $122.21,144.3,169$.
Acetanilide (Table 2, entry 2). White solid, m.p. $114^{\circ} \mathrm{C}$. IR $\left(\mathrm{KBr}, v_{\max }\right)$ : 3294, 1662, 1602, 1551, 1493, 755, $698 \mathrm{~cm}^{-1}$; ${ }^{1} \mathrm{HNMR}\left(300 \mathrm{MHz}, \mathrm{CDCl}_{3}, \delta \mathrm{ppm}\right): 2.12$ (s, 3H), 7.08 (t, 1H, $J$ $=8.0 \mathrm{~Hz}), 7.23(\mathrm{t}, 2 \mathrm{H}, J=8.0 \mathrm{~Hz}), 7.52(\mathrm{~d}, 2 \mathrm{H}, J=8.0 \mathrm{~Hz}), 8.54$ (br. s, $1 \mathrm{H}, \mathrm{NH}) . ;{ }^{13} \mathrm{C} \mathrm{NMR}\left(75 \mathrm{MHz}, \mathrm{CDCl}_{3}, \delta\right.$ ppm): 168.9, 138.1, 128.8, 124.2, 120.2, $24.1\left(\mathrm{CH}_{3}\right)$.

\section{Results and discussion}

Catalyzed organic transformations in the aqueous reaction medium are one of the ideal solutions for the development of green and sustainable protocols [20]. However, the execution of many organic reactions in water is not simply due to the inherent limitation of solubility of non-polar reactants in polar aqueous medium [21]. Which can be overcome by using ultrasound and microwave irradiation conditions [22]. Thus, when we applied nanocatalyst with ultrasound irradiation in the water medium, seems to be the perfect way to reach highly efficient chemical process.

Among nanomaterials magnetic nanoparticles are of more interest to chemical researchers owing to their praiseworthy magnetic, catalysis, photo catalysis and environmental remediation properties [23]. While talking about, various magnetic nanoparticles, magnetite $\left(\mathrm{Fe}_{3} \mathrm{O}_{4}\right)$ has been used for a several wide number of applications due to its super paramagnetic properties [24, 25].

The literature review shows that some methods such as chemical synthesis [26], thermal decomposition [27], hydrothermal synthesis [28], microwave assisted [29] synthesis is widely used to produce pure $\mathrm{Fe}_{3} \mathrm{O}_{4}$ particles due to its ability to control the particle size, size distribution and morphology through systematic monitoring of the reaction parameters. So we prepared Nano- $\mathrm{Fe}_{3} \mathrm{O}_{4}$ particles with the chemical synthesis method and structure of nanoparticle elucidation was carried out by FT-IR, XRD and scanning electron microscopy (SEM).

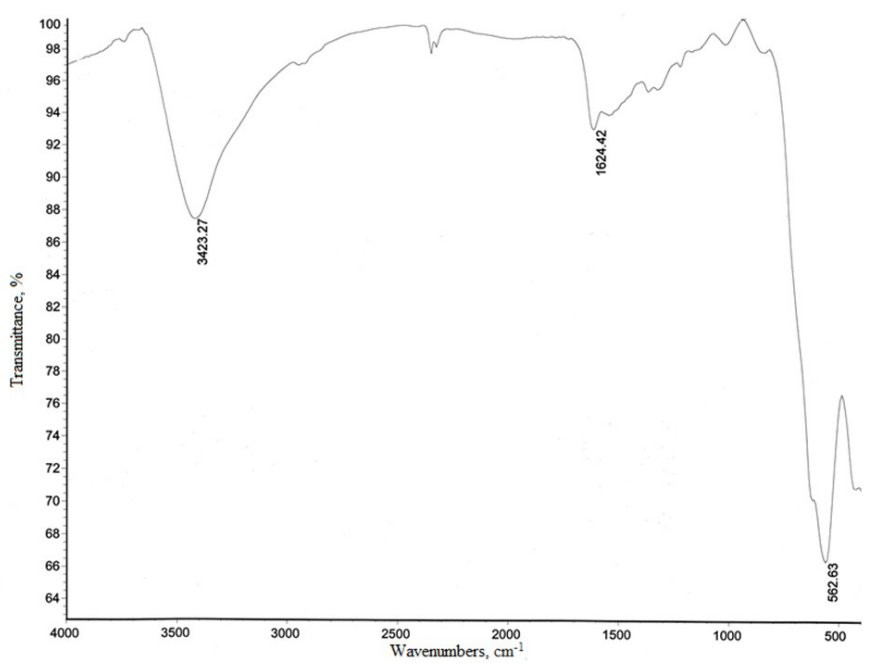

Figure 1. Infrared spectra of the nano $\mathrm{Fe}_{3} \mathrm{O}_{4}$ 


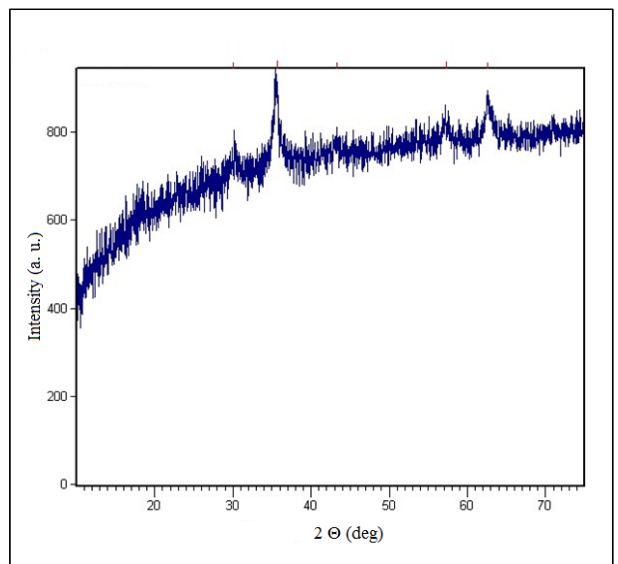

(A)

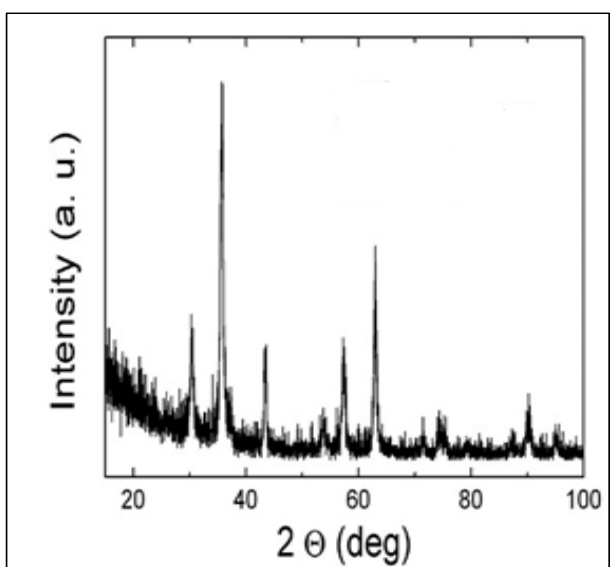

(B)

Figure 2. (A) XRD pattern of obtaining samples, (B) standard diffraction spectrum (JCPDS: 65-3107).

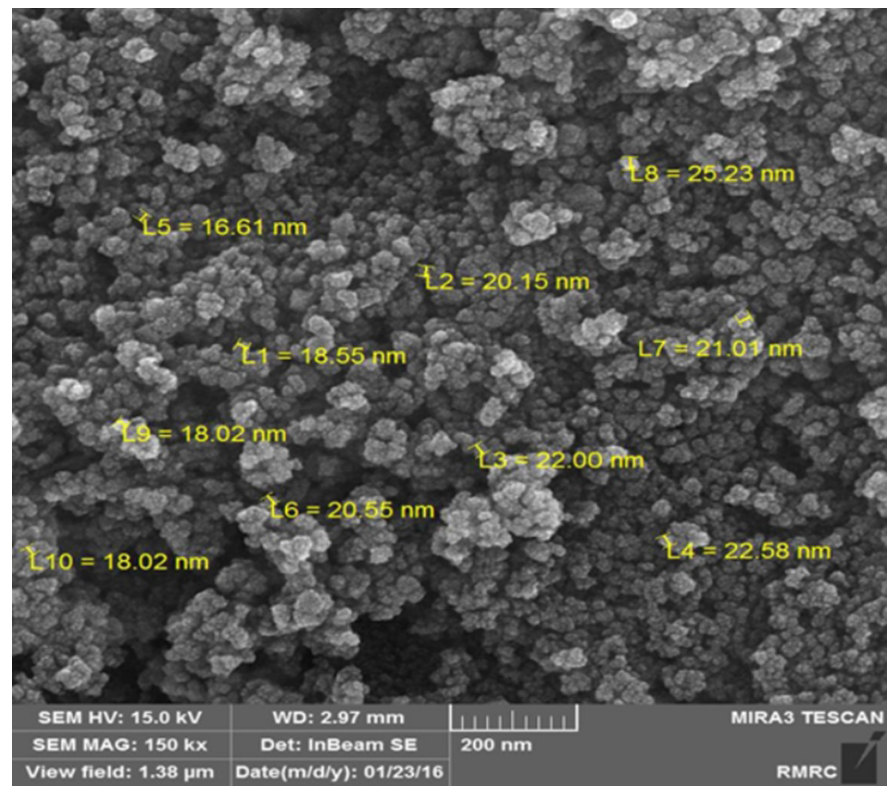

Figure 3. SEM pattern of obtaining nano $\mathrm{Fe}_{3} \mathrm{O}_{4}$.

The FT-IR spectra of the synthesized $\mathrm{Fe}_{3} \mathrm{O}_{4}$ nano particles (Figure1) show the intense peaks at $562 \mathrm{~cm}^{-1}$ band, that is due to the stretching vibration mode associated with the metal-oxygen absorption band ( $\mathrm{Fe}-\mathrm{O}$ bonds in the crystalline lattice of $\mathrm{Fe}_{3} \mathrm{O}_{4}$ ) [30].

Figure 2 shows X-ray diffraction patterns of synthesized $\mathrm{Fe}_{3} \mathrm{O}_{4}$ nanoparticles. Comparing XRD pattern of synthesized particles with the standard diffraction spectrum (JCPDS: 653107 ), the synthesized product is crystalline $\mathrm{Fe}_{3} \mathrm{O}_{4}$ and the average particle size was calculated to be $16.81 \mathrm{~nm}$ using the Sherrer's equation [31].

Therefore XRD particle size calculations are not quite accurate, justifying SEM observations. Corresponding SEM micrograph is shown in Figure 3, where particles are homogeneously dispersed. Particles are almost spherical with $20 \mathrm{~nm}$ average diameter.

In continuation of our efforts towards the development of application Nano- $\mathrm{Fe}_{3} \mathrm{O}_{4}$ particles in organic synthesis [32] and on the other hand, ultrasound irradiation as an unconventional energy source has been widely used to perform many kinds of chemical reactions and numerous reviews and papers demonstrated its importance $[33,34,35]$. We decided to synthesis secondary amides of ketoximes at present of Nano- $\mathrm{Fe}_{3} \mathrm{O}_{4}$ particles as green nanocatalyst under ultrasound irradiation as effective method.

Although the Beckmann rearrangement is carried out with $\mathrm{FeCl}_{3}$ [36] and Silferc (anhydrous $\mathrm{FeCl}_{3}$ supported on silica-gel by co-grinding method) [37], however, the reported methods suffer from the limitation in long reaction times, tedious workup procedures.

We first optimized reaction conditions with cyclohexanone oxime compound by nano $\mathrm{Fe}_{3} \mathrm{O}_{4}$ under ultrasound irradiation. As shown in the experimental section, before adding $\mathrm{H}_{2} \mathrm{O}$ as a green solvent to reaction, substrate and nanocatalyst grinding in a mortar for a moment, that increase the number of collisions between $\mathrm{OH}$ groups of ketoximes and nanoparticle surface, that will increase the reaction rate. The results showed that using a 0.5 molar equivalent of nano $\mathrm{Fe}_{3} \mathrm{O}_{4}$ per molar equivalent of the oxime and $30 \%$ power amplitude of the ultrasound was the best optimum for synthesis $\varepsilon$-caprolactam. The reaction was completed in $45 \mathrm{~min}$ and $\varepsilon$-caprolactam was obtained in $98 \%$ yield (Table 1).

As described in Table 1, the higher yield, shorter reaction time and milder reaction condition gained under ultrasonic irradiation over in the other reaction condition present in the table (oil bath and reflux), even with a mixture of $\mathrm{H}_{2} \mathrm{O}(2 \mathrm{ml})$ / $\mathrm{CH}_{3} \mathrm{CN}(2 \mathrm{ml})$ for increase solve cyclohexanone oxime in solvent. that is a result of the implosive collapse of the cavitation period of the sound waves. When the formed bubbles burst, it results in high temperature and high pressure which facilitate the intermolecular reaction [38]. 
TABLE 1. Optimization experiments for synthesis $\varepsilon$-caprolactam with nano $\mathrm{Fe}_{3} \mathrm{O}_{4}$ under ultrasound irradiation using $1 \mathrm{mmol}$ of cyclohexanone oxime.

\begin{tabular}{|c|c|c|c|c|c|c|}
\hline Entry & $\begin{array}{c}\text { Reaction } \\
\text { components }\end{array}$ & $\begin{array}{l}\text { Molar } \\
\text { ratio }\end{array}$ & Condition $^{\text {a }}$ & $\begin{array}{c}\text { Time, } \\
\min \end{array}$ & $\begin{array}{c}\text { Conversion }^{\mathrm{b}} \text {, } \\
\%\end{array}$ & $\begin{array}{c}\text { Yields, } \\
\%\end{array}$ \\
\hline 1 & Oxime /nano $\mathrm{Fe}_{3} \mathrm{O}_{4}$ & $1 / 0.5$ & $\mathrm{H}_{2} \mathrm{O} / \mathrm{US}$ - irradiation & 45 & 100 & 98 \\
\hline 3 & Oxime /nano $\mathrm{Fe}_{3} \mathrm{O}_{4}$ & $1 / 0.25$ & $\mathrm{H}_{2} \mathrm{O} / \mathrm{US}$ - irradiation & 30 & 68 & 50 \\
\hline 4 & Oxime /nano $\mathrm{Fe}_{3} \mathrm{O}_{4}$ & $1 / 1$ & Solvent-free/oil bath & 60 & 35 & 14 \\
\hline 7 & Oxime /bulk $\mathrm{Fe}_{3} \mathrm{O}_{4}$ & $1 / 1$ & $\mathrm{H}_{2} \mathrm{O} / \mathrm{US}$ - irradiation & 50 & $<1$ & $<1$ \\
\hline
\end{tabular}

${ }^{\text {a }}$ Temperature of oil bath was $70-80{ }^{\circ} \mathrm{C}$ and irradiation with ultrasound was carried out under $30 \%$ amplitude.

${ }^{\mathrm{b}}$ monitored by TLC.

In routine chemical reaction applied nanocatalyst in solvent less condition, occur more efficiently and with more selectivity compared to reaction carried out in a solvent [39] (table 1, entry 4,5).)

Likewise, we have applied this protocol for the rearrangement of aliphatic, aromatic ketoximes and the result summarized in Table 2. Both activated and deactivated aromatic ketoximes were converted to corresponding amides.
On examination of Table 2 some observations can be made. In all cases only one of the two possible amides were recovered. However, in case of aliphatic and cyclic systems, the reaction proceeds with quantitative conversion in reasonable time (35$45 \mathrm{~min}$ ). Moreover the results showed that migration of an alkyl group predominates over that of an aryl group (entry 5).

A case study in table 3 shows that aldoximes were deoximation completely to the corresponding carbonyl compounds under the experimental conditions.

TABLE 2. Beakmann rearrangement of ketoximes with nano $\mathrm{Fe}_{3} \mathrm{O}_{4}$ system. $^{\text {a }}$

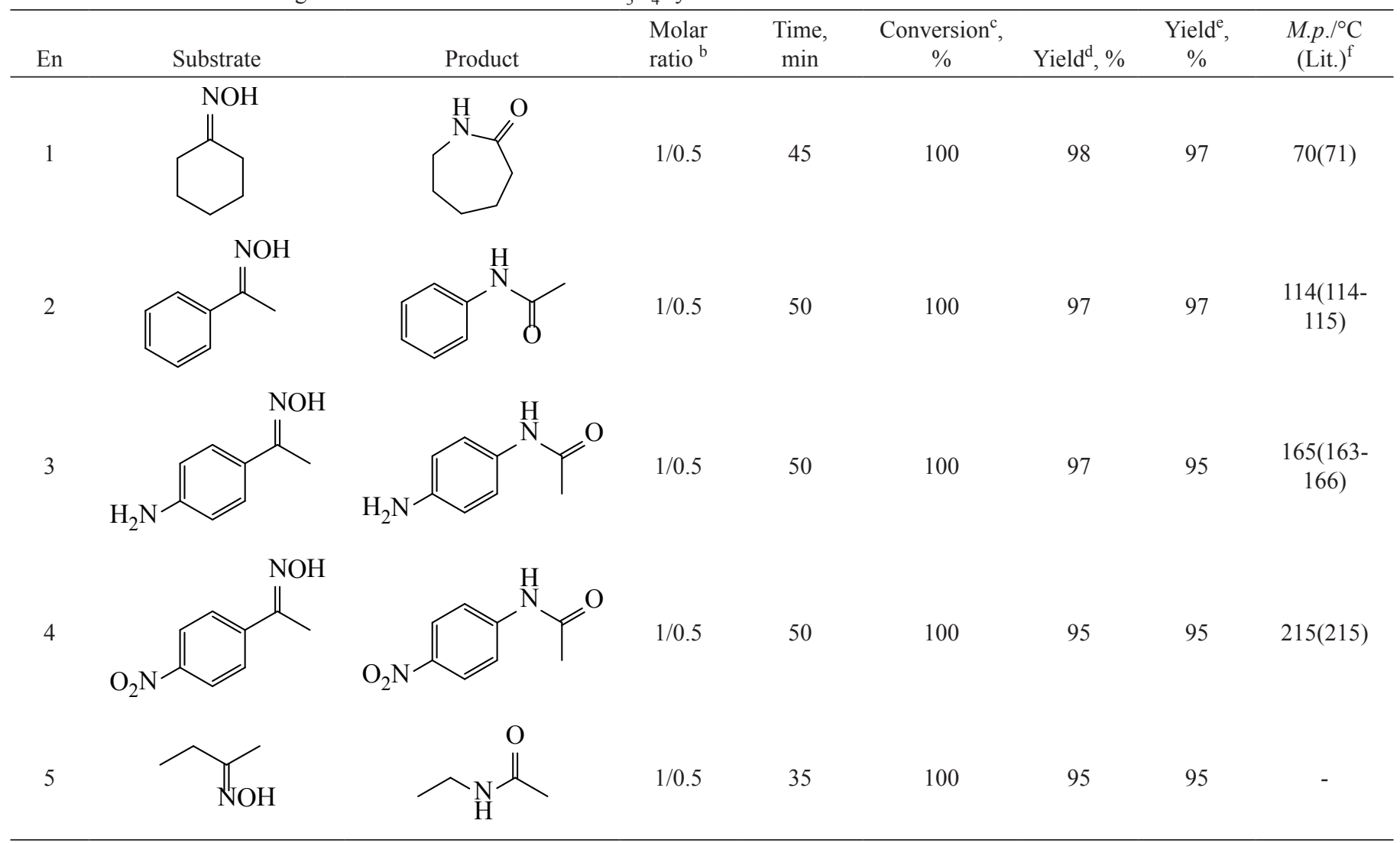

${ }^{\text {a }}$ All reaction carry out under ultrasound irradiation( $30 \%$ amplitude).

${ }^{\mathrm{b}}$ Molar ratio as Sub./Nano Catalyst.

${ }^{\mathrm{c}}$ monitored by TLC.

\footnotetext{
${ }^{\mathrm{d}}$ Determined after work-up procurer.

${ }^{\mathrm{e}}$ Yields refer to isolated pure products from $5 \mathrm{~g}$ substrate.

${ }^{\mathrm{f}}$ Lit. m.p. obtained from ref. 41-44.
} 
TABLE 3. Deoximation of aldoximes to corresponding carbonyl compounds. ${ }^{\text {a }}$

\begin{tabular}{|c|c|c|c|c|c|c|}
\hline En & Substrate & Product & $\begin{array}{l}\text { Molar } \\
\text { ratio }^{b}\end{array}$ & Time, $\min$ & Yield $^{\mathrm{c}}, \%$ & Yield $^{\mathrm{d}}, \%$ \\
\hline 2 & & & $1 / 0.5$ & 45 & 96 & 95 \\
\hline 3 & & & $1 / 0.4$ & 41 & 98 & 97 \\
\hline 4 & & & $1 / 0.5$ & 35 & 98 & 95 \\
\hline 5 & & & $1 / 0.5$ & 45 & 97 & 95 \\
\hline 6 & & & $1 / 0.5$ & 35 & 98 & 98 \\
\hline
\end{tabular}

${ }^{a}$ All reaction carry out under ultrasound irradiation(30\% amplitude).

${ }^{\mathrm{b}}$ Molar ratio as Sub./Nano Catalyst.
${ }^{\mathrm{c}}$ Determined after work-up procurer.

${ }^{\mathrm{d}}$ Yields refer to isolated pure products from $5 \mathrm{~g}$ substrate.
Also for showing the advantages of this method, we applied the experiments for converting of five grams of some oxime compound used in this protocol and the result shown in the tables 2 and 3.

In continuous for application reported protocol, ketoximes selective rearrangement to the corresponding amides in the presence of aldoximes under the experimental conditions (Scheme 2).
In Beckmann rearrangement hydroxyl group of a ketoxime is removed by the acidic catalyst and generate a divalent sp-hybridized azacation. Were this to occur, both carbon substitutes would be candidates for the subsequent 1, 2-shift, followed by hydrolysis, an amide is formed. The present results thus also indicate the migration of the group anti to the oxime hydroxyl group [40].<smiles>CC(=O)Nc1ccc([N+](=O)[O-])cc1</smiles>

Scheme 2. Competitive reaction of aldoxime and ketoxime in the presence of nano $\mathrm{Fe}_{3} \mathrm{O}_{4}$ (approximately determined from TLC). 


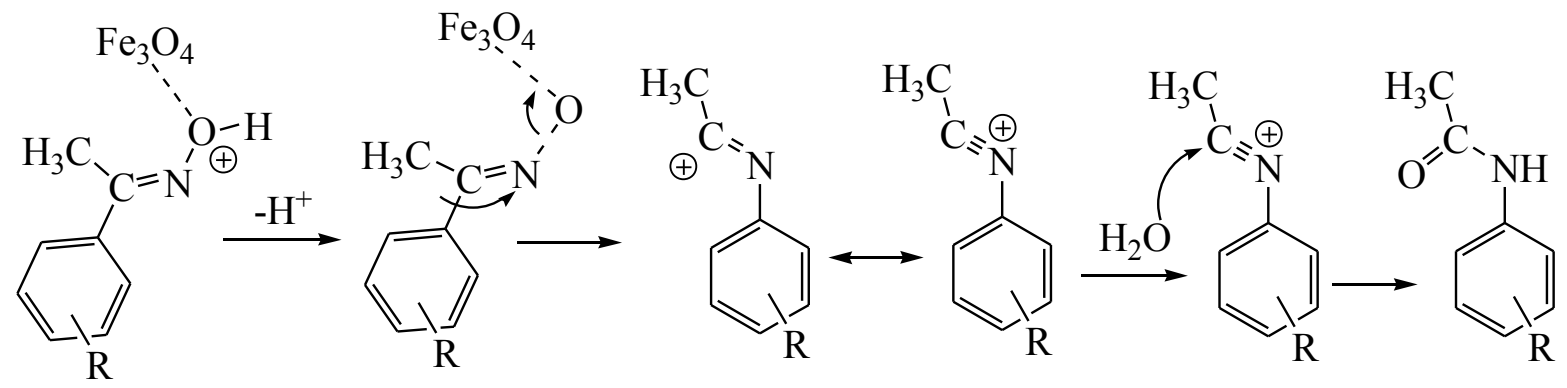

Scheme 3. A plausible mechanism for synthesis $\varepsilon$-caprolactam.

As listed in Table 2, for substrate with less than 5 grams, substrates bearing electron-donating groups in the para-position of the phenyl ring (Entry 3) were found to undergo 1,2-migration much faster than those with electron-withdrawing functionalities (Entry 4), suggesting that when an electron-donating group is present, the ring becomes more electrostatically negative, resulting in the enhancement of the migration rate, but for substrate with more than of 5 gram scale, based on the qualitative analysis by GC-MS, the cause of reducing the yield of the amide (entry 3), could be known as a byproduct (corresponding ketone).

A plausible mechanism for the $\mathrm{Nano}-\mathrm{Fe}_{3} \mathrm{O}_{4}$ particles catalyzed Beckmann rearrangement on ketoxime to corresponding amide was illustrated in Scheme 3. The Nano- $\mathrm{Fe}_{3} \mathrm{O}_{4}$ particles facilitate the rearrangement process through co-ordination with - $\mathrm{OH}$ of ketoximes, followed by the transfer of $\mathrm{R}$ group.

In continuing to evaluate the recyclability and reusability of the $\mathrm{Fe}_{3} \mathrm{O}_{4}$ nanocatalyst, we performed the Beckmann rearrangement of cyclohexanone oximes with nanocatalyst under the optimized reaction conditions. After the completion of the reaction, the catalyst was easily separated from the reaction system and the recovered $\mathrm{Fe}_{3} \mathrm{O}_{4}$ nanocatalyst was washed by a sufficient amount of water and acetone. Finally, the nanocatalyst was dried in an oven at $50^{\circ} \mathrm{C}$ overnight before the use for next catalytic cycle, and reused for four consecutive runs, the result showed that the $\mathrm{Fe}_{3} \mathrm{O}_{4}$ nanocatalyst could be effectively recycled and reused up (the conversions, yield and selectivity's were $100 \%, 98 \%$ and $100 \%$ for 1 st run; $98 \%, 95 \%$ and $100 \%$ for 2 nd run; $97 \%, 89 \%$ and $95 \%$ for 3rd run; $90 \%, 86 \%$ and $95 \%$ for 4 th run).

\section{Conclusion}

In this paper, we have shown the application of Nano- $\mathrm{Fe}_{3} \mathrm{O}_{4}$ particles efficiently catalyzed synthesis secondary amides in high yields under green solvent conditions. Simplicity, excellent yields, mildness and eco-friendly aspects of this synthetic protocol are the advantages which make this system an effective way to the present methodologies in this area.

\section{Acknowledgments:}

The authors thank Professor Behzad Zeynizadeh for inspiration and gratefully acknowledge the financial support of this work by the research council of Urmia University and Nano Research Center.

\section{References}

1. Naeimi, H.; Rabiei, Kh.; Rashid, Z. Current Organic Chemistry. 2016, 20, 316.

2. Hasty, J. K.; Ponnurangam, S.; Turn, S.; Somasundaran, P.; Kim, T.; Mahajan, D. Fuel. 2016, 164, 339.

3. Kefayati, H.; Bazargard, S. J.; Vejdansefat, P.; Shariati, Sh.; Kohankar, A. M. Dyes and Pigments. 2016, 125, 309.

4. Rossi, L. M.; Costa, N. J. S.; Silva, F. P.; Wojcieszak, R. Green Chem., 2014,16, 2906.

5. Pourjavadi, A.; Hosseini, S. H.; Doulabi, M.; Fakoorpoor, S. M.; Seidi, F. ACS Catal., 2012, 2, 1259.

6. Gawande, M. B.; Branco, P. S.; Varma, R. S. Chem. Soc. Rev., 2013, 42, 3371.

7. Seok, S.; Hussain, M. A.; Park, K. J.; Kim, J. W.; Kim, D. H. Ultrasonics Sonochemistry.2016, 28, 178.

8. Ngo, Th. H.; Berndt, H.; Lentz, D.; Reissig, H. U. J. Org. Chem., 2012, 77, 9676.

9. Fekri, L. Z.; Nikpassand, M.; Pour, K. H. Current Organic Synthesis. 2015, 12, 76.

10. Donaruma, L. G.; Heldt, W. Z. Org. React. 1960, 11, 1.

11. You, K.; Zhao, F.; Long, X.; Liu, P.; Ai, Q.; Luo, H. Frontiers of Chemical Science and Engineering. 2012, 6, 389.

12. Ritz, J.; Fuchs, H.; Kieczka, H.; Moran, W. C. "Caprolactam", Ullmann's Encyclopedia of Industrial Chemistry, Weinheim, Wiley-VCH, 2005.

13. Mitsudome, T.; Matsuno, T.; Sueoka, S.; Mizugaki, T.; Jitsukawa, K. Tetrahedron Lett. 2012, 53, 5211.

14. Patil, D.; Dalal, D. Syn.Commun. 2013, 43, 118.

15. Srinivasa, R. N.; Buchi, R. R.; Mukkanti, K. Tetrahedron Lett. 2011, 52, 4888.

16. Bagheri, M.; KarimKoshteh, M. Iranian Journal of catalyst. 2013, 3, 27.

17. Singh, S.; Saquib, M.; Singh, M.; Tiwari, J.; Tufail, F.; Singh, J. New J. Chem. 2016, 40, 63. 
18. Mascolo, M. C.; Pei, Y.; Ring, T. A. Materials. 2013, 6, 5549.

19. Karimkoshteh, M.; Bagheri, M.; Zeynizadeh. B. Nano. Chem. Res. 2016, 1, 57.

20. Nasrollahzadeh, M.; Sajadi, S. M. Journal of Colloid and Interface Science. 2016, 465, 121.

21. Butler, R. N.; Coyne, A. G. J. Org. Chem., 2015, 80, 1809.

22. Nikpassand, M.; Fekri, L. Z.; Farokhian, P. Ultrasonics Sonochemistry. 2016, 28, 341.

23. Yoon, T. J.; Lee, W.; Oha, Y. S.; Lee, J. K. New J. Chem., 2003, $27,227$.

24. Wu, Zh. Sh.; Yang, Sh.; Sun, Y.; Parvez, Kh.; Feng, X.; Müllen. K. J. Am. Chem. Soc., 2012, 134, 9082.

25. Firouzabadi, H.; Iranpoor, N.; Gholinejad, M.; Hoseini, J. Advanced Synthesis \& Catalysis, 2011, 353, 125.

26. Hyeon, T. Chem. Commun., 2003, 927.

27. Hyeon, T.; Lee, Su. S.; Park, J.; Chung, Y.; Na, H. B. J. Am. Chem. Soc., 2001, 123, 12798.

28. Daou, T. J.; Pourroy, G.; Bégin-Colin, S.; Grenèche, J. M.; U1haq-Bouillet, C.; Legaré, P.; Bernhardt, P.; Leuvrey , C.; Rogez, G. Chem. Mater., 2006, 18, 4399.

29. Cao, Sh. W.; Zhu, Y. J.; Ma, M. Y.; Li , L.; Zhang, L. J. Phys. Chem. C. 2008, 112, 1851.

30. Ahn, Y.; Choi, E.J.; Kim, E.H. Rev. Adv. Mater. Sci. 2003, 5, 477.

31. Nogami, M.; Moriya, Y. J. Non-Cryst. Solids 1980, 37, 191.

32. Zeynizadeh, B.; Karimkoshteh, M. Journal of Nanostructure in Chemistry. 2013, 3, 57.
33. Reddy, M. V.; Reddy, A. V. S.; Jeong, Y. T. Research on Chemical Intermediates. 2016, 42, 4893.

34. Shabalala, N.; Maddila, S.; Jonnalagadda, S. B. New J. Chem., 2016, 40, 5107.

35. Sathishkumar, P.; Mangalaraja, R. V.; Anandan, S. Renewable and Sustainable Energy Reviews 2016, 55, 426.

36. Khodaei, M. M.; Meybodi, F. A.; Rezai, N.; Salehi, P. Synth. Commun. 2001, 31, 2047.

37. Khadilkar, M. B.; Upadhyaya, D. J. Synthetic Communications, 2002, 32, 1867.

38. GhafariKhaligh, N.; Shirini, F. Ultrason. Sonochem. 2013, 20, 19-25.

39. Karimkoshteh, M.; Bagheri, M.; Zeynizadeh, B. Nano. Chem. Res., 2016, 1, 57.

40. Narahari, S. R.; Reguri, B. R.; Mukkanti, K. Tetrahedron Letters. 2011, 52, 4888.

41. Aldrich Handbook of Fine Chemicals and Laboratory Equipment, (Aldrich Chem\& Co) 2003-2004.

42. Sharghi, H.; Hosseini, M. Synthesis. 2002, 1057.

43. Lide, D. R. CRC Handbook of Chemistry and Physics, 87th ed., CRC Press, 2006.

44. Furniss, B. S.; Hannaford, A. J.; Rogers, V.; Smith, P. W. G.; Tatchell, A. R. Qualitative organic analysis; physical constant of organic compounds. In Vogel's Textbook of Practical Organic Chemistry, 4th ed., Longman: London \& New York, 1978, p. 1113. 


\title{
Fast and Green Method to Synthesis of Quinolone Carboxylic Acid Derivatives Using Giant-Ball Nanoporous Isopolyoxomolybdate as Highly Efficient Recyclable Catalyst in Refluxing Water
}

\author{
Yahya Mirzaie, ${ }^{1}$ Jalil Lari, ${ }^{1}$ Hooshang Vahedi, ${ }^{1}$ Mohammad Hakimi, ${ }^{1}$ Ahmad Nakhaei ${ }^{*}$ \\ and Abdolreza Rezaeifard ${ }^{3}$ \\ 1 Department of Chemistry, Payame Noor University, 19395-3697 Tehran, Iran \\ 2 Young Researchers and Elite Club, Mashhad Branch, Islamic Azad University, Mashhad, Iran \\ E-mail: nakhaei a@yahoo.com, nakhaei a@mshdiau.ac.ir \\ 3 Catalysis Research Laboratory, Department of Chemistry, Faculty of Science, University of Birjand, Birjand, $97179-414$ Iran
}

Received October 10th, 2016; Accepted January 11th, 2017.

\begin{abstract}
Various potentials antibacterial fluoroquinolone compounds were prepared by the direct amination of 7-halo-6- fluoroquinolone-3-carboxylic acids with variety of piperazine derivatives and $(4 \mathrm{aR}, 7 \mathrm{aR})$-octahydro-1H-pyrrolo[3,4-b] pyridine using $\left(\mathrm{NH}_{4}\right)_{42}$ $\left[\mathrm{Mo}^{\mathrm{VI}}{ }_{72} \mathrm{MoV}_{60} \mathrm{O}_{372}\left(\mathrm{CH}_{3} \mathrm{COO}\right)_{30}\left(\mathrm{H}_{2} \mathrm{O}\right)_{72}\right]$, a Keplerate-type giant-ball nanoporous isopolyoxomolybdate, as a catalyst in refluxing water. The results showed that this catalyst acts as effective catalyst and the reaction proceeded more easily and gave the highest yields of the products in short reaction time under refluxing water. Short reaction times, simple isolation of the products, and usage of eco-friendly catalysts are some features of this procedure. In addition, the catalysts was easily recovered and used in multiple catalytic cycles. This material was prepared according to a previously published literature procedure using inexpensive and readily available starting materials.
\end{abstract}

Keywords: Fluoroquinolone derivatives; fast and green synthesis; Keplerate $\left\{\mathrm{Mo}_{132}\right\}$.

\section{Introduction}

Fluoroquinolones have been a class of important of synthetic antibacterial agents which are widely used in clinic for the treatment of infectious diseases [1,2]. These compounds act with an excellent activity against gram-negative and comparatively moderate against gram-positive bacteria [3-7]. Mechanism of action of these compounds is based on inhibition of an enzyme essential for bacterial DNA replication called DNA gyrase [8]. It also appears that some fluoroquinolones possess anticancer and even anti-HIV activities [9-11].

Despite there are still certain undesired events in usage of fluoroquinolones for therapeutic purposes, fluoroquinolones are one of the most important antimicrobial agents with many advantages for clinical use. Therefore there has been a growing interest in the structure modification of the fluoroquinolone skeleton and in the development of its new derivatives with increasing efficacy to prevention of hospital-acquired infections induced by fluoroquinolone-resistant pathogens [12-14]. Recent studies have shown that substituents at the 7-position of the fluoroquinolone framework highly affect their biological
Resumen. Se prepararon varios derivados de la fluoroquinolona con actividad antibacterial potencial por aminación directa de ácidos 7-halo-6-fluoroquinolona-3-carboxílicos con derivados de la piperazina empleando como catalizador un isopolioxomolibdato nanoporoso "giant-ball" en agua a ebullición. Los resultados demuestran que este catalizador actúa como un catalizador efectivo y que la reacción procede más fácilmente y da mejores rendimientos bajo tiempos de reacción cortos en agua a ebullición. Algunas características importantes de este método son tiempos de reacción cortos, aislamiento simple de los productos y el empleo de catalizadores amigables con el ambiente. Además, el catalizador fue fácilmente recuperado y usado en múltiples ciclos catalíticos. El material fue preparado de acuerdo a un procedimiento previamente publicado empleando materiales baratos y disponibles comercialmente.

Palabras clave: Derivados de la flouroquinolona; síntesis rápida y verde; Keplerate $\left\{\mathrm{Mo}_{132}\right\}$.

activity, antimicrobial spectrum, strength and target preferences [15]. For example, piperazinyl moieties substitution at this position of fluoroquinolones increase their basicity, lipophilicity and their ability to penetrate into cell walls which leads to a wide range of clinically beneficial fluoroquinolone such as ciprofloxacin, enrfoloxacin, levofloxacin, etc. [16-18].

Many synthetic protocols have been developed to accelerate the rate of amination of fluoroquinolones and to improve the yield [19-29]. Major drawbacks of these procedures include expensive reagents, use of large amounts of toxic organic solvents, prolonged heating and side reactions or using microwave. These disadvantages are not acceptable in the current pharmaceutical industry. Therefore, the development of a new greener and more convenient method for the synthesis of fluoroquinolones is highly desirable.

Giant nanosized porous Keplerate-type POMs was reported for the first time by Müller and co-workers [30]. The Keplerate and giant nanosized porous POMs show unique features which can be considered as the basis of a new type of nanochemistry and nanomaterials science [31,32]. They find a large variety of applications in principal and applied science, such as 
in modelling passive cation transport through membranes, encapsulation, nanoseparation chemistry, and magnetic and optics properties [33,34].

According to the excellent acidic properties of solid polyoxometalate acids, in the last three decades, many applications as the useful and versatile acid catalysts have found in these structures [35]. Polyoxometalate acids are generally solids that are unsolvable in non-polar solvents but extremely soluble in polar ones and they can be used in both homogeneous and heterogeneous systems. Furthermore, these structures have a number of utilities involving powerful flexibility in qualification of the acid potency, easy handling, environmental friendly, non-toxicity and facile synthesis [36,37].

As a result of global interest in the ongoing research towards the development of environmentally friendly methods for the synthesis of organic compounds especially compounds that are frequently used in current pharmaceutical industry, we report herein facile and efficient green synthesis of fluoroquinolones as potential antibacterial with short reaction time by the two-component condensation of variety amines and some 7-halo-6-fluoroquinolone-3-carboxylic acids using a Keplerate-type giant-ball nanoporous isopolyoxomolybdate, $\left\{\mathrm{Mo}_{132}\right\}$, as a new catalyst with high catalytic activity under reflux condition in high yield.
In continuation of our previous works on the application of $\left(\mathrm{NH}_{4}\right)_{42}\left[\mathrm{Mo}^{\mathrm{VI}}{ }_{72} \mathrm{Mo}^{\mathrm{V}}{ }_{60} \mathrm{O}_{372}\left(\mathrm{CH}_{3} \mathrm{COO}\right)_{30}\left(\mathrm{H}_{2} \mathrm{O}\right)_{72}\right]$, a Keplerate-type giant-ball nanoporous isopolyoxomolybdate, represented as $\left\{\mathrm{Mo}_{132}\right\}$, as a catalyst for a series of organic transformations [38-40], we report here the application of this material as highly efficient and reusable novel catalyst to promote the reaction time, and yields of fluoroquinolone derivatives from the reaction of some 7-halo-6-fluoroquinolone carboxylic acid $\mathbf{1}$ and amine $\mathbf{2}$ in refluxing water under clean synthesis (Scheme 1). The diameter of this ball-shaped POM which calculated theoretically is $2.9 \mathrm{~nm}[31,32]$. For the first time this molybdenum cluster has been characterized by the TEM image by Polarz et al. [33]. The TEM picture clearly shows a periodic structure with an average size approximately $3 \mathrm{~nm}$ diameter. This experimentally obtained diameter fits nicely with the theoretical value for the inner diameter of the ball-shaped POM [31, 32].

\section{Results and discussion}

The $\left\{\mathrm{Mo}_{132}\right\}$ catalyst was characterized using FT-IR and UVvisible spectroscopies as reported in our previous work [38]. The catalytic activity of this material was evaluated in the
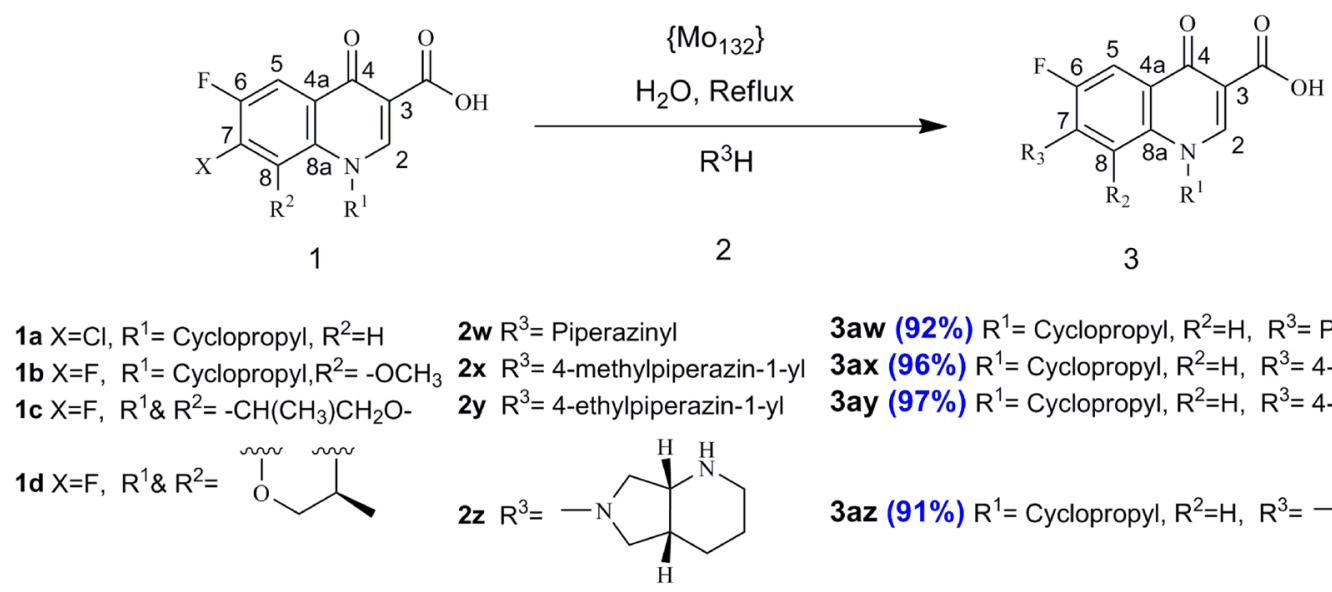

3aw $(92 \%) \mathrm{R}^{1}=$ Cyclopropyl, $\mathrm{R}^{2}=\mathrm{H}, \mathrm{R}^{3}=$ Piperazinyl

$3 a x(96 \%) R^{1}=$ Cyclopropyl, $R^{2}=H, R^{3}=4$-methylpiperazin-1-yl

3ay $(97 \%) R^{1}=$ Cyclopropyl, $R^{2}=H, R^{3}=4$-ethylpiperazin-1-yl

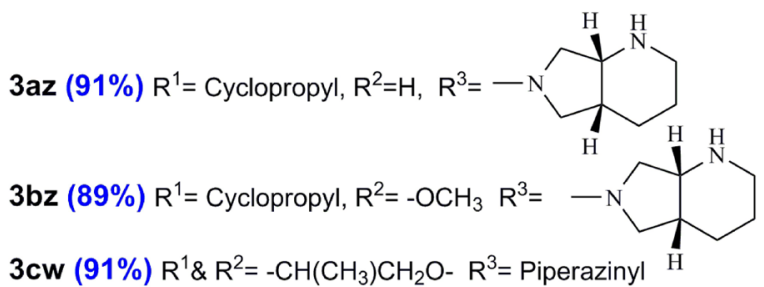

$3 \mathrm{cx}(89 \%) \mathrm{R}^{1} \& \mathrm{R}^{2}=-\mathrm{CH}\left(\mathrm{CH}_{3}\right) \mathrm{CH}_{2} \mathrm{O}-\mathrm{R}^{3}=4$-methylpiperazin-1-yl

$3 \mathrm{dw}(95 \%) \mathrm{R}^{1} \& \mathrm{R}^{2}=\stackrel{\text { O }}{\mathrm{O} \sim} \mathrm{R}^{3}=$ Piperazinyl

$3 d x(93 \%) R^{1} \& R^{2}=\stackrel{\sim}{O} \sim R^{3}=4$-methylpiperazin-1-yl

3dy $(88 \%) R^{1} \& R^{2}=\stackrel{2 \sim}{2} R^{3}=4$-ethylpiperazin-1-yl

$3 d z(94 \%) R^{1} \& R^{2}=\stackrel{O}{O}$

Scheme 1. Synthesis of fluoroquinolone derivatives in the presence of $\left\{\mathrm{Mo}_{132}\right\}$ under refluxing water. 
synthesis of fluoroquinolone derivatives. At first, the synthesis of compound 3ay was selected as a model reaction to determine suitable reaction conditions. The reaction was carried out by mixture of 7-chloro-1-cyclopropyl-6-fluoro-4-oxo-1,4-dihydroquinoline-3-carboxylic acid 1a $(1 \mathrm{mmol})$ and $N$-ethylpiperazine $2 \mathbf{y}(1.5 \mathrm{mmol})$ in the presence of different amounts of $\left\{\mathrm{Mo}_{132}\right\}$, and various solvents such as $\mathrm{EtOH}, \mathrm{H}_{2} \mathrm{O}, \mathrm{MeOH}$, $\mathrm{CH}_{3} \mathrm{CN}, \mathrm{CH}_{2} \mathrm{Cl}_{2}$, and also under solvent-free conditions at different temperature (Table 1). Long reaction times (>120 min) and not so good yields ( $45 \%$ ) of the product 3 ay were obtained in the absence of the catalyst in all cases (entries 1-5). On the other hand, different amounts of the catalyst $(0.02,0.04,0.06$, 0.08 , and 0.1 ) in the presence of the solvents or solvent-free condition in various temperatures caused to improve the yields and times of the reaction. Moreover, the best results in the presence of different amounts of catalyst were in refluxing solvents. These outcomes show that catalyst, solvent, and temperature are necessary for this reaction as well polar solvents were better than other non-polars. Also, the best yields and short reaction times were obtained in $0.08 \mathrm{~g}$ of the catalyst in water at different temperature (entries 12-14). Whereas, further increase in catalyst amount to $0.1 \mathrm{~g}$, did not improve the product yield and reaction time (entry 15). Among the tested solvents and also solvent-free conditions and various amounts of the catalyst, the reaction was more facile and proceeded to give the highest yield (97\%), and short reaction time (30 $\mathrm{min})$, using 0.08 $\mathrm{g}$ of $\left\{\mathrm{Mo}_{132}\right\}$ in $\mathrm{H}_{2} \mathrm{O}(5 \mathrm{ml})$ at reflux temperature (entry 12). All subsequent reactions were carried out in these optimized conditions.

According to these results, and in order to generalize this model reaction, we developed the reaction of $\mathbf{1 a - d}$ with a range of various amines $\mathbf{2} \mathbf{w}-\mathbf{z}$ under the optimized reaction conditions. The condensation of $\mathbf{1 a - d}$ and $\mathbf{2} \mathbf{w}-\mathbf{z}$ afforded the products 3 in high yields over relatively short reaction times in

Table 1. Optimization of reaction conditions for the synthesis of compound 3ay catalyzed by $\left\{\mathrm{Mo}_{132}\right\}$.

\begin{tabular}{|c|c|c|c|c|c|}
\hline Entry & Catalyst (g) & Solvent & $\mathrm{T} /{ }^{\circ} \mathrm{C}$ & Time/min & Isolated Yield/\% \\
\hline 1 & None & $\mathrm{EtOH}$ & Reflux & 125 & 29 \\
\hline 2 & None & $\mathrm{H}_{2} \mathrm{O}$ & Reflux & 125 & 42 \\
\hline 3 & None & $\mathrm{H}_{2} \mathrm{O}$ & r.t. & 160 & 34 \\
\hline 4 & None & Solvent-free & 100 & 150 & 16 \\
\hline 5 & None & Solvent-free & 120 & 150 & 19 \\
\hline 6 & 0.06 & Solvent-free & 120 & 100 & 27 \\
\hline 7 & 0.08 & Solvent-free & 120 & 100 & 31 \\
\hline 8 & 0.08 & Solvent-free & 100 & 100 & 25 \\
\hline 9 & 0.02 & $\mathrm{H}_{2} \mathrm{O}$ & Reflux & 80 & 59 \\
\hline 10 & 0.04 & $\mathrm{H}_{2} \mathrm{O}$ & Reflux & 60 & 76 \\
\hline 11 & 0.06 & $\mathrm{H}_{2} \mathrm{O}$ & Reflux & 40 & 88 \\
\hline 12 & 0.08 & $\mathrm{H}_{2} \mathrm{O}$ & Reflux & 30 & 97 \\
\hline 13 & 0.08 & $\mathrm{H}_{2} \mathrm{O}$ & 80 & 50 & 90 \\
\hline 14 & 0.08 & $\mathrm{H}_{2} \mathrm{O}$ & r.t. & 40 & 82 \\
\hline 15 & 0.1 & $\mathrm{H}_{2} \mathrm{O}$ & Reflux & 30 & 96 \\
\hline 16 & 0.04 & $\mathrm{EtOH}$ & Reflux & 70 & 58 \\
\hline 17 & 0.06 & $\mathrm{EtOH}$ & Reflux & 50 & 71 \\
\hline 18 & 0.08 & $\mathrm{EtOH}$ & Reflux & 45 & 86 \\
\hline 19 & 0.08 & $\mathrm{EtOH}$ & r.t. & 50 & 75 \\
\hline 20 & 0.06 & $\mathrm{MeOH}$ & Reflux & 60 & 63 \\
\hline 21 & 0.08 & $\mathrm{MeOH}$ & Reflux & 55 & 81 \\
\hline 22 & 0.08 & $\mathrm{MeOH}$ & r.t. & 60 & 74 \\
\hline 24 & 0.06 & $\mathrm{CH}_{3} \mathrm{CN}$ & Reflux & 70 & 48 \\
\hline 25 & 0.08 & $\mathrm{CH}_{3} \mathrm{CN}$ & Reflux & 65 & 78 \\
\hline 25 & 0.08 & $\mathrm{CH}_{3} \mathrm{CN}$ & r.t. & 70 & 67 \\
\hline 26 & 0.06 & $\mathrm{CH}_{2} \mathrm{Cl}_{2}$ & Reflux & 70 & 45 \\
\hline 27 & 0.08 & $\mathrm{CH}_{2} \mathrm{Cl}_{2}$ & Reflux & 60 & 57 \\
\hline 28 & 0.08 & $\mathrm{CH}_{2} \mathrm{Cl}_{2}$ & r.t. & 80 & 49 \\
\hline
\end{tabular}

* Reaction conditions: Ethyl 7-chloro-6-fluoroquinolone-3-carboxylic acids 1a (1 mmol) and $N$-ethylpiperazine $2 \mathbf{y}(1.5 \mathrm{mmol})$. 
Yahya Mirzaie et al.

refluxing water. The $\left\{\mathrm{Mo}_{132}\right\}$ efficiently catalyzed the reactions, giving the desired products in high yields over relatively short reaction times. Easy separation of obtained products from the catalyst makes this method useful for the synthesis of fluoroquinolones. Purity checks with melting points, TLC, HPLC $(>92 \%)$, and the ${ }^{1} \mathrm{H}$ NMR spectroscopic data reveal that only one product is formed in all cases and no undesirable side-products are observed. The structures of all known products $\mathbf{3}$ were deduced and compared with those of authentic samples from their melting points, ${ }^{1} \mathrm{H}$ NMR, ${ }^{13} \mathrm{C}$ NMR, and FT-IR spectral data [18-29].

To test the recyclability of $\left\{\mathrm{Mo}_{132}\right\}$, after completion of the model reaction, the catalyst was recovered according to the procedure described in the experimental section. The separated catalyst was dried at $60^{\circ} \mathrm{C}$ under vacuum for $1 \mathrm{~h}$ before being reused in the same reaction. The catalyst could be used at least five times without significant reduction in its activity $(97,96$, $94,94,93 \%$ yields in first to fifth use, respectively) which clearly demonstrates the practical reusability of this catalyst.

Although we did not investigate the reaction mechanism, on the basis of our previous reports [38-40], it is reasonable to assume that several accessible Mo sites and $\mathrm{NH}_{4}$ groups in $\left\{\mathrm{Mo}_{132}\right\}$ could act as Lewis acid and Brönsted acid centers, respectively, and therefore promote the necessary reactions. The catalyst would play a significant role in increasing the electrophilic character of the electrophiles in the reaction.

\section{Conclusion}

In conclusion, in this paper we developed the synthesis of fluoroquinolone derivatives $\mathbf{3 a w}, \mathbf{3 a x}, \mathbf{3 a z}, \mathbf{3 b z}, \mathbf{3 c w}, \mathbf{3 c x}, \mathbf{3 d w}$, $\mathbf{3 d x}, \mathbf{3 d y}$, and $\mathbf{3 d z}$ in the presence of $\left\{\mathrm{Mo}_{132}\right\}$, a Keplerate-type giant-ball nanoporous isopolyoxomolybdate, as a highly effective heterogeneous catalyst for the direct amination of 7-halo-6-fluoroquinolone-3-carboxylic acids 1a-d with several amines $\mathbf{2} \mathbf{w}-\mathbf{z}$ in refluxing water. This method provided these products in high yields over short reaction time, following a facile work-up process. The catalyst is inexpensive and easily obtained, stable and storable, easily recycled and reused for several cycles with consistent activity.

\section{Experimental}

\section{Chemicals and apparatus}

All chemicals were available commercially and used without additional purification. The catalyst was synthesized according to the literature [32]. Melting points were recorded using a Stuart SMP3 melting point apparatus. The FT-IR spectra of the products were obtained with $\mathrm{KBr}$ disks, using a Tensor 27 Bruker spectrophotometer. The ${ }^{1} \mathrm{H}$ NMR (300 MHZ) and ${ }^{13} \mathrm{C}$ NMR (75 MHZ) spectra were recorded using Bruker spectrometers.

\section{Typical procedure}

A mixture of 7-chloro-1-cyclopropyl-6-fluoro-4-oxo-1,4-dihydroquinoline-3-carboxylic acid $\mathbf{1 a}(1 \mathrm{mmol})$ and $N$-ethylpiperazine $2 \mathbf{y}(1.5 \mathrm{mmol})$ and $\left\{\mathrm{Mo}_{132}\right\}(0.08 \mathrm{~g})$ as catalyst in $\mathrm{H}_{2} \mathrm{O}(5$ $\mathrm{ml}$ ) was heated under reflux for the appropriate time. The reaction was monitored by TLC. Since the catalyst solubility is very high in cold water, after completion of the transformation, the reaction mixture was allowed to cool down into room temperature. The crude product was collected by filtration, washed with $\mathrm{H}_{2} \mathrm{O}$ and recrystallized from ethanol to give desired compounds 3ay. The catalyst could be readily recovered from the combined filtrate after evaporation to dryness under reduced pressure and washing with hot ethanol.

1-Cyclopropyl-6-fluoro-4-oxo-7-(piperazin-1-yl)-1,4-dihydroquinoline-3-carboxylic acid (3aw)

HPLC Purity: $99.14 \%$; Yield: $92 \%$; 20 min; m.p: $254-256{ }^{\circ} \mathrm{C}$ (lit. [23] 255-257 ${ }^{\circ} \mathrm{C}$ ); FT-IR ( $v \mathrm{~cm}^{-1} \mathrm{KBr}$ disc): 3533,3335 , 3033, 2912, 1705, 1623, 1494, 1447, 1383, 1271, 1144, 1024, 804; ${ }^{1} \mathrm{H}$ NMR (300 MHz, DMSO-d $\left.{ }_{6}\right): \delta 1.15-1.20(\mathrm{~m}, 2 \mathrm{H}$, $\left.\mathrm{CH}_{2}\right), 1.30-1.35\left(\mathrm{~m}, 2 \mathrm{H}, \mathrm{CH}_{2}\right), 2.90\left(\mathrm{t}, J=6.0 \mathrm{~Hz}, 4 \mathrm{H}, 2 \mathrm{CH}_{2}\right.$ ), $3.22\left(\mathrm{t}, J=6.0 \mathrm{~Hz}, 4 \mathrm{H}, 2 \mathrm{CH}_{2}\right), 3.75-3.85(\mathrm{~m}, 1 \mathrm{H}, \mathrm{CH}), 7.47(\mathrm{~d}$, $J=9.0 \mathrm{~Hz}, 1 \mathrm{H}, \mathrm{C} 8 \mathrm{H}), 7.75(\mathrm{~d}, J=15.0 \mathrm{~Hz}, 1 \mathrm{H}, \mathrm{C} 5 \mathrm{H}), 8.58$ (s, $1 \mathrm{H}, \mathrm{C} 2 \mathrm{H}) ;{ }^{13} \mathrm{C}$ NMR (75 MHz, DMSO-d 6 ): $7.9\left(\mathrm{CH}_{2}\right), 36.2$ $(\mathrm{NCH}), 45.8\left(2 \mathrm{NCH}_{2}\right), 51.1\left(2 \mathrm{NCH}_{2}\right), 106.9(\mathrm{C} 3), 107.1(\mathrm{C} 8)$, 111.4 (C5), 118.7 (C4a), 139.6 (C8a), 146.1 (C7), 148.2 (C2), 154.0 (C6), 165.6 (COOH), 176.6 (C4); Anal. Calc. for $\mathrm{C}_{17} \mathrm{H}-$ ${ }_{18} \mathrm{FN}_{3} \mathrm{O}_{3}(\%)$ : C, 61.62; H, 5.48; N, 12.68. Found: C, 61.54; H, $5.37 ; \mathrm{N}, 12.62$.

1-Cyclopropyl-6-fluoro-7-(4-methylpiperazin-1-yl)-4-oxo-1, 4-dihydroquinoline-3-carboxylic acid (3ax)

HPLC Purity: 97.92\%; Yield: 96\%; 25 min; m.p: $245-247{ }^{\circ} \mathrm{C}$ (lit. [22] 248-250 ${ }^{\circ} \mathrm{C}$ ); FT-IR ( $v \mathrm{~cm}^{-1} \mathrm{KBr}$ disc): 3428,3093 , $2935,1729,1626,1507,1469,1378,1299,1142,1007,885 ;{ }^{1} \mathrm{H}$ NMR (300 MHz, DMSO-d $)$ ): $\delta 1.17\left(\mathrm{~s}, 2 \mathrm{H}, \mathrm{CH}_{2}\right), 1.32(\mathrm{~d}, J=$ $\left.9.0 \mathrm{~Hz}, 2 \mathrm{H}, \mathrm{CH}_{2}\right), 2.23\left(\mathrm{~s}, 3 \mathrm{H}, \mathrm{NCH}_{3}\right), 2.20-2.35(\mathrm{~m}, 4 \mathrm{H}$, $\left.2 \mathrm{CH}_{2}\right), 3.00-3.10\left(\mathrm{~m}, 4 \mathrm{H}, 2 \mathrm{CH}_{2}\right), 3.75-3.85(\mathrm{~m}, 1 \mathrm{H}, \mathrm{CH}), 7.47$ $(\mathrm{d}, J=6.0 \mathrm{~Hz}, 1 \mathrm{H}, \mathrm{C} 8 \mathrm{H}), 7.75(\mathrm{~d}, J=12.0 \mathrm{~Hz}, 1 \mathrm{H}, \mathrm{C} 5 \mathrm{H}), 8.62$ (s, $1 \mathrm{H}, \mathrm{C} 2 \mathrm{H}) ;{ }^{13} \mathrm{C}$ NMR (75 MHz, DMSO-d 6 ): $8.0\left(2 \mathrm{CH}_{2}\right), 31.2$ $\left(\mathrm{NCH}_{3}\right), 36.3(\mathrm{NCH}), 45.9\left(2 \mathrm{NCH}_{2}\right), 49.4\left(2 \mathrm{NCH}_{2}\right), 106.0$ (C3), 107.1 (C8), 111.0 (C5), 118.0 (C4a), 139.6 (C8a), 146.1 (C7), 148.3 (C2), 151.0 (C6), 166.3 (COOH), 176.7 (C4); Anal. Calc. for $\mathrm{C}_{18} \mathrm{H}_{20} \mathrm{FN}_{3} \mathrm{O}_{3}(\%)$ : C, 62.60; H, 5.84; N, 12.17; Found: C, 62.53; H, 5.78; N, 12.11 .

1-Cyclopropyl-7-(4-ethylpiperazin-1-yl)-6-fluoro-4-oxo-1, 4-dihydroquinoline-3-carboxylic acid (3ay)

HPLC Purity: $99.06 \%$; Yield: 97\%; 30 min; m.p: $218-220{ }^{\circ} \mathrm{C}$ (lit. [22] 219-221 ${ }^{\circ} \mathrm{C}$ ); FT-IR ( $v \mathrm{~cm}^{-1} \mathrm{KBr}$ disc): 3533, 3335, 3033, 2912, 1738, 1627, 1470, 1381, 1337, 1254, 1154, 1022, 803; ${ }^{1} \mathrm{H}$ NMR (300 MHz, DMSO-d $\left.{ }_{6}\right): \delta 1.05(\mathrm{t}, J=7.0 \mathrm{~Hz}, 3 \mathrm{H}$, $\left.\mathrm{CH}_{3}\right), 1.10-1.35\left(\mathrm{~m}, 4 \mathrm{H}, 2 \mathrm{CH}_{2}\right), 2.42$ (q, $J=6.0 \mathrm{~Hz}, 2 \mathrm{H}, \mathrm{NCH}_{2}$ ), 2.50-2.60 (m, $8 \mathrm{H}, 4 \mathrm{CH}_{2}$, overlapped with solvent), 3.75-3.85 (m, 1H, CH), $7.55(\mathrm{~d}, J=6.0 \mathrm{~Hz}, 1 \mathrm{H}, \mathrm{C} 8 \mathrm{H}), 7.88(\mathrm{~d}, J=15.0$ 
$\mathrm{Hz}, 1 \mathrm{H}, \mathrm{C} 5 \mathrm{H}), 8.65$ (s, $1 \mathrm{H}, \mathrm{C} 2 \mathrm{H}), 15.23$ (s br., $1 \mathrm{H}, \mathrm{COOH}) ;{ }^{13} \mathrm{C}$ NMR (75 MHz, DMSO-d $\left.{ }_{6}\right): 8.0\left(2 \mathrm{CH}_{2}\right), 12.4\left(\mathrm{CH}_{3}\right), 36.2$ $(\mathrm{NCH}), 40.7\left(\mathrm{NCH}_{2}\right), 49.8-52.4\left(4 \mathrm{NCH}_{2}\right), 106.5(\mathrm{C} 3), 107.1$ (C8), 111.3 (C5), 118.8 (C4a), 139.5 (C8a), 145.5 (C7), 148.1 (C2), 155.0 (C6), 166.3 (COOH), 176.5 (C4); Anal. Calc. for $\mathrm{C}_{19} \mathrm{H}_{22} \mathrm{FN}_{3} \mathrm{O}_{3}$ (\%): C, 63.50; H, 6.17; N, 11.69; Found: C, $63.41 ; \mathrm{H}, 6.09 ; \mathrm{N}, 11.62$.

1-Cyclopropyl-6-fluoro-7-((4aR,7aR)-hexahydro-1H-pyrrolo [3,4-b]pyridin-6(2H)-yl)-4-oxo-1,4-dihydroquinoline-3-carboxylic acid (3az)

HPLC Purity: $92.96 \%$; Yield: $91 \%$; 18 min; m.p: $258-260{ }^{\circ} \mathrm{C}$ (lit. [24] 256-258 ${ }^{\circ} \mathrm{C}$ ); FT-IR ( $v \mathrm{~cm}^{-1} \mathrm{KBr}$ disc): 3504,3308 , 3076, 2938, 1719, 1629, 1549, 1509, 1412, 1336, 1180, 1108, $888 ;{ }^{1} \mathrm{H}$ NMR $\left(300 \mathrm{MHz}, \mathrm{DMSO}_{\mathrm{d}}\right.$ ): $\delta 1.10-1.35(\mathrm{~m}, 4 \mathrm{H}$, $\left.2 \mathrm{CH}_{2}\right), 1.55-1.70\left(\mathrm{~m}, 4 \mathrm{H}, 2 \mathrm{CH}_{2}\right), 2.50-2.60(\mathrm{~m}, 1 \mathrm{H}, \mathrm{CH}), 3.33$ (t, $\left.J=6.0 \mathrm{~Hz}, 2 \mathrm{H}, \mathrm{CH}_{2}\right), 3.30-3.55\left(\mathrm{~m}, 4 \mathrm{H}, 2 \mathrm{CH}_{2}\right), 3.63-3.75$ (m, H, CH), 6.91 (d, $J=6.0 \mathrm{~Hz}, 1 \mathrm{H}, \mathrm{C} 8 \mathrm{H}), 7.65(\mathrm{~d}, J=15.0 \mathrm{~Hz}$, $1 \mathrm{H}, \mathrm{C} 5 \mathrm{H}), 8.49(\mathrm{~s}, 1 \mathrm{H}, \mathrm{C} 2 \mathrm{H})$; Anal. Calc. for $\mathrm{C}_{20} \mathrm{H}_{22} \mathrm{FN}_{3} \mathrm{O}_{3}(\%)$ : C, 64.68; H, 5.97; N, 11.31; Found: C, 64.61; H, 5.59; N, 11.25.

1-Cyclopropyl-6-fluoro-7-((4aR,7aR)-hexahydro-1H-pyrrolo[3,4-b]pyridin-6(2H)-yl)-8-methoxy-4-oxo-1,4-dihydroquinoline-3-carboxylic acid (3bz)

HPLC Purity: $96.58 \%$; Yield: $89 \%$; 30 min, m.p: $239-241{ }^{\circ} \mathrm{C}$ (lit. [29] 238-242 ${ }^{\circ} \mathrm{C}$ ); FT-IR ( $v \mathrm{~cm}^{-1} \mathrm{KBr}$ disc): 3529,3470 , 3033, 2929, 1708, 1624, 1517, 1457, 1353, 1324, 1186, 1047, $805 ;{ }^{1} \mathrm{H}$ NMR $\left(300 \mathrm{MHz}\right.$, DMSO-d $\left.{ }_{6}\right): \delta 0.81-1.25(\mathrm{~m}, 4 \mathrm{H}$, $\left.2 \mathrm{CH}_{2}\right), 1.63-1.85\left(\mathrm{~m}, 4 \mathrm{H}, 2 \mathrm{CH}_{2}\right), 2.60-2.70\left(\mathrm{~m}, 2 \mathrm{H}, \mathrm{CH}_{2}\right)$, 3.10-3.20 (m, 1H, CH), $3.37\left(\mathrm{~s}, 3 \mathrm{H}, \mathrm{OCH}_{3}\right), 3.60-3.65(\mathrm{~m}, 1 \mathrm{H}$, $\mathrm{CH}), 3.70-3.80(\mathrm{~m}, 1 \mathrm{H}, \mathrm{CH}), 3.80-3.97\left(\mathrm{~m}, 2 \mathrm{H}, \mathrm{CH}_{2}\right), 4.04-$ $4.19\left(\mathrm{~m}, 2 \mathrm{H}, \mathrm{CH}_{2}\right), 7.63(\mathrm{dd}, J=12.0,3.0 \mathrm{~Hz}, 1 \mathrm{H}, \mathrm{C} 5 \mathrm{H}), 8.64$ (s, $1 \mathrm{H}, \mathrm{C} 2 \mathrm{H}), 15.15$ (s br., $\mathrm{COOH}) ;{ }^{13} \mathrm{C}$ NMR $(75 \mathrm{MHz}, \mathrm{DM}-$ SO-d $\left.{ }_{6}\right): 8.8\left(2 \mathrm{CH}_{2}\right) 10.0\left(\mathrm{CH}_{2}\right), 17.2\left(\mathrm{CH}_{2}\right), 20.9(\mathrm{CH}), 34.6$ $\left(\mathrm{NCH}_{2}\right), 39.1(\mathrm{NCH}), 41.1\left(\mathrm{NCH}_{2}\right), 41.8(\mathrm{NCH}), 54.4\left(\mathrm{NCH}_{2}\right)$, $62.3\left(\mathrm{OCH}_{3}\right), 106.8(\mathrm{C} 3), 117.6(\mathrm{C} 5), 134.9(\mathrm{C} 4 \mathrm{a}), 137.1(\mathrm{C} 8)$, 140.6 (C8a), 150.8 (C7), 151.7 (C2), 154.0 (C6), 166.3 $(\mathrm{COOH}), 176.4$ (C4); Anal. Calc. for $\mathrm{C}_{21} \mathrm{H}_{24} \mathrm{FN}_{3} \mathrm{O}_{4}$ (\%): C, $62.83 ;$ H, 6.03; N, 10.47; Found: C, 62.78; H, 5.94; N, 10.41.

9-Fluoro-3-methyl-7-oxo-10-(piperazin-1-yl)-3,7-dihydro2H-[1,4]oxazino[2,3,4-ij]quinoline-6-carboxylic acid (3cw) HPLC Purity: 95.19\%; Yield: 91\%; 27 min; m.p: $258-260{ }^{\circ} \mathrm{C}$ (lit. [27] 257-260 ${ }^{\circ} \mathrm{C}$ ); FT-IR ( $v \mathrm{~cm}^{-1} \mathrm{KBr}$ disc): 3255,3092 , $2968,1723,1573,1454,1392,1254,1023,1011,805 ;{ }^{1} \mathrm{H}$ NMR $\left(300 \mathrm{MHz}, \mathrm{DMSO}-\mathrm{d}_{6}\right): \delta 1.44\left(\mathrm{~d}, J=6.0 \mathrm{~Hz}, 3 \mathrm{H}, \mathrm{CH}_{3}\right), 2.80-$ $2.85\left(\mathrm{~m}, 4 \mathrm{H}, 2 \mathrm{CH}_{2}\right), 3.18-3.25\left(\mathrm{~m}, 4 \mathrm{H}, 2 \mathrm{CH}_{2}\right.$, overlapped with solvent), 4.37 (d, $J=12.0 \mathrm{~Hz}, 1 \mathrm{H}, \mathrm{CH}_{2}$ diastereotopic proton), 4.58 (d, $J=12.0 \mathrm{~Hz}, 1 \mathrm{H}, \mathrm{CH}_{2}$, diastereotopic proton), 4.85-4.95 (m, $1 \mathrm{H}, \mathrm{CH}), 7.51(\mathrm{dd}, J=12.0,6.0 \mathrm{~Hz}, 1 \mathrm{H}, \mathrm{C} 5 \mathrm{H}), 8.91(\mathrm{~s}, 1 \mathrm{H}$, $\mathrm{C} 2 \mathrm{H}) ;{ }^{13} \mathrm{C}$ NMR $\left(75 \mathrm{MHz}\right.$, DMSO-d 6 ): $18.4\left(\mathrm{CH}_{3}\right), 46.6$ $\left(2 \mathrm{NCH}_{2}\right), 52.0\left(2 \mathrm{NCH}_{2}\right), 55.2(\mathrm{NCH}), 68.4\left(\mathrm{OCH}_{2}\right), 103.6$ (C5), 107.1 (C3), 120.0 (C4a), 125.2 (C8a), 132.3 (C7), 140.5 (C8), 146.5 (C2), 154.0 (C6), 166.5 (COOH), 176.7 (C4); Anal. Calc. for $\mathrm{C}_{17} \mathrm{H}_{18} \mathrm{FN}_{3} \mathrm{O}_{4}(\%)$ : C, 58.78; H, 5.22; N, 12.10; Found: C, 58.72; H, 5.17; N, 10.36 .
9-Fluoro-3-methyl-10-(4-methylpiperazin-1-yl)-7-oxo-3,7-dihydro-2H-[1,4] oxazino[2,3,4-ij]quinoline-6-carboxylic acid (3cx) HPLC Purity: $99.89 \%$; Yield: $89 \%$; 20 min; m.p: $253-255^{\circ} \mathrm{C}$ (lit. [27] 250-257 ${ }^{\circ} \mathrm{C}$ ); FT-IR ( $v \mathrm{~cm}^{-1} \mathrm{KBr}$ disc): 3419,3335 , 3043, 2968, 1714, 1622, 1523, 1469, 1371, 1255, 1146, 1056, 804; ${ }^{1} \mathrm{H}$ NMR (300 MHz, DMSO-d 6 ): $\delta 1.44(\mathrm{~d}, J=9.0 \mathrm{~Hz}, 3 \mathrm{H}$, $\left.\mathrm{CH}_{3}\right), 2.22\left(\mathrm{~s}, 3 \mathrm{H}, \mathrm{NCH}_{3}\right), 2.35-2.50\left(\mathrm{~m}, 4 \mathrm{H}, 2 \mathrm{CH}_{2}\right), 3.20-3.40$ $\left(\mathrm{m}, 4 \mathrm{H}, 2 \mathrm{CH}_{2}\right), 4.35$ (dd, $J=12.0,3.0 \mathrm{~Hz}, 1 \mathrm{H}, \mathrm{CH}_{2}$, diastereotopic proton), $4.59\left(\mathrm{dd}, J=12.0,3.0,1 \mathrm{H}, \mathrm{CH}_{2}\right.$, diastereotopic proton), 4.85-4.98 (m, 1H, CH), $7.52(\mathrm{~d}, J=12.0 \mathrm{~Hz}, 1 \mathrm{H}, \mathrm{C} 5 \mathrm{H})$, 8.95 (s, 1H, C2H), 15.17 (s br., $1 \mathrm{H}, \mathrm{COOH}) ;{ }^{13} \mathrm{C}$ NMR $(75$ $\left.\mathrm{MHz}, \mathrm{DMSO}-\mathrm{d}_{6}\right): 18.4\left(\mathrm{CH}_{3}\right), 46.5\left(\mathrm{NCH}_{3}\right), 50.5\left(2 \mathrm{NCH}_{2}\right)$, $55.2\left(2 \mathrm{NCH}_{2}\right), 55.7(\mathrm{NCH}), 68.4\left(\mathrm{OCH}_{2}\right), 103.5(\mathrm{C} 5), 107.0$ (C3), 119.8 (C4a), 125.2 (C8a), 132.5 (C7), 140.5 (C8), 146.5 (C2), 154.2 (C6), 166.5 (COOH), 176.7 (C4); Anal. Calc. for $\mathrm{C}_{18} \mathrm{H}_{20} \mathrm{FN}_{3} \mathrm{O}_{4}$ (\%): C, 59.83; H, 5.58; N, 11.63; Found: C, 59.77; H, 5.08; N, 11.58 .

(S)-9-Fluoro-3-methyl-7-oxo-10-(piperazin-1-yl)-3,7-dihydro2H-[1,4]oxazino[2,3,4-ij]quinoline-6-carboxylic acid (3dw) HPLC Purity: $99.65 \%$; Yield: $95 \%$; 32 min; m.p: $260-262{ }^{\circ} \mathrm{C}$ (lit. [29] 263-265 ${ }^{\circ} \mathrm{C}$ ); FT-IR ( $v \mathrm{~cm}^{-1} \mathrm{KBr}$ disc): 3255, 3092, $2968,1723,1573,1454,1392,1254,1023,1011,805 ;{ }^{1} \mathrm{H}$ NMR (300 MHz, DMSO-d 6 ): $\delta 1.45$ (d, $J=6.0 \mathrm{~Hz}, 3 \mathrm{H}, \mathrm{CH}_{3}$ ), $2.75-$ $2.85\left(\mathrm{~m}, 4 \mathrm{H}, 2 \mathrm{CH}_{2}\right), 3.15-3.25\left(\mathrm{~m}, 4 \mathrm{H}, 2 \mathrm{CH}_{2}\right.$, overlapped with solvent), 4.30-4.40 (m, $1 \mathrm{H}, \mathrm{CH}_{2}$, diastereotopic proton), 4.52$4.62\left(\mathrm{~m}, 1 \mathrm{H}, \mathrm{CH}_{2}\right.$, diastereotopic proton), 4.85-4.95 $(\mathrm{m}, 1 \mathrm{H}$, $\mathrm{CH}), 7.51(\mathrm{~d}, J=12.0 \mathrm{~Hz}, 1 \mathrm{H}, \mathrm{C} 5 \mathrm{H}), 8.92(\mathrm{~s}, 1 \mathrm{H}, \mathrm{C} 2 \mathrm{H}) ;{ }^{13} \mathrm{C}$ NMR (75 MHz, DMSO-d $\left.{ }_{6}\right): 18.4\left(\mathrm{CH}_{3}\right), 45.8\left(2 \mathrm{NCH}_{2}\right), 51.0$ $\left(2 \mathrm{NCH}_{2}\right), 55.2(\mathrm{NCH}), 68.5\left(\mathrm{OCH}_{2}\right), 103.6(\mathrm{C} 5), 107.2(\mathrm{C} 3)$, 120.2 (C4a), 125.2 (C8a), 132.3 (C7), 140.5 (C8), 146.5 (C2), 154.2 (C6), $166.5(\mathrm{COOH}), 176.7$ (C4); Anal. Calc. for $\mathrm{C}_{17} \mathrm{H}-$ ${ }_{18} \mathrm{FN}_{3} \mathrm{O}_{4}(\%): \mathrm{C}, 58.78 ; \mathrm{H}, 5.22 ; \mathrm{N}, 12.10$; Found: C, 58.70; H, 4.93; N, 11.51 .

(S)-9-Fluoro-3-methyl-10-(4-methylpiperazin-1-yl)-7-oxo-3,7-dihydro-2H-[1,4]oxazino [2,3,4-ij]quinoline-6-carboxylic acid (3dx) HPLC Purity: $100 \%$; Yield: $93 \%$; 22 min; m.p: $225-227^{\circ} \mathrm{C}$ (lit. [25] 225-226 $\left.{ }^{\circ} \mathrm{C}\right)$; FT-IR ( $v \mathrm{~cm}^{-1} \mathrm{KBr}$ disc): $3251,3079,2973$, 1721, 1539, 1517, 1439, 1394, 1289, 1087, 1004, 801; ${ }^{1}$ H NMR $\left(300 \mathrm{MHz}, \mathrm{DMSO}-\mathrm{d}_{6}\right): \delta 1.44\left(\mathrm{~d}, J=6.0 \mathrm{~Hz}, 3 \mathrm{H}, \mathrm{CH}_{3}\right), 2.22(\mathrm{~s}$, $\left.3 \mathrm{H}, \mathrm{NCH}_{3}\right), 2.35-2.50\left(\mathrm{~m}, 4 \mathrm{H}, 2 \mathrm{CH}_{2}\right), 3.20-3.30\left(\mathrm{~m}, 4 \mathrm{H}, 2 \mathrm{CH}_{2}\right.$ ), 4.36 (dd, $J=12.0,3.0 \mathrm{~Hz}, 1 \mathrm{H}, \mathrm{CH}_{2}$, diastereotopic proton), 4.59 (dd, $J=12.0,3.0 \mathrm{~Hz}, 1 \mathrm{H}, \mathrm{CH}_{2}$, diastereotopic proton), $4.85-$ $4.95(\mathrm{~m}, 1 \mathrm{H}, \mathrm{CH}), 7.48(\mathrm{~d}, J=12.0 \mathrm{~Hz}, 1 \mathrm{H}, \mathrm{C} 5 \mathrm{H}), 8.94(\mathrm{~s}, 1 \mathrm{H}$, $\mathrm{C} 2 \mathrm{H}$ ), 15.15 (s br., $1 \mathrm{H}, \mathrm{COOH}$ ); ${ }^{13} \mathrm{C}$ NMR $(75 \mathrm{MHz}, \mathrm{DM}-$ $\left.\mathrm{SO}-\mathrm{d}_{6}\right): 18.4\left(\mathrm{CH}_{3}\right), 46.5\left(\mathrm{NCH}_{3}\right), 50.5\left(2 \mathrm{NCH}_{2}\right), 55.2\left(2 \mathrm{NCH}_{2}\right)$, $55.7(\mathrm{NCH}), 68.4\left(\mathrm{OCH}_{2}\right), 103.8(\mathrm{C} 5), 107(\mathrm{C} 3), 120(\mathrm{C} 4 \mathrm{a})$, 125.2 (C8a), 132.3 (C7), 140.4 (C8), 146.5 (C2), 154.2 (C6), $166.5(\mathrm{COOH}), 176.7$ (C4); Anal. Calc. for $\mathrm{C}_{18} \mathrm{H}_{20} \mathrm{FN}_{3} \mathrm{O}_{4}(\%)$ : C, 59.83; H, 5.58; N, 11.63; Found: C, 59.78; H, 5.50; N, 11.56 .

(S)-10-(4-Ethylpiperazin-1-yl)-9-fluoro-3-methyl-7-oxo-3,7-dihydro-2H-[1,4] oxazino[2,3,4-ij]quinoline-6-carboxylic acid (3dy) HPLC Purity: $99.26 \%$; Yield: 88\%; 20 min; m.p: $230-232{ }^{\circ} \mathrm{C}$ (lit. [26] 229-230 ${ }^{\circ} \mathrm{C}$ ); FT-IR ( $v \mathrm{~cm}^{-1} \mathrm{KBr}$ disc): 3432, 3042, 
$2975,1714,1623,1529,1478,1306,1243,1200,1010,743 ;{ }^{1} \mathrm{H}$ NMR (300 MHz, DMSO-d $\left.{ }_{6}\right): \delta 1.05\left(\mathrm{t}, J=6.0 \mathrm{~Hz}, 3 \mathrm{H}, \mathrm{CH}_{3}\right)$, 1.45 (d, $\left.J=9.0 \mathrm{~Hz}, 3 \mathrm{H}, \mathrm{CH}_{3}\right), 2.35-2.40$ (m, $2 \mathrm{H}, \mathrm{CH}_{2}$, overlapped with solvent) $2.40-2.60\left(\mathrm{~m}, 4 \mathrm{H}, 2 \mathrm{CH}_{2}\right), 3.15-3.20(\mathrm{~m}$, $\left.4 \mathrm{H}, 2 \mathrm{CH}_{2}\right), 4.37\left(\mathrm{~d}, J=12.0 \mathrm{~Hz}, 1 \mathrm{H}, \mathrm{CH}_{2}\right.$, diastereotopic proton), 4.57 (d, $J=9.0 \mathrm{~Hz}, 1 \mathrm{H}, \mathrm{CH}_{2}$, diastereotopic proton), 4.91 (d, $1 \mathrm{H}, J=6.0 \mathrm{~Hz}, \mathrm{CH}), 7.56$ (d, $J=12.0 \mathrm{~Hz}, 1 \mathrm{H}, \mathrm{C} 5 \mathrm{H}), 8.94$ (s, 1H, C2H); ${ }^{13} \mathrm{C}$ NMR (75 MHz, DMSO-d 6$)$ : $12.2\left(\mathrm{CH}_{3}\right), 18.4$ $\left(\mathrm{CH}_{3}\right), 46.5\left(\mathrm{NCH}_{2}\right), 50.5\left(2 \mathrm{NCH}_{2}\right), 53.4\left(2 \mathrm{NCH}_{2}\right), 55.3$ $(\mathrm{NCH}), 68.5\left(\mathrm{OCH}_{2}\right), 103.0(\mathrm{C} 5), 107.0(\mathrm{C} 3), 125.2(\mathrm{C} 4 \mathrm{a})$, 126.8 (C8a), 132.3 (C7), 140.0 (C8), 146.7 (C2), 154.0 (C6), $166.5(\mathrm{COOH}), 176.6(\mathrm{C} 4)$; Anal. Calc. for $\mathrm{C}_{19} \mathrm{H}_{22} \mathrm{FN}_{3} \mathrm{O}_{4}(\%)$ : C, 60.79; H, 5.91; N, 11.19; Found: C, 60.72; H, 5.84; N, 11.11.

(S)-9-Fluoro-10-((4aR,7aR)-hexahydro-1H-pyrrolo[3,4-b]pyridin-6(2H)-yl)-3-methyl-7-oxo-3,7-dihydro-2H-[1,4]oxazino[2,3,4-ij]quinoline-6-carboxylic acid (3dz)

HPLC Purity: 98.63\%; Yield: $94 \%$; 25 min; m.p: $265-267{ }^{\circ} \mathrm{C}$ (lit. [24] 265-268 $\left.{ }^{\circ} \mathrm{C}\right)$; FT-IR ( $v \mathrm{~cm}^{-1} \mathrm{KBr}$ disc): 3319,3044 , 2932, 1719, 1622, 1527, 1472, 1357, 1191, 1087, 1045, 862; ${ }^{1} \mathrm{H}$ NMR (300 MHz, DMSO-d $\left.\mathrm{d}_{6}\right): \delta 1.30-1.70\left(\mathrm{~m}, 4 \mathrm{H}, 2 \mathrm{CH}_{2}\right), 1.45$ $\left(\mathrm{d}, J=6.0 \mathrm{~Hz}, 3 \mathrm{H}, \mathrm{CH}_{3}\right), 2.10-2.20(\mathrm{~m}, 1 \mathrm{H}, \mathrm{CH}), 2.80-2.90(\mathrm{~m}$, $1 \mathrm{H}, \mathrm{CH}), 3.15-3.40\left(\mathrm{~m}, 4 \mathrm{H}, 2 \mathrm{CH}_{2}\right), 4.00-4.15\left(\mathrm{~m}, 2 \mathrm{H}, \mathrm{CH}_{2}\right)$, $4.23\left(\mathrm{~d}, J=12.0 \mathrm{~Hz}, 1 \mathrm{H}, \mathrm{CH}_{2}\right.$, diastereotopic proton), 4.59 (d, $J$ $=12.0 \mathrm{~Hz}, 1 \mathrm{H}, \mathrm{CH}_{2}$, diastereotopic proton), $4.80-4.92(\mathrm{~m}, 1 \mathrm{H}$, $\mathrm{CH}), 7.47(\mathrm{~d}, J=15 \mathrm{~Hz}, 1 \mathrm{H}, \mathrm{C} 5 \mathrm{H}), 8.85(\mathrm{~s}, 1 \mathrm{H}, \mathrm{C} 2 \mathrm{H})$; Anal. Calc. for $\mathrm{C}_{20} \mathrm{H}_{22} \mathrm{FN}_{3} \mathrm{O}_{4}(\%)$ : C, 62.01; H, 5.72; N, 10.85; Found: C, 61.96; H, 5.74; N, 10.78 .

\section{Acknowledgements}

We acknowledge the financial support from Payame noor University of Mashhad, Islamic Azad University, Mashhad Branch, and TEMAD Pharmaceutical Ingredients Company in Iran for their support.

\section{References}

1. Fernandes, P. B.; Shipkowitz, N.; Bower, R. R.; Jarvis, K. P.; Weisz, J.; Chu, D. T. J. Antimicrob. Chemother 1986, 18, 693-701.

2. Stein, G. E.; Goldstein, E. J. Clin. Infect. Dis. 2006, 42, 1598-1607.

3. Chen, Y. L.; Fang, K. C.; Sheu, J. Y.; Hsu, S. L.; Tzeng, C. C. J. Med. Chem. 2001, 44, 2374-2377.

4. Fujimaki, K.; Noumi, T.; Saikawa, I.; Inoue, M.; Mitsuhashi, S. Antimicrob. Agents Chemother. 1988, 32, 827-833.

5. Golet, E. M.; Strehler, A.; Alder, A. C.; Giger, W. Anal. Chem. 2002, 74, 5455-5462.

6. O'Donnell, J. A.; Gelone, S. P. Infect. Dis. Clin. North Am. 2000, 14, 489-513.

7. Zhanel, G. G.; Walkty, A.; Vercaigne, L.; Karlowsky, J. A.; Embil, J.; Gin, A. S.; Hoban, D. J. Can. J. Infect. Dis. Med. Microbiol. 1999, 10, 207-238.

8. Llorente, B.; Leclerc, F.; Cedergren, R. Bioorg. Med. Chem. 1996, 4, 61-71.
9. Wentland, M. P.; Lesher, G. Y.; Reuman, M.; Gruett, M. D.; Singh, B.; Aldous, S. C.; Dorff, P. H.; Rake, J. B.; Coughlin, S. A. J. Med. Chem. 1993, 36, 2801-2809.

10. Elsea, S. H.; Osheroff, N.; Nitiss, J. L. J. Biol. Chem. 1992, 267, 13150-13153.

11. Oh, Y. S.; Lee, C. W.; Chung, Y. H.; Yoon, S. J.; Cho, S. H. J. Heterocycl. Chem. 1998, 35, 541-550.

12. Karlowsky, J. A.; Adam, H. J.; Desjardins, M.; Lagacé-Wiens, P. R.; Hoban, D. J.; Zhanel, G. G.; Baxter, M. R.; Nichol, K. A.; Walkty, A.; Alliance, C. A. R. J. Antimicrob. Chemother. 2013, 68, i39-i46.

13. Gootz, T. D.; Brighty, K. E. Med. Res. Rev. 1996, 16, 433-486.

14. Aubry, A.; Pan, X. S.; Fisher, L. M.; Jarlier, V.; Cambau, E. Antimicrob. Agents Chemother. 2004, 48, 1281-1288.

15. Mitscher, L. A. Chem. Rev. 2005, 105, 559-592.

16. Sriram, D.; Aubry, A.; Yogeeswari, P.; Fisher, L. Bioorg. Med. Chem. Lett. 2006, 16, 2982-2985.

17. Dubar, F.; Anquetin, G.; Pradines, B.; Dive, D.; Khalife, J.; Biot, C. J. Med. Chem. 2009, 52, 7954-7957.

18. Shindikar, A. V.; Viswanathan, C. Bioorg. Med. Chem. Lett. 2005, 15, 1803-1806.

19. Reddy, P. G.; Baskaran, S. Tetrahedron Lett. 2001, 42, 6775-6777.

20. Kawakami, K.; Namba, K.; Tanaka, M.; Matsuhashi, N.; Sato, K.; Takemura, M. Antimicrob. Agents Chemother. 2000, 44, 2126-2129.

21. Schwarcz, R.; Kajii, Y.; Ono, S. I.; Ono S. I. U.S. Patent: 12/742171, 2008.

22. Grohe, K.; Heitzer, H. Liebigs Ann. Chem. 1987, 1987, 29-37.

23. Petersen, U.; Grohe, K.; Kuck, K. H. U.S. Patent: 4563459, 1986.

24. Petersen, U.; Schrock, W.; Habich, D.; Krebs, A.; Schenke, T.; Philipps, T.; Grohe, K.; Endermann, R.; Bremm, K. D.; Metzger, K. G. U.S. Patent: 5480879, 1996.

25. Lee, T. A. Khoo, J. H. Song S. H. Patent: WO2006009374, 2006.

26. Hayakawa, I.; Atarashi, S.; Imamura, M.; Yokohama, S.; Higashihashi, N.; Sakano, K.; Ohshima, M. U.S. Patent: 4985557, 1991.

27. Hayakawa, I.; Hiramitsu, T.; Tanaka, Y. Chem. Pharm. Bull. 1984, 32, 4907-4913.

28. Moxifloxacin. Tuberculosis, 2008, 88, 127-131.

29. Guruswamy, B.; Arul, R. Lett. Drug Des. Discov. 2013, 10, 86-93.

30. Müller, A.; Das, S. K.; Talismanov, S.; Roy, S.; Beckmann, E.; Bögge, H.; Schmidtmann, M.; Merca, A.; Berkle, A.; Allouche, L.; Zhou, Y. Angew. Chem. 2003, 115, 5193-5198.

31. Zhang, L.; Xiong, T.; Zhou, Y.; Zhang, L. Chem. Asian J. 2010, 5, 1984-1987.

32. Müller, A.; Krickemeyer, E.; Bögge, H.; Schmidtmann, M.; Peters, F. Angew. Chem. Int. Ed. 1998, 37, 3359-3363.

33. Polarz, S.; Smarsly, B.; Göltner, C.; Antonietti, M. Adv. Mater. 2000, 12, 1503-1507.

34. Greedan, J. E. J. Mater. Chem. 2001, 11, 37-53.

35. Kozhevnikov, I. V. Chem. Rev. 1998, 98, 171-198.

36. Kozhhevnikov, I. V. (Ed.), Catalysis for Fine Chemical Synthesis, Catalysis by Polyoxometalates 2, Wiley, New York, 2002.

37. Romanelli, G. P.; Bennardi, D.; Ruiz, D. M.; Baronetti, G.; Thomas, H. J.; Autino, J. C. Tetrahedron Lett. 2004, 45, 8935-8939.

38. Nakhaei, A.; Davoodnia, A. Chin. J. Catal. 2014, 35, 1761-1767.

39. Nakhaei, A.; Davoodnia, A.; Morsali, A. Res. Chem. Intermed. 2015, 41, 7815-7826.

40. Davoodnia, A.; Nakhaei, A. Synth. React. Inorg. M. 2016, 46, 1073-1080. 


\title{
Synthesis and Biological Evaluation of New 3,4-diarylmaleimides as Enhancers (modulators) of Doxorubicin Cytotoxic Activity on Cultured Tumor Cells from a Real Case of Breast Cancer
}

\author{
Jessica R. Gutierrez-Cano, Pradip D. Nahide, ${ }^{1 \&}$ Velayudham Ramadoss, ${ }^{1 \&}$ Yuvraj Satkar, ${ }^{1}$ \\ Rafael Ortiz-Alvarado, ${ }^{3}$ Clara Alba-Betancourt, ${ }^{2 *}$ Claudia L. Mendoza-Macías, ${ }^{2 *}$ and \\ César R. Solorio-Alvarado ${ }^{1 *}$ \\ 1 Departamento de Química, División de Ciencias Naturales y Exactas, Campus Guanajuato, Universidad de Guanajuato. \\ Cerro de la Venada S/N, 36040, Guanajuato, Gto., México. \\ 2 Departamento de Farmacia, División de Ciencias Naturales y Exactas, Campus Guanajuato, Universidad de Guanajuato. \\ Noria Alta S/N, 36050, Guanajuato, Gto., México. \\ 3 Facultad de Químico Farmacobiología, Universidad Michoacana de San Nicolás de Hidalgo, Tzintzuntzan 173, \\ Colonia Matamoros, 58240, Morelia, Michoacán, México. \\ \& These authors contribute equally to the paper. \\ *Correspondence: csolorio@ugto.mx; c.albabetancourt@ugto.mx; cl.mendoza@ugto.mx
}

Received August 1st, 2016; Accepted January 11th, 2017.

\begin{abstract}
A series of new 3,4-diarylmaleimides were synthesized in an optimized and efficient lineal sequence of three steps, starting from commercial maleimide. The biological evaluation of these compounds as enhancers (activity modulators) in the co-administration with doxorubicin treatment in breast cancer cells directly obtained from a patient, were essayed. The cancerous tissue BT026-512N was provided by the National Institute of Cancerology (INCAN) of México. This tissue was obtained by biopsy from a patient diagnosed with stage IIB ductal breast cancer. The results obtained in the assays, show decreased cell viability on the cultured cells for all of the maleimides synthesized in combinatorial administration with doxorubicin. The highest mortality effect was determined for maleimides 9 and 29 increased in close to three times the effect compared with treatment using only doxorubicin. Based on previous functionalized maleimides core reports and Molinspiration chemoinformatic analysis, these results could possibly point out to the Pg-p glycoprotein as bio-molecular action target of maleimides by kinase phosphorylation-inhibition, although more experimental data is necessary.
\end{abstract}

Keywords: Breast cancer, Maleimide; Doxorubicin; synergistic cancer treatment.

\section{Introduction}

Breast carcinoma is the most prevalent invasive malignancy among women worldwide, and constitutes one-third of all cancers and is the second cause of mortality only after lung cancer. Of all histological types of breast carcinomas, invasive ductal carcinoma (IDC), is the most prevalent type with an incidence of about $83 \%$. [1] Anthracyclines are among the most effective and commonly used chemotherapeutic drugs [2] and are the
Resumen: Una serie de nuevas 3,4-diarilmaleimidas fueron sintetizadas en una secuencia lineal optimizada y eficiente de tres pasos, iniciando de maleimida comercial. La evaluación biológica de estos compuestos como potenciadores (moduladores de actividad) en la coadministración con el tratamiento de doxorrubicina en un caso de células obtenidas de un paciente con cáncer de mama, fueron ensayados. El tejido canceroso BT026-512N fue provisto por el Instituto Nacional de Cancerología (INCAN) de México. Este tejido fue obtenido por biopsia de un paciente diagnosticado con cáncer de mama izquierdo con infiltración ductal en etapa IIB. Los resultados obtenidos en los ensayos muestran de manera general incremento en la mortalidad celular de los cultivos para todas las maleimidas sintetizadas en administración combinatoria con doxorrubicina. El efecto de mortalidad más alto fue determinado para las maleimidas 9 y 29 incrementando cerca de tres veces el efecto comparado con el tratamiento utilizando solamente doxorrubicina. Con base a reportes previos del núcleo funcional de las maleimidas así como un análisis quimioinformático en Molinspiration, estos resultados pudieran sugerir a la glicoproteína Pg-p como blanco biomolecular de acción de las maleimidas por la inhibición de la fosforilación de la cinasa, aunque más experimentos son necesarios para corroborarlos.

Palabras Clave: Cáncer de mama; maleimida; doxorrubicina; tratamiento sinérgico para cáncer.

most effective classes of cytotoxic agents for early stage breast cancer.

Anthracyclines are able to diffuse across the cell membrane, intercalate between DNA base pairs, generate free radicals (thus damaging DNA), target topoisomerase II (TOPOII), and induce cell apoptosis. [3]

The first generation of anthracyclines such as doxorubicin (Dox) and daunorubicin (Dnr), were isolated from Streptomyces peucetius, and display good activity against murine tumors 
[4-5]. Dox is an antibiotic with broad spectrum of antitumor activity in a variety of solid tumors including neuroblastoma, leukemia, Hodgkin's lymphoma, bladder and breast cancers, among others. However, it has a limited therapeutic index due to toxic side effects such as cardiotoxicity and high incidence of multiple drug resistance (MDR). [6-7]

The MDR mechanisms of anthracyclines are complicated and not fully understood. The most established mechanism of resistance is the over-expression of drug efflux proteins, particularly members of the ATP-binding cassette (ABC) superfamily: P-glycoprotein (P-gp), multidrug resistance protein 1 (MRP1), and breast cancer resistance protein (BCRP). Anthracyclines are known to be efficient substrates for $\mathrm{ABC}$ transporters. For example, P-gp, a membrane transporter encoded by MDR1 gene, pumps out a variety of hydrophobic anticancer drugs out of the cell, resulting in a decreased intracellular drug accumulation. [8-9] Therefore, the task of maintaining doxorubicin inside the tumor site, with high efficacy combined with low systemic exposure is a major challenge. Verapamil, a calcium channel blocker, was the first MDR reversal agent that was found to inhibit P-gp-mediated drug efflux. [10] Several compounds, containing a common 3,4-diaryl-substituted pyrrole nucleus bearing 2- or 2,5-carboxylates, can reverse MDR more effectively than verapamil by inhibiting the P-gp-mediated drug efflux at a noncytotoxic concentration. [11] Thus, in this work, new 3,4-diaryl maleimides were synthetized in order to improve doxorubicin cytotoxic activity, by modifying its substituents using the Suzuki-Miyaura cross-coupling reaction. These novel compounds and doxorubicin were assessed for their synergistic cytotoxic activity on cancer cells obtained from a breast cancer patient.

\section{Results}

\section{Organic Synthesis}

The synthesis of compounds 5-24 (table 2) was carried out by using Suzuki cross-coupling reaction among three
$\mathrm{N}$-alkyl-substituted 3,4-dibromomaleimide derivatives 2-4 and different aryl boronic acids. Thereby the synthetic protocol was developed in two lineal stages: 1) Synthesis of $N$-alkyl-3,4-dibromomaleimides and 2) The Suzuki cross-coupling to obtain the different drugs. The first stage is outlined in Scheme 1. Mild bromination of commercially available maleimide yields compound 1 in $92 \%$. The consecutive $N$-alkylation of 1 with $\mathrm{Me}_{2} \mathrm{SO}_{4}$, benzyl bromide and 3,4-dimethoxyphenethylbromide yield 2-4 respectively.

It is important to mention that compound $\mathbf{4}$ was obtained in very low yield, just enough for chemical characterization and it was not used in subsequent reactions.

The second stage consists on the Suzuki cross-coupling reaction. In order to get optimal yields for the different molecules to be synthesized, the organometallic procedure was optimized using $\mathbf{2}$ and phenylboronic acid as model system (Table 1).

Different palladium catalyst sources $\left(\mathrm{Pd}^{0}\right.$ and $\left.\mathrm{Pd}^{\mathrm{II}}\right)$ were tested in catalytic amount corresponding to 2, 4, 6 and $8 \mathrm{~mol} \%$. The reaction was carried out at room temperature and $90{ }^{\circ} \mathrm{C}$. On the other hand, sodium carbonate, cesium carbonate and tribasic potassium phosphate were tested as the bases. Also 1,4-dioxane, tetrahydrofuran (THF) and toluene:ethanol $(\mathrm{PhMe}: \mathrm{EtOH})(3: 1)$ were the solvents explored. Finally, the reactions were monitored from 3 to $24 \mathrm{~h}$ and the corresponding yields were determined by ${ }^{1} \mathrm{H}$ NMR spectroscopy using anisole as internal standard. In the first set of reactions, $\mathrm{Pd}\left(\mathrm{PPh}_{3}\right)_{4}$ and sodium bicarbonate in PhMe:EtOH (3:1) were tested during 3.5 to $6.5 \mathrm{~h}$ (entries 1-6). For this set of reactions, the use of $2 \mathrm{~mol} \%$ gives better yield at $90{ }^{\circ} \mathrm{C}$ than room temperature. Thus, $2 \%$ and $84 \%$ of yield were obtained (entries 1 and 4 ). The best yield of this set was obtained using $4 \mathrm{~mol} \%$ of catalyst at $90{ }^{\circ} \mathrm{C}(88 \%$, entry 5) while increasing the catalytic charge decreased the yield to $10 \%$ and $60 \%$ respectively (entries 3 and 6). Under the previously set assayed conditions taking $\mathrm{Pd}\left(\mathrm{PPh}_{3}\right)_{2} \mathrm{Cl}_{2}$ instead of palladium tetrakis, the yields decreased (entries 7-12). For the next group of reactions (entries 13-16) tribasic potassium phosphate and 1,4-dioxane was used keeping $\mathrm{Pd}\left(\mathrm{PPh}_{3}\right)_{2} \mathrm{Cl}_{2}$ as palladium catalyst in 4 and $8 \mathrm{~mol} \%$. The reactions at room

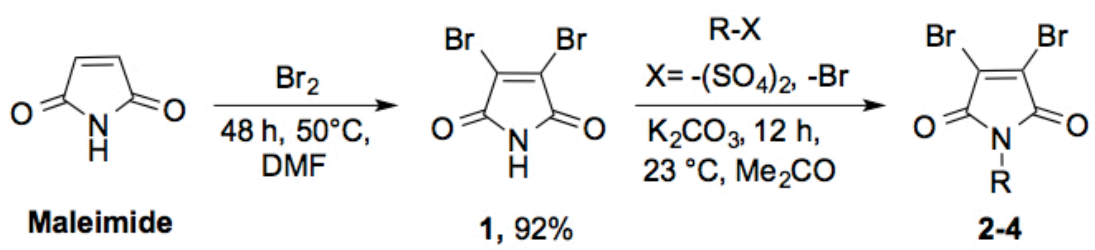

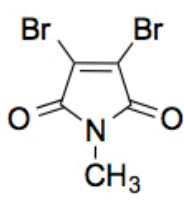

2, $75 \%$

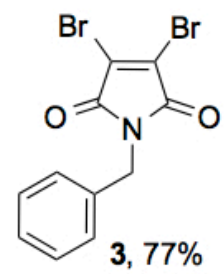

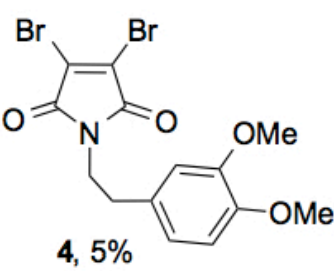

Scheme 1. Synthesis of the $N$-alkyl-substituted 3,4-dibromomaleimides 2-4. 
Table 1. Suzuki cross-coupling reaction optimization in the synthesis of 3,4-diphenyl- $N$-methylmaleimides.<smiles>CN1C(=O)C(Br)=C(Br)C1=O</smiles>

2<smiles>OB(O)c1ccccc1</smiles>
$\mathrm{Pd}^{(0)}$ or $\mathrm{Pd}^{(\mathrm{II})}$<smiles>CN1C(=O)C(c2ccccc2)=C(c2ccccc2)C1=O</smiles>

5

\begin{tabular}{|c|c|c|c|c|c|c|c|}
\hline Entry & $\mathrm{Pd}$ & $\mathrm{mol} \%$ & $\begin{array}{c}\text { Temperature } \\
\left({ }^{\circ} \mathrm{C}\right)\end{array}$ & Base & Solvent & $\begin{array}{l}\text { Time } \\
\text { (h) }\end{array}$ & $\begin{array}{c}\text { Yield }^{a} \\
(\%)\end{array}$ \\
\hline 1 & \multirow[t]{3}{*}{$\mathrm{Pd}\left(\mathrm{PPh}_{3}\right)_{4}$} & 2 & 23 & \multirow[t]{3}{*}{$\mathrm{Na}_{2} \mathrm{CO}_{3}$} & \multirow[t]{3}{*}{ PhMe:EtOH } & 6.5 & 2 \\
\hline 3 & & 8 & 23 & & & 6.5 & 10 \\
\hline 4 & & 2 & 90 & & & 3.5 & 84 \\
\hline 7 & \multirow[t]{4}{*}{$\mathrm{Pd}\left(\mathrm{PPh}_{3}\right)_{2} \mathrm{Cl}_{2}$} & 2 & 23 & \multirow[t]{4}{*}{$\mathrm{Na}_{2} \mathrm{CO}_{3}$} & \multirow[t]{4}{*}{ PhMe:EtOH } & 6 & 54 \\
\hline 8 & & 4 & 23 & & & 6 & 86 \\
\hline 9 & & 8 & 23 & & & 6 & 28 \\
\hline 10 & & 2 & 90 & & & 3 & 61 \\
\hline 14 & \multirow{3}{*}{$\mathrm{Pd}\left(\mathrm{PPh}_{3}\right)_{2} \mathrm{Cl}_{2}$} & 8 & 23 & \multirow{3}{*}{$\mathrm{K}_{3} \mathrm{PO}_{4}$} & \multirow{3}{*}{ 1,4-dioxano } & 24 & 33 \\
\hline 15 & & 4 & 90 & & & 3.5 & 88 \\
\hline 16 & & 8 & 90 & & & 3 & 65 \\
\hline 17 & \multirow[t]{4}{*}{$\mathrm{Pd}\left(\mathrm{PPh}_{3}\right)_{2} \mathrm{Cl}_{2}$} & 4 & 23 & \multirow[t]{4}{*}{$\mathrm{Cs}_{2} \mathrm{CO}_{3}$} & \multirow[t]{4}{*}{ THF } & 20 & 44 \\
\hline 18 & & 8 & 23 & & & 20 & 41 \\
\hline 19 & & 4 & 90 & & & 3 & 48 \\
\hline 20 & & 8 & 90 & & & 3 & 18 \\
\hline
\end{tabular}

${ }^{a}$ Chemical yields were determined by ${ }^{1} \mathrm{H}$ NMR using anisole as internal standard.

temperature gave low yields ( $21 \%$ and $33 \%$ respectively, entries 13 and 14). On the other hand, by increasing the temperature to $90^{\circ} \mathrm{C}$ we found the best results for our optimization. The reaction proceeded in only $3.5 \mathrm{~h}$ ( $88 \%$, entry 15$)$. Additional experiments increasing the catalytic charge (entry 16) or changing solvent and base, resulted in low to modest chemical yields $18-44 \%$ (entries 17-20). From our optimization we conclude that conditions in entries 5 and 15 were the best. However reagents in entry 15 were chosen mainly by the lower cost of palladium catalyst.

With the Suzuki cross-coupling reaction optimized conditions in hand, we synthesized a pool of 3,4-diarylmaleimides substituted at nitrogen with methyl and benzyl group (Table 2).

Thus a wide variety of boronic acids from commercial sources were acquired. We considered those containing electron-donating, electron-attracting, electron-neutral as well as heterocyclic and polyaromatic groups. It is relevant to highlight that some groups like fluorine and chlorine have displayed important biological activities, as consequence were included in the substitution pattern of the prepared molecules in this work.

As we can see, several 3,4-diaryl- $N$-alkylmaleimides were synthesized in modest to excellent yields. As planned, maleimides containing electron-rich (entries 2-3, 6-7, 12-13 and 1516), electron-poor (entries 4-5, 8-10, 14 and 17-19) and neutral aryls (entries 1 and 11) were prepared.

On the other hand, some related 3-bromo-4-aminomaleimides structurally related were synthesized using $\mathbf{1}$, as starting material (Scheme 2).

The compounds 25-27 were conveniently prepared by mixing compound 1 with benzylamine, phenethylamine and 3,4-dimethoxyphenetyl amine respectively. The reaction takes place in two consecutive steps: the first one corresponding to the transamidation intermediates $\mathbf{2 5 a - 2 7 a}$, followed by bromine substitution via a Michael addition-elimination. 
Table 2. Synthesis of 3,4-diaryl- $N$-alkylmaleimides by Suzuki cross-coupling reaction.<smiles>[R]N1C(=O)C(Br)=C(Br)C1=O</smiles><smiles>[R18][R](O)O</smiles>

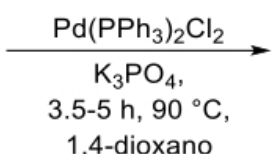

1,4-dioxano<smiles>[R]C1=C([R])C(=O)N([R])C1=O</smiles>

$5-24$

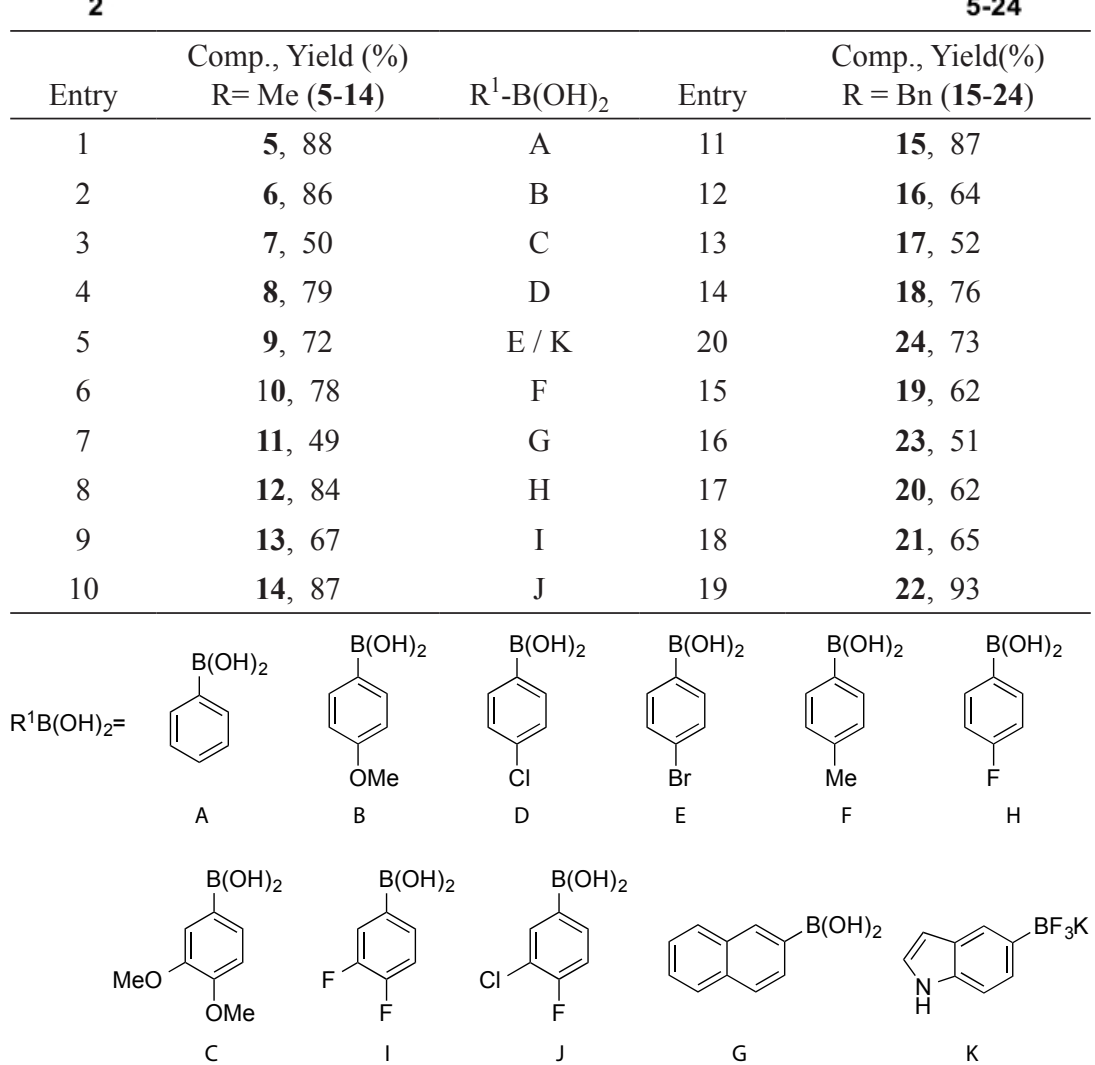
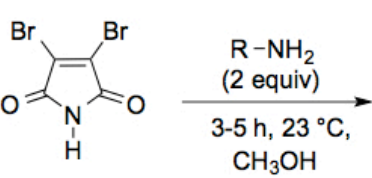

$\mathrm{CH}_{3} \mathrm{OH}$

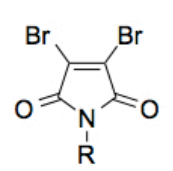

25a-27a

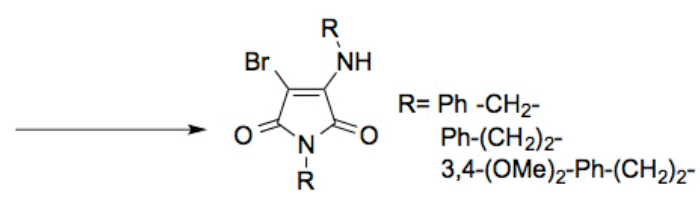

25-27<smiles>O=C1C(Br)C(NCc2ccccc2)C(=O)N1Cc1ccccc1</smiles>

$25,58 \%$

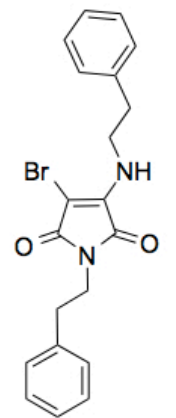

26, $96 \%$

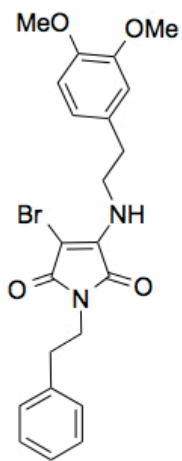

27, $65 \%$

Scheme 2. Synthesis of 3-bromo-4-aminomaleimides 25-27. 


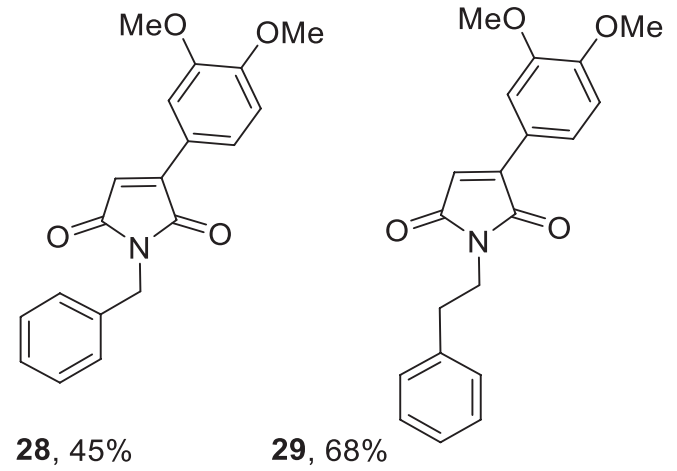

Figure 1. Additional $C$-monoarylmaleimides 28-29 tested.

Finally, compounds 28-29 (monsubstituted maleimides) were synthesized according to the procedure described in Figure 1.

\section{Drug screening \\ BT 026-512N breast cancer cells from primary culture}

BT 026-512N breast cancer cells, obtained from a patient biopsy, who was diagnosed with (left) stage IIB infiltrating ductal breast cancer, were stabilized in primary cell cultures. As shown in Figure 2, these cells were immunoreactive to cytokeratin 19, a breast cancer marker. [12] The synergistic cytotoxic effect exerted by doxorubicin and 3,4-diarylmaleimides derivatives (529) were tested on these primary cell cultures.

\section{Synergistic effect of doxorubicin and 3,4-diarylmaleimides derivatives}

In the present study, the series of 25 3,4-diarylmaleimides derivatives (5-29) synthesized were tested in combination with doxorubicin in BT 026-512N cells from secondary culture. Breast cancer cell cytotoxicity to Dox alone or in combination with 3,4-diarylmaleimides derivatives (5-29) was evaluated by determining the cell proliferation inhibition as a percentage after $72 \mathrm{~h}$ of treatment with concentration range of 2-49 $\mathrm{mM}$ of each derivative as shown in Table 3. Combination of 3,4-diarylmaleimides derivatives $\mathbf{9}, \mathbf{1 6}, \mathbf{2 0}$ and $\mathbf{2 9}$ at concentrations 2.4, 12.5, 26.6 and $8.9 \mathrm{mM}$ respectively with $0.4 \mathrm{mM}$ of Dox showed the best degree of cell proliferation inhibition above two-fold change compared with the cell proliferation inhibition of Dox alone (25.6\%, Figure 3).

Secondary cultures of BT $026-512 \mathrm{~N}$ cells maintained reactivity to cytokeratin 19 antibody showing a stable phenotype as breast cancer cells after subculture for 3,4-diarylmaleimides derivatives testing (data not shown).

\section{Predicted physicochemical and biological activities of 3,4-diarylmaleimides derivatives}

Molinspiration property engine v2014.11, were used to calculate the physicochemical and bioactive theoretical properties of 3,4-diarylmaleimides derivatives, which exerted the highest synergistic cytotoxic effect with Dox. Molinspiration offers a molecular processing and property calculation toolkit written in Java. The toolkit may be used in a batch to process large number of molecules (processing speed is about 10,000 molecules/ minute), or accessed through web interface directly on your intranet. Calculated molecular descriptors may be used for property based virtual screening of large collections of molecules to discard structures without drug-like properties and to pick potential drug candidates. These calculations were performed along with the experimental procedure. Through molecular descriptors such as $\log$ P, Molecular weight, number of Hydrogen donators and acceptors at the molecule, used as the "rule of five", described by Lipinski in 1997, [13] is able to predict drug-likeness in new molecules. The rule states, that most "drug-like" molecules have log P less than 5, molecular weight less than 500, number of hydrogen bond acceptors less than 10, and number of hydrogen bond donors less than 5. Molecules

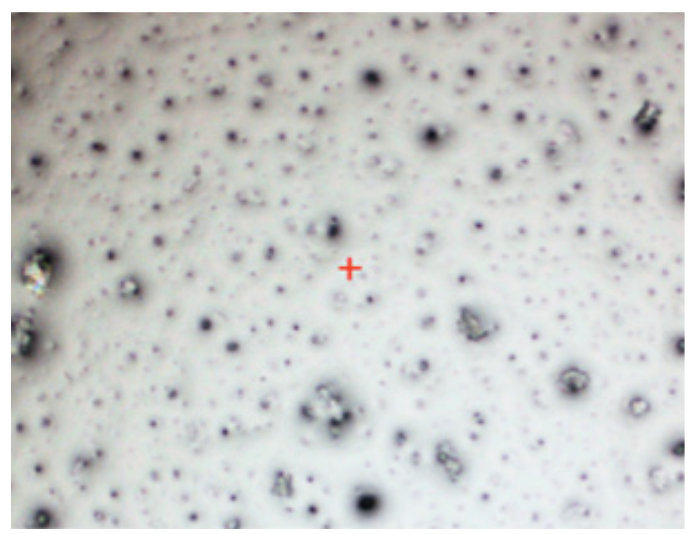

(a)

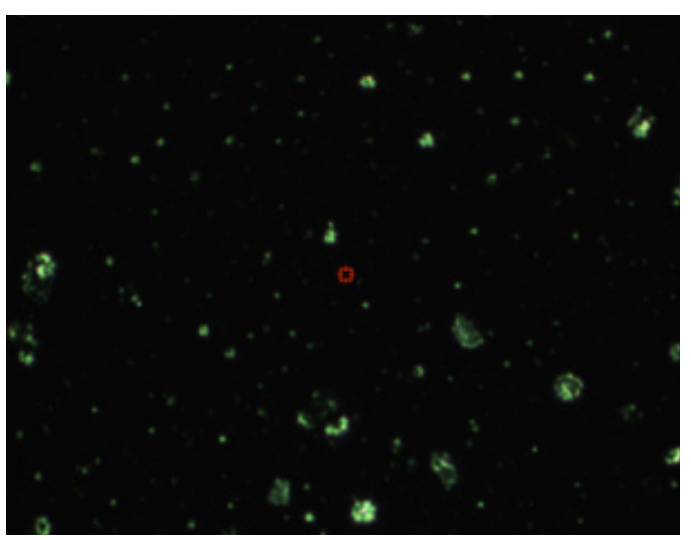

(b)

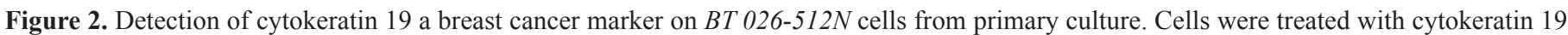

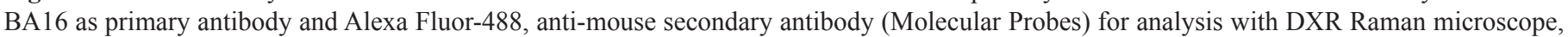

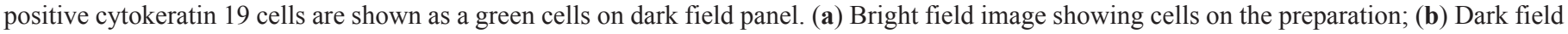
image showing green fluorescent cells positive for cytokeratin 19 . 

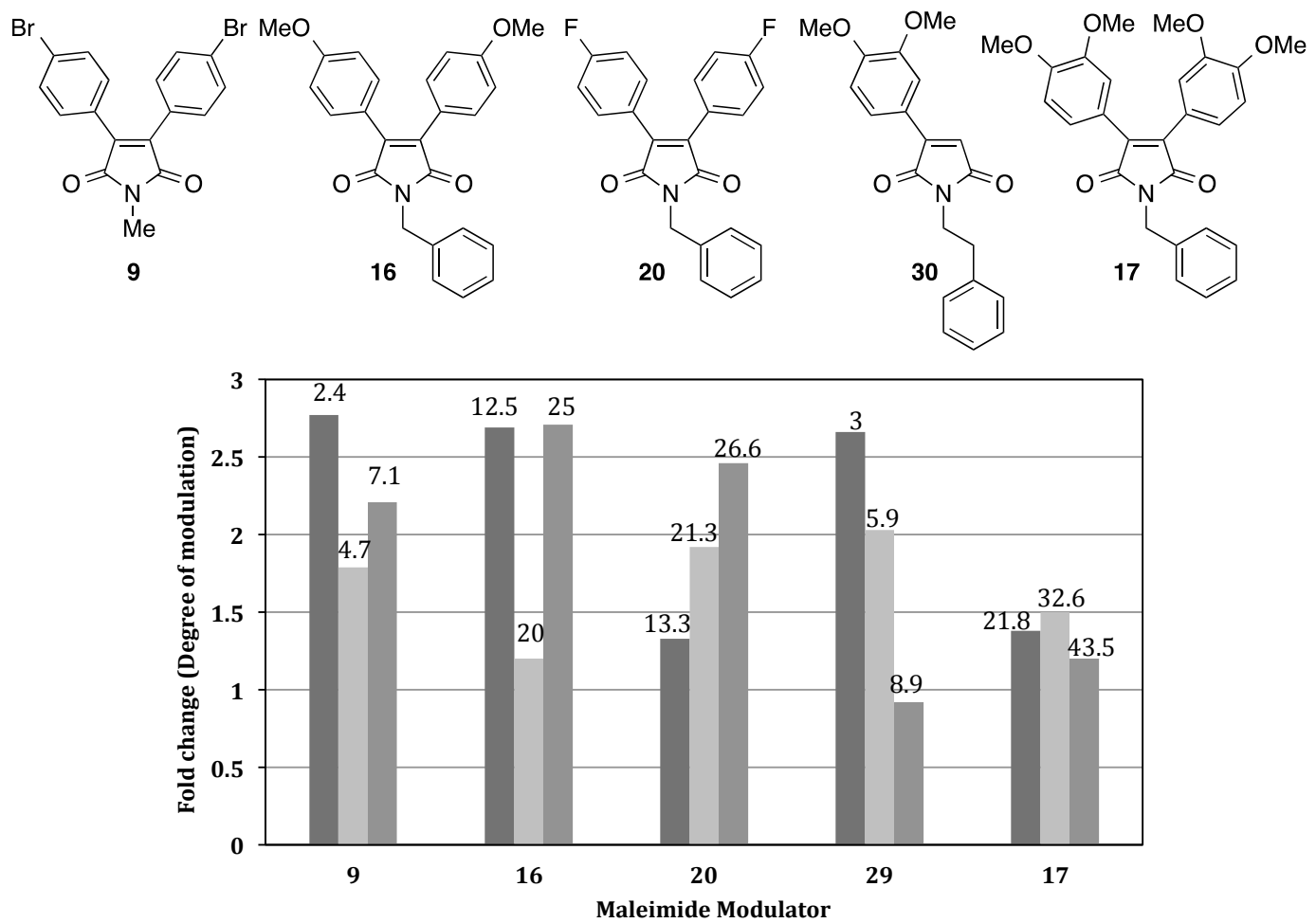

Figure 3. Structure and degree of modulation of 3,4-diarylmaleimides derivatives on Dox cytotoxicity activity. Four maleimide derivatives 9, 16, $\mathbf{2 0}$ and $\mathbf{2 9}$ at three diferent concentrations (values on top of bars, $\mathrm{mM}$ ) and a previously reported compound $\mathbf{1 7}$ were tested in combination with Dox $(0.4 \mathrm{mM})$. Fold change in cytotoxicity effect versus Dox alone was calculated. Structure of tested derivatives are shown above the graphic.

violating more than one of these rules may have problems with bioavailability. In Table 3 the physicochemical properties and drug-likeness of 3,4-diaryl-maleimides are shown.

\section{Discussion}

The screening essays were started by determining cell proliferation inhibition using doxorubicin only (table 3 , entry 1 ). A $25.6 \%$ of cell proliferation inhibition was obtained; this value was used as reference to calculate the relative fold (RF), which is defined as the ratio between cell proliferation inhibition with and without enhancer. Afterwards, compounds 5-29 were tested in combination with a fixed Dox concentration = $0.4 \mathrm{mM}$ and 72 hours of incubation. Moreover, as previously described, compound $\mathbf{1 7}$ was used as reference [11]. Compound 17 is a Ningalin B analogue, obtained by Zhang et al., by linking 3,4-diaryl-substituted pyrrole-2,5-dione with a benzene ring (D-ring) containing various alkyl linkers. Ningalin B is a member of a newly described family of marine natural products which have been reported to act as nontoxic inhibitors of MDR in various cancer cell lines. [11] Compound $\mathbf{1 7}$ at a very high concentration $(100 \mu \mathrm{M})$, did not show any cytotoxicity toward the breast cancer cell lines used nor to normal mouse connective tissue fibroblast. It contains one methylene linker to the D-ring, and it displayed about 2-fold higher enhancer paclitaxel cytotoxic activity than compounds with bismethylene, suggesting that shorter linker in permethyl ningalin B analogues is crucial for modulating Pgp. [11].

Obtained results reveal the expected enhancement of Dox activity for every synthesized maleimide resulting in increasing cell proliferation inhibition. Remarkably by using maleimide modulators 9, 16, 20 and 29 cell proliferation inhibition increases by 2 -fold or more (Table 3 ).

Three different combinatorial concentrations of maleimides were tested. The reference compound $\mathbf{1 7}$ shows a moderate $\mathrm{RF}=1.50$ at $32.6 \mathrm{mM}$ (Table 3, entry 15 ). $N$-methylmaleimide 9 (Table 3, entries 2-4), containing electron-poor bromine group, results in the best biological activity regarding a good $\mathrm{RF}=2.77$ and a lower concentration $(2.4 \mathrm{mM})$. Other concentrations 4.7 and $7.1 \mathrm{mM}$ resulted in a lower RF. On the other hand, monosubstituted electron rich $\mathrm{N}$-benzyl-3,4-dimethoxyphenyl maleimide 29 (Table 3, entries 11-13) shows a comparable but slightly lower good activity with $\mathrm{RF}=2.66$ at $3 \mathrm{mM}$ concentration. For this compound a consistent decreased activity was observed by increasing the modulator concentration. Modulator 16 (Table 3, entries 5-7), shows a good RF=2.69 but in 12.5 and $25 \mathrm{mM}$. Finally, the fluorinated maleimide modulator 20 (Table 3, entries 8-10), gives the highest activity at a 26.6 $\mathrm{mM}$ concentration observing a consistent fold increasing while concentration does.

Drug-like properties may be expressed as the concise balance of several molecular properties and structural features, which determine if a particular molecule is similar to lead 
Table 3. Cell proliferation inhibition values of treatments with doxorubicin and 3,4-diaryl Maleimides derivatives and the respective Fold change.

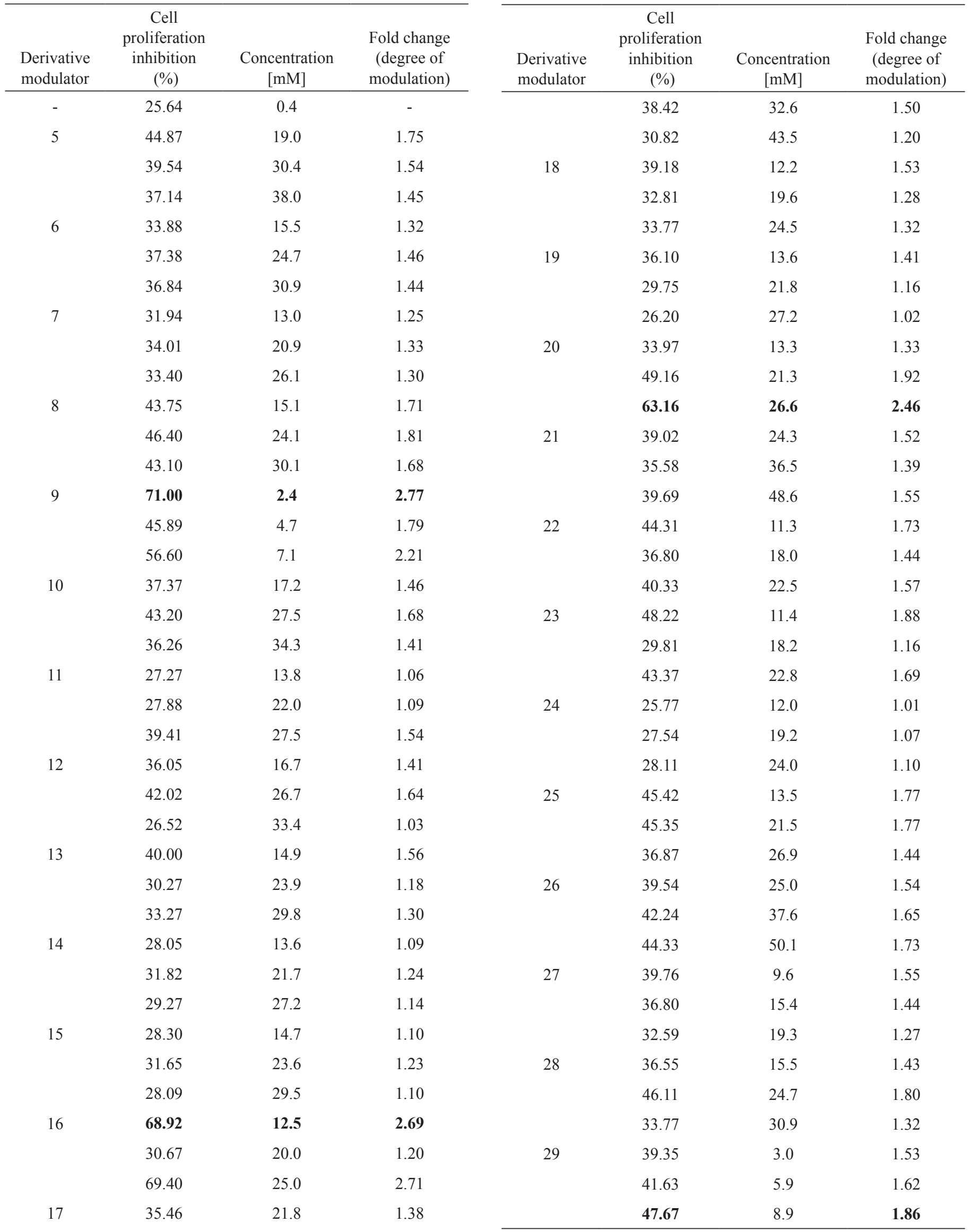


Table 4. Molinspiration analysis of theoretical physicochemical and bioactive properties of $N$-alkylmaleimide derivatives.

\begin{tabular}{|c|c|c|c|c|c|c|c|c|c|}
\hline \multirow[b]{2}{*}{ Comp } & \multirow{2}{*}{$\begin{array}{c}\text { MW } \\
\text { (g/mol) }\end{array}$} & \multicolumn{4}{|c|}{ Physicochemical properties } & \multirow[b]{2}{*}{ Nviol } & \multicolumn{3}{|c|}{ Drug-likeness score } \\
\hline & & $\mathbf{O}+\mathbf{N}$ & $\mathrm{OH}+\mathrm{NH}$ & cLog $P$ & TPSA & & KI & NRL & EI \\
\hline 9 & 421 & 3 & 0 & 4,85 & 39 & 0 & 0,25 & $-0,01$ & $-0,2$ \\
\hline 20 & 375 & 3 & 0 & 5,16 & 39 & 1 & 0,24 & 0,13 & 0,12 \\
\hline 29 & 323 & 5 & 0 & 2,75 & 57 & 0 & 0,33 & 0,03 & 0,06 \\
\hline
\end{tabular}

$M W$ Molecular Weight; $O+N$ number of hydrogen bond acceptors; $O H+N H$ number of hydrogen bond donors; cLog $P$ calculated log P value; TPSA Total Polar Surface Area; Nviol number of violation; KI kinase inhibitor; NRL Nuclear receptor ligand; EI enzyme inhibitor.

drugs. These properties, mainly hydrophobicity, electronic distribution, hydrogen bonding, molecular size, flexibility and the presence of some pharmacophoric influence parameters of a given molecule like bioavailability, distribution, plasma protein binding, bioactivity prediction, toxicity, and metabolic stability. Molinspiration is a chemoinformatic software that can estimate all of the above properties. [15]

Molinspiration software calculations were carried out for the molecules shown in Table 4. Mainly the hydrophilicity or hydrophobicity (cLog P) and Molecular Polar Surface Area (TPSA) parameters were analyzed to estimate the bioavailability of drug molecules. The compounds 9, 16, 29 and 17 show values below 5 , which imply a good membrane penetration accordant to the rule of Lipinski. [13] Compound 20 with slightly higher $\operatorname{cLog} \mathrm{P}=5.16$ will show less water affinity by overpassing the highest limit of 5 for this parameter, incurring in the only violation for the rule of five in this series of molecules. Regarding the TPSA for these five molecules is important to highlight that a value no bigger than $76 \AA^{2}$ was calculated. The value is important by the fact that according to the rule of five, when a drug presents a number higher than $140 \AA^{2}$ a poor intestinal absorption is expected. The compounds 9, 16, 20, 29 and 17 show all of them minor values for this TPSA descriptor. The aforementioned means that a good drug absorption including intestinal absorption, blood-brain barrier penetration as well as bioavailability may be favorable.

Bioactivity prediction by Molinspiration analysis of chemical structures showed the highest scores for kinase inhibitors in the compounds 9, 16, 20, 29 and 17. Molinspiration miscreen engine allows fast prediction of biological activity - virtual screening of large collections of molecules and selection of molecules with the highest probability to show biological activity. The screening is based on identification of fragments or substructure features typical for the active molecules. No information about the 3D structure of receptor is necessary, the set of active molecules (encoded as SMILES or SDfile) is sufficient for training, therefore the procedure may be applied also in the early project stage when detailed information about the binding mode is not yet available. [15]

The predicted activity of the synthetized molecules suggested that the modulation of doxorubicin effect may be mediated through P-gp as previously reported for compound 17. [11,
14] P-gp phosphorylation has been reported as a mechanism of regulation of drug efflux [17], particularly in sensitive and resistant MCF-7 cell lines, an inhibition of a protein kinase $\mathrm{C} \alpha$ $(\mathrm{PKC} \alpha)$ showed an increase of intracellular Dox [16]. This data suggests that drugs $9,16,20,29$ and 17 , could act as potential inhibitors of a kinase and improve the anticancer effect exerted by Dox through modulation of P-gp activity. Experimental evidence is necessary in order to demonstrate its participation as modulator of P-gp activity and its kinase target as predicted in the Molinspiration analysis.

The rule of five is a set of defined parameters, to predict if a chemical compound has a promising or viable pharmacological or biological activity as drug in oral administration. These parameters are 1) The molecule should not contain more than 5 hydrogen bond donors, 2) No more than 10 hydrogen bond acceptors, 3) The molecular weight should be lower than 500, 4) The value for cLog P should not be higher than five. The parameters in the rule of five were fully covered for the set of our synthesized maleimides excluding to $\mathbf{2 0}$ with only 1 violation in cLog P. Remarkably compounds 9, 16, 20 and 29 show the highest activity in the series of 3,4-diarylmaleimides synthesized.

Compound 9 contains bromine in its structure, which could suggest this bulky element is necessary to block P-gp pump and allow an increased intracellular concentration of Dox. Compound 20 contains instead of bromine, fluorine which potentially interacts in less effective way with P-gp pump, due to its minor atomic size. This is reflected by its slightly lower degree of modulation on Dox cytotoxicity activity compared with compound 9.

As previously reported for Ningalin B analogues [11, 14], partial or full methylation of phenol rings might significantly improve P-gp-modulating activity, this structural characteristic is shared by compounds $\mathbf{1 6}$ and $\mathbf{2 9}$ and the reference compound 17. In addition, the results obtained with Molinspiration analysis that predict biological activity of these compounds, suggest that methylation of phenol rings allows interaction with P-gp pump. On the other hand, compound $\mathbf{1 6}$ and $\mathbf{2 9}$ improved the modulation effect on Dox cytotoxicity activity compared with reference compound $\mathbf{1 7}$, however in this work, our compounds showed higher activity with less methylated phenolic groups compared with compound 17. 


\section{Conclusions}

In summary for this primary breast cancer cell culture the 3,4-bisarylmaleimide core is a promising structure in a potential combination treatment with doxorubicin. The electron-deficient group in a 3,4-diarylmaleimide is a key structural factor. In addition, bigger substituents in both aryl and nitrogen in maleimide core, such as bromine and benzyl, increase the activity. Both characteristics in the same molecule not improved the cytotoxic effect according to this observation. On the other side $\mathrm{N}$-alkyl or benzyl substituted maleimides containing electron-donating groups at the aryl ring show also excellent activity. Those electron-rich and monoarylated maleimides will be in this sense the better combination. So big electron-poor and small at nitrogen or electron-rich monoarylated with big alkyl group at nitrogen is the other good possible combination.

\section{Supplementary Materials}

A copy of ${ }^{1} \mathrm{H}$ and ${ }^{13} \mathrm{C}$ NMR for compounds $\mathbf{1 - 2 9}$ as well as biological experimentation full data for all described maleimides are available online.

\section{Acknowledgments}

We gratefully thanks to FOMIX (CONACyT-CONCyTEG) GTO-2012-C03-194610 for financial support and fellowship for J.R. Gutiérrez-Cano. We acknowledge the facilities from the DCNE, Chemistry Department, Guanajuato University in the National Laboratory UG-CONACyT (LACAPFEM) for full characterization. We thanks to CONACyT for fellowships to V. Ramadoss, P.Nahide and Y. Satkar. We gratefully give thanks to the National Institute of Cancerology for providing tissue BT025-512N for biological essays. Also we thanks to Dr. $\mathrm{J}$. Gembe for providing doxorubicin sample.

\section{References}

1. Kamangar, F.; Dores, G.M.; Anderson, W.F. J. Clin. Oncol 2006, 24(14), 2137-2150. doi: 10.1200/JCO.2005.05.2308.
2. Binaschi, M.; Bigioni, M.; Cipollone, A.; Rossi, C.; Goso, C.; Maggi, C.A.; Capranico, G.; Animati, F. Anti-Cancer Agents 2001, 1(2), 113-130. DOI: 10.2174/1568011013354723.

3. Minotti, G.; Menna, P.; Salvatorelli, E.; Cairo, G.; Gianni, L. Anthracyclines. Pharmacol Rev 2004, 56(2), 185-229. doi: 10.1124/ pr.56.2.6.

4. Tan, C.; Tasaka, H.; Yu, K.P.; Murphy, M.L.; Karnofsk, D.A. Cancer 1967, 20(3), 333-353. DOI: 10.1002/1097-0142

5. Arcamone, F.; Cassinelli, G.; Fantini, G.; Grein, A.; Orezzi, P.; Pol, C.; Spalla, C. Biotechnol Bioeng 1969, 11(6), 1101-1110. DOI: 10.1002/bit.260110607.

6. Goldenberg, G.J.; Wang, H.; Blair, G.W. Cancer Res 1986, 46, 2978-2983. Available on line: http://cancerres.aacrjournals.org/ content/46/6/2978.long (accessed on 18 May 2016)

7. Rhinehart, J.J.; Lewis, R.P.; Balcerzak, S.P. Ann Intern Med 1974, 81, 475-478. doi:10.7326/0003-4819-88-2-168.

8. Lehne, G. Curr Drug Targets 2000, 1(1), 85-99. DOI: 10.2174/ 1389450003349443.

9. Kartner, N.; Riordan, J.R.; Ling, V. Science 1983, 221, 1285-1288. DOI: $10.1126 /$ science.6137059.

10. Tsuruo, T.; Iida, H.; Tsukagoshi, S.; Sakurai, Y. Cancer Res 1981, 41, 1967-1972. Available on line: http://cancerres.aacrjournals. org/content/41/5/1967.long (accessed on 19 May 2016).

11. Zhang, P.Y.; Wong, I.L.K.; Yan, C.S.W.; Zhang, X.Y.; Jiang, T.; Chow, L.M.C.; Wan, S.B. J Med Chem 2010, 53, 5108-5120. DOI: $10.1021 / \mathrm{jm} 100035 \mathrm{c}$.

12. Lacroix M. Endocr Relat Cancer. 2006, 13, 1033-1067. doi: 10.1677/ERC-06-0001.

13. Lipinski, C. A., Lombardo, F., Dominy, B. W.; Feeney, P. J. $A d v$ Drug Deliver Rev. 2001, 64, 3-26. doi:10.1016/S0169-409X (00)00129-0.

14. Bin, J. W., Wong, I. L., Hu, X., Yu, Z. X., Xing, L. F., Jiang, T., ... \& Biao, W. S. J Med Chem 2013, 56(22), 9057-9070. Doi: 10.1021/jm400930e.

15. Miscreen-Molinspiration Fragment-based Virtual Screening Engine written in Java; http://www.molinspiration.com/docu/miscreen/index.html. Accessed May 24, 2016.

16. Kim, C. W.; Asai, D.; Kang, J. H.; Kishimura, A.; Mori, T.; Katayama, Y. Tumor Biol. 2015, 37, 1901-1908. DOI 10.1007/s13277015-3963-4.

17. Meyers, M. B. Cancer Commun, 1989, 1(4), 233-241. 


\title{
Microwave-assisted synthesis of ethyl 7-chloro-4-oxo-1,4-dihydro-1,8- naphthyridine-3-carboxylate by the Grohe-Heitzer reaction
}

\author{
Socorro Leyva-Ramos, ${ }^{* 1}$ Elisa Leyva, ${ }^{1}$ Jaime Cardoso-Ortiz ${ }^{2}$ and Hiram Hernández-López ${ }^{2}$ \\ 1 Facultad de Ciencias Químicas, Universidad Autónoma de San Luis Potosí, 78210, San Luis Potosí, SLP, México. \\ Tel: 524448262440 Ex 6476. e-mail: sleyva@uaslp.mx \\ 2 Unidad Académica de Ciencias Químicas, Universidad Autónoma de Zacatecas, 98160, Zacatecas, Zac. México.
}

Received September $2^{\text {nd }}, 2016$; Accepted January $17^{\text {th }}, 2017$.

\begin{abstract}
A simple and efficient two-step method was implemented for the synthesis of ethyl 7-chloro-4-oxo-1,4-dihydro-1,8-naphthyridine-3-carboxylate. Comparing with the reported Grohe-Heitzer reaction, the time and the reaction steps have been reduced using microwave irradiation. This compound is an important intermediate for the preparation of naphthyridone derivatives which have received significant attention due to their broad spectrum of biological activity. Keywords: Grohe-Heitzer reaction; 1,8-naphtyridone; microwave irradiation; tautomeric equilibrium.
\end{abstract}

\section{Introduction}

The 1,8-naphthyridone derivatives have received significant attention due to their exceptionally broad spectrum of biological activities. The first 1,8-naphthyridone group was nalidixic acid used as a synthetic quinolone antibiotic $[1,2]$. However, this quinolone showed activity only against Gram-negative microorganisms. Subsequent structural modifications of this quinolone led to a wide range of biological properties established them as potent scaffolds in therapeutic and medicinal research. The broad spectrum of activities includes antibacterial $[3,4]$, antitumor [5-9], antiviral [10, 11] and some antimycobacterial activities $[12,13]$ as well as anti-inflammatory activity [14-17]. The structural features of the more potent, newer generation quinolones such as tosufloxacin, trovafloxacin, enoxacin and gemifloxacin (Figure 1) include C-6 fluorine and a C-7 nitrogen-containing heterocycle including piperazine or pyrrolidine into the 1,8-naphthyridone group $[3,4,16]$.

In spite of a significant number of fluoroquinolones being approved for treatment of bacterial infections [18]; there is still need for developing new derivatives that could overcome the emerging problem represented by bacterial chemoresistance. Furthermore, some antibacterial quinolones have important significant side effects. For example, trovafloxacin was recently removed due to its liver toxicity [19].

Numerous synthetic methods have been reported for the preparation of quinolones under conventional conditions; however, these methods describe long reaction times, low yields and elaborated work-up procedures. In this paper, we describe a fast microwave-assisted synthesis for the preparation of ethyl
Resumen. Se implementó un método simple y eficiente de dos etapas para la síntesis de 7-cloro-4-oxo-1,4-dihidro-1,8-naftiridin-3-carboxilato de etilo. Comparado con la reacción de Grohe-Heitzer reportada, el tiempo y los pasos de reacción se redujeron empleando irradiación de microondas. Este compuesto es un importante intermediario para la preparación de derivados de naftiridonas, los cuáles han recibido una considerable atención debido a su amplio espectro de actividad biológica. Palabras clave: Reacción de Grohe-Heitzer; 1,8-naftiridona; irradiación de microondas; equilibrio tautomérico.<smiles>[R]c1nc2c(cc1F)c(=O)c(C(=O)O)cn2[R2]</smiles>

Nalidixic acid

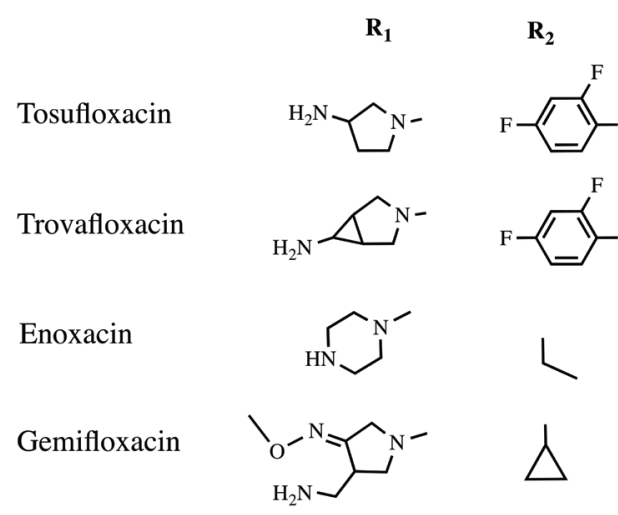

Figure 1. Some antibacterial naphthyridones.

7-chloro-4-oxo-1,4-dihydro-1,8-naphthyridine-3-carboxylate reported in the literature $[5,6,20,21]$.

\section{Results and Discussion}

The 1,8-naphthyridine ring can be prepared by two-step synthesis of $\mathbf{3}$ as showed on Scheme 1. First, 2,6-dichloronicotinic 
acid (1) is reacted with 1,1-carbonyldiimidazol (CDI) to give an imidazolide intermediate at room temperature and 2-2.5 h, according to the literature $[5,6,21]$. Which reacts with ethyl malonate potassium, $\mathrm{MgCl}_{2}$ and triethylamine to generate ethyl 3-(2,6-dichloropyridin-3-yl)-3-oxopropanoate (2) using intervals of room temperature to $60^{\circ} \mathrm{C}$ and $1-15 \mathrm{~h}$ as reactions conditions, reaching $59-93 \%$ yield. Nevertheless, these conditions were improved using microwave radiation, decreasing the reaction time to $5 \mathrm{~min}$ for the synthesis of imidazolide intermediate, the rest of the reaction was performed according to a previous report described in the literature with a $93 \%$ yield.

Then, a usual route of synthesis proposes that molecule 2 reacts with acetic anhydride and triethyl orthoformate, to generate an intermediate vinyl ether in 55 to $90 \%$ yield, using a nitrogen atmosphere and temperatures between $130-140{ }^{\circ} \mathrm{C}$. Following by the addition of an amine or amine substituted at room temperature for $1-5 \mathrm{~h}$ or overnight, resulting 55 to $90 \%$ yield. After this, the synthesized intermediate proceeds to cyclization reaction using $50-60^{\circ} \mathrm{C}$ and time lapse of 1-3 h, with $63-92 \%$ yield of compound 3 . A pathway with three-step synthesis that can be easily converted into one-pot synthesis. The molecule 2 reacts with acetic anhydride and triethyl orthoformate under $\mathrm{MW}$ conditions $\left(70 \mathrm{~W}, 140{ }^{\circ} \mathrm{C}, 3.6 \mathrm{~min}\right.$ ) to yield an intermediate vinyl ether in which $\mathrm{CeCl}_{3}$ and either $\mathrm{NH}_{3}$ or $\left(\mathrm{NH}_{4}\right)_{2} \mathrm{CO}_{3}$ was added to produce a vinyl amine using $100 \mathrm{~W}$ and $100{ }^{\circ} \mathrm{C}$ that allowed easily undergoes cyclization at the same time. The crude product obtained, was purified by a simple column chromatography using hexane to obtain the 1,8-naphythyridone product 3 . The yields using $\mathrm{NH}_{3}$ or $\left(\mathrm{NH}_{4}\right)_{2} \mathrm{CO}_{3}$ were $73 \%$ and $75 \%$ respectively.

Compounds $\mathbf{2}$ and $\mathbf{3}$ were confirmed by ${ }^{1} \mathrm{H}$ NMR and FTIR spectroscopy [19], both presented a keto-enol tautomeric equilibrium as shown in Scheme 2. Tautomer 2a had a $\mathrm{CH}_{2}$ signal (4.09 ppm) while 2b gave a broad $\mathrm{OH}$ signal (12.54 ppm) and a vinyl $\mathrm{H}$ signal (5.72 ppm). In the case of $\mathbf{3 a}$, a vinyl $\mathrm{H}$ signal $(8.53 \mathrm{ppm})$ and a broad $\mathrm{NH}$ signal $(1.59 \mathrm{ppm})$ were observed while $3 \mathbf{b}$, an $\mathrm{OH}$ signal (2.57 ppm) was obtained. According to an extensive aromatic system and intramolecular hydrogen bond, the enol tautomer $\mathbf{3 b}$ was strongly favored. Furthermore, the FT-IR spectra of $\mathbf{2}$ and $\mathbf{3}$ showed absorbance bands corresponding to the presence of $\mathrm{O}-\mathrm{H}$ alcohol, $\mathrm{C}=\mathrm{O}$ enolic ester, as well as a $\mathrm{C}=\mathrm{O}$ ester and a ketone.

\section{Experimental}

The reactions were carried out using a CEM monomode MW synthesizer with a CEM Discover System workstation and monitored by thin-layer chromatography (TLC) using silica gel 60 F254 plates, eluting with hexane/ethylacetate. FT-IR spectra were obtained in $\mathrm{KBr}$ pellets on a Fourier Nicolet (iS10 FT-IR) spectrometer. NMR spectra were recorded on a Varian Mercury Plus $400 \mathrm{MHz}$ spectrometer. Mass spectra were done on a JEOL MStation JMS-700 apparatus.

\section{Procedure and spectral data}

\section{Ethyl 3-(2,6-dichloropyridin-3-yl)-3-oxopropanoate (2a) and ethyl 3-(2,6-dichloropyridin-3-yl)-3-hydroxyacrylate (2b)}

To a solution of 2,6-dichloronicotinic acid $(0.20 \mathrm{~g}, 1.04 \mathrm{mmol})$ in THF- $\mathrm{CH}_{3} \mathrm{CN}(1: 1,3.0 \mathrm{~mL})$ was added 1,1-carbonyldiimidazole $(0.19 \mathrm{~g}, 1.17 \mathrm{mmol})$. The resulting mixture was stirred and heated using MW ( 5 Watts power at $50^{\circ} \mathrm{C}$ for $5 \mathrm{~min}$ ). This crude imidazolide solution was used without purification in the following step. To a solution of ethyl malonate potassium salt (0.19 g, $1.09 \mathrm{mmol})$ in $\mathrm{CH}_{3} \mathrm{CN}(2.50 \mathrm{~mL})$ was added dropwise a mixture of $\mathrm{MgCl}_{2}(0.14 \mathrm{~g}, 1.52 \mathrm{mmol})$ and $\mathrm{Et}_{3} \mathrm{~N}(1.50 \mathrm{~mL})$ under ice cooling. After the mixture was stirred at room temperature for $5 \mathrm{~h}$, the imidazolide was added. The reaction mixture was stirred at room temperature for $15 \mathrm{~h}$, poured onto ice water $(5$ $\mathrm{mL}$ ) resulting in a $\mathrm{pH}$ about 11 , so we acidified this mixture using concentrated $\mathrm{HCl}$ to $\mathrm{pH}=6$. The crude product was extracted with AcOEt, dried with $\mathrm{Na}_{2} \mathrm{SO}_{4}$ and concentrated under vacuum to give product 2, obtained as a yellow oil ( $93 \%$ yield). The product consisted of a mixture of the ketone $2 \mathrm{a}$ and the enol 2b tautomers (confirmed by spectroscopic methods) [6].

IR (KBr) $\mathrm{n}_{\max } 3133$ (C-H aromatic), 2984, 2936 (C-H aliphatic), 1761 ( $\mathrm{C}=\mathrm{O}$ ester $), 1736(\mathrm{C}=\mathrm{O}$ ketone $), 1631(\mathrm{C}=\mathrm{O}$ ester enolic), $1573(\mathrm{C}=\mathrm{C}$ aromatic), $1541(\mathrm{C}=\mathrm{N}$ aromatic $), 1385$ and 1341 (C-N aromatic), 1282, 1242 and 1141 (C-O ester and alcohol), 1095 and 1020 (C-Cl aromatic), 843 and $772(\mathrm{C}-\mathrm{H}$<smiles>O=C(O)c1ccc(Cl)nc1Cl</smiles>

1

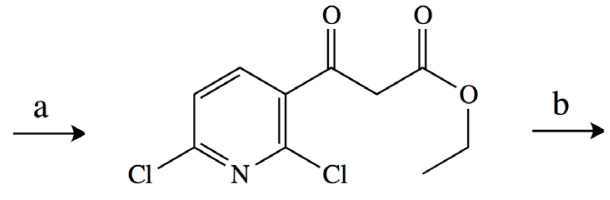

2<smiles>CCOC(=O)c1c[nH]c2nc(Cl)ccc2c1=O</smiles>

3

(a) 1) $\mathrm{CDI}, \mathrm{THF} / \mathrm{CH}_{3} \mathrm{CN}, \mathrm{MW}, 5 \mathrm{~min}$; 2) $\mathrm{EtOCOCH}_{2} \mathrm{COOK}, \mathrm{MgCl}_{2}, \mathrm{Et}_{3} \mathrm{~N}$, RT;

(b) 1) $\left.\mathrm{CH}(\mathrm{OEt})_{3}, \mathrm{Ac}_{2} \mathrm{O}, \mathrm{MW}, 3.6 \mathrm{~min}, 2\right) \mathrm{CeCl}_{3}, \mathrm{NH}_{3}$ or $\left(\mathrm{NH}_{4}\right)_{2} \mathrm{CO}_{3} / 1,4$-dioxane, $\mathrm{MW}, 15$ min.

Scheme 1. Microwave-assisted synthesis of ethyl 7-chloro-4-oxo-1,4-dihydro-1,8-naphthyridine-3-carboxylate. 
Socorro Leyva-Ramos et al.

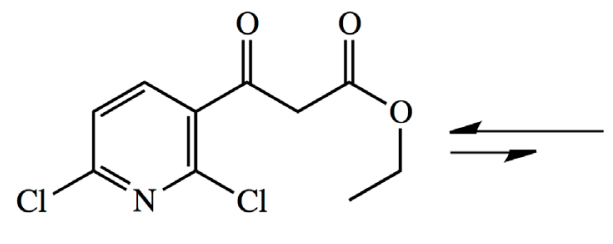

$\mathbf{2 a}$<smiles>CCOC(=O)/C=C(\O)c1ccc(Cl)nc1Cl</smiles>

2b<smiles>CC#CC#CC</smiles>

3a<smiles>CCOC(=O)c1cnc2nc(Cl)ccc2c1O</smiles>

3b

Scheme 2. Tautomeric equilibrium.

aromatic out of plane) $\mathrm{cm}^{-1}$. MS, $m / z(\%): 262.0\left(\mathrm{M}^{+}, 21\right), 216$ (13), 167 (32), 149 (85), 136 (46).

(2a) ${ }^{1} \mathrm{H} \mathrm{NMR}\left(\mathrm{CDCl}_{3} 400 \mathrm{MHz}\right) \delta 1.26(\mathrm{t}, 3 \mathrm{H}, J=7.20$ Hz), 4.09 (s, 2 H), 4.20 (q, $2 \mathrm{H}, J=7.20 \mathrm{~Hz}), 7.40$ (d, $1 \mathrm{H}, J=$ $8.0 \mathrm{~Hz}), 7.98(\mathrm{~d}, 1 \mathrm{H}, J=8.0 \mathrm{~Hz}) .{ }^{13} \mathrm{C} \mathrm{NMR}\left(\mathrm{CDCl}_{3} 400 \mathrm{MHz}\right)$ $\delta 192.41(\mathrm{C}=\mathrm{O}$ ketone $), 172.39(\mathrm{C}=\mathrm{O})$ ester, 152.93, 141.69, 141.41, 140.85 and 123.04, (aromatic C), 60.38, $48.68\left(\mathrm{CH}_{2}\right)$ and $14.01\left(\mathrm{CH}_{3}\right)$.

(2b) ${ }^{1} \mathrm{H}$ NMR $\left(\mathrm{CDCl}_{3} 400 \mathrm{MHz}\right) \delta 1.35$ (t, $3 \mathrm{H}, J=7.20$ $\mathrm{Hz}), 4.29$ (q, $2 \mathrm{H}, J=7.20 \mathrm{~Hz}), 5.72$ (s, $1 \mathrm{H}), 7.36$ (d, $1 \mathrm{H}, J=$ $8.0 \mathrm{~Hz}), 7.94(\mathrm{~d}, 1 \mathrm{H}, J=8.0 \mathrm{~Hz}), 12.54(\mathrm{~s}, 1 \mathrm{H}) .{ }^{13} \mathrm{C} \mathrm{NMR}$ $\left(\mathrm{CDCl}_{3} 400 \mathrm{MHz}\right) \delta 171.16(\mathrm{C}=\mathrm{O})$ ester, 166.57 (C-OH alcohol), 152.94, 141.69, 141.41, 132.47 and 123.04 (aromatic C), 123.46 (vinyl $\mathrm{C}$ ), $61.78\left(\mathrm{CH}_{2}\right)$ and $14.16\left(\mathrm{CH}_{3}\right)$.

\section{Ethyl 7-chloro-4-oxo-1,4-dihydro-1,8-naphthyridine-3- carboxylate (3a) and ethyl 7-chloro-4-hydroxy-1,8- naphthyridine-3-carboxylate (3b)}

A mixture of $2(0.40 \mathrm{~g}, 1.50 \mathrm{mmol})$ and acetic anhydride $(0.36 \mathrm{ml}, 2.25 \mathrm{mmol})$ was heated using MW at 70 Watts until it reached $140^{\circ} \mathrm{C}$. Then triethyl ortoformate was added $(0.38 \mathrm{~mL}, 3.75 \mathrm{mmol})$ stirring under MW heating $(70 \mathrm{~W}$, $140^{\circ} \mathrm{C}$ ) for $3.60 \mathrm{~min}$. The reaction mixture changed from yellow to an intense red color. AcOEt and $\mathrm{CH}_{3} \mathrm{CO}_{2} \mathrm{H}$ were distilled off under reduced pressure. The resulting crude product was mixed with $\mathrm{CeCl}_{3} .7 \mathrm{H}_{2} \mathrm{O}(5.60 \mathrm{mg})$ and stirred for $10 \mathrm{~min}$. Then, a solution of either $\mathrm{NH}_{3}$ or $\left(\mathrm{NH}_{4}\right)_{2} \mathrm{CO}_{3}(2.50 \mathrm{mmol})$ in $5.10 \mathrm{~mL}$ of 1,4-dioxane was added in three fractions to the mixture under open vessel MW at 100 Watts until it reached $100^{\circ} \mathrm{C}$ for $15 \mathrm{~min}$. The crude product was purified by column chromatography using hexane as the mobile phase to obtain $\mathbf{3}$ as colorless solid in a mixture of ketone $\mathbf{3 a}$ and enol $\mathbf{3 b}$ tautomers with m.p. $283-286^{\circ} \mathrm{C}$ [20]. $73 \%$ yield was achieved by using $\mathrm{NH}_{3}$, while in the case of $\left(\mathrm{NH}_{4}\right)_{2} \mathrm{CO}_{3}$ the yield was $75 \%$. IR (KBr) $\mathrm{n}_{\max } 3423$ (O-H alcohol), 3071 (C-H aromatic), 2986, 2926 and 2852 (C-H aliphatic), 1723 (C=O ester), 1664 $(\mathrm{C}=\mathrm{O}$ ketone $), 1623(\mathrm{C}=\mathrm{O}$ ester enolic $), 1594(\mathrm{C}=\mathrm{C}$ aromatic), $1550(\mathrm{C}=\mathrm{N}$ aromatic), 1406 (C-N amine), 1385 (C-N aromatic), 1289, 1219 and 1130 (C-O ester and alcohol), 1073 and1016 (C-Cl aromatic), 796 (C-H aromatic out of plane) $\mathrm{cm}^{-1}$. MS, $m / z(\%): 222\left[\left(\mathrm{M}-\mathrm{CO}-\mathrm{H}_{2}\right)^{+}, 9\right], 220$ (16), 167 (20), 154 (100), 149 (79), 137 (55).

(3a) ${ }^{1} \mathrm{H}$ NMR $\left(\mathrm{CD}_{3} \mathrm{COCD}_{3} 400 \mathrm{MHz}\right) \delta 1.41(3 \mathrm{H}, \mathrm{t}, J=9$ $\mathrm{Hz}), 1.59$ (1 H, bs, NH), $4.42(2 \mathrm{H}, \mathrm{q}, J=9 \mathrm{~Hz}), 7.36(1 \mathrm{H}, \mathrm{d}, J$ $=10 \mathrm{~Hz}), 8.15(1 \mathrm{H}, \mathrm{d}, J=10 \mathrm{~Hz}), 8.53(1 \mathrm{H}, \mathrm{s}) .{ }^{13} \mathrm{C} \mathrm{NMR}$ $\left(\mathrm{CDCl}_{3} 400 \mathrm{MHz}\right) \delta 173.86(\mathrm{C}=\mathrm{O}$ ketone $), 164.03(\mathrm{C}=\mathrm{O}$ ester $)$, $159.53,155.80,141.96,123.42$ and 120.56 (aromatic $\mathrm{C}$ ), 142.23 and 116.80 (vinyl C), $62.32\left(\mathrm{CH}_{2}\right)$ and $14.10\left(\mathrm{CH}_{3}\right)$.

(3b) ${ }^{1} \mathrm{H}$ NMR $\left(\mathrm{CD}_{3} \mathrm{COCD}_{3} 400 \mathrm{MHz}\right) \delta 1.40(3 \mathrm{H}, \mathrm{t}, J=9$ $\mathrm{Hz}), 2.57$ (1 H, s, OH), $4.42(2 \mathrm{H}, \mathrm{q}, J=9 \mathrm{~Hz}), 7.27(1 \mathrm{H}, \mathrm{s})$, $7.46(1 \mathrm{H}, \mathrm{d}, J=10 \mathrm{~Hz}), 8.52(1 \mathrm{H}, \mathrm{d}, J=10 \mathrm{~Hz}) .{ }^{13} \mathrm{C} \mathrm{NMR}$ $\left(\mathrm{CDCl}_{3} 400 \mathrm{MHz}\right) \delta 163.46(\mathrm{C}=\mathrm{O}$ ester $), 163.08(\mathrm{C}-\mathrm{OH}$ alcohol), 156.67, 154.95, 148.29, 139.06, 122.78, 111.17 and 110.92 (aromatic $\mathrm{C}), 62.12\left(\mathrm{CH}_{2}\right)$ and $14.15\left(\mathrm{CH}_{3}\right)$.

\section{Conclusion}

An improved Grohe-Heitzer methodology [21-24] was developed by the use of microwave energy reducing $2.5 \mathrm{~h}$ to 5 min for the synthesis of the intermediate imidazolide. Which was employed in the generation of ethyl 3-(2,6-dichloropyridin-3-yl)-3-oxopropanoate with $93 \%$ yield, while the preparation of ethyl 7-chloro-4-oxo-1,4-dihydro-1,8-naphthyridine-3-carboxylate was made as one-pot reaction with $73 \%$ yield resulting in shorter reaction times and cleaner products. This useful alternative procedure could be helpful to prepare the skeleton of 1,8-naphthyridone agents. 


\section{Acknowledgment}

We wish to thank CONACyT for their financial support (Grant $82585)$ as well as scholarship (218200).

\section{References}

1. Lesher, G. Y.; Froelich, E. J.; Gruett, M. D.; Bailey, J. H.; Brundage, R. P. J. Med. Chem., 1962, 5, 1063-1065.

2. Ahmed, N. S.; Alfooty, K. O.; Khalifah, S.S. J. Chem., 2014, 2014, 1-8.

3. Feng, L. S.; Lv, K.; Liu, M. L.; Wang, S.; Zhao, J.; You, X.; Li, S. J.; Cao, J.; Guo, H. Y. Eur. J. Med. Chem., 2012, 55, 125-136.

4. Lv, K.; Liu, M.; Feng, L.; Sun, L.; Sun, Y.; Wei, Z.; Guo, H. Eur. J. Med. Chem., 2012, 47, 619-625.

5. Tomita, K.; Tsuzuki, Y.; Shibamori, K.; Tashima, M.; Kajikawa, F.; Sato, Y.; Kashimoto, S.; Chiba, K.; Hino, K. J. Med. Chem., 2002, 45, 5564-5575.

6. Tsuzuki, Y.; Tomita, K.; Shibamori, K.; Sato, Y.; Kashimoto, S.; Chiba, K. J. Med. Chem., 2004, 47, 2097-2109.

7. Srivastava, S. K.; Jha, A.; Agarwal, S. K.; Mukherjee, R.; Burman, A. C. Anticancer Agents Med. Chem., 2007, 7, 685-709.

8. Advani, R. H.; Hurwitz, H. I.; Gordon, M. S.; Ebbinghaus, S. W.; Mendelson, D. S.; Wakelee, H. A.; Hoch, U.; Silverman, J. A.; Havrilla, N. A.; Berman, C. J.; Fox, J. A.; Allen, R. S.; Adelman, D. C. Clin. Cancer Res., 2010, 16, 2167-2175.

9. Hwang, Y. J.; Chung, M. L.; Sohn, U. D.; Im, C. Korean J. Physiol. Pharmacol., 2013, 17, 517-523.

10. Massari, S.; Daelemans, D.; Barreca, M.; Knezevich, A.; Sabatini, S.; Cecchetti, V.; Marcello, A.; Pannecouque, C.; Tabarrini, O. J. Med. Chem., 2010, 53, 641-648.

11. Donalisio, M.; Massari, S.; Argenziano, M.; Manfroni, G.; Cagno, V.; Civra, A.; Sabatini, S.; Cecchetti, V.; Loregian, A.; Cavalli, R.; Lembo, D.; Tabarrini, O. J. Med. Chem., 2014, 57, 5649-5663.
12. Dinakaran, M.; Senthikumar, P.; Yogeeswari, P.; Sriram, D. Biomed. Pharmacother., 2009, 63, 11-18.

13. Aboul-Fadl, T.; Bin-Jubair, F. A. S.; Aboul-Wafa, O. Eur. J. Med. Chem., 2010, 45, 4578-4586.

14. Manera, C.; Cascio, M. G.; Benetti, V.; Allará, M.; Tuccinardi, T.; Martinelli, A.; Saccomanni, G.; Vivoli, E.; Ghelardini, C.; Di Marzo, V.; Ferrarini, P. L. Bioorg. Med. Chem. Lett., 2007, 15, 6505-6510.

15. Srivastava, S.K.; Jaggi, M.; Singh, A.T.; Madan, A.; Rani, N.; Vishnoi, M.; Agarwal, S.K.; Mukherjee, R.; Burman, A.C. Bioorg. Med. Chem. Lett., 2007, 17, 6660-6664.

16. Kumar, V.; Jaggi, M.; Singh, A. T.; Maddan, A.; Sanna, V.; Singh, P.; Sharma, P. K.; Irchhaiya, R.; Burman, A. C. Eur. J. Med. Chem., 2009, 44, 3356-3362.

17. Haynes, N. E.; Scott, N. R.; Chen, L. C.; Janson, C. A.; Li, J. K.; Lukacs, C. M.; Raikar, A.; Tozzo, E.; Whittard, T.; Brown, N. F.; Cheung, A. W.; ACS Med. Chem. Lett., 2012, 3, 764-768.

18. Mitscher, L. Chem. Rev., 2005, 105, 559-592.

19. Odagiri, T.; Inagaki, H.; Sugimoto, Y.; Nagamochi, M.; Miyauchi, R.; Kuroyanagi, J.; Kitamura, T.; Komoriya S.; Takahashi, H. J. Med. Chem. 2013, 56, 1974-1983.

20. Hirose, T.; Mishio, S.; J. Matsumoto, J.; Minami, S. Chem. Pharm. Bull. 1982, 30, 2399-2409.

21. Sriram, D.; Senthilkumar, P.; Dinakaran, M.; Yogeeswari, P.; China, A.; and Nagaraja, V. J. Med. Chem., 2007, 50, 6232-6239.

22. Grohe, K.; and Heitzer, H. Liebigs Ann. Chem., 1987, 1987, 29-37.

23. Baker, W.; Cai, S.; Dimitroff, M. Fang, L.; Huh, K.; Ryckman, D.; Shang, X.; Shawar, R.; and Therrien, J. J. Med. Chem., 2004, 47, 4693-4709.

24. Horta, P.; Kuş, N.; Henriques, M. S.; Paixão, J. A.; Coelho, L.; Nogueira, F.; O’Neill, P. M.; Fausto, R.; Santos Cristiano, M. L. J. Org. Chem., 2015, 80, 12244-12257. 


\section{Transformation of Ferulic Acid and Vanillin by Isolated Placentas of Capsicum chinense and Capsicum annuum}

Felipe Vázquez-Flota, * Miriam Monforte-González, María de Lourdes Miranda-Ham and Lizbeth A. Castro-Concha

Unidad de Bioquímica y Biología Molecular de Plantas, Centro de Investigación Científica de Yucatán, Calle 43 No. 130, Chuburná 97205, Mérida Yucatán México

* Corresponding author: felipe@cicy.mx

Received November $11^{\text {th }}, 2016$; Accepted January $17^{\text {th }}, 2017$.

\begin{abstract}
Isolated placentas of the highly pungent Capsicum chinense (Habanero pepper), readily transformed ferulic acid and vanillin into capsaicinoids, whereas those from a mild C. annuum cultivar showed a low transformation rate of ferulic acid, in comparison to vanillin. Cell cultures from both species showed low levels of capsaicinoids and exposure to both intermediaries did not increase their amounts. Results suggest that the transformation of ferulic acid to vanillin is a limiting step in capsaicinoids synthesis in $C$. annuum, but not in $C$. chinense and thus, may account for its higher pungency.

Keywords: Capsaicinoids; ferulic acid; peppers; vanillin.
\end{abstract}

\section{Introduction}

Habanero pepper (Capsicum chinense Jacq.) is considered one of the most pungent peppers, reaching values between 100,000 and 600,000 Scoville Heat Units (SHU), equivalent to 7-40 $\mathrm{mg} \mathrm{g}^{-1}$ DW capsaicinoids (CAPs), the active compounds of peppers' typical hot flavor [1]. CAPs are solely synthetized and accumulated in the epidermal cells of the placenta, the tissue holding the seeds inside the fruit [2]. The pathway leading to CAPs synthesis involves shortening of the $\mathrm{C}_{3}$ chain of phenylalanine, through the phenylpropanoid route, to produce an aromatic amine (vanillylamine), which would be condensed with a 10-C acyl unit, derived from a branched amino acid (either leucine or valine; Fig. 1). The last reaction in CAP synthesis involves the formation of an amide bond between the amine group of vanillylamine and the acyl chain, catalyzed by capsaicinoid synthase [1]. Most cDNA's of genes coding the corresponding enzymes involved in CAPs biosynthesis have been isolated [3] and transcriptional profiles during fruit development revealed that most of them are simultaneously accumulated previous to maximal CAPs accumulation [4]. Moreover, regulatory enzymes involved in the synthesis of the required amino acids are coordinately activated with those of CAP synthesis during fruit development $[5,6]$.

Besides CAPs, the phenylpropanoid pathway produces a number of different phenolic compounds. Each intermediary between Phe and vanillylamine (see Fig. 1) might be used as the initial compound of branches leading to different products [7]. In this way, the formation of this amine represents a
Resumen. Tejido placentario de frutos de Capsicum chinense (chile habanero) de alto picor transformó eficientemente ácido ferúlico y vainillina en capsaicinoides. Una variedad de pungencia moderada de $C$. annuum mostró baja transformación de ácido ferúlico, en comparación con la de vainillina. Por su parte, células en suspensión de ambas especies contenían bajos niveles de capsaicinoides y la adición de los precursores no produjo aumentos significativos. Los resultados sugieren que la transformación de ácido ferúlico en vainillina es un paso limitante en la síntesis de capsaicinoides en $C$. annuum, más no así en $C$. chinense, lo que podría explicar su mayor grado de picor.

Palabras clave: ácido ferúlico; capsaicinoides; chiles; vainillina.

committed step towards CAPs synthesis and could function as a regulatory step [1]. In here, we compared the efficiency of Habanero pepper's placentas to transform externally supplied ferulic acid (FA) and vanillin (V) into CAPs to that of a mild $C$. annuum cultivar. These two compounds were selected since both are involved in critical steps of the biosynthetic pathway. The propanoic lateral chain of FA must be cleaved to produce $\mathrm{V}$ (3-methoxybenzaldehyde), which is the direct vanillylamine precursor (Fig. 1). Our results showed that, even though externally supplied $\mathrm{V}$ was equally transformed in both pepper species, C. chinense placentas were more efficient in transforming FA into CAPs than those of $C$. annuum, suggesting that the channeling of these late intermediaries may play a role in defining pepper pungency.

\section{Results and Discussion}

Total CAPs (capsaicin plus dihydrocapsaicin) content in intact placentas from $C$. chinense and C. annuum cultivars used in our experiments were $21.4 \pm 1.63$ and $8.6 \pm 1.31 \mu$ moles $\mathrm{g}^{-1} \mathrm{DW}$, respectively. These values decreased markedly, up to 2.3 and $0.7 \mu$ moles $\mathrm{g}^{-1} \mathrm{DW}$ respectively, upon introduction to in vitro culture due to damage caused to the external surface of the placentas, where CAPS are stored (see Fig 2). However, placentas recovered after their introduction to in vitro culture, remaining metabolically active as it has been shown previously [8]. Two different concentrations of the intermediaries were assayed 


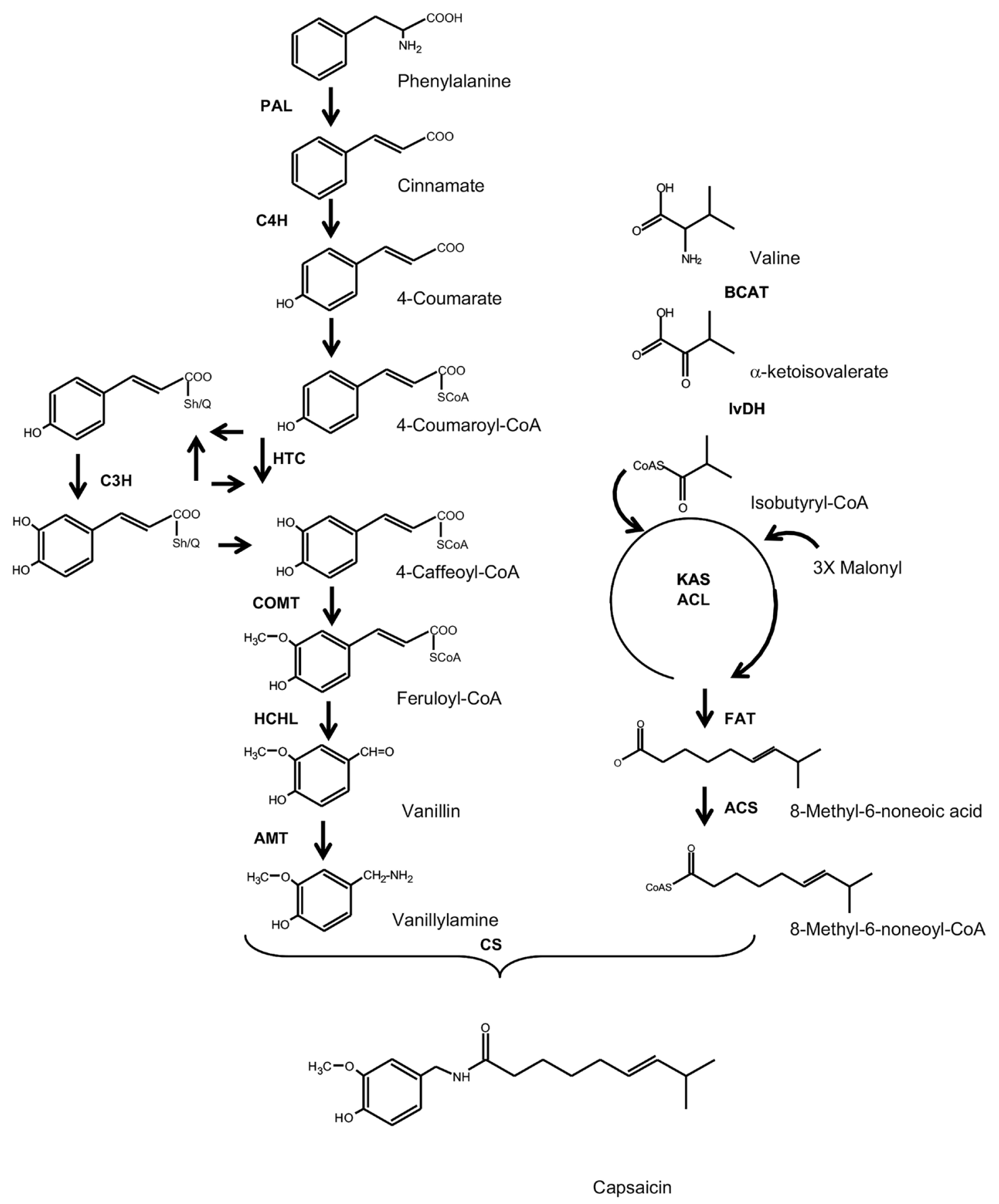

Figure 1. CAP biosynthetic pathway. PAL phenylalanine ammonia lyase; C4H cinnamate 4-hydroxylase; 4CL 4-coumaryl-CoA ligase; HCT hydroxycinnamoyl shikimate/quinate 3-hydroxylase; COMT, caffeic acid methyltransferase; HCHL hydroxycinnamoyl-CoA hydratase/lyase; AMT, vanillin aminotransferase; BCAT branched-chain amino acid transferase; KAS ketoacyl-ACP synthase; ACL acyl carrier protein; FAT acyl-ACP thioesterease; ACS acyl-CoA synthase; CS capsaicinoid synthase. Modified from [1].

(50 and100 $\mu \mathrm{M}$ ) for up to $48 \mathrm{~h}$. Mock water-fed placentas were used as controls. Similar effects were recorded for both intermediaries' concentrations, 50 and $100 \mu \mathrm{M}$, although in a less marked fashion at the lower concentration. Therefore, the results for $100 \mu \mathrm{M}$ are shown only. Moreover, in water-exposed isolated placentas (controls), CAPs levels were maintained with little variation between 2.0 and 4.0 and between 0.6 and $0.8 \mu$ moles $\mathrm{g}^{-1} \mathrm{DW}$ for $C$. chinense and C. annuum, respectively (data not shown). In general, low levels of the analyzed intermediaries (FA and V) were detected in intact placentas from both species (at least two orders of magnitude lower than CAPs; Fig. 2) and this trend was maintained after introducing them 

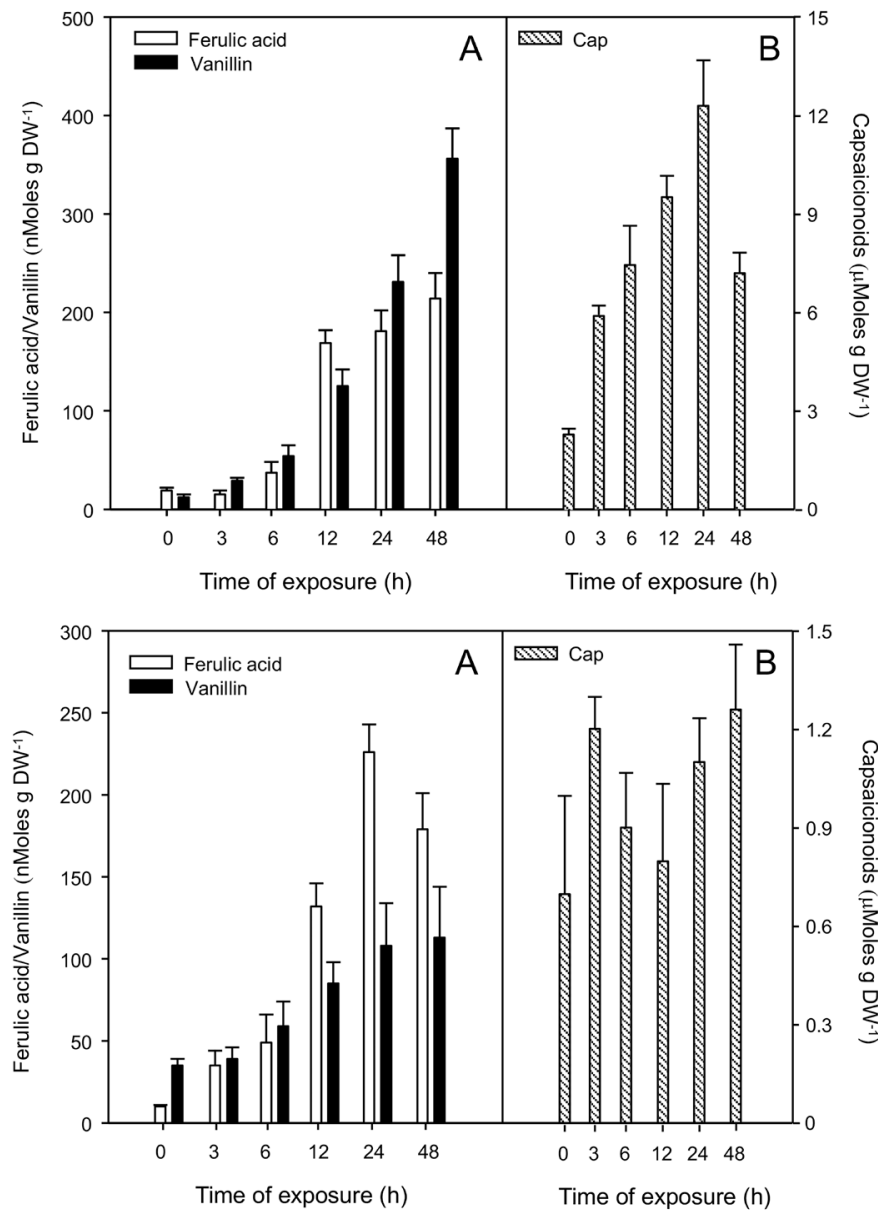

Figure 2. Accumulation of capsaicinoids and biosynthetic intermediaries in C. chinense (A-B) and C. annuum (C-D) isolated placentas exposed to $100 \mu \mathrm{M}$ ferulic acid. Contents of ferulic acid and vanillin in C. chinense (A) and C. annuum (C) placentas. Contents of total capsaicinoids in C. chinense (B) and C. annuum (D) placentas. Average of triplicates with standard deviation.

into culture. The external supply of $100 \mu \mathrm{M}$ FA to isolated placentas had different responses, depending on the Capsicum species employed.

In $C$. chinense placentas, the addition of $\mathrm{FA}$ increased the initial value of $\mathrm{V}$ (Fig. 2A), its direct biosynthetic product, as well as that of FA (Fig. 1). This was more evident after $12 \mathrm{~h}$, but always remaining in the nanomol range (Fig. 2A). This data suggest that $\mathrm{FA}$ was incorporated and transformed into $\mathrm{V}$ under the experimental conditions used. CAPs content showed maximal accumulation (12.3 $\mu$ moles g ${ }^{-1}$ DW) $24 \mathrm{~h}$ after exposure (Fig. 2B). Although those values represented over a five-fold increase of the initial in vitro values $(0 \mathrm{~h}$ in Fig. $1 \mathrm{~B})$, they only accounted for nearly $60 \%$ of those found in intact tissues (21.4 $\pm 1.63 \mu$ moles g $\left.{ }^{-1} \mathrm{DW}\right)$. In isolated placentas of $C$. annuиm, the amounts of FA and V were comparable (Fig. 2C) to those in $C$. chinense. Interestingly CAPs levels slightly increased in response to FA exposure (Fig. 2D) and maximal accumulation in C. annuит (1.4 $\mu$ moles g $\left.\mathrm{g}^{-1} \mathrm{DW}\right)$ occurred $48 \mathrm{~h}$ after exposure. This represented a two-fold increase over the initial in vitro values, which in turn represented a $16 \%$ recovery of the contents of the intact tissues $\left(8.6 \pm 1.31 \mu\right.$ moles $\left.\mathrm{g}^{-1} \mathrm{DW}\right)$. In this way, placentas from both $C$. chinense and $C$. annuum increased FA and $\mathrm{V}$ levels, in response to the addition of FA, suggesting its incorporation to tissues and further utilization. In contrast, those from $C$. annuum showed a limited transformation rate to CAPs (Fig. 2D).

The external supply of $\mathrm{V}$, which is a closer intermediary to CAP formation than FA (Fig. 1), increased V, but not FA contents in C. chinense placentas (Fig. 3A). CAPs levels also increased in the same extent as those observed in placentas exposed to FA, following a similar trend (Fig. 3B). C. annuиm placentas also increased $\mathrm{V}$ contents when exposed to this compound (Fig. 3C). Furthermore, a noticeable increase in the accumulation of CAPs occurred after $12 \mathrm{~h}$ of exposure, reaching values comparable to those of intact placental tissues ( $\mathrm{ca}$. $5 \mu$ moles $\mathrm{g}^{-1} \mathrm{DW}$; Fig. 3D). All together, these data suggest that Habanero pepper (C. chinense) higher pungency, compared to mild $C$. аппиит cultivars, might be related to a higher efficiency in transforming FA into subsequent intermediaries.
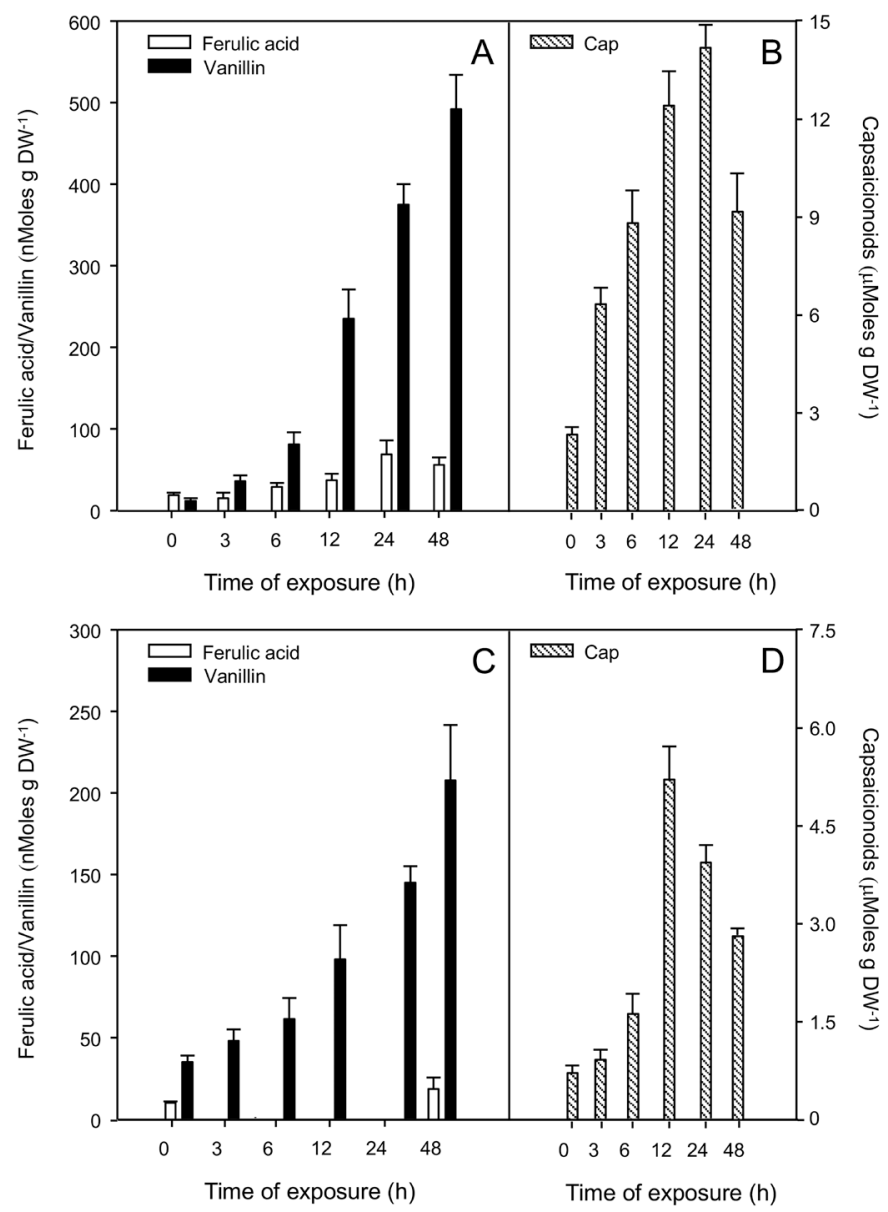

Figure 3. Accumulation of capsaicinoids and biosynthetic intermediaries in C. chinense (A-B) and C. annuum (C-D) isolated placentas exposed to $100 \mu \mathrm{M}$ vanillin. Contents of ferulic acid and vanillin in $C$. chinense (A) and C. annuum (C) placentas. Contents of total capsaicinoids in $C$. chinense $(\mathbf{B})$ and $C$. annuum (D) placentas. Average of triplicates with standard deviation. 
Undifferentiated cell cultures of both $C$. chinense and $C$. annuиm presented a low capacity for CAPs accumulation [9]. In an attempt to promote CAPs formation, cell suspensions were treated in the same way as isolated placentas (Fig. 4 and 5). As expected, the two species showed very low CAPs levels. Interestingly, $C$. chinense cell cultures accumulated a fair amount of $\mathrm{V}$ under normal conditions (around 100 nmoles $\mathrm{g}^{-1}$ DW; Fig. 5A), contrasting to those of $C$. annuum (under 20 nmoles $\mathrm{g}^{-1}$ DW; Fig. 5B). Under the assayed conditions, no increases in CAPs accumulation were recorded in response to the external supply of either FA (Fig. 4A and B) or V (Fig. 5A and B). Nevertheless, FA as well as $\mathrm{V}$ contents, increased in the corresponding treatments (Fig. 4 and 5), suggesting that, to a certain extent, both intermediaries were taken up by the exposed cell cultures. Interestingly, a slight increase in V levels
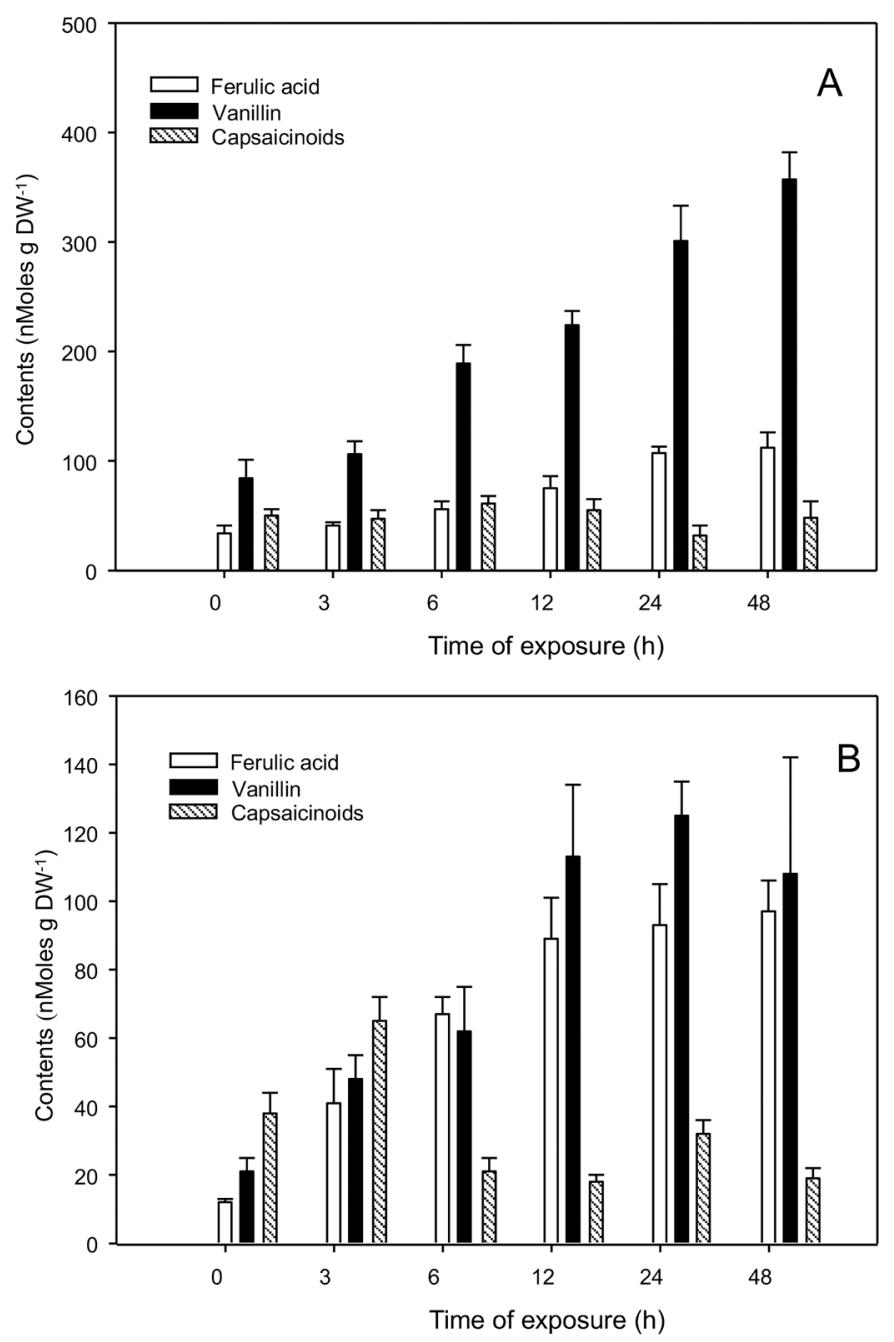

Figure 4. Accumulation of capsaicinoids and biosynthetic intermediaries in C. chinense (A-B) and C. annuum (C-D) cell suspension cultures exposed to $100 \mu \mathrm{M}$ ferulic acid. Contents of ferulic acid and vanillin in C. chinense (A) and C. annuum (C) cultures. Contents of total capsaicinoids in $C$. chinense $(\mathbf{B})$ and $C$. annuum $(\mathbf{D})$ cultures. Average of triplicates with standard deviation. could be observed in the FA-treated C. chinense cells, but not in those from $C$. annuum, indicating that some of the externally supplied FA could have been converted into V, without inducing CAPs accumulation (Fig. 4 and 5).

The capacity to synthetize and accumulate CAPs is exclusively located in epidermal cells of the placental tissue of hot, pungent genotypes of the Capsicum genus [10]. This trait behaves as a single, dominant and epistatic character, controlled by the presence of at least of one functional allele at the Pun 1 loci [11]. No clear correlation between CAP accumulation and the genetic condition at Pun 1 , either homozygous or heterozygous, has been observed [2]. Moreover, most QTL's associated to CAP accumulation can account only to up to a $20 \%$ of the maximal variations [2] and wide differences in CAP amounts have been detected in highly isogenic $C$. апnиит varieties
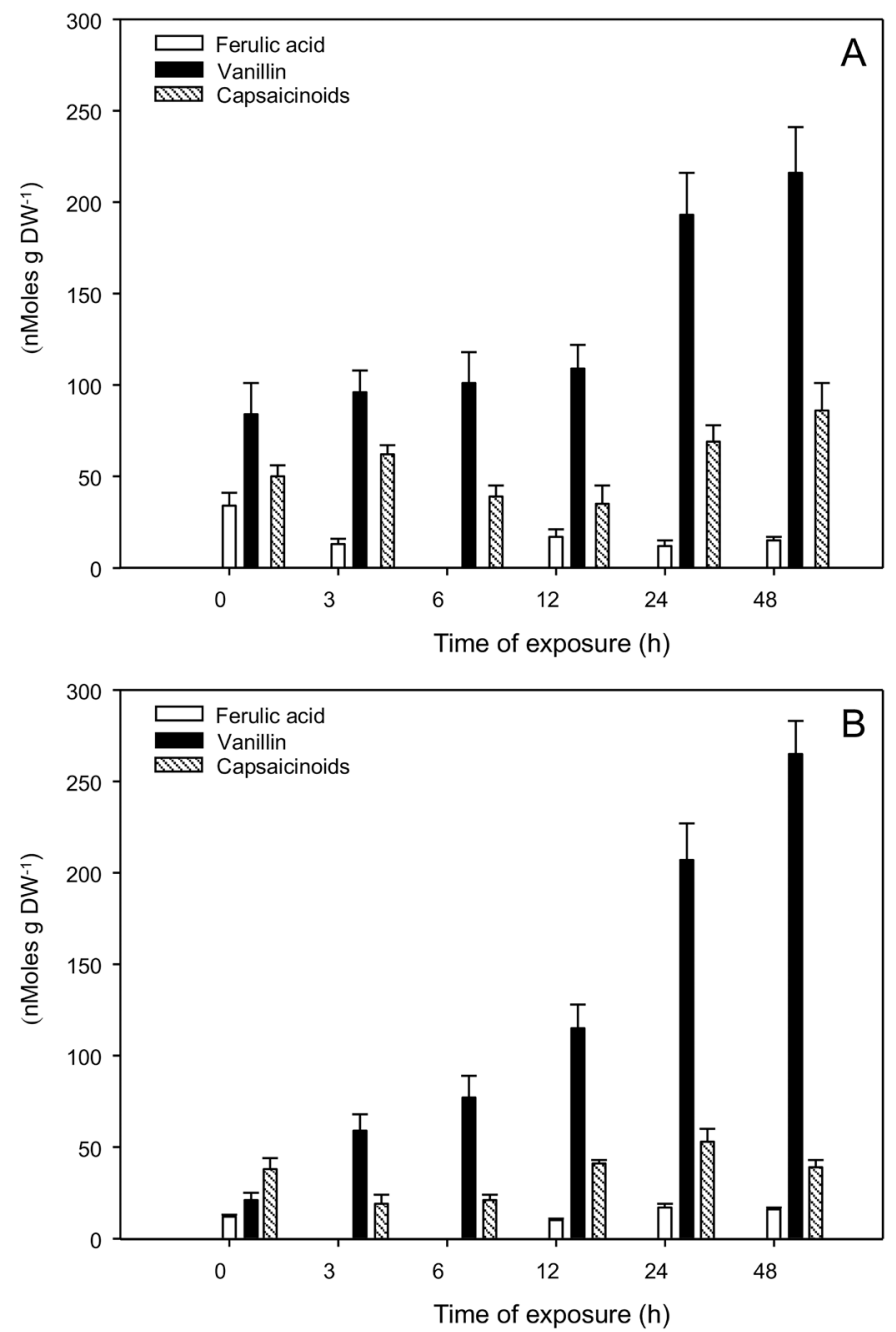

Figure 5. Accumulation of capsaicinoids and biosynthetic intermediaries in C. chinense (A-B) and C. annuum (C-D) cell suspension cultures exposed to $100 \mu \mathrm{M}$ vanillin. Contents of ferulic acid and vanillin in C. chinense (A) and C. annuum (C) cultures. Contents of total capsaicinoids in C. chinense (B) and C. annuum (D) cultures. Average of triplicates with standard deviation. 
cultured under the same conditions [1]. Therefore, as a quantitative trait, pungency is controlled in a complex way, probably involving a multilevel mechanism. In here, we have shown that the availability of late intermediaries, such as FA and V, may affect the final outcome regarding CAPs accumulation. Cinnamic acid, the first product of the phenylpropanoid pathway (Fig. 1), is used in the synthesis of lignin and number of other metabolites. In fact, when cell cultures of $C$. апnиum var. Tampiqueño were presented with an external supply of Phe, cinnamic, coumaric and caffeic acids, CAPs accumulation did not increase, whereas the addition of FA, $\mathrm{V}$ and vanillylamine, the late biosynthetic intermediaries, had an important effect [12]. It should be pointed out that $C$. annuum cell suspensions are able to incorporate externally supplied FA to CAPs $[12,13]$, even though the actual intermediary for CAP synthesis is feruloyl-CoA ester [2]. C. frutescens immobilized placentas were also able to incorporate FA into CAPs [14].

In our experiments, Habanero pepper (C. chinense) placentas incorporated FA into CAPs, and no differences were found when $\mathrm{V}$ was used (Fig. 2 and 3). Conversely, C. annuum placentas were more efficient using $\mathrm{V}$ over FA (Fig. 2 and 3). These data suggest that $C$. chinense placentas readily synthesized feruloyl-CoA ester (C6-C3) from the exogenously supplied acid, which was quickly transformed into the benzoic derivative (C6-C1), channeling the intermediaries to CAPs and some other phenolic products [1]. This higher ability of C. chinense to use FA, in comparison to the mild C. annuum variety, marks a clear difference, and may explain, at least partially, the higher capacity of the Habanero pepper to produce CAPs. The efficient formation of benzoates in Habanero pepper may reduce the possible diversions of the C6-C3 units to other phenylpropanoid compounds, increasing their channeling towards CAPs formation.

It is interesting to notice that cell cultures, which evidently lack tissue organization, only accumulated very low amounts of CAPs (Fig. 4 and 5). Hence, the role of epidermal cell swelling to form blisters, where these compounds are accumulated, has been clearly established [10]. Such blisters remain intact when placental tissues are cultured in vitro, although some damage could be observed, thus explaining the decrease in CAPs levels after manipulation required for initiating the cultures [8].

\section{Experimental}

Biological material and treatments. Placentas were collected from immature pods of $C$. chinense (local landrace Naranja) and C. annuum (local landrace 'Katic'). C. chinense corresponds to a highly pungent genotype, whereas the Katic variety of $C$. annuиm is a mild type of pepper (see Results for a comparison). Peppers were collected once they have attained their final dimensions and taken to the laboratory where they were washed in soapy water, rinsed with tap water and disinfested by subsequent 5 -min incubations in $70 \%$ ethanol and $3 \mathrm{mg} \mathrm{L}^{-1}$ sodium hypochlorite (50\% dilution of commercial bleach). After rinsing the pods in sterile distilled water, the entire placentas were exscinded using scalpel and tweezers and rinsed in sterile water. Square sections of $c a .3 \mathrm{~mm}$ per side were pre-incubated for $1 \mathrm{~h}$ in half strength Murashige and Skoog (MS) medium. After rinsing the tissues with a $10 \%$ dilution of the culture medium, they were kept in $125 \mathrm{~mL}$ Erlenmeyer flasks, containing $25 \mathrm{~mL}$ half strength MS, supplemented with $20 \mathrm{~g} \mathrm{~L}^{-1}$ sucrose [8]. Placentas were cultivated for $12 \mathrm{~h}$ before supplying CAP intermediaries. Ferulic acid (FA) or vanillin (V) (Sigma-Aldrich, St Louis MO) were diluted in water and added to reach final doses of 0 (control, water), 50 and $100 \mu \mathrm{M}$. Tissues were incubated for periods shown in the figures, rinsed with sterile distilled water, frozen in liquid nitrogen and kept at $-80^{\circ} \mathrm{C}$ until analysis. Each treatment was applied in triplicate.

Cell suspension cultures from hypocotyls of $C$. chinense and C. annuum (local landraces Naranja and 'Katic', respectively) were maintained by biweekly subcultures in MS medium as described before [9]. Ten-day cultures were exposed to similar treatments as isolated placentas and kept under constant agitation. Cultures were collected by filtration under vacuum and frozen until analysis.

Analytical procedures. After harvest from the culture flasks, tissues were freeze-dried and one gram was extracted with $12 \mathrm{~mL}$ acetronitrile overnight with gentle shaking (50 $\mathrm{rpm})$ at $60^{\circ} \mathrm{C}$. Extracts were decanted and centrifuged to eliminate tissue debris, dried under reduced pressure, and the residue was then dissolved in $0.5 \mathrm{~mL}$ methanol. Prior to injection (total volume: $20 \mu \mathrm{L}$ ), extracts were centrifuged and filtered through a nylon membrane (pore size: $0.45 \mathrm{~mm}$ ). Capsaicin, dihydrocapsaicin and intermediaries were quantified by DAD-HPLC [15], using an Agilent Technologies liquid chromatographer (Santa Clara CA), Model 1200 with a diode array UV-visible detector coupled to an Agilent LC Chem Station. A Zorbax C18 ODS column ( 4.6 x $250 \mathrm{~mm}, 5 \mathrm{~mm}$ particle size) from Agilent, was used as stationary phase. Solvents used for separation were as follows: solvent $\mathbf{A}, 10 \%$ methanol in water; solvent $\mathbf{B}, 100 \%$ methanol. The separation was carried out isocratically with $70 \% \mathbf{B}$ plus $30 \% \mathbf{A}$, at a flow rate of $1.0 \mathrm{~mL} \mathrm{~min}{ }^{-1}$ for $10 \mathrm{~min}$. The eluant was monitored at $280 \mathrm{~nm}$, and capsaicin (Rt 4.25 min) was completely separated under these conditions from dihydrocapsaicin (Rt $5.75 \mathrm{~min}$ ), ferulic acid (Rt $1.61 \mathrm{~min}$ ), vanillin (Rt $1.87 \mathrm{~min}$ ) and vanillylamine (Rt $2.14 \mathrm{~min}$ ).

\section{Acknowledgments}

Supported by CONACYT. The authors wish to thank Dr. Tomás González-Estrada for providing the pepper seeds and Mr. Fernando Contreras-Martín for growing and maintaining the plants at CICY nursery.

\section{References}

1. Vázquez-Flota, F.; Miranda-Ham, M.L.; Monforte-González, M.; Gutiérrez-Carbajal, G.; Velázquez-García, C.; Nieto-Pelayo, Y. Rev. Fitotec. Mex. 2007, 30, 353-360. 
2. Aza-González, C.; Núñez-Palenius, H.G.; Ochoa-Alejo, N. Plant Cell Rep. 2011, 30, 695-706.

3. Ogawa, K.; Murota, K.; Shimura, H.; Furuya, M.; Togawa, Y.; Matsumura, T.; Masuta, C. BMC Plant Biol. 2015, 15, 93.

4. Martínez-López, L.A.; Ochoa-Alejo, N.; Martínez, O. BMC Genomics 2014, 15, 143.

5. Ancona-Escalante, W.R.; Baas-Espinola, F.M.; Castro-Concha, L.A.; Vázquez-Flota, F.A.; Zamudio-Maya, M.; Miranda-Ham, M.L. Plant Cell Tiss Org Cult. 2013, 113, 565-570.

6. Castro-Concha, L.A.; Baas-Espinola, F.M.; Ancona-Escalante, W.R.; Vázquez-Flota, F.A., Miranda-Ham, M.L. Biol Plant. 2015, 60, 579-584.

7. Vogt, T. Mol Plant. 2010, 3, 2-20.

8. Aldana-Iuit, J.G.; Sauri-Duch, E.; Miranda-Ham, M.L.; Castro-Concha, L.A.; Cuevas-Glory, L.F.; Vázquez-Flota, F.A. BioMed Res Intl. 2015, 2015, ID 7994084.
9. Gutiérrez-Carbajal, M.; Monforte-González, M.; Miranda-Ham, M.L.; Godoy-Hernández, G.; Vázquez-Flota, F. Biol. Plant. 2010 , 54, 430-434.

10. Stewart, C.; Mazourek, M.; Stellari, G.M.; O'Connell, M.; Jahn, M. J Exp Bot. 2007, 58, 979-991.

11. Stewart, C.; Kang, B.C.; Liu, K.; Mazourek, M.; Moore, S.L.; Yoo, E.Y.; Kim, B.D.; Paran, I.; Jahn, M. Plant J. 2005, 42, 675-688.

12. Nuñez-Palenius, H.; Ochoa-Alejo, N. In Vitro Cel Dev Biol-Plant. 2005, 41, 801-805.

13. Kang, S-M.; Jung, H-Y.; Kang, Y-M.; Min, J-Y.; Karigar, C.; Yang, J-K.; Kim, S-W.; Ha, Y-R.; Lee, S-H.; Choi, M-S. J Agric Food Chem. 2005, 53, 3449-3453.

14. Sudhakar Johnson, T.; Ravishankar, G.A.; Venkataraman, LV. Plant Cell Tiss Org Cult. 1996, 4, 117-121.

15. Collins, M.D.; Mayer Wasmund, L.; Bosland, P.W. HortScience. 1995, 30, 137-139. 


\title{
GPU Algorithm for the Scaled Opposite-Spin (SOS) MP2 Energy Evaluation
}

\author{
Luis Ángel Martínez-Martínez ${ }^{1,2}$ and Carlos Amador-Bedolla ${ }^{1 *}$ \\ 1 Facultad de Química, Universidad Nacional Autónoma de México, México D.F. 04510, México \\ * Corresponding author \\ Email address: carlos.amador@unam.mx (Carlos Amador-Bedolla) \\ 2 Current address: Department of Chemistry and Biochemistry, UC San Diego, La Jolla, CA 92093
}

Received September $7^{\text {th }}, 2016$; Accepted February $3^{\text {rd }}, 2017$.

\begin{abstract}
The most computationally intensive part of the SOS-MP2 algorithm for the calculation of the correlation energy [1], as executed in Q-Chem, is implemented for use in a graphical processing unit (GPU). Our approach adds new routines to the library initially developed by Aspuru-Guzik and co-workers [2], aiming at maximization of bandwidth and performance, by taking advantage of the asynchronous CPU-GPU communication capability of modern GPUs. These changes permit an almost six-fold acceleration in the correlation energy calculation of linear alkanes. This was achieved employing a NVIDIA Tesla K40C (Kepler) GPU and the Compute Unified Device Architecture (CUDA).
\end{abstract}

Keywords: GPUs; SOS-MP2; correlation energy; Q-Chem.

\section{Introduction}

The use of accelerators to improve scientific computing performance is not exclusive of recent years. Their early application in scientific code can be traced back to the beginning of the 1980s, when a floating point accelerator was implemented in computers [3]. Recently, Graphic Processing Units (GPUs) have attracted a lot of attention, as can be seen in their extensive use in the high performance computing field.

Early use of GPUs was precluded by their inherent programming complexity, which relied on either OpenGL or DirectX graphic programming languages. This issue limited general purpose computation on GPUs and circumventing this limitation was the motivation for additional efforts [4]. However, the release of NVIDIA's compute unified device architecture (CUDA [5]) provided a high level abstraction model through the incorporation of relatively simple extensions of the standard $\mathrm{C}$ language, which permitted the development of libraries that are useful for common problems in quantum chemistry and solid state physics, such as Fourier transforms (CUFFT [6]) and linear algebra (cuBLAS [7]).

The success of this model is evident: since the CUDA release, a variety of codes have been developed for molecular dynamics applications [8,9], astrophysics simulations [10] and electronic structure methods. Within the last mentioned applications, special efforts have been made concerning the GPU implementation of Hartree-Fock (HF) [11, 12], evaluation of electron repulsion integrals $[13,14]$, density functional theory
Resumen. La parte computacional más intensiva del algoritmo SOSMP2 para el cálculo de la energía de correlación [1], como se lleva a cabo en Q-Chem, es implementada para su uso en unidades de proceso gráfico (GPU). Nuestro método agrega nuevas rutinas a la biblioteca inicialmente desarrollada por Aspuru-Guzik y colaboradores [2], con la intención de maximizar el ancho de banda y la eficacia al aprovechar la comunicación asíncrona GPU-CPU presente en GPUs modernos. Estos cambios permiten una aceleración por un factor de casi seis en el cálculo de la energía de correlación de alcanos lineales. Los resultados se obtuvieron al emplear un GPU NVIDIA Tesla K40C (Kepler) y la Arquitectura de Dispositivo de Cómputo Unificado (CUDA). Palabras Clave: GPUs; SOS-MP2; energía de correlación; Q-Chem.

[15], geometry optimization [16], solvation models [17], resolution of the identity MP2 (RI-MP2) [2, 18], coupled-cluster theory (CC) $[19,20,21]$ and quantum Monte-Carlo [22]. In addition, popular electronic structure codes have adopted hybrid CPU/GPU schemes in order to speedup calculations, for instance GAMESS [23], NWChem [24], TeraChem [25] and Q-Chem [26].

Our work constitutes an additional effort to extend the scope of GPU applications in electronic structure methods. We are interested in the GPU implementation of the so-called scaled opposite-spin second order Møller-Plesset theory (SOSMP2). This is a simplified and economical treatment of electronic correlation energy calculations [1]. In this approach, only the $\alpha-\beta$ component of MP2 energy is calculated and scaled by an empirical factor (which turns out to be 1.3), which yields statistically improved energies and derivative properties over the conventional MP2 method. In addition, the introduction of the Resolution of the Identity (RI) approximation, and a Laplace transform results in an improved method without any fifth order computational steps, in contrast with the original MP2 formulation.

A similar effort has been carried out recently by the introduction of a new SOS-MP2 algorithm by Maurer et al. [27] in which they reduce the scaling by modifying the rate determining step in such a way that it is efficiently evaluated in a GPU without using any GPU-based linear algebra library. However, we believe that our present work is still relevant as it complements the one initiated by Aspuru-Guzik and co-workers [2], 
by adding the non-blocking feature to the set of routines that constitutes the library in development. This has the advantage of reducing the programming effort in the addition of new matrix-multiplications related algorithms, at which the programmer could simply call a single function that automatically carries out the whole process of the non-blocking calculation.

In this work, the main details concerning the GPU implementation of the most computational intensive part of the SOS-MP2 algorithm of Q-Chem, are exposed. This article is organized as follows: in the Theory and Implementation section, the theoretical basis of the SOS-MP2 algorithm are presented and the details of the implementation process and the use of asynchronous calls in CUDA as an option to improve performance are described. In the Results section, the most important results concerning the process of benchmarking are discussed. In the Discussion section we comment on the speedups observed by the use of this GPU implementation. Finally in the Conclusions section we summarize our results.

\section{Theory and Implementation}

\subsection{SOS-MP2 method}

The theoretical basis of the SOS-MP2 method was reported by Head-Gordon and co-workers [1]. In this method, the energy is expressed as a series of matrix multiplications (within a discrete quadrature that involves $\mathrm{Q}$ points), according to:

$$
E_{M P 2}^{O S}=-\sum_{q}^{Q} \sum_{i a}^{\alpha} \sum_{j b}^{\beta} \sum_{K L} B_{i a}^{K} B_{j b}^{K} B_{i a}^{L} B_{j b}^{L}=-\sum_{q}^{Q} \sum_{K L} X_{K L}^{\alpha} X_{K L}^{\beta}
$$

Here, the major computational task consists in the construction of the $\mathbf{X}$ matrix (or matrices, if open shell), which is defined in terms of three-center bielectronic integrals:

$$
\begin{aligned}
& X_{K L}^{\alpha}=\sum_{i a}^{\alpha} B_{i a}^{K} B_{i a}^{L} \\
& B_{i a}^{K}=\sum_{L}^{N}(i a \mid L)(L \mid K)^{-1 / 2}
\end{aligned}
$$

In Eq. $2, B_{i a}^{K}$ results from the RI approximation for the evaluation of four-center integrals, and the scaled orbitals for each quadrature point are given by

$$
\begin{aligned}
& \bar{\phi}_{i}=\phi_{i} w_{q}^{\frac{1}{8}} \exp \left(\frac{1}{2} \varepsilon_{i} t_{q}\right) \\
& \bar{\phi}_{a}=\phi_{a} w_{q}^{\frac{1}{8}} \exp \left(-\frac{1}{2} \varepsilon_{a} t_{q}\right),
\end{aligned}
$$

are a consequence of the numerical integration of

$$
E_{M P 2}^{O S}=-\sum_{i a}^{\alpha} \sum_{j b}^{\beta} \frac{(i a \mid j b)^{2}}{\Delta_{j b}^{i a}},
$$

according to

$$
\begin{aligned}
E_{M P 2}^{O S} & =-\int_{0}^{\infty} d t \sum_{i a}^{\alpha} \sum_{j b}^{\beta}(i a j j b)^{2} \exp \left(-\Delta_{j b}^{i a} t\right) \\
& =-\sum_{q}^{Q} w_{q} \sum_{i a}^{\alpha} \sum_{j b}^{\beta}(i a j j b)^{2} \exp \left(-\Delta_{j b}^{i a} t_{q}\right) \\
& =-\sum_{q}^{Q} \sum_{i a}^{\alpha} \sum_{j b}^{\beta} \overline{(i a j j b)^{2}} .
\end{aligned}
$$

Here, $\Delta_{j b}^{i a}=\varepsilon_{a}+\varepsilon_{b}-\varepsilon_{i}-\varepsilon_{j}$, and $\varepsilon_{i}, \varepsilon_{j}\left(\varepsilon_{a}, \varepsilon_{b}\right)$ are the energies, in the canonical basis, of occupied (virtual) orbitals.

In Q-Chem, for each quadrature point $q$, the $\mathbf{X}$ matrix (or matrices, if open shell) is constructed through the evaluation of Eq. 1. This step is fourth order in molecular size.

In actual Q-Chem SOS-MP2 calculations, the algorithm is timed in the six main steps that are illustrated in Figure 1, namely 1) construction and inversion of the $(P \mid Q)$ matrix, 2) construction of the $(i a \mid P)$ matrix, 3) construction of $B_{i a}^{Q}$, 4) scaling of the $B_{i a}^{Q}$ coefficients, 5) construction of the $\mathbf{X}$ matrices and 6) increment of energy.

It is worth noting that the SOS-MP2 method preserves the size-consistency property given that the OS component of the MP2 energy conserves it, even though, it is possible that due to its approximate nature the size-consistency property might brake down in unexpected situations. Some physical deficiencies are known: firstly, it underestimates the correlation energy in the limit of long separation, due to the fact that the OS components and the same-spin (SS) ones are equal in this limit; and,

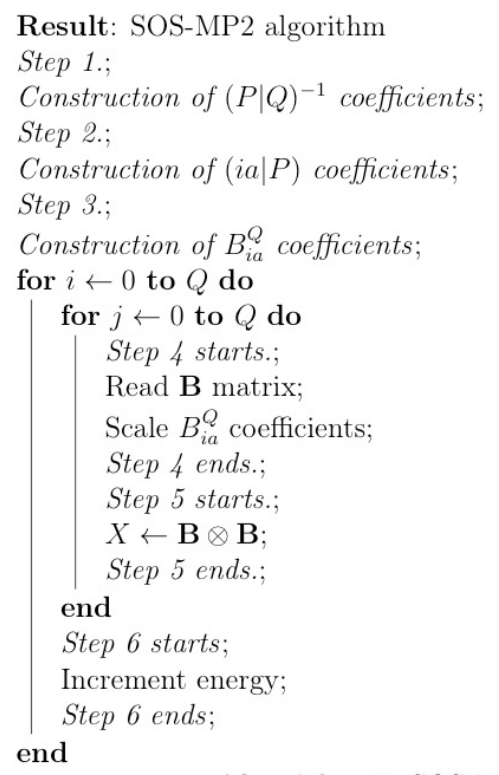

Algorithm 1: SOS-MP2 algorithm

Figure 1. Pseudocode showing the main steps in the SOS-MP2 energy evaluation algorithm in Q-Chem. In this scheme Q denotes the number of points in the numerical quadrature introduced in Equation 7. In actual calculations, $\mathrm{Q}=7$. 
secondly, it can overestimate the correlation energy in systems where the SS component is small [1].

\subsection{Implementation}

During the development of GPU applications, memory optimizations are fundamental to increase performance, thus a second goal is to maximize bandwidth in data transfer. This is commonly done through minimizing CPU-GPU communication, which can be achieved by batching many small transfers into a larger one or enhancing the bandwidth between the host and the device by taking advantage of the non-blocking data transfers capabilities available in modern GPUs [5]. The second option is realized using page-locked (or pinned) memory together with the so-called streams, which are sequences of commands (possibly issued by different host threads) that are executed in the order issued. In contrast with common blocking data transfers, the non-blocking version allows the programmer to issue several memory copies and kernel executions in different streams at a time, so that the operations can be interleaved and overlapped, which translates into a greater occupancy of the device memory (See Fig. 2).

Data parallelism (which focuses on distributing the data across different parallel computing nodes) is common in high performance computing (HPC) oriented to scientific applications, an example of this model is the parallel programming "Single Instruction Multiple Data" of CUDA. Since the onboard memory of GPUs is a finite resource and the amount of data to be processed in HPC fairly exceeds this limit, it is usual to process chunks of the whole data set by the GPU in the most demanding tasks. However, the disadvantage of this scheme is that the number of data transfers that have to be issued is high

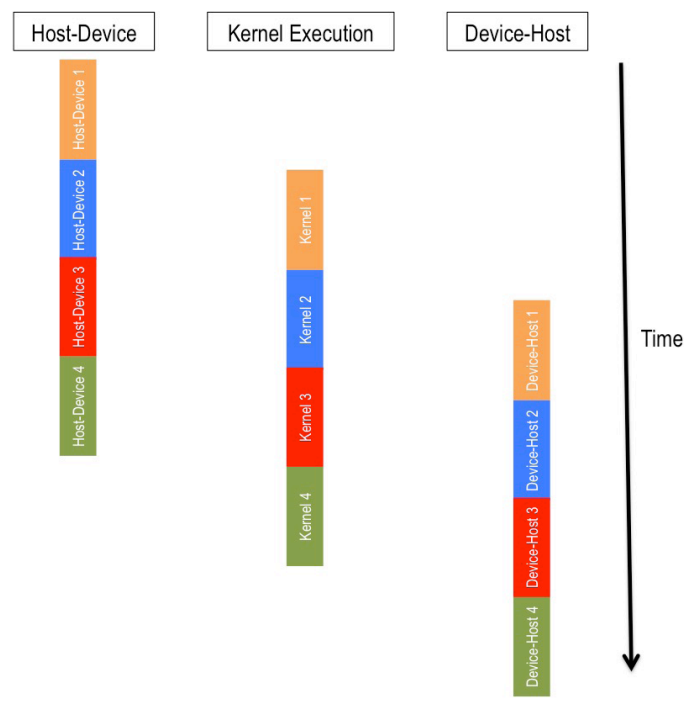

Figure 2. Schematic timeline of asynchronous data transfer in the non-blocking developed version. This approach enables the programmer to overlap communication with computation time by issuing data transfers and kernel executions in different streams (streams are represented with the same color). for large data sets. Although in this case the communication host-device overhead can be reduced, when the algorithm allows it, by reducing data transfers (which can be done by batching several chunks into a larger one and executing the kernel sequentially over segments of the buffer). Nevertheless, in the GPU implementation presented here, we adopted a non-blocking model primarily because it permits to hide memory copy more effectively by overlapping CPU-GPU communication (and viceversa, i. e. GPU-CPU) with kernel execution. Additionally, the bandwidth is enhanced by using pinned memory, and different sets of data can be processed simultaneously when the device has this capability.

In order to show that the most demanding step of the SOSMP2 algorithm corresponds to the one associated with Eq. 1, we carried out a benchmark to analyze the execution times of different steps involved in the SOS-MP2 algorithm, considering linear alkanes and employing the cc-pVDZ/rimp2-cc-pVDZ basis set. The results are summarized in Figure 3.

From these results, it is noted that the wall-time of the energy evaluation is dominated by the fifth step of the algorithm, which correspond to the calculation of the $X_{K L}^{\alpha}$ coefficients. Since it has been shown that this is the most expensive step in the algorithm, we investigated the possibility of achieving a speedup based on the use of Graphical Processing Units by working exclusively on this step.

Firstly, and in order to set goals regarding the speedup that can be achieved parallelizing the section of the code corresponding to the fifth step, we analyzed the trend in the percentage of the total wall-time SOS-MP2 energy evaluation spent in that section as the system size increases. This trend is illustrated in Figure 4.

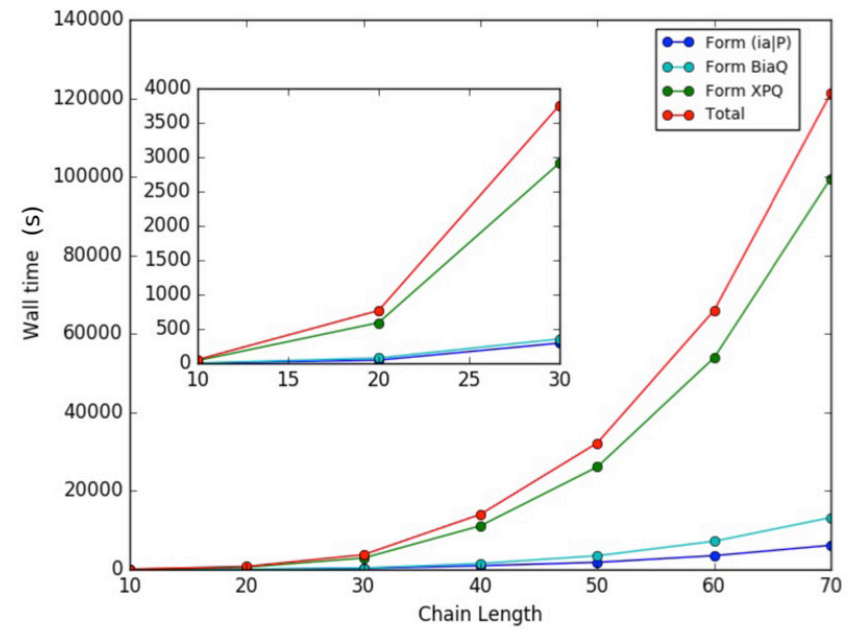

Figure 3. Comparison of the wall-time required by the algorithm steps of the SOS-MP2 energy evaluation, for linear hydrocarbons. The Dunning cc-pVDZ basis and the rimp2-cc-pVDZ auxiliary basis set were used. Only the stages that account for the major percentages of total wall-time are shown: construction of three-center integrals $(i a \mid \mathrm{P})$, construction of $B_{i a}^{Q}$ coefficients, and construction of $X_{K L}^{\alpha}$ coefficients. 


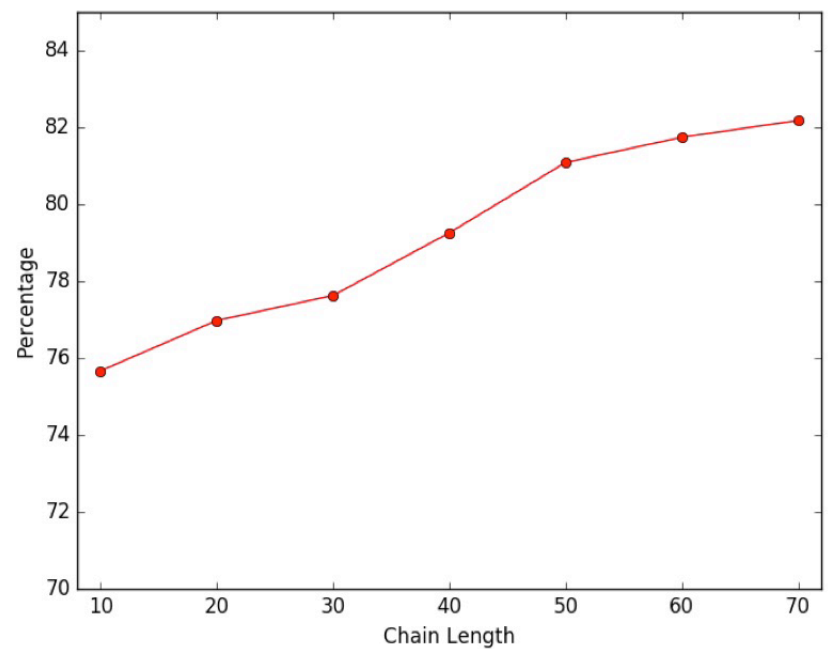

Figure 4. Percentage of total wall-time required by the SOS-MP2 energy evaluation algorithm in the construction of $X_{K L}^{\alpha}$ coefficients in the original Q-Chem code. The systems employed here were linear alkanes of variable chain length, and the basis sets was ccpVDZ/ rimp2-cc-pVDZ.

From these results, we noted that at most, step 5 represents approximately $82 \%$ of elapsed time, and the trend observed seems to prevail for bigger systems. Considering this proportion as parallelizable, and assuming that the $18 \%$ of elapsed time left is sequential, we can set the expected upper-bound speedup by employing Amdahl's law [5]

$$
S=\frac{1}{(1-P)+\frac{P}{N}}
$$

Where $\mathrm{P}$ is the fraction of the total serial execution time taken by the portion of code that can be parallelized and $\mathrm{N}$ is the number of processors where the parallel portion of the code runs. By using Eq. 8, we find that the maximum speedup that can be achieved assuming strong scaling is 5.6.

Equation 1 corresponds to the fifth step of the algorithm. In Q-Chem this is evaluated within a loop over active occupied molecular orbitals. If $N$ is the number of auxiliary orbitals and $v$ the number of active virtual orbitals, first a matrix of size $v \times N$ is read from a temporal file and it is multiplied by its transpose afterwards. Then, this result is augmented into a $N \times N$ matrix $\mathbf{X}$. In order to use the GPU more effectively, we implemented a batch scheme to group $K$ matrices together in such a way that each matrix is processed by an independent stream.

\section{Results}

The most intensive part of the algorithm, as shown above, corresponds to matrix multiplications. In order to assess the performance of this operation with two different CUDA approaches (namely non-blocking and blocking communication versions), we developed two different code toy models. Both models process 100 random matrices, multiplying each of them by its transpose and augmenting the result into a final matrix. The difference between them resides in that one uses asynchronous communication (non-blocking version) and the other uses the common communication routines (blocking version). These test codes were written with CUDA version 6.0 (CUDA driver version 6.0) and were compared with the performance achieved by the Intel ${ }^{\circledR}$ MKL library (Fig. 5). The calculations were carried out on Intel Xeon ${ }^{\circledR}$ processors at $2.40 \mathrm{GHz}$, on a node with the Red Hat Enterprise Linux OS, release 6.5. In the GPU calculations, a Tesla K40C GPU was employed. From the results obtained (Fig. 5), it is worth noting that the reduction in performance due to PCI bus latency is minimal in the case of small matrices, when the non-blocking communication approach is employed (as a result of the computing-communication overlap), and the maximum observed speedup with respect to $\mathrm{CPU}$ timings is approximately $6 \%$ greater that the maximum speedup using blocking communication.

It is worth mentioning that the performance achieved using the MPI model is approximately the same as that achieved when six CPUs are used in conjunction with the use of a GPU as a coprocessor. However, as previous work shows [28], one of the advantages of GPU computing over a multicore approach, is the low energy amount per floating point operation in numerical computations that involve BLAS level 3 operations (matrix-matrix operations). Although a mixed MPI-CUDA scheme can be proposed to take advantage of modern clusters with several GPUs and CPU cores, we preferred to employ the CUDA scheme in the current study, given the availability of a matrix multiplication library in the Q-Chem code, and considering that the new functions can be easily incorporated in a future MPI implementation.

For comparison and exploration purposes, the first approach used to introduce acceleration in the calculations was a simple substitution of the subroutine that carries out the matrix

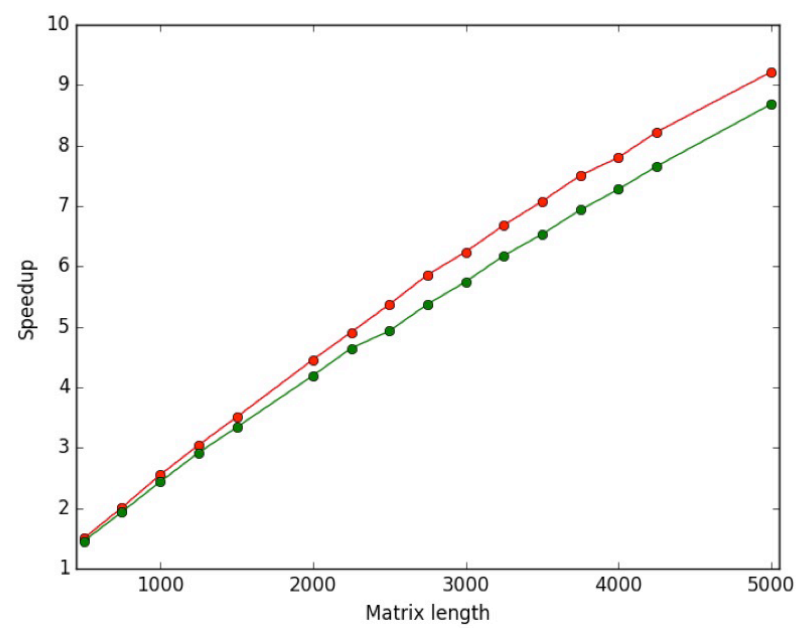

Figure 5. Performance comparison between the two developed CUDA versions for data processing. Speedup=CPU elapsed time/GPU elapsed time. 
multiplication used during the construction of the $X_{K L}^{\alpha}$ matrix, for a subroutine which performs the matrix multiplication employing the NVIDIA cuBLAS library, already implemented in the Q-Chem code. With this simple modification, we observed a significant reduction in the elapsed time associated with the construction of the $X_{K L}^{\alpha}$ matrix, as shown in Figure 6. Results shown in Figure 6 from this approach were obtained with a Tesla M2090 GPU; however, similar results are expected when using more modern GPUs, specially for large systems where the speedup achieved is close to the theoretical limit even when using an old GPU.

To introduce non-blocking communication and with the aim on concurrent execution of matrix multiplications, we proposed a batching scheme in which batches of $\mathrm{K}$ matrices are initialized and then are processed and multiplied by its transpose within a single call of a function, carrying out these tasks in different streams for each matrix. The value of $K$ is set dynamically according to a threshold value which reflects the onboard GPU memory constraint. From the results illustrated in Figure 6, we note that this approach introduces a significant time improvement, with respect to the blocking version. However, this improvement seems to be less effective when the
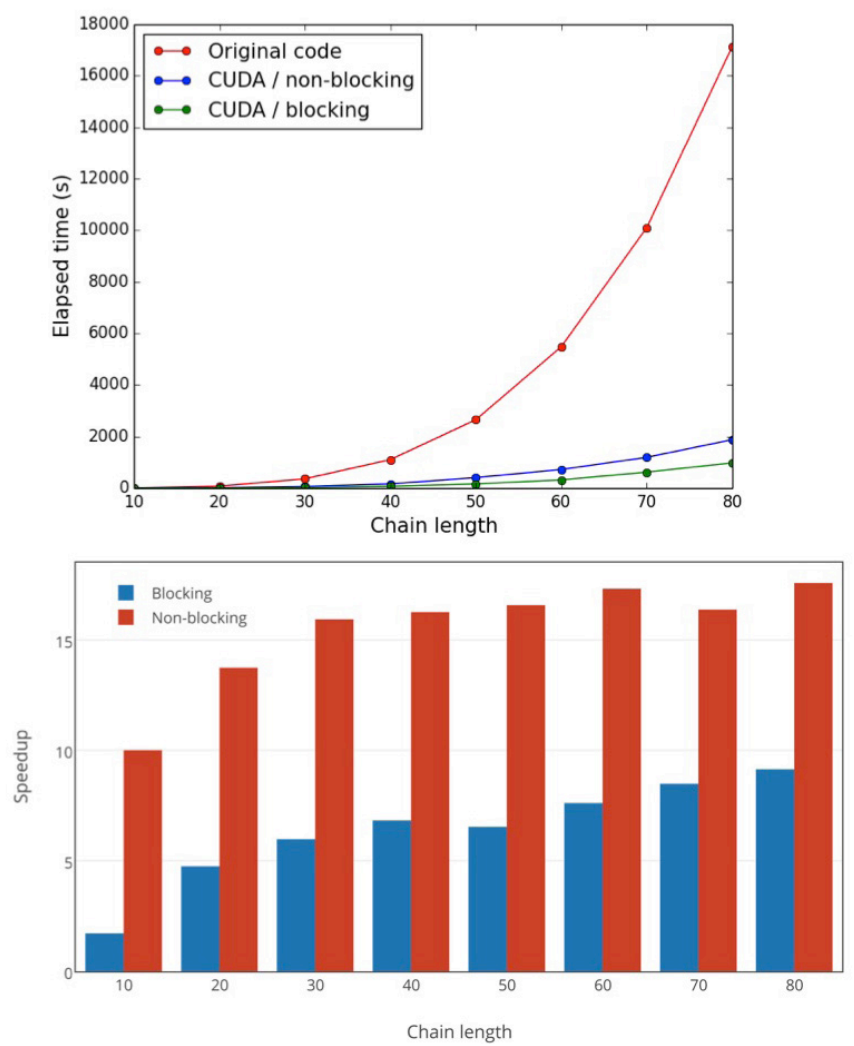

Figure 6. (a)Timing comparison between blocking and non-blocking versions, developed in this work, for the construction of $X_{K L}^{\alpha}$ coefficients in the SOS-MP2 algorithm. The systems employed were linear alkanes and the cc-pVDZ/rimp2-cc-pVDZ basis set. (b) Speedup comparison between the blocking and the non-blocking versions, considering the construction of $X_{K L}^{\alpha}$ coefficients only. These results were obtained using a NVIDIA Tesla M2090 GPU. system size increases, as a consequence of the reduction in the percentage of time invested in communications.

In order to include all these advantages in Q-Chem, a series of subroutines were implemented within the code responsible of the computation of the SOS-MP2 energies. These subroutines accomplish the streams setup, the matrix multiplication using CUBLAS in a concurrent and batched fashion, and the shutting down of the mentioned streams. Furthermore, to take into account the possibility to process big matrices that do not fit the GPU on-board memory, we employed the matrix multiplication library developed by Aspuru-Guzik and co-workers [2] which has the capability to chop big matrices and process the matrix multiplication by pieces. The modified algorithm is described in more detail in Figure 7. The speedups achieved with the implementation of these subroutines are shown in Figure 8. To avoid possible fluctuations in the speedups data due to changes in processing time of the different stages of the calculations, we considered that the only variable in the calculation wall-time was the time spent on step 5, between the GPU and $\mathrm{CPU}$ version. This was done since we noticed that the speedup calculations based on the GPU and CPU raw data gave rise to spurious speedups above the maximum theoretical speedup for the biggest systems.

We tested also for the numerical precision of results obtained on a GPU as coprocessor as they compare to results run on a CPU. As expected for double-precision calculations on both CPU and GPU, results are equal, except for one alkane whose correlation energy is within a margin of less than 0.1 $\mathrm{kcal} / \mathrm{mol}$. Since there was only one case of slight discrepancy between GPU and CPU results, we believe that the error source is not algorithmic but due to an error in data processing.

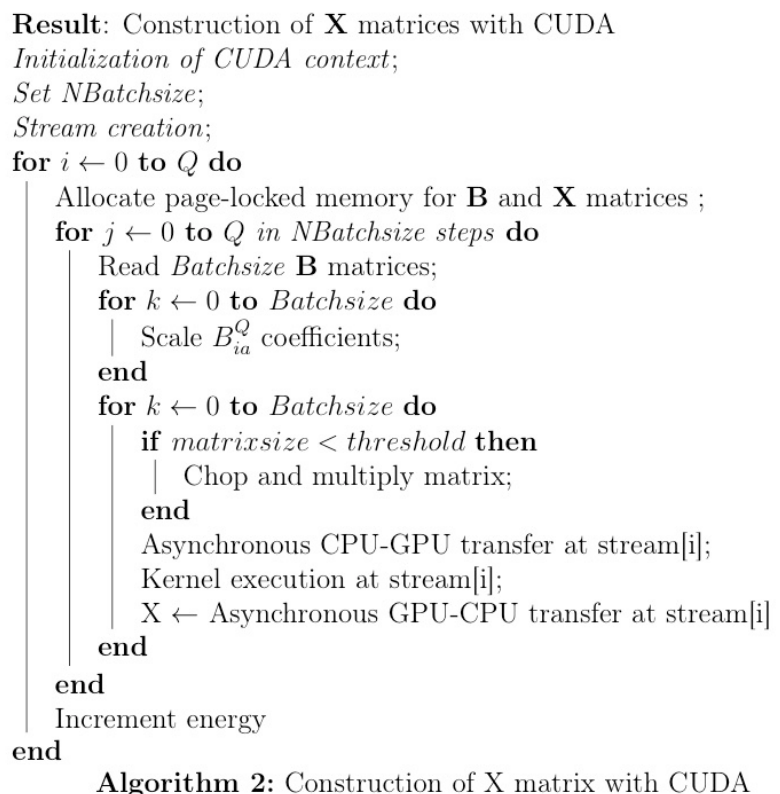

Figure 7. Pseudocode showing the main steps of the proposed algorithm to build the $\mathbf{X}$ matrix in SOS-MP2 calculations. As in Figure 1, $Q$ denotes the number of points in the quadrature for the evaluation of Eq. 7. 


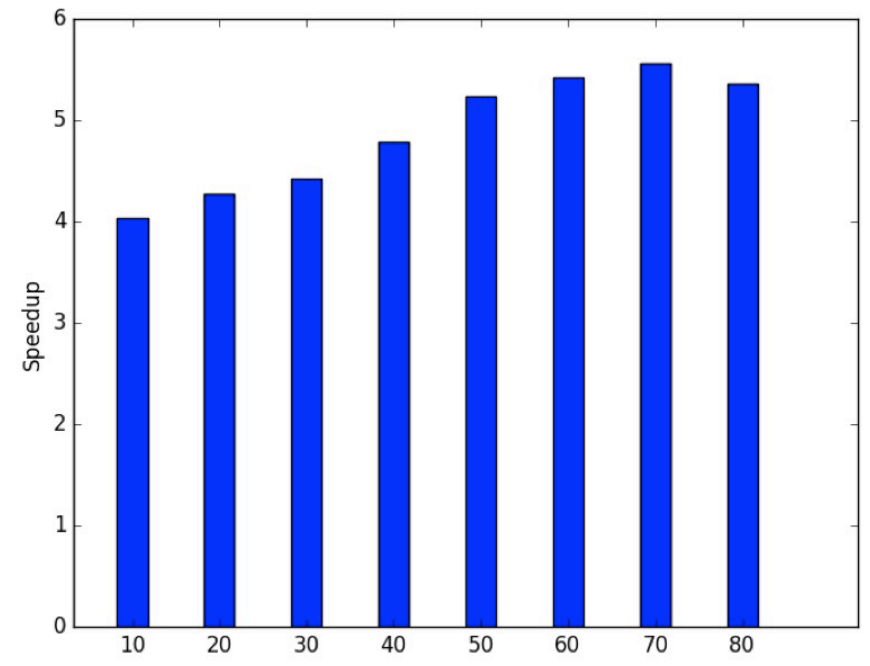

Figure 8. Speedups achieved in the calculation of the correlation energy of SOS-MP2 algorithm after the implementation of the asynchronous CUDA approach described in the main text. The basis set employed is cc-pVDZ.

\section{Discussion}

We have found that the concurrent capacity supported by the majority of GPUs introduces an important enhancement in the execution of the most demanding step of the SOS-MP2 algorithm. On the other hand, given that the speedup in this algorithm has an upper bound of 5.6, the increase in performance compared with the blocking version of the code seems small (see Figure 6), yet it is noteworthy that the speedup achieved constitutes approximately $87 \%$ of that maximum value.

On the other hand, it should be mentioned that the main drawback of this method is that pinned memory is a scarce resource which means that an excessive use of this kind of memory can reduce the overall system performance, that limits its use in very big systems. Unfortunately it is difficult to know how much page-locked memory allocation can interfere with performance, given that it depends on the operative system and other OS applications that compete for resources. However, we think that this problem can be ameliorated with the use of appropriate queue systems that limit the amount of resources allocatable by users, which is the case in modern clusters oriented to HPC.

\section{Conclusions}

In this paper we have evaluated the most computationally intensive part of the SOS-MP2 algorithm for the calculation of the correlation energy with particular application to its execution within the Q-Chem suite. We built on the asynchronous CPU-GPU communication capability of modern GPUs to increase bandwidth and performance. These capabilities were tested on the calculation of a set of linear alkanes from 10 to 80 carbon atoms, where we were able to find an almost three-fold increase in the speed of the computation of the correlation energy. While these results are slightly different depending on the particular GPU employed, considerable speedups are present in all cases. As implementation of the proposed code is simple, use of mixed GPU-CPU schemes like the present one are recommended.

\section{Acknowledgments}

The authors are very thankful to DGTIC and Prof. Jorge Martin del Campo Ramirez for the computational resources provided and computing time and to Yihan Shao for critical reading of the manuscript. L.A.M.M. thanks CONACyT for a master's scholarship (No. 293319) and for the project No. 129343.

\section{References}

1. Jung, Y.; Lochan, R. C.; Dutoi, A. D.; Head-Gordon M., J. Chem. Phys. 2004, 121, 9793-9802.

2. Olivares-Amaya, R.; Watson, M. A.; Edgar, R. G.; Vogt, L.; Shao, Y.; Aspuru-Guzik, A., J. Chem. Theory Comput. 2010, 6, 135-144.

3. Leang, S. S.; Rendell, A. P.; Gordon, M. S., J. Chem. Theory Comput. 2014, 10, 908-912.

4. Götz, A. W.; Wölfle, T.; Walker, R. C., Annu. Rep. Comput. Chem. 2010, 6, 21-35.

5. http://docs.nvidia.com/cuda/cuda-c-programming-guide, NVIDIA CORPORATION, CUDA C Programming Guide, accessed in March, 2017.

6. http://docs.nvidia.com/cuda/cufft, cuFFT CUDA Toolkit Documentation, accessed in March, 2017.

7. http://docs.nvidia.com/cuda/cublas, cuBLAS: CUDA Toolkit Documentation, accessed in March, 2017.

8. Stone, J. E.; Phillips, J. C.; Freddolino, P. L.; Hardy, D. J.; Trabuco, L. G.; Schulten, K., J. Comput. Chem., 2007, 28, 2618-2640.

9. Rovigatti, L.; Sulc, P.; Reguly, I. Z.; Romano, F., J. Comput. Chem., 2015, 36, 1-8.

10. Portegies Zwart, S. F.; Belleman, R. G.; Geldof, P. M., New Astron. 2007, 12, 641-650.

11. Asadchev, A.; Gordon, M. S., J. Chem. Theory Comput., 2012, 8, 4166-4176.

12. Ufimtsev, I. S.; Martinez, T. J., J. Chem. Theory Comput., 2009, 5, 1004-1015.

13. Ufimtsev, I. S.; Martinez, T. J., J. Chem. Theory Comput., 2008, 4, 222-231.

14. Asadchev, A.; Allada, V.; Felder, J.; Bode, B. M.; Gordon, M. S.; Windus, T. L., J. Chem. Theory Comput., 2010, 6, 696-704.

15. Yasuda, K., J. Chem. Theory Comput., 2008, 4, 1230-1236.

16. Ufimtsev, I. S.; Martinez, T. J., J. Chem. Theory Comput., 2009, 5, 2619-2628.

17. Liu, F.; Luehr, N.; Kulik, H. J.; Martínez, T. J., J. Chem. Theory Comput., 2015, 11, 3131-3144.

18. Vogt, L.; Olivares-Amaya, R.; Kermes, S.; Shao, Y.; Amador-Bedolla, C.; Aspuru-Guzik, A., J. Phys. Chem. A, 2008, 112, 2049-2057.

19. DePrince III, A. E.; Hammond, J. R., J. Chem. Theory Comput., 2011, 7 1287-1295. 
20. Ma, W.; S. Krishnamoorthy, S.; Villa, O.; Kowalski, K., J. Chem. Theory Comput., 2011, 7, 1316-1327.

21. Asadchev, A.; Gordon, M. S., J. Chem. Theory Comput., 2013, 9 , 3385-3392.

22. Anderson, A.; Goddard III, W.; Schroder, P., Comput. Phys. Commun., 2007, 177, 298-306.

23. Gordon, M. S.; Schmidt, M. W., in: Theory and Applications of Computational Chemistry: the first forty years, Dykstra, C. E.; Frenking, G.; Kim, K. S.; Scuseria, G. E., Eds., Elsevier, Amsterdam, 2005, 1167-1189.

24. Valiev, M.; Bylaska, E.J.; Govind, N.; Kowalski, K.; Straatsma, T. P.; Van Dam, H. J. J.; Wang, D.; Nieplocha, J.; Apra, E.; Windus, T. L.; De Jong, W. A., Comput. Phys. Commun., 2010, 181, 1477-1489.

25. http://www.petachem.com, PetaChem, accessed in March, 2017

26. Shao Y.; Gan Z.; Epifanovsky E.; Gilbert A.; Wormit M.; Kussmann J.; Lange A.; Behn A.; Deng J.; Feng X.; Ghosh D.; Goldey M.; Horn P.; Jacobson L.; Kaliman I.; Khaliullin R.; Kuś T.; Landau A.; Liu J.; Proynov E.; Rhee Y.; Richard R.; Rohrdanz M.; Steele R.; Sundstrom E.; Woodcock H.; Zimmerman P.; Zuev D.; Albrecht B.; Alguire E.; Austin B.; Beran G.; Bernard Y.; Berquist E.; Brandhorst K.; Bravaya K.; Brown S.; Casanova D.; Chang C.; Chen Y.; Chien S.; Closser K.; Crittenden D.; Diedenhofen M.; DiStasio R.; Do H.; Dutoi A.; Edgar R.; Fatehi S.; Fusti-Molnar L.; Ghysels A.; Golubeva-Zadorozhnaya A.; Gomes
J.; Hanson-Heine M.; Harbach P.; Hauser A.; Hohenstein E.; Holden Z.; Jagau T.; Ji H.; Kaduk B.; Khistyaev K.; Kim J.; Kim J.; King R.; Klunzinger P.; Kosenkov D.; Kowalczyk T.; Krauter C.; Lao K.; Laurent A.; Lawler K.; Levchenko S.; Lin C.; Liu F.; Livshits E.; Lochan R.; Luenser A.; Manohar P.; Manzer S.; Mao S.; Mardirossian N.; Marenich A.; Maurer S.; Mayhall N.; Neuscamman E.; Oana C.; Olivares-Amaya R.; O’Neill D.; Parkhill J.; Perrine T.; Peverati R.; Prociuk A.; Rehn D.; Rosta E.; Russ N.; Sharada S.; Sharma S.; Small D.; Sodt A.; Stein T.; Stück D.; Su Y.; Thom A.; Tsuchimochi T.; Vanovschi V.; Vogt L.; Vydrov O.; Wang T.; Watson M.; Wenzel J.; White A.; Williams C.; Yang J.; Yeganeh S.; Yost S.; You Z.; Zhang I.; Zhang X.; Zhao Y.; Brooks B.; Chan G.; Chipman D.; Cramer C.; Goddard W.; Gordon M.; Hehre W.; Klamt A.; Schaefer H.; Schmidt M.; Sherrill C.; Truhlar D.; Warshel A.; Xu X.; Aspuru-Guzik A.; Baer R.; Bell A.; Besley N.; Chai J.; Dreuw A.; Dunietz B.; Furlani T.; Gwaltney S.; Hsu C.; Jung Y.; Kong J.; Lambrecht D.; Liang W.; Ochsenfeld C.; Rassolov V.; Slipchenko L.; Subotnik J.; Van Voorhis T.; Herbert J.; Krylov A.; Gill P.; Head-Gordon M., Mol. Phys., 2014, 113, 184-215.

27. Maurer, S. A.; Kussman, J.; Ochsenfeld, C., J. Chem. Phys. 2014, 141, 051106.

28. Betkaoui, B.; Thomas, D. B.; Luk, W., in: Proc.-2010 Int. Conf. Field-Programmable Technol. FPT'10, 2010, 94-101. 


\title{
Tonantzitlolone A and other cytotoxic constituents of Sapium macrocarpum (Euphorbiaceae)
}

\author{
Fernando Novillo, ${ }^{1,2}$ Verónica Rosero, ${ }^{1,2}$ María Isabel Chávez, ${ }^{1}$ Simón Hernández-Ortega, ${ }^{1}$ \\ Esteban M. Martínez, ${ }^{3}$ Guillermo Delgado*1 \\ 1 Instituto de Química, Universidad Nacional Autónoma de México. Circuito Exterior, Ciudad Universitaria. Coyoacán 04510. \\ Ciudad de México, México. delgado@unam.mx; tel.: +5255-5622-4446 \\ 2 Facultad de Ciencias Químicas, Universidad Central del Ecuador. Francisco Viteri s/n y Gato Sobral. Quito-Ecuador. \\ 3 Instituto de Biología, Universidad Nacional Autónoma de México, Ciudad Universitaria. Coyoacán 04510. Ciudad de México, \\ México.
}

Received November 30 $0^{\text {th }}, 2016$; Accepted February $13^{\text {th }}, 2017$.

\begin{abstract}
Sapium macrocarpum (Euphorbiaceae) is a tropical tree located mainly in the southern part of Mexico and in Central America, and it is used in the Mayan traditional medicine for the treatment of several skin diseases. The dichloromethane- $\mathrm{MeOH}$ extract of the aerial parts displayed cytotoxic activity against certain cancer cell lines. Lupeol (1), lupenone (2), sitostenone (3), $\beta$-sitosterol (4), stigmasterol (5), sitosteryl $\beta$-D-glucopyranoside (6) and the rare diterpene tonantzitlolone A (7) were characterized from this extract. The structural analysis allowed the ${ }^{1} \mathrm{H}$ NMR reassignments for $\mathrm{H}-12 \alpha$ and $\mathrm{H}-12 \beta$, and for $\mathrm{H}-13 \alpha$ and $\mathrm{H}-13 \beta$ of tonantzitlolone $\mathrm{A}$ (7). The cytotoxic activity of compounds 1-3, 6 and 7 was evaluated against selected cancer cell lines. Compounds 3, 6 and 7 displayed clear activity against K562 (leukemia). This is the first report on the chemical constituents of $S$. macrocarpum, and points out that this species is an additional source of tonantzitlolone A. Compound 7 has only been reported previously from species of the Stillingia, Sebastiania and Sapium genera, which belong to the Hippomaninae subtribe of the family Euphorbiaceae.

Keywords: sitostenone; diterpenes; flexibilane; Euphorbiaceae; NMR reassignments, cytotoxicity.
\end{abstract}

\section{Introduction}

Sapium is a cosmopolitan genus of the Euphorbiaceae plant family which includes 23 accepted names of species, consolidated from 254 former names of synonyms. Several species of this genus have been used in traditional medicine in several parts of the world for treating wounds, snake bites, and skin-related diseases, among other ailments [1,2]. From Sapium species collected in Asia, phenolic compounds were identified as constituents of $S$. insigne [3,4], S. sebiferum [5,6]; phorbol esters were identified as secondary metabolites of $S$. indicum [7,8] and $S$. insigne [3,9]; and the alkaloid bukittinggine and triterpenes were identified as constituents of $S$. baccatum [1012]. Among species collected in the American continent, terpenoids have been isolated from $S$. rigidifolium [13] and $S$. haematospermum [14], and coumarins from S. sebiferum [15].

S. macrocarpum is a tree native mainly to the southern part of Mexico and Central America. It is used in Mayan traditional
Resumen: Sapium macrocarpum (familia Euphorbiaceae) es un árbol localizado en la parte central de México y en Sudamérica, el cual es usado en la medicina tradicional Maya para el tratamiento de diversas enfermedades de la piel. El extracto de diclorometano-metanol de las partes aéreas de esta especie mostró actividad inhibitoria de la proliferación de ciertas células cancerosas humanas. Lupeol (1), lupenona (2), sitostenona (3), $\beta$-sitosterol (4), estigmasterol (5), $\beta$-D-glucopiranósido de sitosterilo (6) y el diterpeno relativamente raro tonantzitlolona A (7) fueron caracterizados de este extracto. El análisis estructural de la tonantzitlolona A (7) permitió la reasignación de las señales de $\mathrm{RMN}{ }^{1} \mathrm{H}$ de $\mathrm{H}-12 \alpha$ y $\mathrm{H}-12 \beta$, y de $\mathrm{H}-13 \alpha$ y $\mathrm{H}-13 \beta$. La actividad citotóxica de los compuestos 1-3, 6 y 7 fue evaluada frente a las líneas celulares cancerosas selectas. Los compuestos 3, 6 y 7 mostraron actividad clara contra K562 (leucemia). Este es el primer reporte sobre los constituyentes químicos de $S$. macrocarpum, encontrando que esta especie constituye una fuente adicional de tonantzitlolona A. El compuesto 7 ha sido aislado de los géneros Stillingia, Sebastiania y Sapium, los cuales pertenecen a la subtribu Hippomaninae de la familia Euphorbiaceae.

Palabras clave: sitostenona; diterpenos; flexibilano; Euphorbiaceae; reasignaciones de RMN, citotoxicidad.

medicine to cure skin infections, and particularly, for treating warts [16]. It has not been chemically analyzed previously, but some phytotoxic compounds have been isolated from an endophytic fungus of this species [17]. Here we report the chemical constituents isolated from an extract of the aerial parts of $S$. macrocarpum, which displayed cytotoxicity in selected tumor cell lines. We identified tonantzitlolone A (7), an uncommon diterpene with a flexibilane skeleton, together with a series of known compounds, and determined their cytotoxicities.

\section{Results and Discussion}

The ${ }^{13} \mathrm{C}$ NMR spectrum of compound $\mathbf{1}$ showed 30 signals which were defined by DEPT experiments. The results showed seven methyl groups, eleven methylenes (one vinylic methylene), six methines (one oxymethine), and six quaternary carbons. The ${ }^{1} \mathrm{H}$ NMR spectrum displayed six singlets for methyl 
groups between $\delta_{\mathrm{H}} 1.03$ and $\delta_{\mathrm{H}} 0.76$, and one methyl group at $\delta_{\mathrm{H}} 1.68$; the latter signal belonged to an isopropenyl fragment, consistent with the presence of the vinylic methylene mentioned above. These NMR data were identical to those reported for lupeol (1) [18], and a direct comparison with an authentic sample confirmed its structure. The less polar fractions of the chromatogram provided a white solid. Its ${ }^{13} \mathrm{C}$ NMR spectrum also displayed 30 signals that included a carbonyl group of a ketone $\left(\delta_{\mathrm{C}} 218.40\right)$ and signals with chemical shifts similar to those for $\mathbf{1}$, but did not show the oxymethine observed for $\mathbf{1}\left(\delta_{\mathrm{C}}\right.$ 79.02). The EIMS showed a molecular ion at $\mathrm{m} / z 424$ in agreement with the molecular formula $\mathrm{C}_{30} \mathrm{H}_{48} \mathrm{O}$. The ${ }^{13} \mathrm{C}$ NMR data and its physical constants were identical to those reported for lupenone (2), confirming its structure [19]. Four structurally related compounds were isolated, whose ${ }^{1} \mathrm{H}$ and ${ }^{13} \mathrm{C}$ NMR data indicated the presence of four tertiary methyls, three secondary methyls and one primary methyl, characteristic for phytosterols. Sitostenone (3) [20,21], $\beta$-sitosterol (4), stigmasterol (5) [22] and $\beta$-sitosteryl $\beta$-D-glucopyranoside (6) [23] were characterized. The identities of these compounds were confirmed by comparing their ${ }^{1} \mathrm{H}$ and ${ }^{13} \mathrm{C}$ NMR data and their physical constants with those published in the literature, and with authentic samples available in our laboratory.

The molecular formula of $\mathrm{C}_{26} \mathrm{H}_{40} \mathrm{O}_{7}$ for metabolite 7, was established from the analysis of its NMR and EIMS data. The ${ }^{13} \mathrm{C}$ NMR spectra (Table 1) exhibited 26 carbon signals, which comprised seven methyl groups (three tertiary, two secondary, one primary and one vinylic), four methylenes, nine methines (four bonded to oxygen, three olefinic, and two aliphatic), and six non-protonated carbons (two carbonyls, one olefinic, one aliphatic, one bonded to oxygen, and one bonded to two oxygens). The presence of a methyl senecioate fragment $\left(\mathrm{C}_{6} \mathrm{H}_{9} \mathrm{O}_{2}\right)$ was established by the ${ }^{13} \mathrm{C}$ and ${ }^{1} \mathrm{H}$ NMR signals assigned (by $\mathrm{HMBC}$ analysis) to an ester carbonyl $\left(\delta_{\mathrm{C}} 166.58\right)$ bonded to the olefinic methine $\left(\delta_{\mathrm{C}} 113.86, \delta_{\mathrm{H}} 5.70\right)$ of a trisubstituted double bond $\left(\delta_{\mathrm{C}} 162.97\right)$, having an ethyl $\left(\delta_{\mathrm{C}} 33.88, \delta_{\mathrm{H}} 2.17 ; \delta_{\mathrm{C}} 11.83\right.$, $\left.\delta_{\mathrm{H}} 1.07\right)$ and a methyl group $\left(\delta_{\mathrm{C}} 18.99, \delta_{\mathrm{H}} 2.16\right)$ as the other substituents. Therefore, this compound was a diterpene with five degrees of unsaturation bonded to a methyl senecioate fragment. The presence of a $\beta, \gamma$-unsaturated- $\alpha$-methyl ketone fragment was deduced from the ${ }^{13} \mathrm{C}$ and ${ }^{1} \mathrm{H}$ NMR signals of a ketone $\left(\delta_{\mathrm{C}} 211.30\right)$ bonded to a methine $\left(\delta_{\mathrm{H}} 3.34\right.$, according to HMBC correlation), which was further linked to a methyl group $\left(\delta_{\mathrm{C}} 16.00, \delta_{\mathrm{H}} 1.12, \mathrm{HMBC}\right.$ and COSY correlations) and to a trans disubstituted double bond $\left(\delta_{\mathrm{C}} 126.81, \delta_{\mathrm{H}} 5.24 ; \delta_{\mathrm{C}} 140.07\right.$, $\delta_{\mathrm{H}}$ 5.86). In addition, the remaining ${ }^{1} \mathrm{H}$ and ${ }^{13} \mathrm{C}$ NMR signals, particularly those for two aliphatic methylenes, three oxymethines, and one hemiketal carbon, were consistent with the presence of a $\delta$-lactol and a tetrahydrofuran in the diterpene skeleton. The NMR data were almost identical to those reported for tonantzitlolone (7, named so after the Aztec goddess Tonantzin, by Dr. X. A. Domínguez), a metabolite previously isolated from Stillingia sanguinolenta, an endemic plant used traditionally in northern Mexico [24]. However, a number of inconsistencies in the reported ${ }^{1} \mathrm{H}$ NMR assignments were detected, particularly those for the $\mathrm{H}-12 \alpha$ and $\mathrm{H}-12 \beta$, and the
$\mathrm{H}-13 \alpha$ and $\mathrm{H}-13 \beta$ [25-27]. The correct assignments are shown in Table 1. These assignments were based on the analysis of the coupling constants between the hydrogens of the tetrahydrofuran ring, which indicated that the observed $J_{12 \alpha, 13 \beta}=0$ (not informed in references 24-27) was in agreement with the $E_{2}$ arrangement of the conformational itinerary of an oxolane ring [28]. Consequently, some reported NOESY correlations should also be corrected according to the new assignments. For instance, the NOESY crosspeak between $\mathrm{H}-14\left(\delta_{\mathrm{H}} 3.77\right)$ and the signal at $\delta_{\mathrm{H}} 2.45$ informed by Lima [26], was not detected, instead, a correlation between $\mathrm{H}-14$ and $\mathrm{H}-13 \beta\left(\delta_{\mathrm{H}} 1.77\right)$ was clearly observed. Some minor inconsistencies were due to the use of different numbering systems for the macrocycle, in addition to the fact that one of the first structures published was later corrected [29]. Selected relevant NOESY correlations are illustrated in the X-ray structure depicted in Figure 1(a), since the conformation determined by X-ray analysis (vide infra) was in agreement with the $\mathrm{H}-\mathrm{H}$ dihedral angles deduced from the $J_{\mathrm{H}-\mathrm{H}}{ }^{1} \mathrm{H}$ NMR coupling constants. Some fragments of this compound were previously synthesized [30], the total synthesis has also been completed [24,31], and its absolute configuration has been established [32], as depicted in formula 7 .

An X-ray analysis of compound 7 confirmed the molecular connectivity and the absolute configuration. In addition, we could identify two intramolecular hydrogen bonds: one between $\mathrm{OH}-9$ and the tetrahydrofuranic oxygen, and the second between $\mathrm{OH}-10$ and the pyranyl oxygen (Figure 1(b)). On the basis of these findings, the structure of $\mathbf{7}$ could be considered to have some rigidity, which further supported the observed ${ }^{1} \mathrm{H}-{ }^{1} \mathrm{H}$ NMR coupling constants, consistent with the conformation of the metabolite in the solid state. The absolute configuration for this compound was the same as that obtained for a compound isolated from Stillingia lineata (Euphorbiaceae) in the search of antichikunguya agents; and thus, compound 7 was renamed by Grondin et al. as tonantzitlolone A [27], since Kirshning et al. previously characterized an structural variant with difference in the ester side chain, named tonantzitlolone B [25].

The inhibitory activities of the extract of Sapium macrocarpum and of compounds 1-3, 6, and 7 were tested against U251, PC-3, K562, HCT-15, MCF-7, and SKLU-1 human tumor cell lines using the protein-binding dye sulforhodamine B (SRB) microculture assay to measure cell growth [33]. The results revealed that the extract (at $50 \mu \mathrm{g} / \mathrm{mL}$ ) and the assayed compounds (at $50 \mu \mathrm{M}$ ) displayed differential activity (Table 2). Lupeol (1) exhibited clear activity against PC-3 cells, and all the natural compounds $(\mathbf{1 - 3}, \mathbf{6}$ and $\mathbf{7})$ were active against the leukemia cell line (K562). $\beta$-Sitosteryl $\beta$-D-glucopyranoside (6) displayed the highest activity in the K562 cell line (77\% of inhibition), consistent with results with other leukemia cells (CEM/ADR5000) [34]. However, evaluations of these pure compounds against other tumor cell lines indicated inhibitory activities below $40 \%$. Sitostenone (3) was previously reported to possess anti-proliferation and anti-tyrosinase activities in melanoma cells [35]. The activities displayed by tonantzitlolone A (7) were similar to those reported previously for tonantzitlolones B-F [36]. Recently, tonantzitlolone A (7) was 

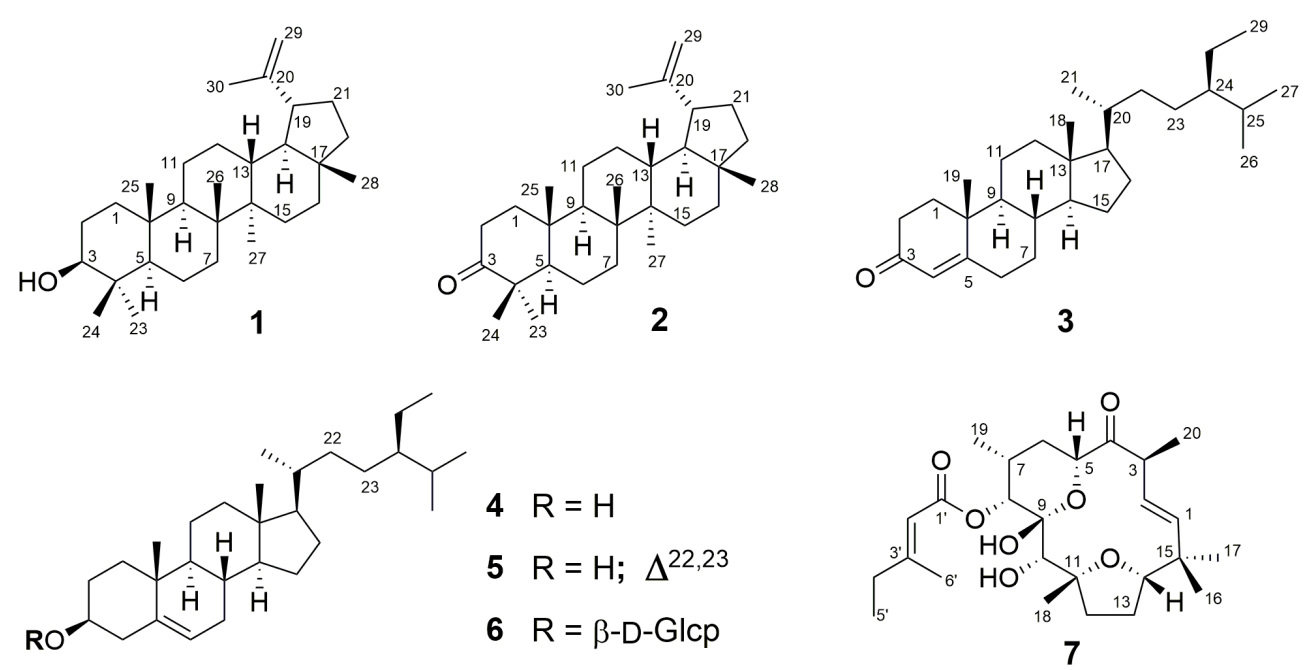

Table 1. ${ }^{1} \mathrm{H}(400 \mathrm{MHz})$ and ${ }^{13} \mathrm{C}$ NMR $(100 \mathrm{MHz})$ data of 7 ( $\delta$ in ppm, $J$ in $\left.\mathrm{Hz}, \mathrm{CDCl}_{3}\right)$

\begin{tabular}{|c|c|c|c|c|c|}
\hline Position & $\delta_{\mathbf{H}}, \mathbf{m}$ & $J(\mathrm{~Hz})$ & $\delta_{\mathbf{C}}$ & NOESY & $\operatorname{HMBC}(\mathrm{H} \rightarrow \mathrm{C})$ \\
\hline 1 & $5.86, \mathrm{~d}$ & $J_{1,2} 15.2$ & 140.07 & $13 \alpha, 3,17$ & $\begin{array}{c}\mathrm{C} 2, \mathrm{C} 3, \mathrm{C} 14, \mathrm{C} 15, \\
\mathrm{C} 17\end{array}$ \\
\hline 2 & $5.24, \mathrm{dd}$ & $J_{1,2} 15.2, J_{2,3} 9.6$ & 126.81 & $16,3,5$ & $\mathrm{C} 3, \mathrm{C} 4, \mathrm{C} 15$ \\
\hline 3 & $3.34, \mathrm{dq}$ & $J_{2,3} 9.6, J_{3,20} 6.8$ & 49.53 & 20 & $\mathrm{C} 1, \mathrm{C} 2, \mathrm{C} 4, \mathrm{C} 20$ \\
\hline 4 & & & 211.30 & & \\
\hline 5 & $4.63, \mathrm{dd}$ & $J_{5,6 \alpha} 12, J_{5,6 \beta} 2.9$ & 74.14 & $6 \beta, 7$ & $\mathrm{C} 4, \mathrm{C} 6$ \\
\hline $6 \alpha$ & 1.39, ddd & $J_{6 \alpha, 6 \beta} 13.5, J_{6 \alpha, 7} 13.0$ & 28.82 & $19,6 \beta$ & $\mathrm{C} 5, \mathrm{C} 8, \mathrm{C} 19$ \\
\hline $6 \beta$ & 1.85, ddd & $J_{6 \beta, 7} 3.2$ & & $19,6 \alpha, 5,7$ & \\
\hline 7 & 2.34, dddq & $J_{7,8} 2.6, J_{7,19} 6.9$ & 29.05 & $5,8,6 \beta, 19$ & C6, C19 \\
\hline 8 & $4.90, \mathrm{~d}$ & $J_{7,8} 2.6$ & 73.17 & $10,7,19$ & $\mathrm{C} 6, \mathrm{C} 19, \mathrm{C} 9$ \\
\hline 9 & & & 97.14 & & \\
\hline 10 & $3.43, \mathrm{~s}$ & & 78.20 & $12 \alpha, 8,18$ & $\mathrm{C} 9, \mathrm{C} 12, \mathrm{C} 18$ \\
\hline 11 & & & 87.65 & & \\
\hline $12 \alpha$ & 2.45 , dd & $\begin{array}{c}J_{12 \alpha, 12 \beta} 12.5, J_{12 \alpha, 13 \alpha} 7.5 \\
J_{12 \alpha, 13 \beta} 0.0\end{array}$ & 37.35 & $12 \beta, 13 \alpha, 10$ & $\mathrm{C} 13, \mathrm{C} 18$ \\
\hline $12 \beta$ & 1.54, ddd & $J_{12 \beta, 13 \beta} 7.5$ & & $18,13 \beta, 12 \alpha$ & \\
\hline $13 \alpha$ & 2.05 , dddd & $\begin{array}{c}J_{13 \alpha, 13 \beta} 12.5, J_{12 \beta, 13 \alpha} 12.5 \\
J_{13 \alpha, 14} 12.5\end{array}$ & 28.06 & $13 \beta, 12 \alpha, 1$ & $\mathrm{C} 12$ \\
\hline $13 \beta$ & 1.77, ddd & $\begin{array}{c}J_{12 \beta, 13 \beta} 7.5, J_{12 \alpha, 13 \beta} 0.0 \\
J_{13 \beta, 14} 5.0\end{array}$ & & $17,12 \beta, 13 \alpha, 14$ & \\
\hline 14 & 3.77 , dd & & 88.89 & $13 \beta, 16,17,12 \beta, 18$ & $\begin{array}{c}\mathrm{C} 1, \mathrm{C} 12, \mathrm{C} 13, \mathrm{C} 16, \\
\mathrm{C} 17\end{array}$ \\
\hline 15 & & & 38.73 & & \\
\hline 16 & $1.14, \mathrm{~s}$ & & 25.09 & $17,14,2, \mathrm{OH}-9$ & $\mathrm{C} 1, \mathrm{C} 14, \mathrm{C} 15, \mathrm{C} 17$ \\
\hline 17 & $0.91, \mathrm{~s}$ & & 25.44 & $16,13 \beta, 14$ & $\mathrm{C} 1, \mathrm{C} 14, \mathrm{C} 15, \mathrm{C} 16$ \\
\hline 18 & $1.38, \mathrm{~s}$ & & 28.11 & $12 \beta, 10$, OH-9 & $\mathrm{C} 10, \mathrm{C} 11, \mathrm{C} 12$ \\
\hline 19 & $0.85, \mathrm{~d}$ & $J_{7,19} 6.9$ & 17.01 & $7,6 \beta, 6 \alpha$ & $\mathrm{C} 6, \mathrm{C} 7, \mathrm{C} 8$ \\
\hline 20 & $1.12, \mathrm{~d}$, & $J_{3,20} 6.8$ & 16.00 & 3 & $\mathrm{C} 2, \mathrm{C} 3, \mathrm{C} 4$ \\
\hline 1 , & - & & 166.58 & - & \\
\hline 2 & $5.70, \mathrm{q}$ & $J_{2,6}, 1.2$ & 113.86 & $5^{\prime}, 4^{\prime}$ & $\mathrm{C} 4^{\prime}, \mathrm{C} 6^{\prime}$ \\
\hline 3 , & - & & 162.97 & - & \\
\hline $4^{\prime}$ & $2.17, \mathrm{q}$ & $J_{4,5}, 7.2$ & 33.88 & 5, & $\mathrm{C} 2^{\prime}, \mathrm{C}^{\prime}$ ', $\mathrm{C} 6^{\prime}$ \\
\hline 5 , & $1.07, \mathrm{t}$ & $J_{4,5}, 7.7$ & 11.83 & 4, & $\mathrm{C} 4$ \\
\hline 6 & $2.16, \mathrm{~d}$ & $J_{2,6}, 1.2$ & 18.99 & 5 & $\mathrm{C} 2^{\prime}, \mathrm{C} 4^{\prime}$ \\
\hline OH-9 & $5.66, \mathrm{~s}$ & & - & $5,10,18$ & $\mathrm{C} 8, \mathrm{C} 9, \mathrm{C} 10$ \\
\hline $\mathrm{OH}-10$ & $3.10, \mathrm{~s}$ & & - & - & - \\
\hline
\end{tabular}


Fernando Novillo et al.

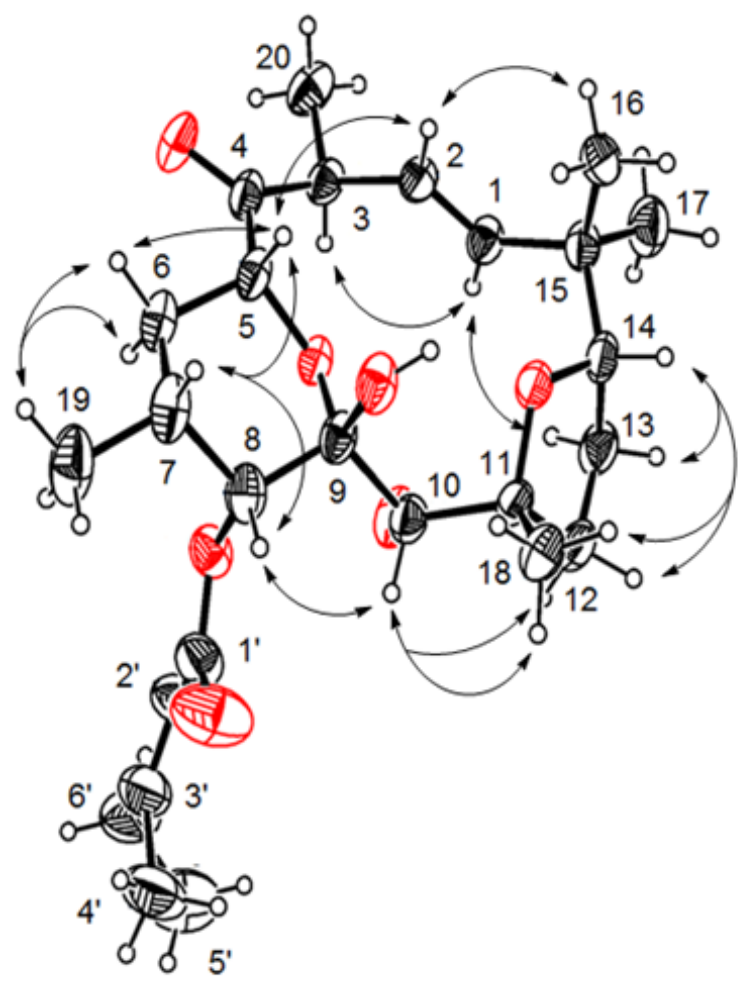

(a)

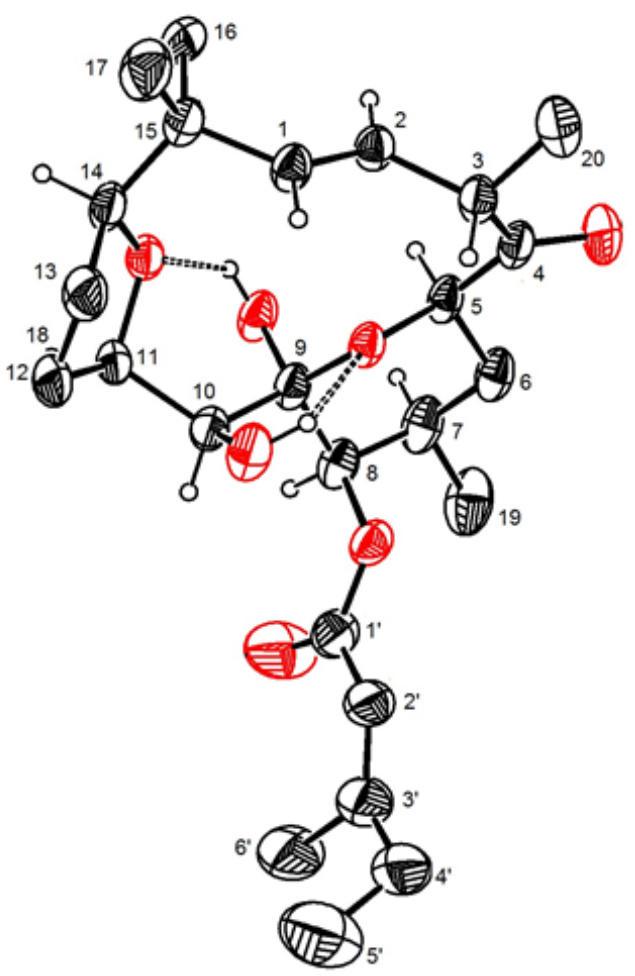

(b)

Figure 1. (a) Selected NOESY correlations of tonantzitlolone A (7) using the drawing derived of the X-ray analysis. (b) X-ray crystal structure of tonantzitlolone A (7) indicating the intramolecular hydrogen bonds (by broken lines).

identified as a potent anti-tumor agent in renal cancer cells as a PKC activator [37], and as a cytostatic compound on tumor cells, inducing monoastral half-spindle formation [38].

Table 2. Cytotoxic activities (\% of inhibition) of the extract and isolated products from $S$. macrocarpum $(50 \mu \mathrm{g} / \mathrm{mL}$ for the extract, $50 \mu \mathrm{M}$ for pure compounds, DMSO as vehicle).

\begin{tabular}{crllccc}
\hline & \multicolumn{6}{c}{ Human tumor cell lines } \\
\hline Sample & U251 & PC-3 & K562 & HCT-15 & MCF-7 & SKLU-1 \\
\hline $\mathrm{CH}_{2} \mathrm{Cl}_{2}-\mathrm{MeOH}$ & 17.5 & 59.8 & 96.5 & 45.3 & 39.5 & 44.6 \\
$(1: 1)$ Extract & & & & & & \\
$\mathbf{1}$ & 27.3 & 50.7 & 48.8 & 10.4 & 22.3 & 13.0 \\
$\mathbf{2}$ & 8.3 & 12.1 & 53.2 & 9.1 & 8.2 & 28.9 \\
$\mathbf{3}$ & 1.5 & 18.4 & 66.1 & 2.8 & 11.6 & 25.9 \\
$\mathbf{6}$ & 11.9 & 32.6 & 77.0 & 12.6 & 2.6 & 27.7 \\
$\mathbf{7}$ & 29.2 & 36.8 & 64.5 & 32.1 & 38.1 & 27.6 \\
Etoposide $^{\mathrm{a}}$ & $91.1^{\mathrm{b}}$ & $51.4^{\mathrm{c}}$ & $60.2^{\mathrm{c}}$ & $80.8^{\mathrm{c}}$ & $56.8^{\mathrm{c}}$ & $81.7^{\mathrm{c}}$ \\
\hline
\end{tabular}

\footnotetext{
${ }^{\text {a }}$ Positive control.

${ }^{\mathrm{b}}$ Concentration at $10 \mu \mathrm{M}$.

${ }^{\mathrm{c}}$ Concentration at $31 \mu \mathrm{M}$.
}

\section{Conclusion}

In our search for bioactive natural products, we found that the extract of S. macrocarpum (collected in the State of Chiapas, Mexico), a plant used in Mayan traditional medicine for the treatment of warts [16], displayed inhibitory activity toward some cancer cell lines. This species had not been previously analyzed, and in the present chemical investigation we characterized compounds 1-7. The ${ }^{1} \mathrm{H}$ NMR analysis of the secondary metabolite 7 allowed the reassignments of the tetrahydrofuran hydrogens. Tonantzitlolone A (7) was previously isolated from a Mexican population of Stillingia sanguinolenta (collected in the State of Nuevo León) [25], and later from Sebastiania macrocarpa (from the Brazilian State of Ceará) [26], and from Stillingia lineata (from La Reunion Island, Indian Ocean, France) [27]. The cytotoxic evaluations of the chemical constituents showed activity and selectivity for some cell lines, although the extract displayed in some cases higher activity, may be due to synergistic interactions. The best cytotoxicities were found with tonantzitlolone A (7) and sitostenone (3), which showed clear activity against a leukemia cell line. The cytotoxicity results for tonantzitlolone A (7) were comparable to those 
found for tonantzitlonones B-F in a previous study [36]. It is interesting to note that flexibilane diterpenes have been characterized from Stillingia, Sebastiania and Sapium species; all these genera belong to the Hippomaninae subtribe, tribe Hippomaneae, subfamily Euphorbioideae of the family Euphorbiaceae [39].

\section{Experimental}

\section{General Experimental Procedures}

Analytical TLC was carried out on precoated silica gel $60 \mathrm{~F}_{254}$ sheets (Merck), and revealed with cerium ammonium sulfate (1\%) in sulfuric acid $2 \mathrm{~N}$. For preparative chromatography (PLC) were used glass plates $(20 \times 20 \mathrm{~cm})$ on precoated silicagel $60 \mathrm{~F}_{254}, 2 \mathrm{~mm}$ (Merck). Column chromatography (CC) was performed using silica gel (230-400 mesh). All solvents were dried and distilled before use. Melting points were determined on a Fisher Johns apparatus (Cole Parmer) and are uncorrected. ${ }^{1} \mathrm{H}(400 \mathrm{MHz}),{ }^{13} \mathrm{C}(100.0 \mathrm{MHz})$, and 2D NMR spectra (in $\mathrm{CDCl}_{3}$ ) were obtained on Bruker Avance III NMR 400 spectrometer. Chemical shifts were expressed in parts per million $(\boldsymbol{\delta})$ relative to TMS as internal standard. EIMS were taken in a JEOL JMS-AX 505 HA. Analysis by X-ray diffraction was performed using a Bruker D8 Venture automatic diffractometer with a CCD area detector at 173(2) K using Helios multilayer mirror $\mathrm{Cu} \mathrm{K} \alpha$ radiation $(\lambda=1.54178 \AA)$.

\section{Plant material, extraction and isolation}

The aerial parts of S. macrocarpum Müll. Arg. was collected in Arriaga district, in the state of Chiapas, Mexico, in 2007. Prof. Esteban M. Martínez identified the plant material and a voucher specimen (39273 Esteban M. Martínez) was deposited in the collection of the National Herbarium (MEXU), Instituto de Biología, UNAM.

Aerial parts of S. macrocarpum (leaves and branches, 1.1 $\mathrm{kg}$ ) were dried, powdered and extracted three times at room temperature with a mixture of $\mathrm{CH}_{2} \mathrm{Cl}_{2}-$ methanol (1:1), and a residue $(41 \mathrm{~g})$ was obtained after evaporating the solvent under reduced pressure. Part of this residue ( $38 \mathrm{~g}$ ) was adsorbed in a 1:1 mixture of celite and silica gel $(30 \mathrm{~g})$ and chromatographed over a silica gel column eluted with hexane-EtOAc mixtures of increasing polarity, yielding 130 eluates which were joined in eight main fractions (A-H), according TLC analyses. Fraction D (124 mg) was subjected to column chromatography over silica gel with hexane-EtOAc gradient system, to give a fraction that was further purified by preparative TLC eluted with a mixture of hexane-EtOAc $(85: 15)$, yielding lupenone $(2,15 \mathrm{mg})$. (Rf 0.69, hexane-EtOAc, 85:15). EIMS $m / z$ (\% rel): $424\left(\mathrm{M}^{+}\right.$, 6), 355 (4), 313 (4), 245 (3), 232 (4), 205 (100), 189 (30), 109 (60), 95 (58), 69 (45), $67(47) .{ }^{1} \mathrm{H}$ NMR $\left(\mathrm{CDCl}_{3}, 400 \mathrm{MHz}\right): \delta$ $4.63(1 \mathrm{H}, \mathrm{d}, J=2.4 \mathrm{~Hz}, \mathrm{H}-29 \mathrm{~b}), 4.50(1 \mathrm{H}, \mathrm{dd}, J=2.6,1.4 \mathrm{~Hz}$, H-29a), 2.35 (1H, m, H-19), 1.62 (3H, s, H-30), 1.50 (1H, s, $\mathrm{H}-2 \mathrm{~b}), 1.37$ (1H, s , H-11), $1.00\left(3 \mathrm{H}, \mathrm{s}, \mathrm{CH}_{3}-26\right), 0.96(6 \mathrm{H}, \mathrm{s}$,
$\left.\mathrm{CH}_{3}-23, \mathrm{CH}_{3}-27\right), 0.81\left(3 \mathrm{H}, \mathrm{s}, \mathrm{CH}_{3}-25\right), 0.79\left(3 \mathrm{H}, \mathrm{s}, \mathrm{CH}_{3}-24\right)$, $0.73\left(3 \mathrm{H}, \mathrm{s}, \mathrm{CH}_{3}-28\right) .{ }^{13} \mathrm{C}$ NMR $\left(\mathrm{CDCl}_{3}, 100 \mathrm{MHz}\right): \delta 218.4$ (C-3), 151.1 (C-20), 109.6 (C-29), 55.1 (C-5), 49.9 (C-9), 48.4 (C-18), 48.1 (C-19), 47.5 (C-4), 43.2 (C-17), 43.1 (C-14), 40.9 (C-8), 40.1 (C-22), 39.8 (C-1), 38.3 (C-13), 37.0 (C-10), 35.7 (C-16), 34.3 (C-2), 33.7 (C-7), 29.9 (C-21), 27.6 (C- 15), 26.8 (C-23), 25.3 (C-12), 21.6 (C-11), 21.2 (C-24), 19.8 (C-6), 19.5 (C-30), 18.2 (C-28), 16.1 (C-25), 15.9 (C-26), 14.6 (C-27).

Fraction E $(170 \mathrm{mg})$ was subjected to silica gel column chromatography using a hexane-EtOAc gradient to afford 92 fractions. Subfractions $E_{27}-E_{30}(20 \mathrm{mg})$ were combined and subjected to preparative TLC to yield tonantzitlolone $\mathrm{A}(7,8 \mathrm{mg})$ as colorless crystals (from acetone). Rf 0.59 (hexane-EtOAc, 85:15), mp 172-173 ${ }^{\circ} \mathrm{C}$. EIMS $m / z$ (\% rel): $464\left(\mathrm{M}^{+}, 25\right), 446$ (29), 364 (12), 350 (10), 180 (25), 126 (25), 97 (100), 69 (65). ${ }^{1} \mathrm{H} \mathrm{NMR}\left(\mathrm{CDCl}_{3}, 400 \mathrm{MHz}\right)$ and ${ }^{13} \mathrm{C} \mathrm{NMR}\left(\mathrm{CDCl}_{3}, 100 \mathrm{MHz}\right)$, see Table 1. Subfractions $\mathrm{E}_{38}-\mathrm{E}_{47}$ were combined and the residue $(29 \mathrm{mg}$ ) was subjected to preparative TLC to yield sitostenone (3, $9 \mathrm{mg})$. Rf 0.42, hexane:EtOAc 85:15. ${ }^{1} \mathrm{H} \mathrm{NMR}\left(\mathrm{CDCl}_{3}\right.$, $400 \mathrm{MHz}$ ): $\delta 5.72(1 \mathrm{H}, \mathrm{s}, \mathrm{H}-4), 1.18(3 \mathrm{H}, \mathrm{s}, \mathrm{H}-19), 0.92(3 \mathrm{H}$, d, $J=8 \mathrm{~Hz}, \mathrm{H}-21), 0.85(3 \mathrm{H}, \mathrm{s}, \mathrm{H}-29), 0.83(3 \mathrm{H}, \mathrm{d}, J=4 \mathrm{~Hz}$, $\mathrm{H}-26), 0.81(3 \mathrm{H}, \mathrm{s}, \mathrm{H}-27), 0.71(3 \mathrm{H}, \mathrm{s}, \mathrm{H}-18) .{ }^{13} \mathrm{C} \mathrm{NMR}\left(\mathrm{CDCl}_{3}\right.$, $100 \mathrm{MHz}): \delta 199.91$ (C-3), 171.9 (C-5), 123.9 (C-4), 56.7 (C-1), 56.2 (C-14), 56.0 (C-17), 54.0 (C-9), 45.97 (C-24), 42.5 (C-13), 39.8 (C-12), 38.8 (C-10), 36.3 (C-20), 35.8 (C-8), 34.1 (C-22), 34.0 (C-7), 33.1 (C-6), 32.2 (C-2), 29.3 (C-23), 28.4 (C-16), 26.2 (C-25), 24.3 (C-15), 23.21 (C-28), 21.2 (C-11), 19.97 (C-27), 19.2 (C-19), 18.9 (C-21), 17.54 (C-26), 12.1 (C-18, C-29).

Fraction F (440 mg) was rechromatographed over silica gel using hexane-EtOAc elution system to obtain 35 eluates. Subfractions $\mathrm{F}_{12}-\mathrm{F}_{18}(64 \mathrm{mg})$ were combined and rechromatographed over silica gel eluting with hexane-EtOAc gradient system, and some fractions were joined and further purified by preparative TLC to yield lupeol $(\mathbf{1}, 19 \mathrm{mg}$ ). Rf 0.40 (hexane-EtOAc, 85:15). From subfractions $\mathrm{F}_{24}-\mathrm{F}_{29}$ was obtained a solid that was characterized by ${ }^{1} \mathrm{H}$ NMR as a 4.3:1 mixture of $\beta$-sitosterol (4) and stigmasterol (5) (72 mg), Rf 0.26, hexane-EtOAc, 85:15. Sequential recrystallizations from acetone-di-isopropyl ether-hexane allowed the purification of the compounds.

From fraction $\mathrm{H}$ was obtained a solid which was purified by repeated recrystallizations from methanol- $\mathrm{CH}_{2} \mathrm{Cl}_{2}$-di-isopropyl ether, affording a white amorphous solid that was characterized by its spectroscopic constants and by chromatographic comparison with an authentic sample as $\beta$-sitosteryl- $\beta$-D-glucopyranoside (6, $38 \mathrm{mg})$. Rf 0.31, $\mathrm{CH}_{2} \mathrm{Cl}_{2}-\mathrm{MeOH}, 9: 1$ [23].

\section{Cytotoxicity Assay}

The cytotoxicity of pure compounds was determined against a number of tumor cells by proliferation assay using the colorimetric method of the sulforhodamine B (SRB, protein binding dye). Cell lines of human tumors, central nervous system (U251), prostate (PC-3), leukemia (K562), colon (HCT-15), breast (MCF-7) and lung (SKLU) were provided by the 
National Cancer Institute (USA). Colored solutions were extracted and optical densities were read on an Ultra Reader of Microplate (Elx 808, Bio-Tek Instruments, Inc.) at wavelength of $515 \mathrm{~nm}$.

\section{X-ray crystallographic analysis of 7}

$\mathrm{X}$-ray structural analysis was achieved on a Bruker D8 Venture automatic diffractometer with a CCD area detector at 173(2) $\mathrm{K}$ using helios multilayer mirror $\mathrm{Cu} \mathrm{K} \alpha$ radiation $(\lambda=$ $1.54178 \AA$ ). The structure was solved by direct methods and refined by full-matrix least-squares on $F^{2}$ using the program SHELXS-2014 (Bruker, 2014). The crystal data can summarized as follows: empirical formula $\mathrm{C}_{26} \mathrm{H}_{40} \mathrm{O}_{7}$; formula weight $464.58 \mathrm{amu}$; colorless prism, crystal system orthorhombic, crystal size $0.278 \times 0.175 \times 0.098 \mathrm{~mm}$, space group $P 2_{1} 2_{1} 2_{1}$, $Z=4, a=10.1588(2) \AA, b=10.2763(2) \AA, c=25.2894(6) \AA$, $\mathrm{V}=2640.08(10) \AA^{3}, D_{\text {calcd }} 1.171 \mathrm{Mg} / \mathrm{m}^{3} ; F(000)=1012 ; \mu=$ $0.681 \mathrm{~m}^{-1} ; 19338$ collected reflections $\left(3.49^{\circ} \leq \boldsymbol{\theta} \leq 68.27^{\circ}\right)$, $-11<=\mathrm{h}<=12,-12<=\mathrm{k}<=7,-30<=1<=30 ; 4827$ independent reflections $\left(R_{\text {int }}=0.0615\right)$; goodness-of-fit on $F^{2}$ is 1.148 , final $R$ indices for $I>2 \sigma(I), R_{1}=0.066, w R_{2}=0.174, R$ indices for all data $R_{1}=0.0777, w R_{2}=0.1873$; refining 331 parameters and 83 restraints; the largest difference peak and hole was 0.359 and -0.232 e. $\AA^{-3}$; completeness to $\boldsymbol{\theta}\left(25.24^{\circ}\right) 99.8 \%$, absorption correction was not applied. Selected crystallographic data are available as supplementary material of this article. Complete crystallographic data were deposited at the CCDC, deposition number 1432773. These data can be obtained free of charge via http://www.ccdc.cam.ac.uk/conts/retrieving.html.

\section{Acknowledgments}

The authors thank SENESCYT (Ecuador), CONACYT (México-288423), UNAM (DGAPA PAPIIT IG 200514), and Programa de Maestría y Doctorado en Ciencias Químicas, UNAM, for financial support. We also thank María Teresa Ramírez Apan, María de los Ángeles Peña González, Rocío Patiño, Antonio Nieto Camacho, Luis Velasco, Javier Pérez Flores (Instituto de Química de la UNAM) for technical assistance. This work is dedicated to Dr. Héctor Rasgado-Flores (Rosalind Franklin University of Medicine and Science, Chicago, USA) on the occasion of his musical composition "Suite of the Elements" written for the International Year of Chemistry (2011).

\section{References}

1. Al Muqarrabun, L.M.R.; Ahmat, N.; Aris, S.R.S. A review of the medicinal uses, phytochemistry and pharmacology of the genus Sapium. J. Ethnopharmacol. 2014, 155, 9-20.

2. The Plant List. http://www.theplantlist.org/ (accessed on 19/11/2016).

3. Devkota, H.P.; Basnet, P.; Yahara, S. Diterpene esters and phenolic compounds from Sapium insigne (Royle) Benth. ex Hook fil. Chem. Pharm. Bull. 2009, 57, 1289-1291.
4. Devkota, H.P.; Basnet, P.; Yahara, S. A new phenolic compound, 4-dehydrochebulic acid-1,6-dimethyl ester from Sapium insigne leaves. J. Nat. Med. 2010, 64, 191-193.

5. Huang, S.; Fujioka, T.; Yoshida, M.; Ishimaru, K. A new chalcone glycoside from Sapium sebiferum. J. Nat. Med. 2007, 61, 339-341.

6. Fu, R.; Zhang, Y.; Guo, Y.; Chen, F. Chemical composition, antioxidant and antimicrobial activity of Chinese tallow tree leaves. Ind. Crops Prod. 2015, 76, 374-377.

7. Taylor, S.E.; Gafur, M.A.; Choudhury, A.K.; Evans, F.J. Nitrogen-containing Phorbol Derivatives of Sapium indicum. Phytochemistry 1981, 20, 2749-2751.

8. Chumkaew, P.; Karalai, C.; Ponglimanont, C.; Chantrapromma, K. Antimycobacterial Activity of Phorbol Esters from the Fruits of Sapium indicum. J. Nat. Prod. 2003, 66, 540-543.

9. Liu, H.B.; Zhang, H.; Yu J.H.; Xu C.H.; Ding, J.; Yue, J.M. Cytotoxic Diterpenoids from Sapium insigne. J. Nat. Prod. 2012, 75, $722-727$.

10. Arbain, D.; Byrne, L.T.; Cannon, J.R.; Patrick, V.A.; White, A.H. (-)-Bukittinggine, the Major Alkaloid of Sapium baccatum. Crystal Structure and Absolute Configuration of Bukittinggine Hydrobromide. Aust. J. Chem. 1990, 43, 185-190.

11. Ahmed, Y.; Sohrab, Md.H.; Al-Reza, S.M.; Tareq, F.S.; Hasan, C.M.; Sattar, M.A. Antimicrobial and cytotoxic constituents from leaves of Sapium baccatum. Food Chem. Toxicol. 2010, 48, 549-552.

12. Al Muqarrabun, L.M.R.; Ahmat, N.; Aris, S.R.S.; Norizan, N.; Shamsulrijal, N.; Yusof, F.Z.M.; Suratman, M.N.; Yusof, M.I.M.; Salim, F. A new triterpenoid from Sapium baccatum (Euphorbiaceae). Nat. Prod. Res. 2014, 28, 1003-1009.

13. Siems, K.; Jakupovic, J.; Castro, V.; Poveda, L. Rigidol, an unusual diterpene from Sapium rigidifolium. Phytochemistry 1993, 33, 1465-1468.

14. Woldemichael, G.M.; Lugo, M.T.G.; Franzblau, S.G.; Wang, Y.; Suarez, E.; Timmermann, B.N. Mycobacterium tuberculosis growth inhibition by constituents of Sapium haematospermum. J. Nat. Prod. 2004, 67, 598-603.

15. Yang, P.; Kinghorn, A.D. Coumarin constituents of the chinese tallow tree (Sapium sebiferum). J. Nat. Prod. 1985, 48, 486-488.

16. Flores, J.S.; Vermont-Ricalde, R. The Secretions and Exudates of Plants Used in Mayan Traditional Medicine. J. Herbs Spices Med. Plants 1996, 4, 53-59.

17. García-Méndez, M. C.; Macías-Ruvalcaba, N. A.; Lappe-Oliveras, P.; Hernández-Ortega, S.; Macías-Ruvalcaba, M. L. Phytotoxic Potential of Secondary Metabolites and Semisynthetic Compounds from Endophytic Fungus Xylaria feejeensis Strain SM3e-1b Isolated from Sapium macrocarpum. J. Agr. Food Chem. 2016, 64, 4255-4263.

18. Burns, D.; Reynolds, W.F.; Buchanan, G.; Reese, P.B.; Enriquez, R.G., Assignment of ${ }^{1} \mathrm{H}$ and ${ }^{13} \mathrm{C}$ spectra and investigation of hindered side-chain rotation in lupeol derivatives. Magn. Reson. Chem. 2000, 38, 488-493.

19. Carpenter, R.C.; Sotheeswaran, S.; Sultanbawa, M.U.S. ${ }^{13}$ CNMR studies of some Lupane and Taraxerane Triterpenes. Org. Magn. Reson. 1980, 14, 462-465.

20. Greca, M. D.; Monaco, P.; Previtera, L. Stigmasterols from Typha latifolia. J. Nat. Prod. 1990, 53, 1430-1435.

21. Prachayasittikul, S.; Suphapong, S.; Worachartcheewan, A.; Lawung, R.; Somsak Ruchirawat, S.; Prachayasittikul, V. Bioactive Metabolites from Spilanthes acmella Murr. Molecules 2009, 14, 850-867.

22. Kongduang, D.; Wungsintaweekul, J.; De-Eknamkul, W. Biosynthesis of $\beta$-sitosterol and stigmasterol proceeds exclusively via the 
mevalonate pathway in cell suspension cultures of Croton stellatopilosus. Tetrahedron Lett. 2008, 49, 4067-4072.

23. Kim, D. K.; Lim, J. P.; Kim, J. W.; Park, H. W.; Eun, J. S. Antitumor and Antiinflammatory Constituents from Celtis sinensis. Arch. Pharm. Res. 2005, 28, 39-43.

24. Jasper, C.; Wittenberg, R.; Quitschalle, M.; Jakupovic, J.; Kirschning, A. Total synthesis and elucidation of the absolute configuration of the diterpene tonantzitlolone. Org. Lett. 2005, 7, 479-482.

25. Dräger, G.; Jeske, F.; Kunst, E.; Lopez, E. G., Sanchez, H. V.; Tsichritzis, F.; Kirschning, A.; Jakupovic, J. Tonantzitlolone and other Diterpenes from Stillingia sanguinolenta. Eur. J. Org. Chem. 2007, 5020-5026.

26. Lima, M.A.A.; Lima, J.Q.; Arriaga, A. M. C.; Andrade-Neto, M.; Santiago, G.M.P.; Bezerra, B.P.; Fereira, Y.S.; Veras, H.N.H.; Braz-Filho, R. Constituintes Químicos de Sebastiania macrocarpa Muell. Arg. (Euphorbiaceae). Quim. Nova 2009, 32, 348-353.

27. Techer, S.; Girard-Valenciennes, E.; Retailleau, P.; Neyts, J.; Guéritte, F.; Leyssen, P.; Litaudon, M.; Smadja, J.; Grondin, I. Tonantzitlolones from Stillingia lineata ssp. lineata as potential inhibitors of chikungunya virus. Phytochemistry Lett. 2015, 12, 313-319.

28. Napolitano, J. G.; Gavín, J. A.; García, C.; Norte, M.; Fernández, J. J.; Hernández Daranas, A. On the Configuration of Five-Membered Rings: A Spin-Spin Coupling Constant Approach. Chem. Eur. J. 2011, 17, 6338-6347.

29. Dräger, G.; Jeske, F.; Kunst, E.; Lopez, E.G.; Sanchez, H.V.; Tsichritzis, F.; Kirschning, A.; Jakupovic, J. Tonantzitlolone and other Diterpenes from Stillingia sanguinolenta. Eur. J. Org. Chem. 2007, 6128.

30. Wittenberg, R.; Beier, C.; Dräger, G.; Jas, G.; Jasper, C.; Monenscheina, H.; Kirschning, A. Towards the total synthesis of tonantzitlolone, preparation of key fragments and the complete carbon backbone. Tetrahedron Lett. 2004, 45, 4457-4460.

31. Jasper, C.; Adibekian, A.; Busch, T.; Quitschalle, M.; Wittenberg, R.; Kirschning, A. Total Synthesis of Cyclic Diterpene
Tonantzitlolone Based on a Highly Stereoselective Substrate-Controlled Aldol Reaction and Ring-Closing Metathesis. Chem. Eur. J. 2006, 12, 8719-8734.

32. Busch, T.; Schuster, H.; Kirschning, A. Determination of the absolute configuration of the diterpene tonantzitlolone B. Tetrahedron Lett. 2008, 49, 5273-5275.

33. Monks, A.; Scudiero, D.; Skehan, P.; Shoemaker, R.; Paull, K.; Vistica, D.; Hose, C.; Langley, J.; Cronise, P.; Vaigro-Wolff, A.; Gray-Goodrich, M.; Campbell, H.; Mayo, J.; Boyd, M. Feasibility of a High-Flux Anticancer Drug Screen Using a Diverse Panel of Cultured Human Tumor Cell Lines. J. Natl. Cancer Inst. 1991, 83, 757-766.

34. El-Readi, M.Z.; Hamdan, D.; Farrag, N.; El-Shazly, A.; Wink, M. Inhibition of P-glycoprotein activity by limonin and other secondary metabolites from Citrus species in human colon and leukaemia cell lines. Eur. J. Pharm. 2010, 626, 139-145.

35. Chu, C.W.; Liu, C.M.; Chung, M.I.; Chen, C.Y. Biofuncional Constituents from Michelia compressa var. lanyuensis with Anti-Melanogenic Properties. Molecules 2015, 20, 12166-12174.

36. Olivon, F.; Palenzuela, H.; Girard-Valenciennes, E.; Neyts, J.; Pannecouque, C.; Roussi, F., Grondin, I.; Leyssen, P.; Litaudon, M.; Antiviral Activity of Flexibilane and Tigliane Diterpenoids from Stillingia lineata. J. Nat. Prod. 2015, 78, 1119-1128.

37. Sourbier, C.; Scroggins, B.T.; Mannes, P.Z.; Liao, P.J.; Siems, K.; Wolf, D.; Beutler, J.A.; Linehan, W.M.; Neckers, L. Tonantzitlolone cytotoxicity toward renal cancer cells is $\mathrm{PKC} \theta$-and HSF1-dependent. Oncotarget 2015, 6, 29963-29974.

38. Pfeffer, T. J.; Sasse, F.; Schmidt, Ch. F.; Lakämper, S.; Kirshning, A.; Scholz, T. The natural diterpene tonantzitlolone A and its synthetic enantiomer inhibit cell proliferation and kinesin-5 function. Eur. J. Med. Chem. 2016, 112, 164-170.

39. Martínez-Gordillo, M.; Jiménez-Ramírez, J.; Cruz-Durán, R.; Juárez-Arriaga, E.; García, R.; Cervantes, A.; Mejía-Hernández, R. Los Géneros de la Familia Euphorbiaceae en México. An. Inst. Biol. UNAM 2002, 73, 155-281. 



\section{Editorial Policy}

The Journal of the Mexican Chemical Society (J. Mex. Chem. Soc.), former Revista de la Sociedad Química de México (Rev. Soc. Quím. Méx.), from 1957 is devoted to facilitate the advancement of our understanding of chemistry. It will publish original contributions of research in all areas of the theory and practice of chemistry in its broadest context, as well as critical reviews in areas where the author has published significant scientific contributions. The language of submission and publication is English. Papers are submitted on the understanding that the subject matter has not been previously published or submitted for publication elsewhere. Editors, referees and authors have to follow and maintain the ethical standards widely accepted in chemical research (see for example: the ACS guidelines or the RSC guidelines). Authors must accept full responsability for the accuracy, content and selection of the data presented. All papers are sent to referees who recommend the Editor on the acceptance or rejection of the script. Referee's names are not disclosed, but their comments are forwarded to the authors. Authors submitting a manuscript do so on the understanding that if it is accepted for publication, copyright of their article is transferred to the Sociedad Química de México.

\section{General Guidelines for Manuscript Preparation}

Authors are encouraged to send contributions in electronic form as MS Word file toeditor.jmcs@gmail.com. On submitting their manuscripts, authors are encouraged to supply a cover letter suggesting the names and e-mail addresses of at least four potential referees. The cover letter may include the name of a member of the Editorial Board or the Advisory Editorial Board for manuscript assignment. If no acknowledgement receipt has been received after five working days, authors should contact the editor. All pages of the manuscript should be consecutively numbered. Accepted manuscripts should be resubmitted as MS Word file and separate files of the artwork in .TIFF, .JPG or PostScript formats. Black and white photographs must be scanned with a resolution of no less than $600 \mathrm{dpi}$. It is advisable to provide illustrations (figures, schemes, charts, tables, graphics) in the actual size at which they should appear in the printed version and should be designed to fit in one- or twocolumns format. The journal will publish a graphical abstract which includes the title and the author list, and illustrates the content of the paper in a pictorial form. The graphical abstract is limited to $9.0 \mathrm{~cm}$ wide and $4.5 \mathrm{~cm}$ tall, and authors may examine J. Mex. Chem. Soc. 2005, 49, 55-60 (joint issue with the J. Braz. Chem. Soc.) for appropriate examples. Page 1 should contain the article title (brief and informative), author(s) name(s) (first names and surnames, do not use initials for names, the corresponding author(s) should be indicated with an asterisk, use superscripts to indicate different addresses), complete affiliation(s) (the corresponding author's mailing address, phone number, fax number or e-mail address should be included). Page 2 should contain an abstract (both in English and Spanish, about 80 words) and five to eight key words in both languages.

A suggested organization of an article is: Introduction, Results and Discussion, Experimental, Acknowledgements and References. All the sections of the paper must be presented with the utmost conciseness and clarity. The measurements and data should be given in the International Units System (SI), and abbreviations should be used consistently through the text. Avoid reiteration of information. The discussion should present only the new results and relate them to existing knowledge in the field, and a paragraph summarizing the principal conclusion of the article is recommended. Complete X-ray data should be deposited at the Cambridge Crystallographic Data Centre (http://www.ccdc.cam.ac.uk/products/csd/faqs/\#deposition_scheme) or to Fachinformationszentrum Karlsruhe (FIZ), which will provide codes for each data set, which are then cited in a reference in the manuscript. If a representation of the crystal structure is to be included, it should be accompanied by pertinent crystallographic data, method of collection, and methods of structure solution and refinement. The experimental section must contain all the information necessary for reproducibility. Convincing evidence to confirm the identity of a compound should be provided. All new compounds should be fully characterized with relevant and detailed spectroscopic data. For physical and spectroscopic data, the following general style must be used:

(3S)-7-Hydroxy-2', 3',4',5',8-pentamethoxyisoflavan (1). Amorphous powder: $\mathrm{mp} 125-126^{\circ} \mathrm{C} ;[\alpha]_{\mathrm{D}}+3.12(\mathrm{c} 0.320, \mathrm{MeOH})$; UV $(\mathrm{MeOH}) \lambda_{\max }$

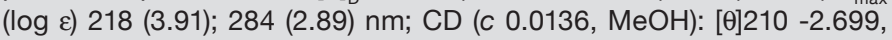
$[\theta]_{226} 0.4130,[\theta]_{256}-0.8567,[\theta]_{265.5}-0.6865 ; \mathrm{IR}\left(\mathrm{CHCl}_{3}\right) v_{\max } 3530,2939$, 2840, 1603, 1494, 1193, $1040 \mathrm{~cm}^{-1} ;{ }^{1} \mathrm{H} \mathrm{NMR}\left(\mathrm{CDCl}_{3}, 500 \mathrm{MHz}\right) \delta 6.72$ $\left(1 \mathrm{H}, \mathrm{dd}, J_{5,6}=8.5, J_{4 \alpha, 5}=1.0 \mathrm{~Hz}, \mathrm{H}-5\right), 6.53\left(1 \mathrm{H}, \mathrm{dd}, \mathrm{J}_{5,6}=8.5 \mathrm{~Hz}, \mathrm{H}-6\right)$, $6.40\left(1 \mathrm{H}, \mathrm{s}, \mathrm{H}-6^{\prime}\right), 5.80(1 \mathrm{H}, \mathrm{brs}, \mathrm{OH}), 4.39\left(1 \mathrm{H}, \mathrm{ddd}, \mathrm{J}_{2 \beta, 2 \alpha}=10.5, J_{2 \beta, 3 \beta}\right.$ $\left.=3.5, J_{2 \beta, 4 \beta}=1.0 \mathrm{~Hz}, \mathrm{H}-2 \beta\right), 4.05\left(1 \mathrm{H}, \mathrm{dd}, J_{2 \beta, 2 \alpha}=J_{2 \alpha, 3 \beta} 10.5, \mathrm{~Hz}, \mathrm{H}-2 \alpha\right)$, $3.95\left(3 \mathrm{H}, \mathrm{s}, \mathrm{CH}_{3} \mathrm{O}-\mathrm{C}-3^{\prime}\right), 3.92\left(3 \mathrm{H}, \mathrm{s}, \mathrm{CH}_{3} \mathrm{O}-\mathrm{C}-8\right), 3.89\left(3 \mathrm{H}, \mathrm{s}, \mathrm{CH}_{3} \mathrm{O}-\mathrm{C}-\right.$ 4'), $3.83\left(3 \mathrm{H}, \mathrm{s}, \mathrm{CH}_{3} \mathrm{O}-\mathrm{C}-2\right.$ '), $3.79\left(3 \mathrm{H}, \mathrm{s}, \mathrm{CH}_{3} \mathrm{O}-\mathrm{C}-5\right.$ '), 3.61 (1H, dddd, $J$ $=10.5,3.5,5.5,10.5 \mathrm{~Hz}, \mathrm{H}-3), 2.96\left(1 \mathrm{H}\right.$, ddd, $J_{4 \alpha, 4 \beta}=16.0, J_{4 \alpha, 3 \beta}=10.5$, $\left.J_{4 \alpha, 5}=1.0 \mathrm{~Hz}, \mathrm{H}-4 \alpha\right), 2.90\left(1 \mathrm{H}, \mathrm{ddd}, J=16.0, J_{3 \beta, 4 \beta}=5.5, J_{2 \beta, 4 \beta}=1.0 \mathrm{~Hz}\right.$, $\mathrm{H}-4 \beta) ;{ }^{13} \mathrm{C} \mathrm{NMR}\left(\mathrm{CDCl}_{3}, 125 \mathrm{MHz}\right.$, assignments by APT and HMQC) $\delta$ 149.67 (C-5'), 147.60 (C-7), 147.15 (C-3'), 147.12 (C-8a), 145.50 (C2'), 141.95 (C-4'), 134.80 (C-8), 128.90 (C-1'), 124.20 (C-5), 115.00 (C4a), 107.10 (C-6), 70.28 (C-2), $61.89\left(\mathrm{OCH}_{3}-\mathrm{C}-4^{\prime}\right), 61.51\left(\mathrm{OCH}_{3}-\mathrm{C}-2^{\prime}\right)$, $61.00\left(\mathrm{OCH}_{3}-\mathrm{C}-3^{\prime}\right), 60.90\left(\mathrm{OCH}_{3}-\mathrm{C}-8\right), 56.25\left(\mathrm{OCH}_{3}-\mathrm{C}-5\right), 31.85(\mathrm{C}-3)$,

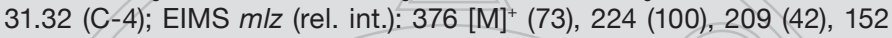
(16), 151 (38), 121 (14). Anal. C 63.65\%, $\mathrm{H} 6.68 \%$, calcd for $\mathrm{C}_{20} \mathrm{H}_{24} \mathrm{O}_{7}$, C $63.82 \%$, H $6.43 \%$.

For computational results, pertinent data such as force field parameters and equations should be included, to allow readers to repeat and reproduce the calculations. References to the literature should be noted in the text in order of appearance with numerals between brackets and should coincide with entries in the References section. It is not recommended to include bibliography of difficult access (theses, abstracts of meetings, unpublished material, technical reports, work in press, etc.) as references. The style and punctuation should rigorously conform to the format in the following examples:

1. Kingsbury, J. S.; Corey, E. J. J. Am. Chem. Soc. 2005, 127, $13813-$ 13815

2. Vanden Berghe, D. A.; Vlietinck, A. J., in: Methods in Plant Biochemistry, Vol. 6, Hostettmann, K., Ed., Academic Press, London, 1991, 47-70.

3. Lehn, J.-M. Supramolecular Chemistry. VCH, Ed. Weinheim, 1995.

4. Kadin, S.B. US patent 4,730,004 1988. (CA 110, P23729y)

5. http://www.jmcs.org.mx, accessed in January, 2005

6. Sheldrick, G. M. SHELXL-93. Program for Crystal Structure Refinement. University of Göttingen, Germany. 1993.

Journal abbreviations, technical terms and nomenclature should be those used by Chemical Abstracts. Figures and tables must not be included in the body of the text. Tables and figures with their respective legends, each on an individual page, should be added after references.

The galley proofs of the accepted paper in PDF format will be sent to the author who submitted the script. Corrected galley proofs should be returned preferably within $48 \mathrm{hrs}$. by e-mail.

For more information, write to: editor.jmcs@gmail.com 


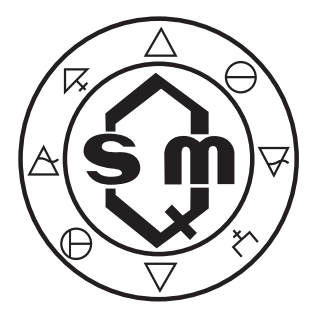

Sociedad Química de México, A.C.

Barranca del Muerto 26, Col. Crédito Constructor, Del. Benito Juárez, C.P. 03940, Mexico City Phone: +5255 56626837; +5255 56626823

Contact: soquimex@sqm.org.mx

www.sqm.org.mx 